Nevada

Environmental

Restoration

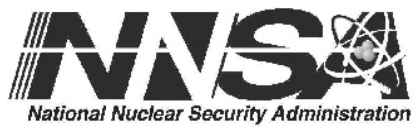

Project

Corrective Action Decision

Document/Corrective Action Plan for the 92-Acre Area and Corrective Action Unit 111: Area 5 WMD Retired Mixed Waste Pits, Nevada National Security Site, Nevada

Controlled Copy No.:

Revision: 1

November 2010

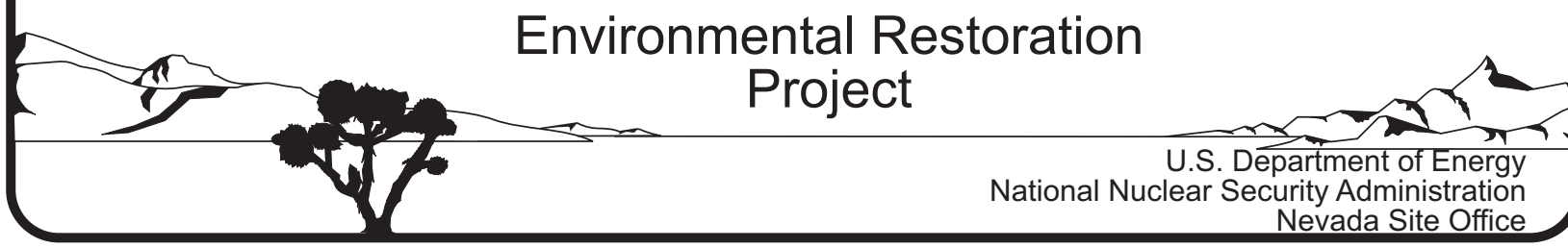




\section{DISCLAIMER}

Reference herein to any specific commercial product, process, or service by trade name, trademark, manufacturer, or otherwise, does not necessarily constitute or imply its endorsement, recommendation, or favoring by the United States Government or any agency thereof.

This report has been reproduced directly from the best available copy.

Available for sale to the public from:

U.S. Department of Commerce

National Technical Information Service

5301 Shawnee Road

Alexandria, VA 22312

Telephone: (800) 553-6847

Fax: (703) 605-6900

E-mail: orders@ntis.gov

Online ordering: http://www.ntis.gov/help/ordermethods.aspx

Available electronically at http://www.osti.gov/bridge.

Available for a processing fee to the U.S. Department of Energy and its contractors, in paper, from:

U.S. Department of Energy

Office of Scientific and Technical Information

P.O. Box 62

Oak Ridge, TN 37831-0062

Telephone: (865) 576-8401

Fax: (865) 576-5728

E-mail: reports@adonis.osti.gov 


\title{
CORRECTIVE ACTION DECISION DOCUMENT/CORRECTIVE ACTION PLAN \\ FOR THE 92-ACRE AREA AND CORRECTIVE ACTION UNIT 111: \\ AREA 5 WMD RETIRED MIXED WASTE PITS, NEVADA NATIONAL SECURITY SITE, NEVADA
}

\author{
U.S. Department of Energy \\ National Nuclear Security Administration \\ Nevada Site Office \\ Las Vegas, Nevada
}

Controlled Copy No.

Revision: 1

November 2010 
THIS PAGE INTENTIONALLY LEFT BLANK 


\section{CORRECTIVE ACTION DECISION DOCUMENT/CORRECTIVE ACTION PLAN FOR THE 92-ACRE AREA AND CORRECTIVE ACTION UNIT 111: AREA 5 WMD RETIRED MIXED WASTE PITS, NEVADA NATIONAL SECURITY SITE, NEVADA}

\section{Approved By: \\ /s/: James J. Cebe for Jhon T. Carilli \\ FoRThon T. Carilli
Federal Sub-Project Director
LLW Sub-Project}


THIS PAGE INTENTIONALLY LEFT BLANK 


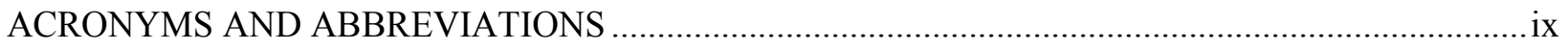

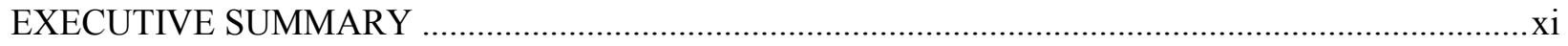

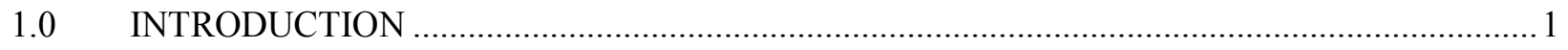

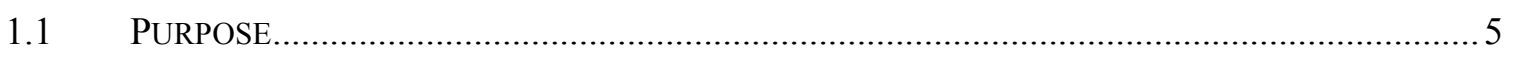

1.2 SCOPE

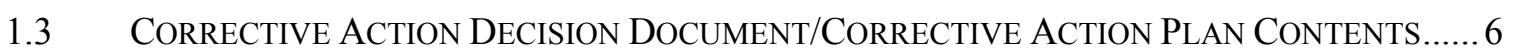

2.0 CORRECTIVE ACTION INVESTIGATION SUMMARY ...................................................

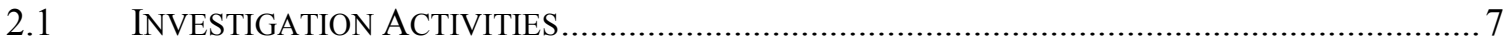

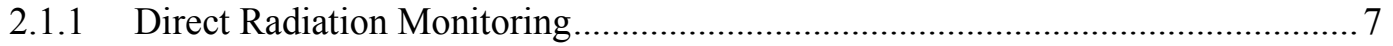

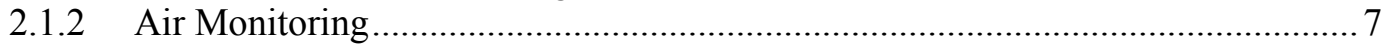

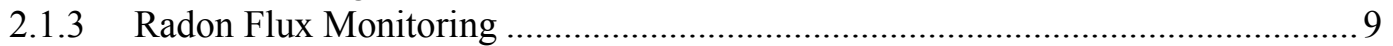

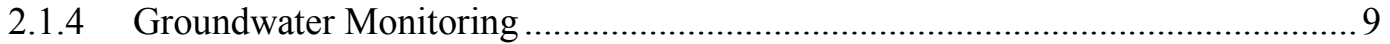

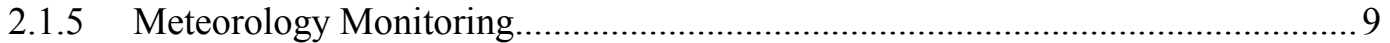

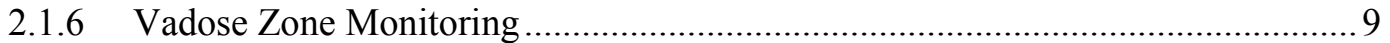

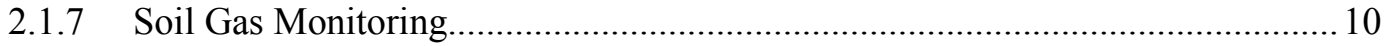

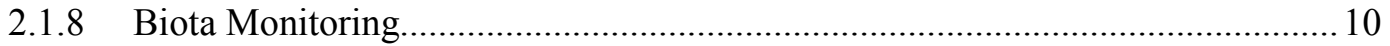

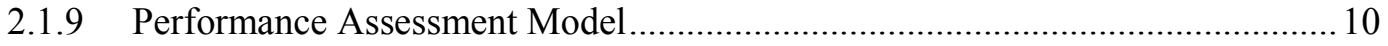

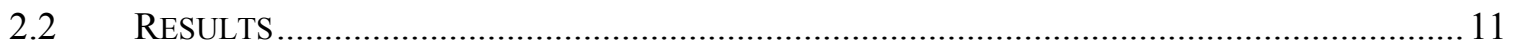

2.2.1 Summary of Characterization and Monitoring Data.......................................... 11

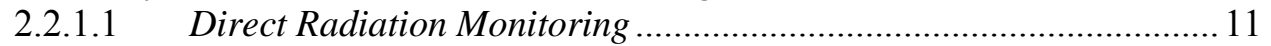

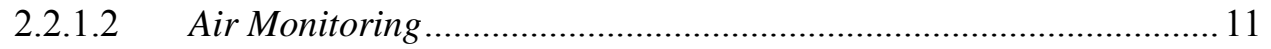

2.2.1.3 Radon Flux Monitoring ............................................................... 11

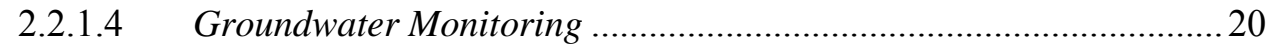

2.2.1.5 Meteorology Monitoring............................................................ 20

2.2.1.6 Vadose Zone Monitoring ................................................................. 32

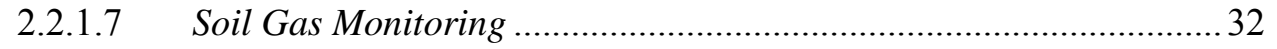

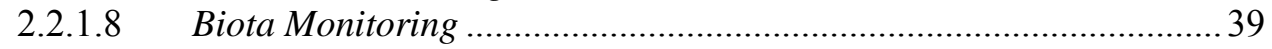

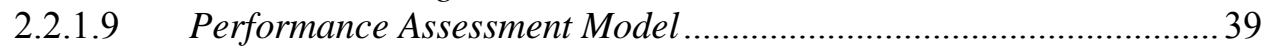

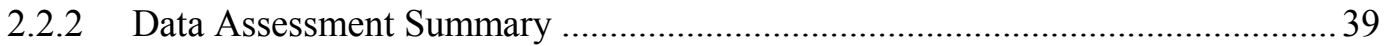

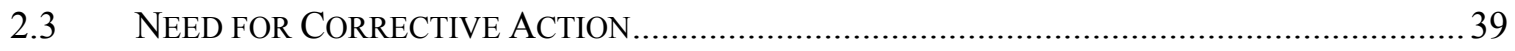

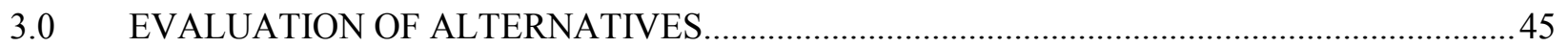

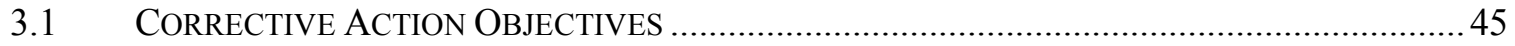

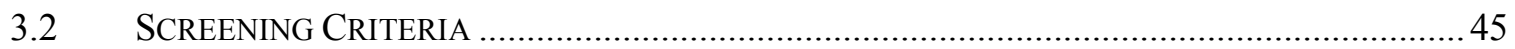

3.2.1 Corrective Action Standards ............................................................................. 46

3.2.1.1 Protection of Human Health and the Environment ........................... 46

3.2.1.2 Compliance with Media Cleanup Standards .......................................... 46

3.2.1.3 Control of the Source(s) of the Release ............................................... 46

3.2.1.4 Compliance with Applicable Federal, State, and Local Standards for

Waste Management ......................................................................... 46

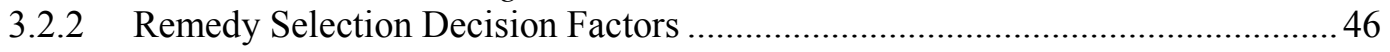

3.2.2.1 Short-Term Reliability and Effectiveness ....................................... 46

3.2.2.2 Reduction of Toxicity, Mobility, and/or Volume............................... 46

3.2.2.3 Long-Term Reliability and Effectiveness....................................... 47

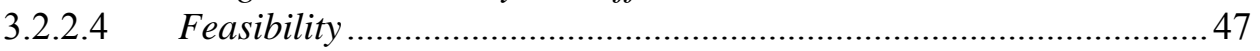

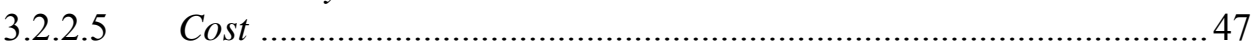

3.3 DEVELOPMENT OF CORRECTIVE ACTION ALTERNATIVES ........................................... 47 


\section{TABLE OF CONTENTS (continued)}

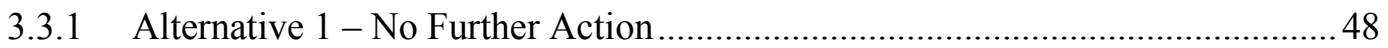

3.3.2 Alternative 2 - Clean Closure.......................................................................... 48

3.3.3 Alternative 3 - Closure in Place with Administrative Controls........................... 48

3.3.4 Alternative 4-Closure in Place with Administrative Controls with Removal of

TRU Waste from Trench T04A ......................................................................... 48

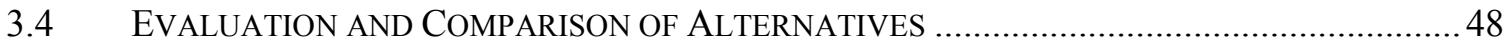

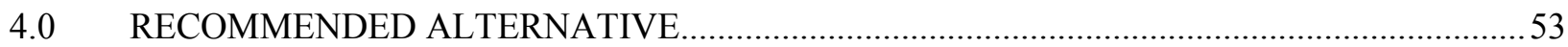

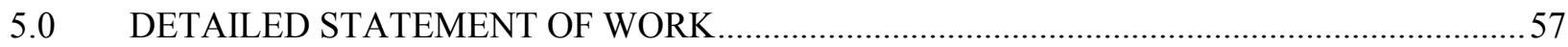

5.1 PREFERRED CORRECTIVE ACTION ALTERNATIVE ......................................................... 57

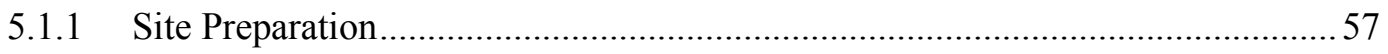

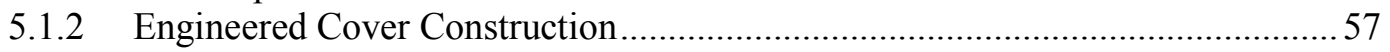

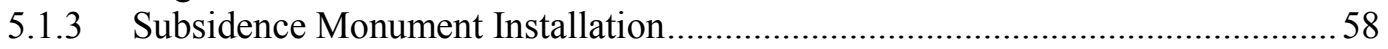

5.1.4 Temporary Erosion and Sediment Control and Vegetation Establishment ..........58

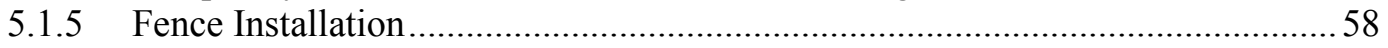

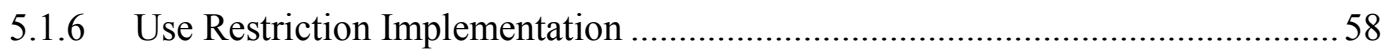

5.2 CONSTRUCTION QUALITY ASSURANCE/QUALITY CONTROL ............................................5

5.2.1 Construction Field Sample Collection Activities ............................................. 59

5.2.2 Construction Quality Assurance/Laboratory Tests ............................................. 59

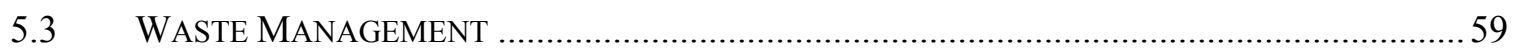

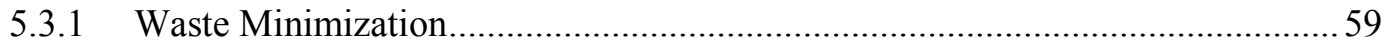

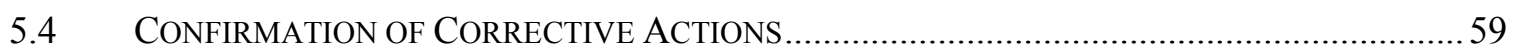

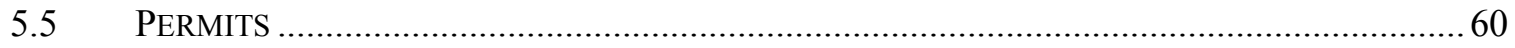

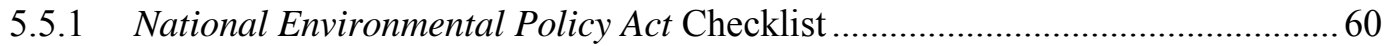

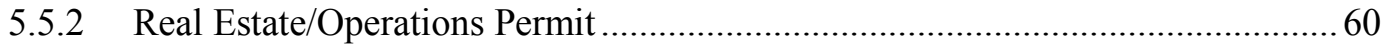

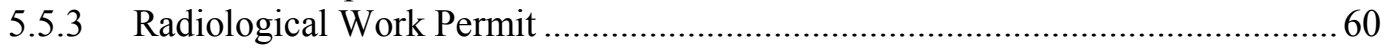

5.5.4 Utility Clearances, Excavation Permits, and Blind Penetration Permits ..............60 60

5.5.5 Resource Conservation and Recovery Act Permit ............................................... 60

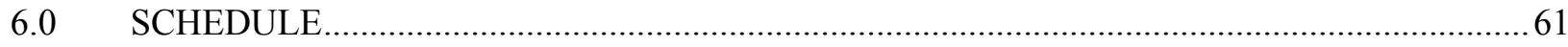

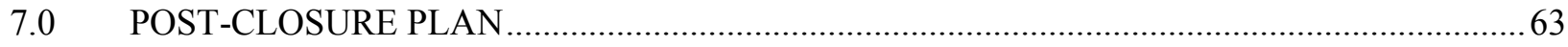

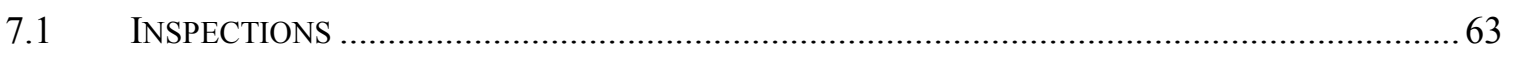

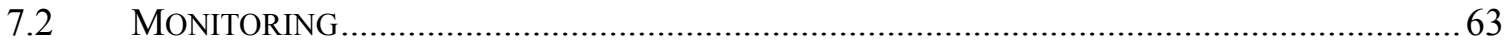

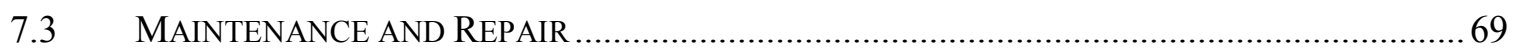

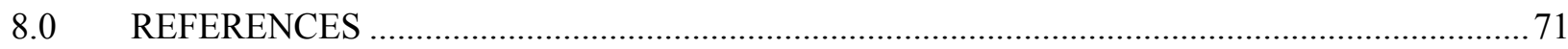

\section{LIBRARY DISTRIBUTION LIST}

\section{LIST OF FIGURES}

Figure 1. Area 5 Radioactive Waste Management Site Location Map............................ 2

Figure 2. 92-ACRE AREA DisPosal Units AND MONITORING NETWORK................................... 3

Figure 3. PATHWAYS TO RECEPTORS FOR THE 92-ACRE AREA ............................................... 13

Figure 4. DiRECT RADIATION MONITORING RESUltS ..................................................... 14

Figure 5. Tritium Air MONITORING RESUltS ................................................................ 15

Figure 6. AMERICIUM-241 AIR MONITORING RESUltS IN 2007 ............................................. 16 


\section{TABLE OF CONTENTS (continued)}

Figure 7. Plutonium-238 Air Monitoring ReSUlts In 2007 .............................................. 17

Figure 8. Plutonium-239/240 Air Monitoring ReSUlts In 2007 ........................................ 18

FigURE 9. RADON FLUX MONITORING RESULTS ..................................................................... 19

Figure 10. GroundWATER ELEVATION RESULTS......................................................... 21

Figure 11. MEASUREd PH Groundwater Monitoring RESUltS .......................................... 22

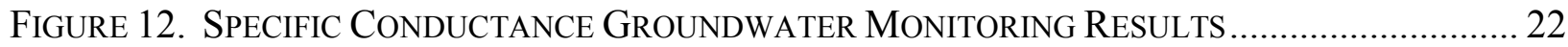

Figure 13. Total Organic Carbon Groundwater Monitoring Results .......................... 23

Figure 14. Total Organic Halides Groundwater Monitoring Results ......................... 23

FIGURE 15. TRITIUM GROUNDWATER MONITORING RESULTS ................................................ 24

Figure 16. DAILY MAXIMUM AND Minimum AIR TEMPERATURE IN 2007 ............................... 25

Figure 17. DaIly AVERAge Relative HuMidity IN 2007 .................................................. 26

Figure 18. DaIly Average Barometric Pressure IN 2007 .............................................. 27

Figure 19. DaIly MaXimum AND AVERAgE Wind SPEED In 2007 ...................................... 28

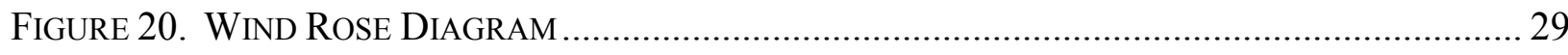

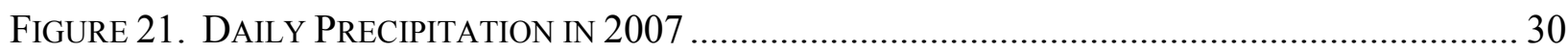

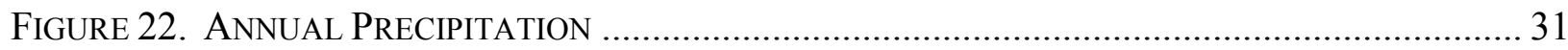

Figure 23. VAdose Zone Monitoring Results At the Weighing Lysimeters.................... 33

Figure 24. VAdose Zone Monitoring Results In the FloOR OF Pit 5 ................................ 34

Figure 25. VAdOSE ZONE MONITORING RESUlts IN THE OPERATIONAL COVER OF Pit 3

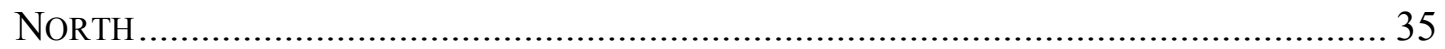

Figure 26. VAdose Zone Monitoring Results in the Operational Cover of Pit 3

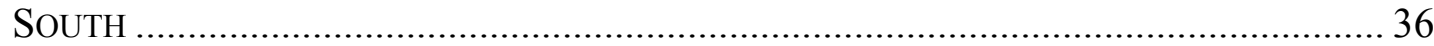

Figure 27. VAdose Zone Monitoring Results in the Operational COVER of Pit 5 ........... 37

FIGURE 28. SOIL GAS MONITORING RESUltS ..................................................................... 38

Figure 29. Small Mammal AND Ant Burrowing Activity IN 2007 .................................. 40

Figure 30. BIOTA MONITORING RESUlTS FOR TRITIUM IN 2007 ........................................ 41

Figure 31. Historical Plant MONITORING RESUltS FOR TRITIUM ....................................... 42

Figure 32. HistoricAl ANIMAL MONITORING RESUltS FOR TRITIUM .................................... 43

Figure 33. PERformance AsSESSMENT Model ReSUltS ...................................................... 44

Figure 34. Collective DoSE VERSUS COVER THICKNESS.................................................... 55

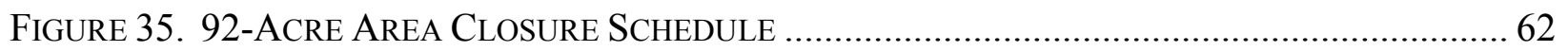

Figure 36. CURREnT AND Proposed VAdose Zone Monitoring LocAtions......................... 68

\section{LIST OF TABLES}

TABle 1. Summary of CurRent Monitoring AT THE Area 5 RWMS ................................... 8

TABLE 2. 92-ACRE AREA EXPOSURE SCENARIOS................................................................ 12

Table 3. Evaluation of General Corrective Action Standards .................................. 49

TABle 4. Evaluation of Remedy SElection Decision FaCtORS......................................... 51 


\section{TABLE OF CONTENTS (continued)}

Table 5. Post-Closure Requirements And Compliance CRITERia For the 92-ACRE AREA 64

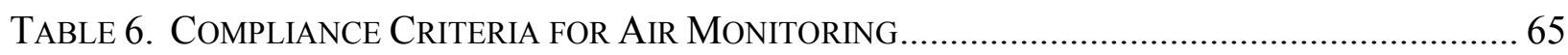

TABLE 7. LIMITATIONS FOR GROUNDWATER INDICATOR PARAMETERS. 65

TABle 8. Progressive APPROACH FOr VAdose Zone Monitoring FOR THE 92-ACre AREA .. 67

\section{LIST OF APPENDICES}

ApPendix A. DATa Quality OBJectives

APPENDIX B. COST ESTIMATES

APPENDIX C. ENGINEERING SPECIFICATIONS AND DRAWINGS

APPENDix D. PROJECT Organization

APPENDIX E. CORRECTIVE ACTION INVESTIGATION RESUlTS

APPENDIX F. DATA ASSESSMENT

APPENDIX G. EVALUATION OF RisK

APPENDIX H. SAMPLING AND ANALYSIS PLAN

APPENDiX I. REVEGETATION PlAN FOR THE 92-ACRE AREA 


\section{ACRONYMS AND ABBREVIATIONS}

\begin{tabular}{ll} 
ALARA & as low as reasonably achievable \\
ASTM & American Society for Testing and Materials \\
BN & Bechtel Nevada \\
${ }^{\circ} \mathrm{C}$ & degree(s) Celsius \\
CAA & corrective action alternative \\
CADD/CAP & Corrective Action Decision Document/Corrective Action Plan \\
CAU & Corrective Action Unit \\
CFR & Code of Federal Regulations \\
CQA & construction quality assurance \\
$\mathrm{cm}$ & centimeter(s) \\
$\mathrm{CSM}$ & conceptual site model \\
$\mathrm{DCG}$ & Derived Concentration Guide \\
$\mathrm{DOE}$ & U.S. Department of Energy \\
$\mathrm{DQI}$ & Data Quality Indicator \\
$\mathrm{DQO}$ & Data Quality Objective \\
$\mathrm{EPA}$ & U.S. Environmental Protection Agency \\
$\mathrm{FFACO}$ & Federal Facility Agreement and Consent Order \\
$\mathrm{GCD}$ & Greater Confinement Disposal \\
$\mathrm{IL}$ & investigation level \\
$\mathrm{kPa}$ & kilopascal(s) \\
$\mu \mathrm{Ci} / \mathrm{m}^{3}$ & microcurie(s) per cubic meter \\
$\mu \mathrm{g} / \mathrm{L}$ & microgram(s) per liter \\
$\mathrm{m}$ & meter(s) \\
$\mathrm{m} / \mathrm{s}$ & meter(s) per second \\
$\mathrm{MDC}$ & minimum detectable concentration \\
$\mathrm{mg} / \mathrm{L}$ & milligram(s) per liter \\
$\mathrm{mm}$ & millimeter(s) \\
$\mathrm{mmhos} / \mathrm{cm}$ & millimho(s) per centimeter \\
$\mathrm{mR} / \mathrm{day}$ & milliroentgen(s) per day \\
$\mathrm{mrem} / \mathrm{yr}$ & millirem(s) per year \\
$\mathrm{MWDU}$ & Mixed Waste Disposal Unit \\
\hline
\end{tabular}




\section{ACRONYMS AND ABBREVIATIONS (continued)}

NAC

NDEP

NEPA

NNSA/NSO

$\mathrm{NNSA} / \mathrm{NV}$

NSTec

NNSS

$\mathrm{O}$

$\mathrm{pCi} / \mathrm{L}$

$\mathrm{pCi} / \mathrm{m}^{2} \mathrm{~s}$

$\mathrm{pCi} / \mathrm{m}^{3}$

per-Sv

QA

$\mathrm{QC}$

RCRA

REOP

RWMS

RWP

TCLP

TDR

TLD

TRU

UR
Nevada Administrative Code

Nevada Division of Environmental Protection

National Environmental Policy Act

U.S. Department of Energy, National Nuclear Security Administration Nevada Site Office

U.S. Department of Energy, National Nuclear Security Administration Nevada Operations Office

National Security Technologies, LLC

Nevada National Security Site

Order

picocurie(s) per liter

picocurie(s) per square meter per second

picocurie(s) per cubic meter

person-Sievert(s)

quality assurance

quality control

Resource Conservation and Recovery Act

Real Estate/Operations Permit

Radioactive Waste Management Site

Radiological Work Permit

Toxicity Characterization Leaching Procedure

time-domain reflectometry

thermoluminescent dosimeter

transuranic

use restriction 


\section{EXECUTIVE SUMMARY}

This Corrective Action Decision Document/Corrective Action Plan (CADD/CAP) has been prepared for the 92-Acre Area, the southeast quadrant of the Radioactive Waste Management Site, located in Area 5 of the Nevada National Security Site (NNSS). The 92-Acre Area includes Corrective Action Unit (CAU) 111, "Area 5 WMD Retired Mixed Waste Pits."

Data Quality Objectives (DQOs) were developed for the 92-Acre Area, which includes CAU 111. The result of the DQO process was that the 92-Acre Area is sufficiently characterized to provide the input data necessary to evaluate corrective action alternatives (CAAs) without the collection of additional data. The DQOs are included as Appendix A of this document.

This CADD/CAP identifies and provides the rationale for the recommended CAA for the 92-Acre Area, provides the plan for implementing the CAA, and details the post-closure plan.

When approved, this CADD/CAP will supersede the existing Pit 3 (P03) Closure Plan, which was developed in accordance with Title 40 Code of Federal Regulations (CFR) Part 265, "Interim Status Standards for Owners and Operators of Hazardous Waste Treatment, Storage, and Disposal Facilities." This document will also serve as the Closure Plan and the Post-Closure Plan, which are required by 40 CFR 265, for the 92-Acre Area. After closure activities are complete, a request for the modification of the Resource Conservation and Recovery Act Permit that governs waste management activities at the NNSS will be submitted to the Nevada Division of Environmental Protection to incorporate the requirements for post-closure monitoring.

Four CAAs, ranging from No Further Action to Clean Closure, were evaluated for the 92-Acre Area. The CAAs were evaluated on technical merit focusing on performance, reliability, feasibility, safety, and cost. Based on the evaluation of the data used to develop the conceptual site model; a review of past, current, and future operations at the site; and the detailed and comparative analysis of the potential CAAs, Closure in Place with Administrative Controls is the preferred CAA for the 92-Acre Area.

Closure activities will include the following:

- Constructing an engineered evapotranspiration cover over the 92-Acre Area

- Installing use restriction (UR) warning signs, concrete monuments, and subsidence survey monuments

- Establishing vegetation on the cover

- Implementing a UR

- Implementing post-closure inspections and monitoring

The Closure in Place with Administrative Controls alternative meets all requirements for the technical components evaluated, fulfills all applicable federal and state regulations for closure of the site, and will minimize potential future exposure pathways to the buried waste at the site. 
92-Acre Area and CAU 111 CADD/CAP

Section: Executive Summary

Revision: 1

Date: November 2010

THIS PAGE INTENTIONALLY LEFT BLANK 


\subsection{INTRODUCTION}

This Corrective Action Decision Document/Corrective Action Plan (CADD/CAP) has been prepared for the 92-Acre Area. The 92-Acre Area constitutes the southeast quadrant of the Radioactive Waste Management Site (RWMS), located in Area 5 of the Nevada National Security Site (NNSS) (Figures 1 and 2).

The Area 5 RWMS uses engineered shallow-land burial cells to dispose of packaged waste. The 92-Acre Area contains 13 Greater Confinement Disposal (GCD) boreholes, 16 narrow trenches, and 9 broader pits. With the exception of three active pits (P03, P06, and P09), all trenches and pits in the 92-Acre Area currently have operational covers approximately 2.4 meters $(\mathrm{m})$ thick.

The units within the 92-Acre Area are grouped into the following six informal categories based on physical location, waste types, and regulatory requirements (Figure 2):

- $\quad$ Pit 3 Mixed Waste Disposal Unit (MWDU)

- Corrective Action Unit (CAU) 111

- CAU 207

- Low-level waste disposal units

- Asbestiform low-level waste disposal units

- One transuranic (TRU) waste trench (where 1.2 kilograms [2.6 pounds, or approximately 61.5 cubic centimeters] of TRU waste was inadvertently disposed)

Pit 3 MWDU, an active pit with a closure date of 2011, is governed by Resource Conservation and Recovery Act (RCRA) Permit NEV HW0021 (Nevada Division of Environmental Protection [NDEP], 2005). As such, Pit 3 must be closed in accordance with Title 40 Code of Federal Regulations (CFR) 265, "Interim Status Standards for Owners and Operators of Hazardous Waste Treatment, Storage, and Disposal Facilities" (CFR, 2006d), as adopted by Nevada Administrative Code (NAC) 444.8632, "Compliance with Federal Regulations Adopted by Reference" (NAC, 2006).

CAU 111, “Area 5 WMD Retired Mixed Waste Pits," which includes disposal units where mixed waste may have been placed prior to the implementation of RCRA, is listed in the Federal Facility Agreement and Consent Order (FFACO). The FFACO is a legally binding document that, by agreement, supersedes the corrective action requirements of RCRA (FFACO, 1996; as amended February 2008).

CAU 207, “Archived - Area 5 WMD Greater Confinement Disposal (GCD) Boreholes,” consists of GCD boreholes containing TRU waste. CAU 207 was previously removed from the purview of the FFACO and archived.

As agreed by NDEP and the U.S. Department of Energy, National Nuclear Security Administration Nevada Site Office (NNSA/NSO) on February 14, 2008, the entire 92-Acre Area will be closed under the FFACO. This document follows the approved FFACO template for a CADD/CAP. The FFACO process not only meets all the requirements of RCRA (CFR, 2006d), it also includes development of a conceptual site model (CSM), data quality objectives (DQOs), and a detailed analysis and comparison of corrective action alternatives (CAAs). 
Date: November 2010

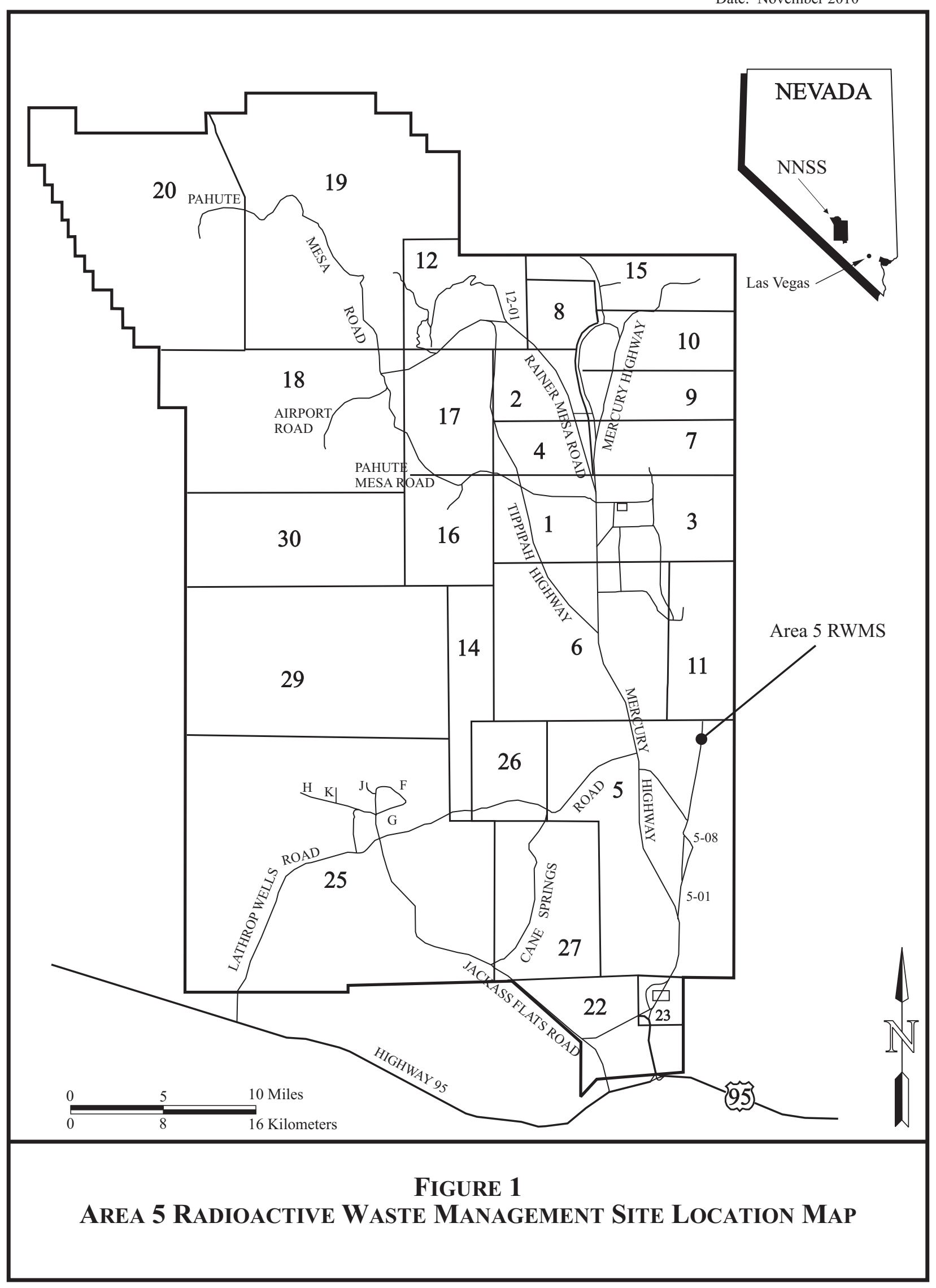




\section{Explanation}

Air Particulate and Tritium Station

Groundwater Well

\$ Meteorology Station

$\otimes \quad$ Rain Gauge

$\boldsymbol{\nabla}$ Weighing Lysimeter

- Vadose Zone Station

$\checkmark$ Soil Gas Monitoring Station

D Thermoluminescent Dosimeter

- - 92-Acre Area Boundary

-.. Area 5 RWMS Boundary

$\square$ Low-Level Waste Unit

Asbestiform Low-Level Waste Unit

$\square$ Transuranic Waste Trench

Corrective Action Unit 111

Pit 3 Mixed Waste Disposal Unit

- Borehole with Waste

- Empty Borehole

- Borehole with Transuranic Waste (Corrective Action Unit 207)

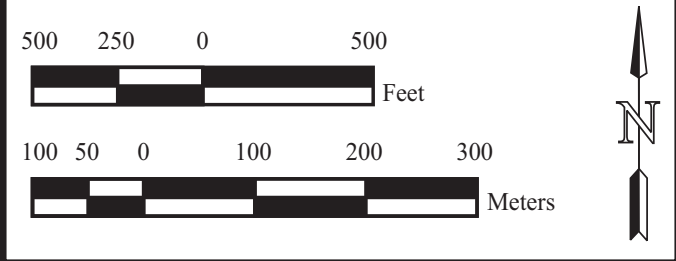


THIS PAGE INTENTIONALLY LEFT BLANK 
Site characterization that began in the 1990s, modeling results, and waste inventories provide the data necessary to develop a CSM. The results of four assessments show that disposal operations are in compliance with U.S. Department of Energy (DOE) regulations and provide assurance that the public and the environment will be protected for 1,000 years under DOE Order (O) 435.1, "Radioactive Waste Management" (DOE, 1999) and for 10,000 years concerning TRU waste under 40 CFR 191, "Environmental Radiation Protection Standards for Management and Disposal of Spent Nuclear Fuel, High-Level and Transuranic Radioactive Wastes" (CFR, 2006b).

A detailed discussion of the site history and characteristics, compliance assessments, waste inventory and uncertainty, and ongoing monitoring activities is presented in the DQOs, which are included as Appendix A of this document. The result of the DQO process was that the 92-Acre Area is sufficiently characterized to provide the input data necessary to evaluate CAAs without collecting additional data.

\subsection{Purpose}

This CADD/CAP develops and evaluates potential CAAs and provides the rationale for the selection of the recommended CAA for the 92-Acre Area. This document also provides the plan for implementing the preferred CAA, presents the scope of work, and details the post-closure plan. The post-closure plan includes a progressive monitoring approach to address future monitoring. The progressive monitoring approach will provide a protective and cost-effective method to monitor and address potential contaminant migration in the future (See Section 7.0).

When approved, this CADD/CAP will supersede the existing Pit 3 Closure Plan, which was developed in accordance with 40 CFR 265. This document will also serve as the Closure Plan and Post-Closure Plan for the 92-Acre Area, which are required by 40 CFR 265. After completing closure activities, a request for modification of RCRA Permit NEV HW0021, to incorporate requirements for post-closure monitoring, will be submitted to NDEP (NDEP, 2005).

\subsection{SCOPE}

The scope of activities used to identify, evaluate, and recommend CAAs included the following:

- Evaluating corrective action objectives based on the DQOs and CAA screening criteria

- Recommending and justifying the preferred CAA

CAAs were evaluated for the 92-Acre Area on technical merit based on performance, reliability, feasibility, safety, and cost. Based on the evaluation of the data used to develop the CSM; a review of past, current, and future operations at the site; and the detailed and comparative analysis of the potential CAAs, Closure in Place with Administrative Controls is the preferred CAA for the 92-Acre Area. Closure activities will include the following:

- Constructing an engineered evapotranspiration cover over the 92-Acre Area

- Installing use restriction (UR) warning signs, concrete monuments, and subsidence survey monuments

- Establishing vegetation on the cover

- Implementing a UR

- Implementing post-closure inspections and monitoring 
The Closure in Place with Administrative Controls alternative meets all requirements for the technical components evaluated, fulfills all applicable federal and state regulations, and minimizes potential future exposure pathways to the buried waste. Of the CAAs evaluated based on short-term reliability and effectiveness; reduction of toxicity, mobility, and/or volume; long-term reliability and effectiveness; feasibility; and cost, the Closure in Place with Administrative Controls alternative received the highest score and therefore will have the most desirable overall impact on these factors.

\subsection{Corrective Action Decision Document/Corrective Action Plan CONTENTS}

This CADD/CAP consists of the following sections and appendices:

- Section 1.0 - Introduction: Summarizes this document's purpose, scope, and contents

- Section 2.0 - Corrective Action Investigation Summary: Summarizes investigation activities, results of the investigation, and the need for corrective action

- Section 3.0 - Evaluation of Alternatives: Describes, identifies, and evaluates the steps taken to determine the preferred CAA

- Section 4.0 - Recommended Alternative: Presents the preferred CAA and the rationale based on the corrective action objectives and screening criteria

- Section 5.0 - Detailed Statement of Work: Provides a description of the preferred CAA its planned implementation, identifies quality assurance (QA) and quality control (QC) activities, provides a summary of waste management, identifies activities to verify the objectives of the corrective actions, and identifies permits needed to implement the CAA

- Section 6.0 - Schedule: Identifies the schedule for major activities

- Section 7.0 - Post-Closure Plan: Describes the requirements for post-closure inspections, monitoring, maintenance, and repairs

- Section 8.0-References: Provides a list of all referenced documents in this report

- Appendix A - Data Quality Objectives: Provides the DQOs, as presented to and approved by NDEP

- Appendix B - Cost Estimates: Presents cost estimates for each CAA

- Appendix C - Engineering Specifications and Drawings: Includes engineering specifications and drawings for the 92-Acre Area

- Appendix D - Project Organization: Identifies the NNSA/NSO Sub-Project Director and other appropriate personnel involved with characterization and closure activities

- Appendix E - Corrective Action Investigation Results: Not applicable

- Appendix F - Data Assessment: Not applicable

- Appendix G - Evaluation of Risk: Not applicable

- Appendix H - Sampling and Analysis Plan: Not applicable

- Appendix I - Revegetation Plan for the 92-Acre Area: Provides details on how vegetation will be established on the cover. 


\subsection{CORRECTIVE ACTION INVESTIGATION SUMMARY}

The following sections summarize site characterization, modeling, and monitoring activities, and identify the need for corrective action for the 92-Acre Area.

\subsection{INVESTIGATION ACTIVITIES}

Site characterization activities at the Area 5 RWMS began in the early 1990s. Four assessments demonstrate that waste disposal operations are in compliance with federal regulations and provide assurance that members of the public and the environment will be protected after closure for 1,000 years under DOE O 435.1 (DOE, 1999) and for 10,000 years concerning TRU waste under 40 CFR 191 (CFR, 2006b). These assessments are summarized in the DQOs provided in Appendix A. The current monitoring network is summarized in Table 1 and shown in Figure 2 on Page 3 of this document. The following sections discuss monitoring and modeling results.

\subsubsection{Direct Radiation Monitoring}

To assess external radiation, measure gamma radiation levels, and detect changes, direct radiation monitoring is conducted with thermoluminescent dosimeters (TLDs) at 12 locations shown in Figure 2. TLDs measure ionizing radiation exposure from all sources, including natural and man-made radioactivity, and results represent the potential external dose to a hypothetical person residing at the Area 5 RWMS. At each location, a pair of TLDs is placed at $1 \mathrm{~m}$ above ground surface. The TLDs are exchanged for analysis on a quarterly basis, and analysis is conducted with automated TLD readers. Since monitoring began in 1998, exposure rate measurements have generally fallen within the range of background measurements collected at locations across the NNSS and indicate that a member of the public will not receive a dose greater than 25 millirems per year (mrem/yr), even if they were to reside at the Area 5 RWMS. The highest measurement recorded was 0.6 milliroentgens per day (mR/day) in 2004 .

\subsubsection{Air Monitoring}

Air monitoring of tritium and radioactive particulates is conducted at two locations downwind of the Area 5 RWMS. Tritium is monitored because it is a highly mobile radioactive isotope and is an indicator of volatile radionuclide migration from waste cells into the atmosphere.

Atmospheric moisture is continuously collected using molecular sieve columns, and samples are analyzed every 2 weeks for tritium by liquid scintillation counting. Tritium concentrations in air have been well below the DOE Derived Concentration Guide (DCG) of 100,000 picocuries per cubic meter $\left(\mathrm{pCi} / \mathrm{m}^{3}\right)$ for tritium. The DCG is the concentration of a radionuclide in air that, if inhaled for 1 year, would result in the DOE radiation limit of $100 \mathrm{mrem} / \mathrm{yr}$ committed dose equivalent to the public. The highest measurement recorded was $47.4 \mathrm{pCi} / \mathrm{m}^{3}$ in 2006 .

Air particulates are collected on glass fiber filters, which are screened weekly for gross alpha and beta radioactivity to detect changes in airborne radioactivity. Monthly composites of the weekly samples are analyzed by gamma spectroscopy for gamma-emitting radionuclides and by radiochemical analysis for americium and plutonium. Americium and plutonium concentrations in air have been well below the respective DCGs of 0.02 and $0.03 \mathrm{pCi} / \mathrm{m}^{3}$. In 2007, the highest measurement recorded for americium was $0.00000595 \mathrm{pCi} / \mathrm{m}^{3}$, and the highest measurement recorded for plutonium was $0.0000321 \mathrm{pCi} / \mathrm{m}^{3}$. 


\section{TABle 1. Summary of CurRent Monitoring at The Area 5 RWMS}

\begin{tabular}{|c|c|c|}
\hline ELEMENT & BRIEF DESCRIPTION & SUMMARY OF RESULTS \\
\hline $\begin{array}{l}\text { Direct Radiation } \\
\text { Monitoring }\end{array}$ & TLDs at 12 locations & $\begin{array}{l}\text { Typical exposure rate measurements are } \\
\text { at background levels. }\end{array}$ \\
\hline Air Monitoring & $\begin{array}{l}\text { - Atmospheric moisture analysis for } \\
\text { tritium at two locations every two weeks } \\
\text { - Air particulates (americium and } \\
\text { plutonium) sampled at two locations } \\
\text { (weekly screening and monthly } \\
\text { laboratory analysis) }\end{array}$ & $\begin{array}{l}\text { - Tritium concentrations in air are } \\
\text { below the DCG. } \\
\text { - Particulate concentrations are below } \\
\text { the DCGs. }\end{array}$ \\
\hline $\begin{array}{l}\text { Radon Flux } \\
\text { Monitoring }\end{array}$ & $\begin{array}{l}\text { Collected at various locations around the } \\
\text { Area } 5 \text { RWMS }\end{array}$ & $\begin{array}{l}\text { Radon fluxes are well below the } \\
\text { regulatory limit. }\end{array}$ \\
\hline $\begin{array}{l}\text { Groundwater } \\
\text { Monitoring }\end{array}$ & $\begin{array}{l}\text { Monitoring at three wells: } \\
\text { - Water levels every } 3 \text { months } \\
\text { - Samples for contamination indicators and } \\
\text { water chemistry parameters every } 6 \\
\text { months }\end{array}$ & $\begin{array}{l}\text { - The water table is essentially flat (i.e., } \\
\text { little or no gradient). } \\
\text { - There has been no measurable impact } \\
\text { to the uppermost aquifer. }\end{array}$ \\
\hline $\begin{array}{l}\text { Meteorology } \\
\text { Monitoring }\end{array}$ & $\begin{array}{l}\text { - Precipitation } \\
\text { - Air temperature } \\
\text { - Relative humidity } \\
\text { - Wind speed and direction } \\
\text { - Barometric pressure }\end{array}$ & $\begin{array}{l}\text { - Average annual rainfall is } 131 \mathrm{~mm} \text {. } \\
\text { - Average annual temperature is } 16^{\circ} \mathrm{C} \text {. } \\
\text { - Average humidity is } 30 \text { percent. } \\
\text { - Average wind speed is } 2.7 \mathrm{~m} / \mathrm{s} \text {. } \\
\text { - Average pressure is } 90.5 \mathrm{kPa} \text {. }\end{array}$ \\
\hline $\begin{array}{l}\text { Vadose Zone } \\
\text { Monitoring }\end{array}$ & $\begin{array}{l}\text { - TDR probes measure the volumetric } \\
\text { moisture content of the soil in three } \\
\text { operational covers } \\
\text { - TDR probes measure the volumetric } \\
\text { moisture content of the soil in one waste } \\
\text { disposal unit floor } \\
\text { - Two weighing lysimeters (vegetated and } \\
\text { bare) provide information for the water } \\
\text { balance of the soil }\end{array}$ & $\begin{array}{l}\text { - Volumetric moisture content of the } \\
\text { soil in covers continues to indicate dry } \\
\text { conditions. } \\
\text { - Volumetric moisture content of the } \\
\text { soil in the floor of Pit } 5 \text { (P05) } \\
\text { indicates no infiltration. } \\
\text { - Vegetation and the arid climate } \\
\text { prevent infiltration by } \\
\text { evapotranspiration. }\end{array}$ \\
\hline $\begin{array}{l}\text { Soil Gas } \\
\text { Monitoring }\end{array}$ & $\begin{array}{l}\text { Soil gas monitoring for tritium at one } \\
\text { waste cell }\end{array}$ & $\begin{array}{l}\text { Upward migration of tritium through the } \\
\text { soil from the waste is extremely slow. }\end{array}$ \\
\hline $\begin{array}{l}\text { Biota } \\
\text { Monitoring }\end{array}$ & $\begin{array}{l}\text { Biota (plant and animal) samples collected } \\
\text { at an approximate 2-year interval }\end{array}$ & $\begin{array}{l}\text { Biota monitoring results show tritium } \\
\text { uptake. }\end{array}$ \\
\hline
\end{tabular}

${ }^{\circ} \mathrm{C}$ : degree(s) Celsius

DCG: Derived Concentration Guide

$\mathrm{kPa}$ : kilopascal(s)

$\mathrm{mm}$ : millimeter(s)

$\mathrm{m} / \mathrm{s}:$ meter(s) per second

TDR: time-domain reflectometry

TLD: thermoluminescent dosimeter 


\subsubsection{Radon Flux Monitoring}

Radon flux measurements have been collected since 2000 at various locations to meet the performance objective of DOE O 435.1 and assess whether radon levels exceed the regulatory limit. Measurements are collected once a year at one or two locations that are most likely to have elevated results based on radon and thorium-bearing waste. Radon flux domes placed on the ground surface collect the measurements. The highest measured radon flux was 4 picocuries per square meter per second $\left(\mathrm{pCi} / \mathrm{m}^{2} \mathrm{~s}\right)$ in 2004 , well below the regulatory limit of $20 \mathrm{pCi} / \mathrm{m}^{2} \mathrm{~s}$.

\subsubsection{Groundwater Monitoring}

Groundwater monitoring has been conducted since 1993 at three wells shown in Figure 2. Water levels in each well are measured every 3 months, and water samples are collected every 6 months. Based on groundwater elevations, the water table under the Area 5 RWMS is essentially flat. Calculated groundwater flow velocities are approximately $0.1 \mathrm{~m}$ per year. Water samples are analyzed for indicators of contamination $(\mathrm{pH}$, specific conductance, total organic carbon, total organic halides, and tritium) and general water chemistry parameters (calcium, magnesium, potassium, sodium, iron, manganese, bicarbonate, sulfate, silicate, chloride, and fluoride). Investigation levels (ILs) were established as the compliance criteria for indicators of contamination by NNSA/NSO and NDEP in 1998 (Bechtel Nevada [BN], 1998). Groundwater monitoring data have remained stable and below ILs since monitoring began; therefore, these indicate no measurable impact to the uppermost aquifer from the Area 5 RWMS.

\subsubsection{Meteorology Monitoring}

The Area 5 RWMS is located in a windy, arid climate with high average temperatures and low precipitation rates. Meteorological parameters, including precipitation, solar radiation, air temperature, relative humidity, wind speed and direction, and barometric pressure, are measured at a 3-m meteorology tower near the southeast corner of the Area 5 RWMS to quantify the exchange of water and heat between the soil and the atmosphere. Reference evapotranspiration, the rate at which readily available soil water is vaporized from the surface, is calculated from these meteorological parameters. The ratio of reference evapotranspiration to precipitation is then determined. In 2007, the ratio of reference evapotranspiration to precipitation was 12.9, indicating that the rate of evapotranspiration upwards through the cover far exceeds the rate of infiltration of precipitation downwards toward the waste cells.

\subsubsection{Vadose Zone Monitoring}

Vadose zone monitoring is conducted at three operational covers, one pit floor, and two weighing lysimeters to assess water balance, confirm the key assumption of no downward pathway to groundwater, and evaluate the performance of operational covers. Water balance studies use meteorology data to calculate evapotranspiration, directly measure evapotranspiration and bare-soil evaporation with weighing lysimeters, and measure volumetric moisture content of the soil, soil water potential, and temperature. Data indicate that vegetation and the arid climate prevent precipitation from percolating deep into the soil by returning moisture to the atmosphere by evapotranspiration. Vegetated lysimeter data were used to generate a vadose zone flow model that confirms there is no downward pathway under vegetated conditions. Time-domain reflectometry (TDR) data for the operational covers continue to indicate dry conditions. 


\subsubsection{Soil Gas Monitoring}

Soil gas monitoring for tritium movement has been conducted since 1990 at borehole GCD-05, which has a large tritium inventory (approximately 2.2 million curies at the time of disposal) buried from 20 to $36 \mathrm{~m}$ below ground surface. Two strings of nine probes are buried in the borehole. A depth profile of soil gas tritium concentration is measured from 3 to $36 \mathrm{~m}$ below ground surface to provide a direct measure of changes in tritium activity with depth as a result of degradation of waste containers, advection, and diffusion. During the 18-year measurement period, soil gas tritium concentrations show extremely slow upward movement of tritium through soil from the waste, which indicates that tritium and associated waste remain contained.

\subsubsection{Biota Monitoring}

Bioturbation and plant uptake are two release mechanisms that potentially transport tritium upward through waste covers and into the atmosphere. Plants can transport tritium by root uptake and subsequent evapotranspiration, and animal burrows may potentially intrude into waste; however, root depths of the species in this area are generally less than $2 \mathrm{~m}$, and animal burrows only extend approximately $0.3 \mathrm{~m}$ below ground surface. Biota (plant and animal) samples are collected every 2 years to measure tritium concentrations. Analyses of samples collected at the Area 5 RWMS show detectable levels of tritium. Although these results show tritium uptake, there is no evidence that plants or animals have intruded into the waste, and it is unlikely that plant roots or animal burrows extend to a depth that could impact buried waste.

\subsubsection{Performance Assessment Model}

To evaluate the potential for contamination of environmental media, a model has been developed using GoldSim ${ }^{\circledR}$ software that assesses closure alternatives, optimizes the closure cover design, and demonstrates compliance with federal regulations (Shott et al., 1998; BN, 2006).

Model input parameters are represented by probability distributions to account for uncertainty. Comprehensive sensitivity analyses show that the parameters that have a significant effect on the outcome of the model are related to plant uptake and animal burrowing. Radionuclide inventories do not have a significant effect on the outcome of the model, highlighting the ability of the disposal system to contain waste and protect the public (Shott et al., 1998; BN, 2006).

The following conservative assumptions are accounted for in the model:

- The critical group is a resident farmer $100 \mathrm{~m}$ from the site boundary. This assumption is conservative due to the remote location, arid climate, marginal agricultural soil, lack of resources such as surface water or shallow groundwater, and the presence of nearby nuclear craters that are likely to remind any potential residents of the probable presence of radioactive contamination. In addition, public access to the NNSS is restricted.

- All radionuclides are assumed to be immediately available for release and transport (i.e., all waste containers have failed, and the waste is released directly into the cover soil). This assumption is conservative because containers and waste forms are likely to delay the release of radionuclides for decades if not hundreds of years.

- The critical group, located $100 \mathrm{~m}$ from the site boundary, is assumed to be exposed to the same concentrations of radionuclides that are present on the site itself. This assumption is conservative because $100 \mathrm{~m}$ from the site boundary, the actual concentrations are expected to be orders of magnitude less than onsite concentrations. 


\subsection{RESUlts}

Monitoring results are reported annually in the Nevada Test Site Waste Management Monitoring Report Area 3 and Area 5 Radioactive Waste Management Sites. Groundwater monitoring results are reported annually in the Nevada Test Site Data Report: Groundwater Monitoring Program Area 5 Radioactive Waste Management Site. The following sections provide a summary of the most recent results of monitoring data and modeling activities.

\subsubsection{Summary of Characterization and Monitoring Data}

Extensive site characterization, environmental monitoring, and modeling have been performed for the Area 5 RWMS over the past several decades. These studies and the waste inventory are summarized in the DQOs provided in Appendix A of this document. Release pathways are upwards to the surface with negligible pathway to groundwater. The applicable transport processes are the release of volatile constituents to the cover and the atmosphere, and the migration of contaminants in the cover and to the atmosphere by erosion, animal burrowing/plant uptake, and inadvertent disturbance of waste. Table 2 summarizes the release pathways and associated exposure scenarios. Figure 3 illustrates the pathways to receptors and their applicability to the site.

\subsubsection{Direct Radiation Monitoring}

Quarterly direct radiation exposure data from 1998 to 2007 at the Area 5 RWMS and NNSS background locations are presented in units of $\mathrm{mR} /$ day in Figure 4. The data indicate that direct radiation exposure is generally low or declining (National Security Technologies, LLC [NSTec], 2008).

\subsubsection{Air Monitoring}

Tritium concentrations in air are well below the DCG of $100,000 \mathrm{pCi} / \mathrm{m}^{3}$ for tritium. On December 19, 2005, a puncture was discovered in a shipping container that was being retrieved. This allowed tritium to escape from the container. Although the container was quickly sealed, tritium from the soil surrounding the container was likely the source of slightly elevated levels of tritium through June 2006. Figure 5 shows the tritium air monitoring results since 2005 in $\mathrm{pCi} / \mathrm{m}^{3}$. All measured concentrations of tritium are below the DCG (NSTec, 2008).

Gamma spectroscopy results for americium and plutonium have generally been below the sample-specific minimum detectable concentrations (MDCs). Figure 6, Figure 7, and Figure 8 show the results for americium and plutonium for 2007 in $\mathrm{pCi} / \mathrm{m}^{3}$. All measured concentrations of americium and plutonium are below the DCG for each radionuclide (NSTec, 2008).

\subsubsection{Radon Flux Monitoring}

Radon flux results for 2000 to 2008 are summarized in Figure 9. All radon flux measurements are at least 7 times lower than the regulatory limit of $20 \mathrm{pCi} / \mathrm{m}^{2} \mathrm{~s}$ (NSTec, 2008). 
TABLE 2. 92-ACRE AREA EXPOSURE SCENARIOS

\begin{tabular}{|c|c|c|c|c|c|}
\hline $\begin{array}{c}\text { SOURCE OF } \\
\text { POTENTIAL } \\
\text { CONTAMINATION }\end{array}$ & $\begin{array}{c}\text { RELEASE } \\
\text { MECHANISM }\end{array}$ & $\begin{array}{l}\text { EXPOSURE } \\
\text { PATHWAY }\end{array}$ & $\begin{array}{l}\text { EXPOSURE } \\
\text { ROUTE }\end{array}$ & RECEPTOR & EXPOSURE SCENARIO \\
\hline \multirow{4}{*}{ Buried Waste } & Leaching & Groundwater & $\begin{array}{l}\text { Ingestion of } \\
\text { drinking water }\end{array}$ & Offsite resident & $\begin{array}{l}\text { This is an incomplete } \\
\text { pathway to exposure due to } \\
\text { high evapotranspiration and } \\
\text { low precipitation, low } \\
\text { potential for downward } \\
\text { transmission of water in the } \\
\text { vadose zone below the waste } \\
\text { cells, static zone below the } \\
\text { vadose zone, large distance to } \\
\text { groundwater, and low } \\
\text { groundwater velocity. }\end{array}$ \\
\hline & Erosion & \multirow{3}{*}{$\begin{array}{l}\text { - Atmosphere } \\
\text { - Cover soil }\end{array}$} & \multirow{3}{*}{$\begin{array}{l}\text { - External } \\
\text { radiation } \\
\text { - Ingestion of } \\
\text { soil } \\
\text { - Inhalation of } \\
\text { particulates } \\
\text { - Direct contact } \\
\text { with skin }\end{array}$} & \multirow{3}{*}{$\begin{array}{l}\text { - NNSS worker } \\
\text { - Visitor }\end{array}$} & \multirow{3}{*}{$\begin{array}{l}\text { The potential for exposure is } \\
\text { limited to NNSS workers and } \\
\text { visitors. These receptors may } \\
\text { be exposed to contaminants } \\
\text { through ingestion, inhalation, } \\
\text { or direct contact due to } \\
\text { inadvertent disturbance into } \\
\text { the waste or contact with } \\
\text { waste materials brought to } \\
\text { the surface by erosion or } \\
\text { biota. }\end{array}$} \\
\hline & $\begin{array}{l}\text { Biota (animal } \\
\text { burrowing/plant } \\
\text { uptake) }\end{array}$ & & & & \\
\hline & Excavation & & & & \\
\hline
\end{tabular}


Date: November 2010

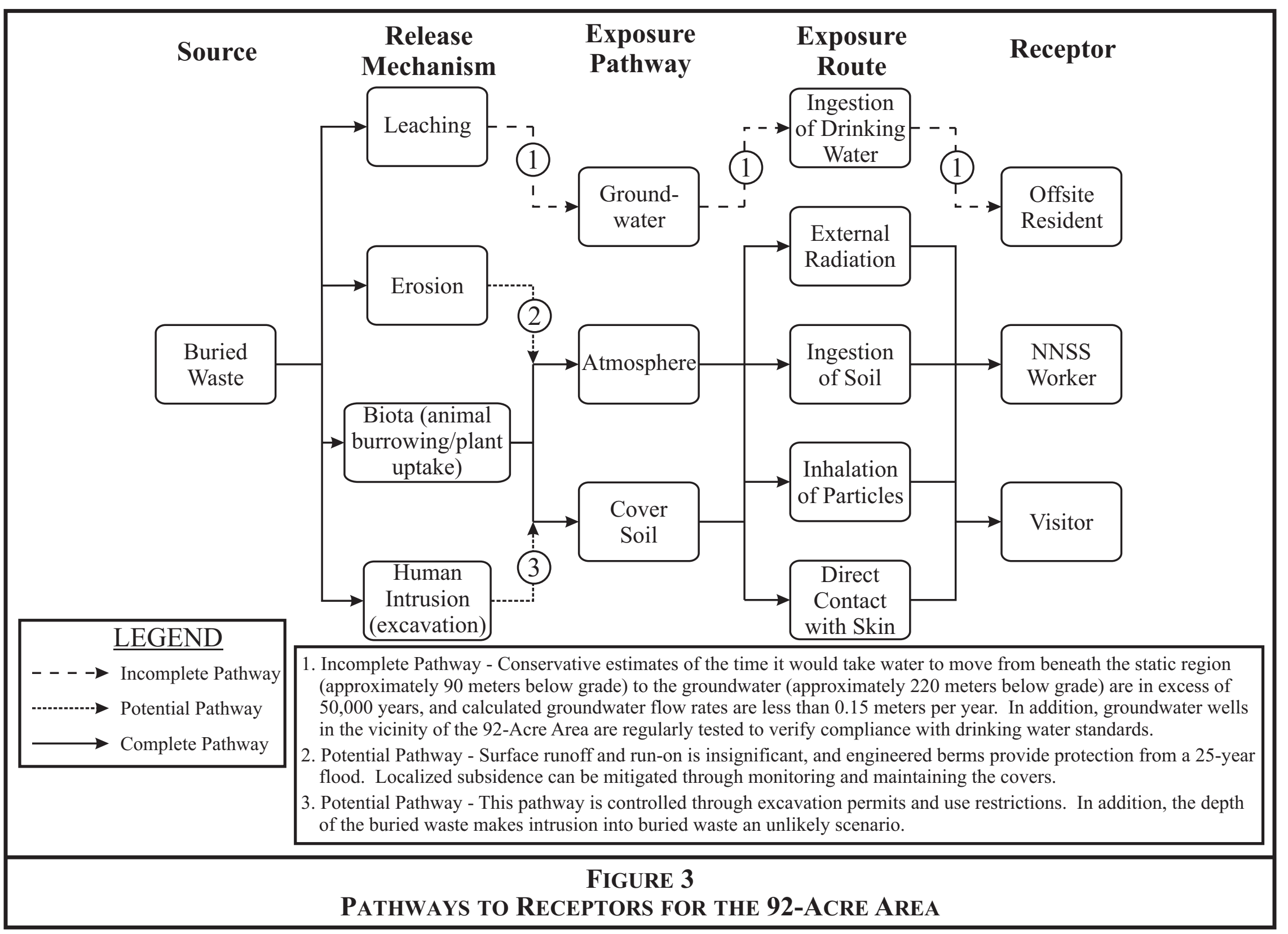




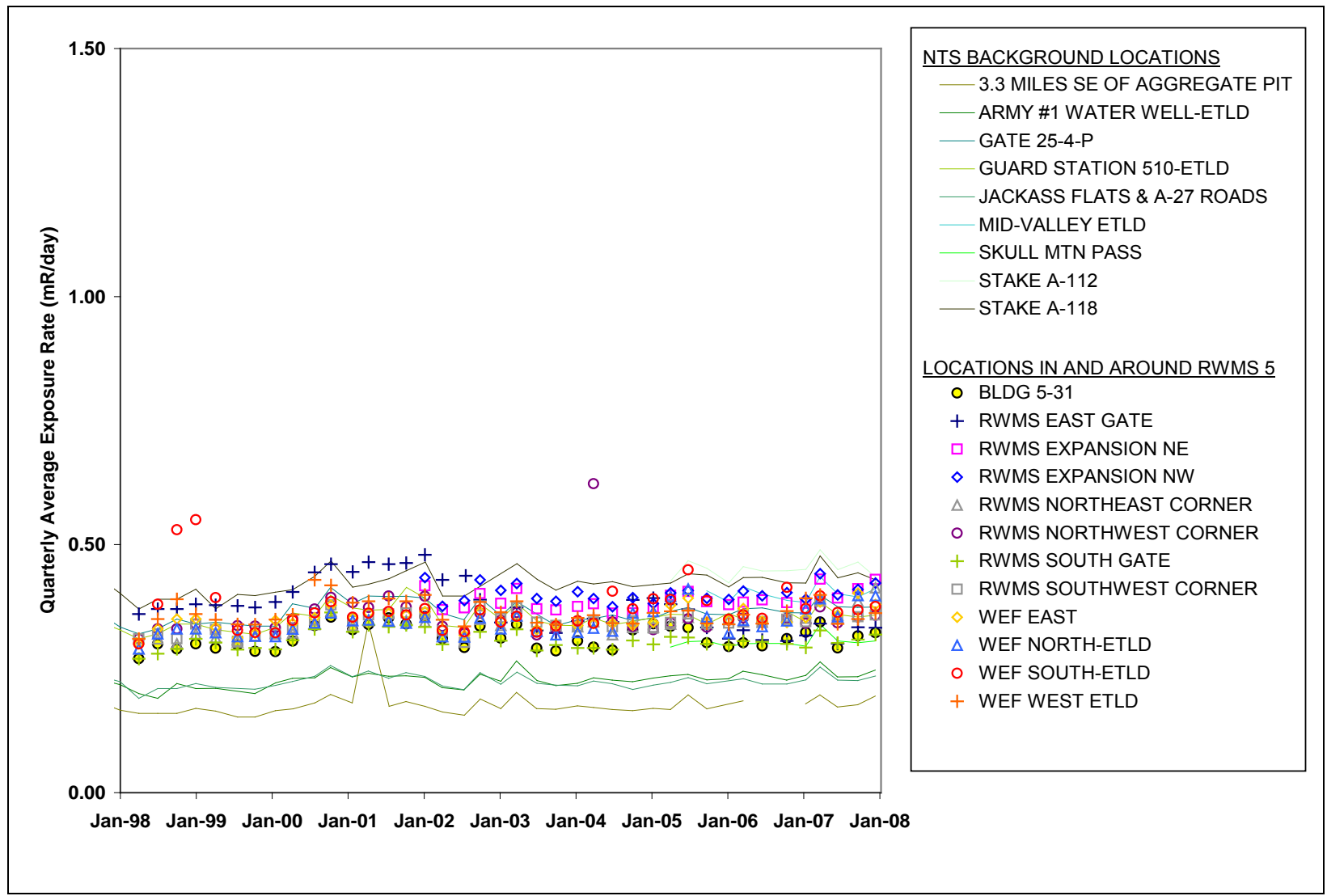

Figure 4. DiRect RAdiation Monitoring Results 


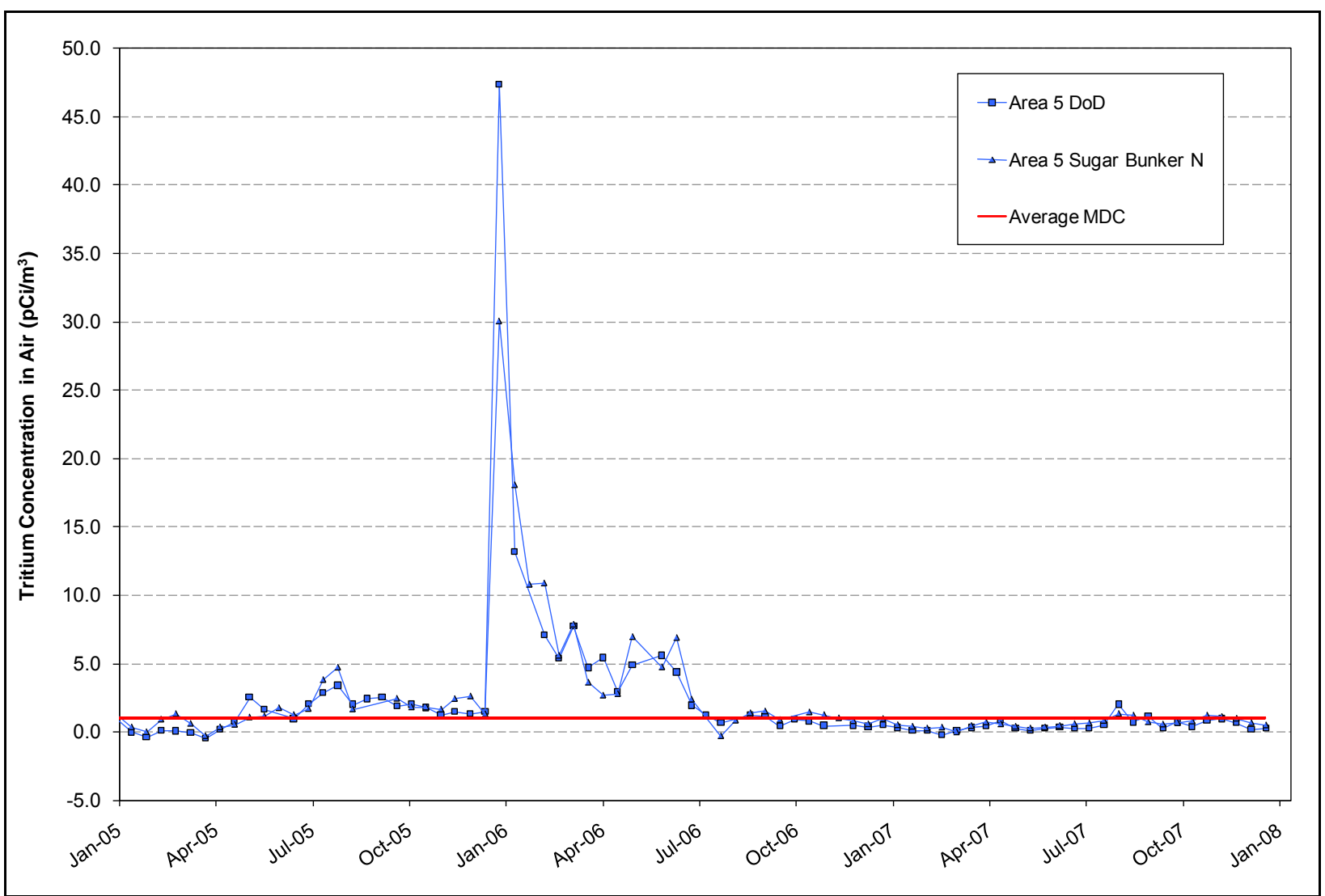

Figure 5. Tritium Air Monitoring Results 


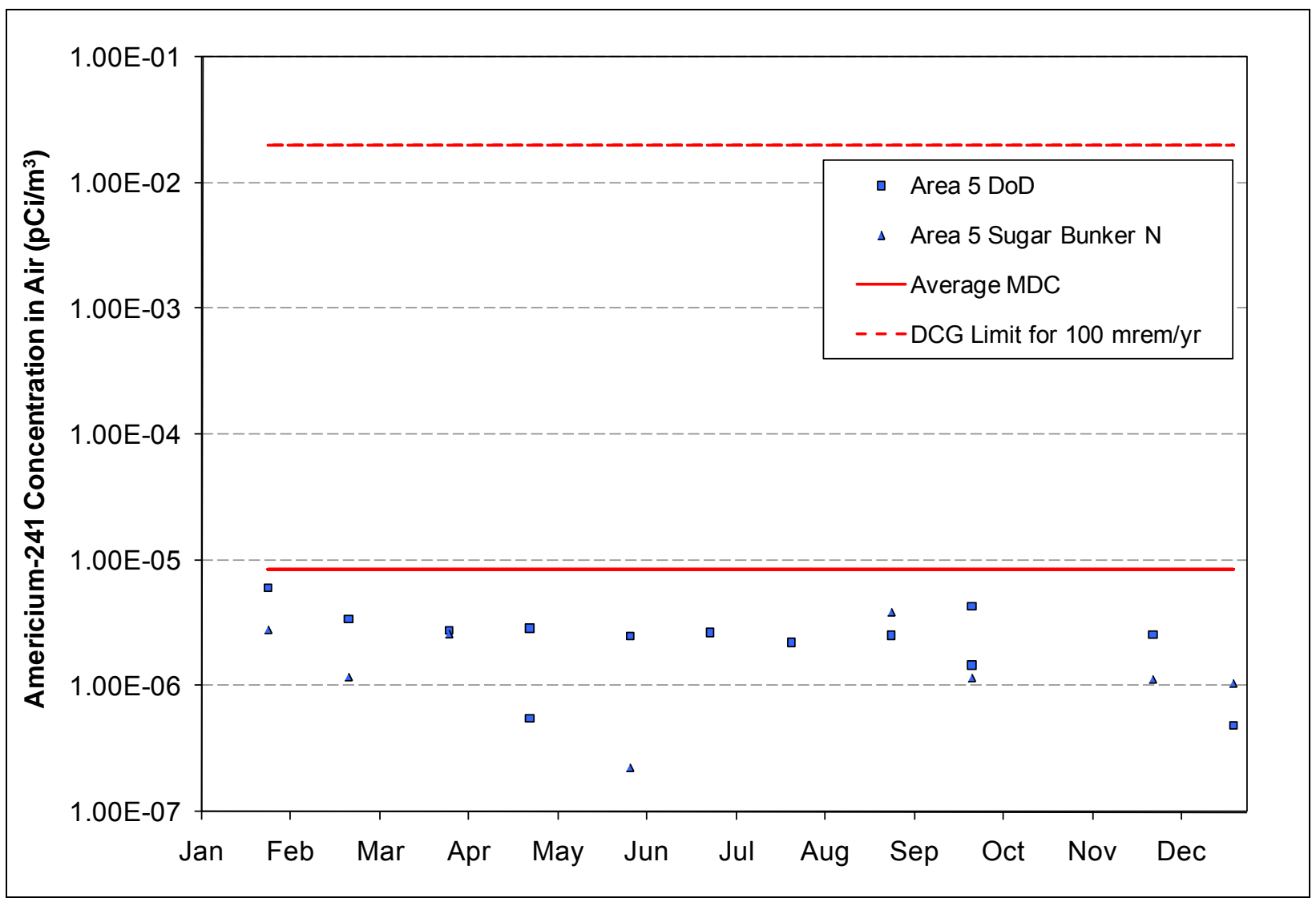

Figure 6. AMericium-241 Air Monitoring Results in 2007 


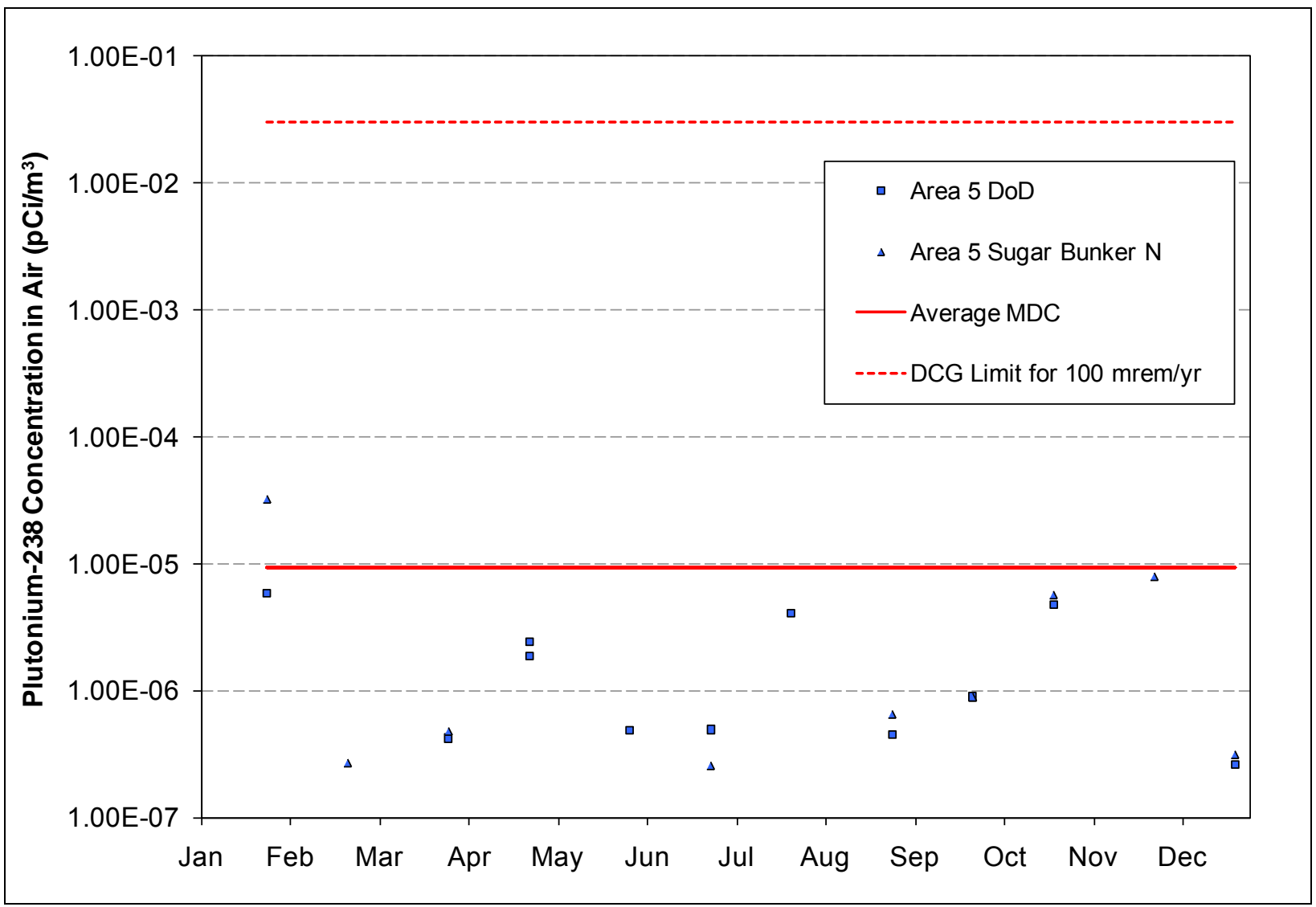

Figure 7. Plutonium-238 Air Monitoring Results in 2007 


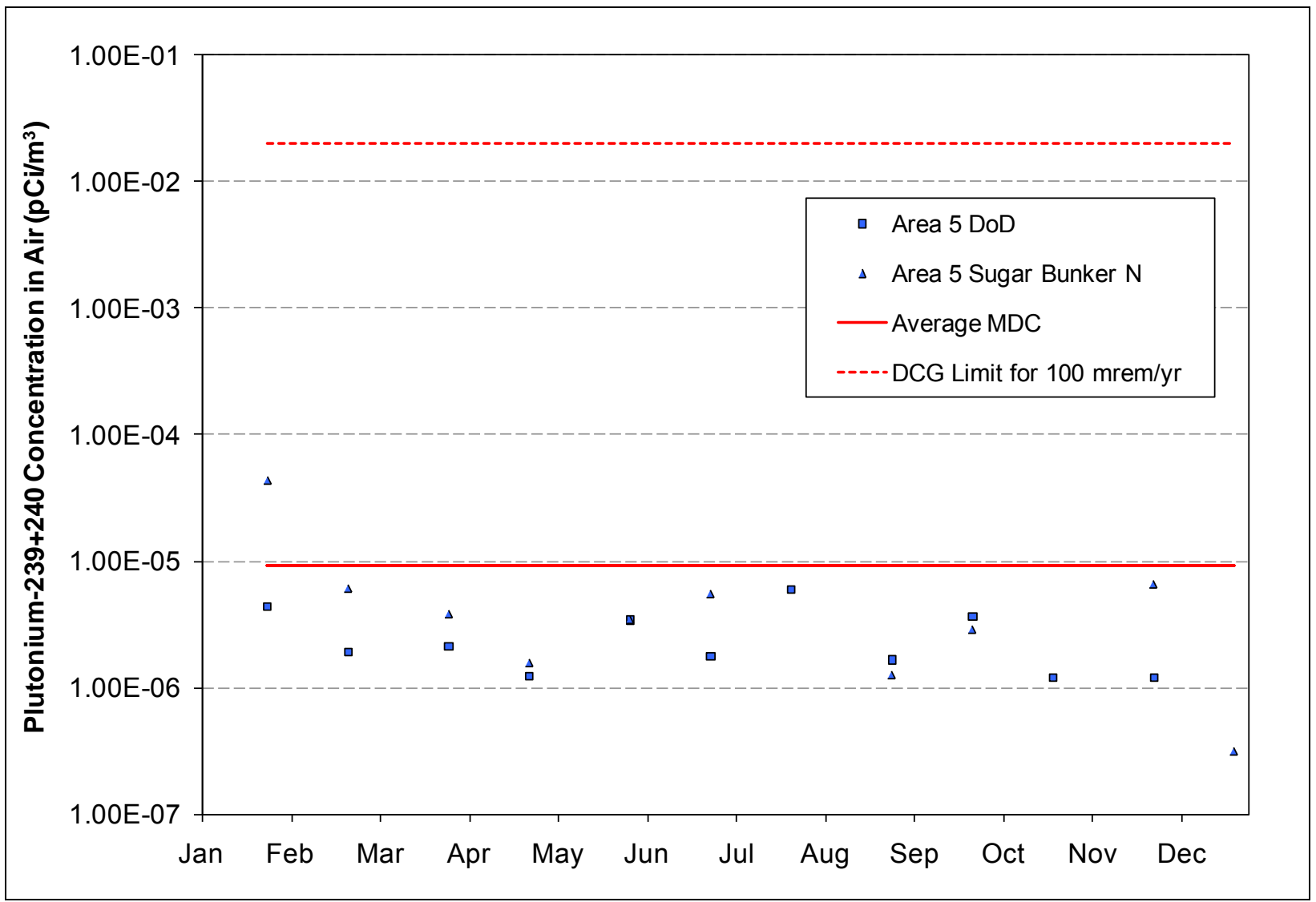

Figure 8. Plutonium-239/240 Air Monitoring Results in 2007 


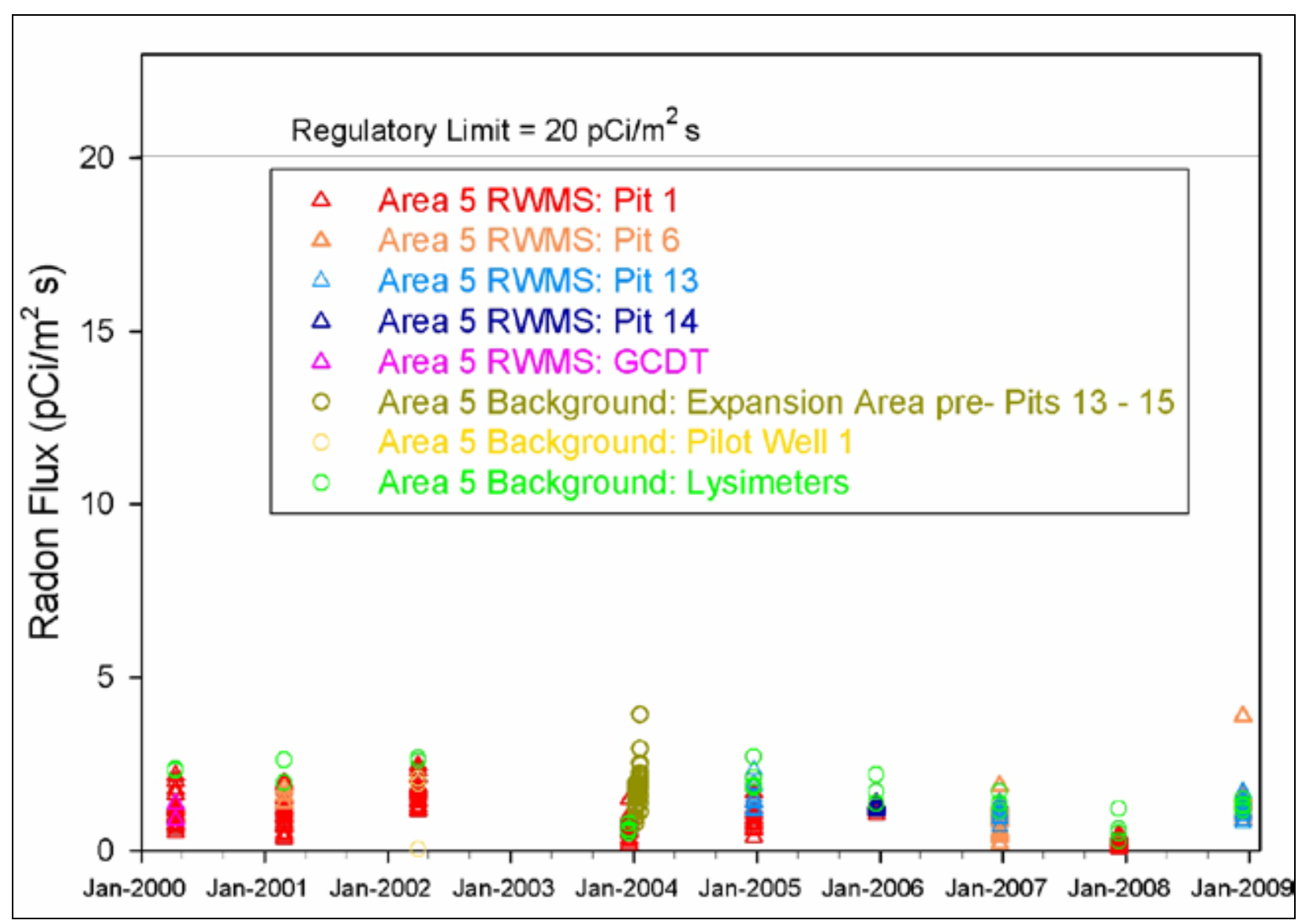

Figure 9. RAdon Flux Monitoring Results 


\subsubsection{Groundwater Monitoring}

Groundwater elevation data from manual measurements taken since the wells were drilled in 1993, as shown in Figure 10, indicate that the water table is flat, with low groundwater velocities. The locations of the three wells are shown on Figure 2.

Indicators of contamination ( $\mathrm{pH}$, specific conductance, total organic carbon, total organic halides, and tritium) show no groundwater contamination. Measured $\mathrm{pH}$ has remained stable and within the ILs of 7.6 and 9.2 (Figure 11). Specific conductance values have remained stable and below the IL of 0.44 millimhos per centimeter $(\mathrm{mmhos} / \mathrm{cm})$ (Figure 12). Total organic carbon values have remained low and stable, and are generally at or below the IL of 1 milligram per liter $(\mathrm{mg} / \mathrm{L})$ (Figure 13). Total organic halide values have remained stable and below the IL of 50 micrograms per liter $(\mu \mathrm{g} / \mathrm{L})$ (Figure 14). Tritium values have remained stable and below the IL of 2,000 picocuries per liter ( $\mathrm{pCi} / \mathrm{L}$ ) and the $\mathrm{MDC}$ since monitoring began (Figure 15). Negative values for tritium shown in Figure 15 are the result of background subtraction.

General water chemistry parameters (calcium, magnesium, potassium, sodium, iron, manganese, bicarbonate, sulfate, silicate, chloride, and fluoride) indicate similar groundwater composition in the three wells and stable groundwater chemistry throughout the monitoring period (NSTec, 2009).

\subsubsection{Meteorology Monitoring}

The daily maximum and minimum air temperatures at the Area 5 RWMS for 2007 are shown in Figure 16. The average air temperature in 2007 was $16.4^{\circ} \mathrm{C}$. The maximum and minimum air temperatures in 2007 were $43.9^{\circ} \mathrm{C}$ and $-14.7^{\circ} \mathrm{C}$. The daily average relative humidity in 2007 was approximately 28 percent and ranged from 2 to 100 percent (Figure 17). The daily average barometric pressure in 2007 was 90.5 kilopascals (kPa) (Figure 18) (NSTec, 2008).

In 2007, the average wind speed was 2.7 meters per second $(\mathrm{m} / \mathrm{s})$, and the maximum gust was $20.9 \mathrm{~m} / \mathrm{s}$ (Figure 19). Wind rose diagrams illustrate wind direction and wind speed distribution in each direction using hourly wind data. Generally, winds are more frequent from the north, with higher wind speeds from the south. The wind rose diagram for the Area 5 RWMS is presented in Figure 20 (NSTec, 2008).

Rainfall at the Area 5 RWMS in 2007 was below average, totaling 123.8 millimeters (mm). The average annual precipitation for 1995 to 2007 is $130.7 \mathrm{~mm}$. Figure 21 depicts the daily total precipitation for 2007. Historical precipitation data recorded at the Well 5B station (approximately 5.5 kilometers south of the Area 5 RWMS) and the Area 5 RWMS are provided in Figure 22 (NSTec, 2008).

Reference evapotranspiration, calculated using solar radiation, air temperature, relative humidity, wind speed, and barometric pressure, was $1,594 \mathrm{~mm}$ in 2007 . This is 12.9 times the amount of precipitation in 2007 , indicating that precipitation will be removed from the soil by evapotranspiration before it is allowed to infiltrate into the covers toward the waste cells. 


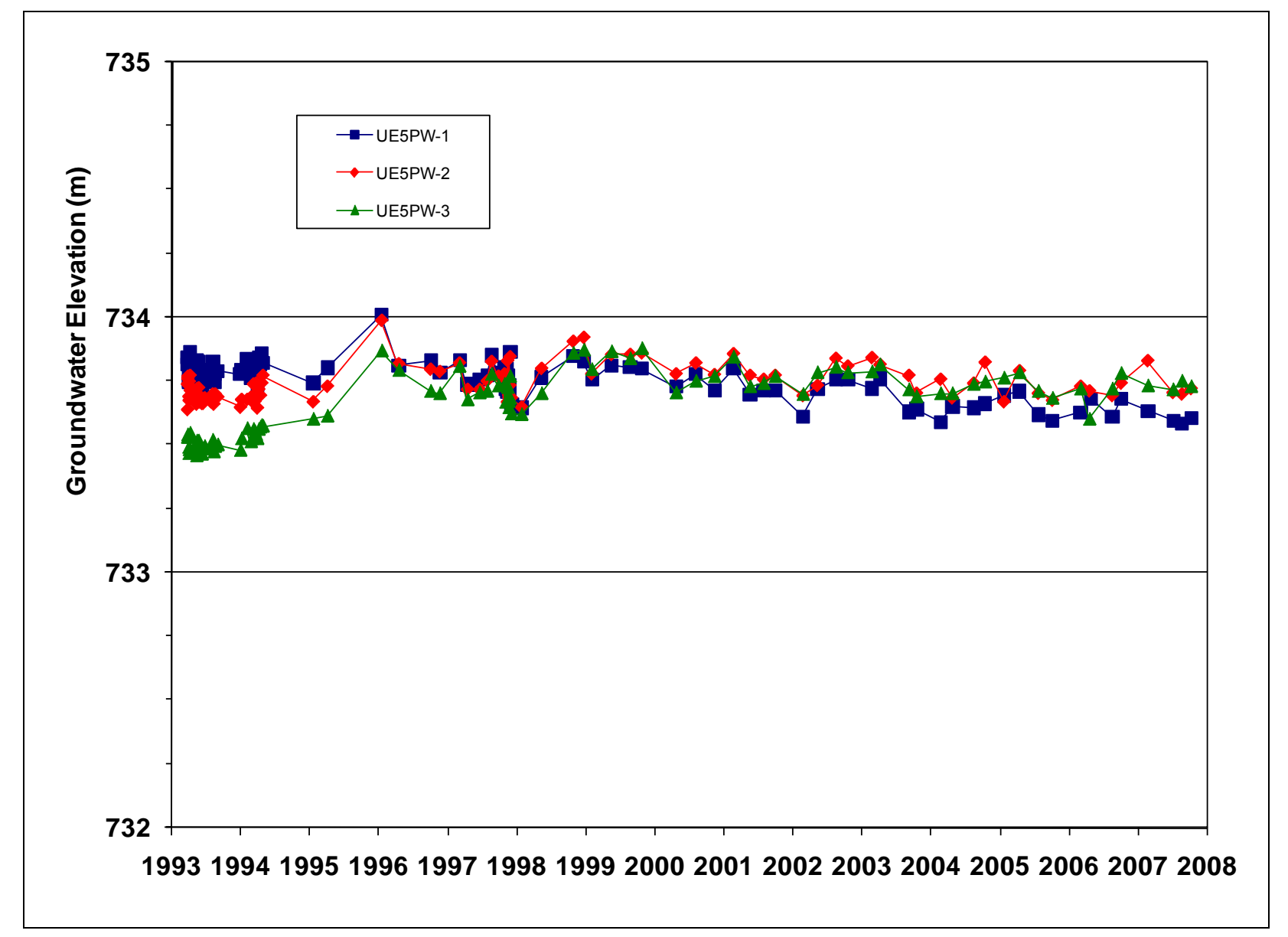

FIGURE 10. GROUNDWATER ELEVATION RESULTS 


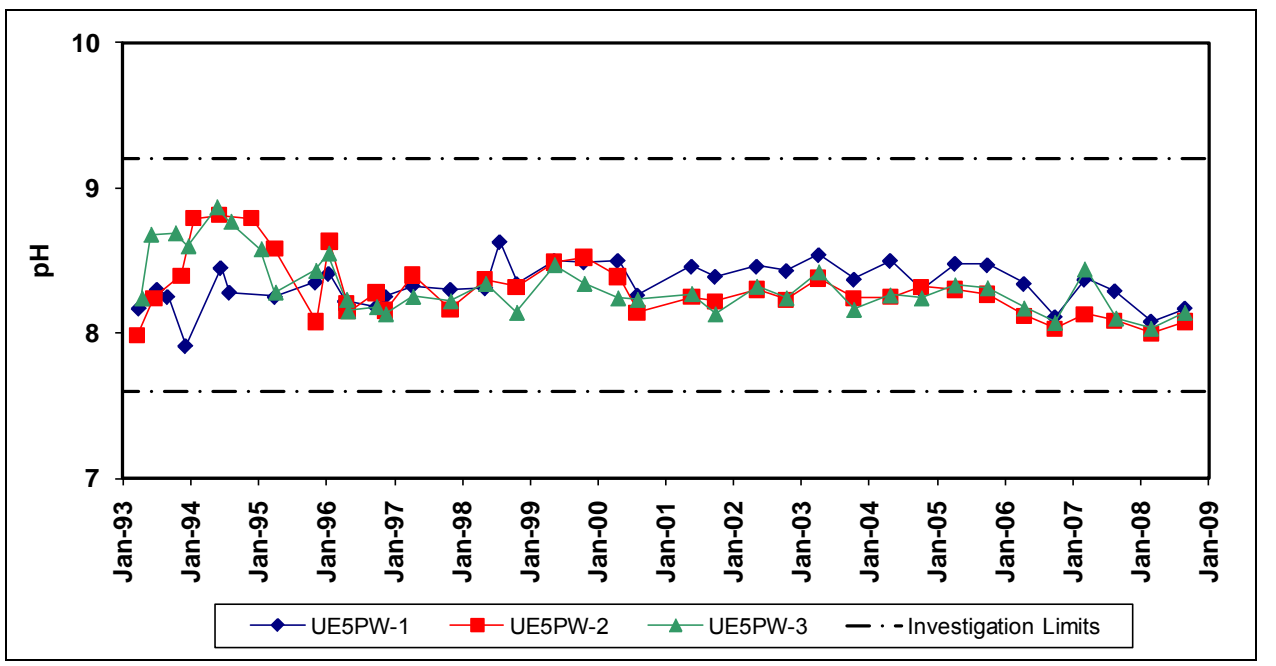

Figure 11. MEASURED PH GroundWATER MONITORING RESUltS

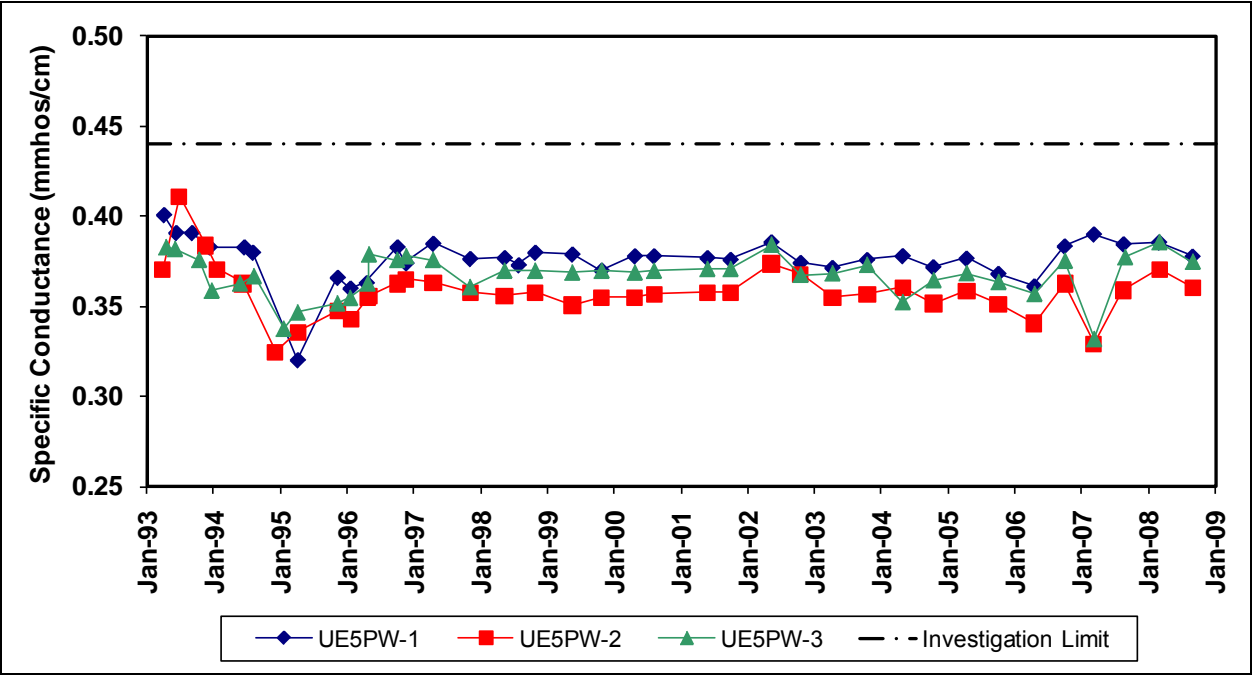

Figure 12. SPECIFIC CONDUCTANCE GROUNDWATER MONITORING RESULTS 


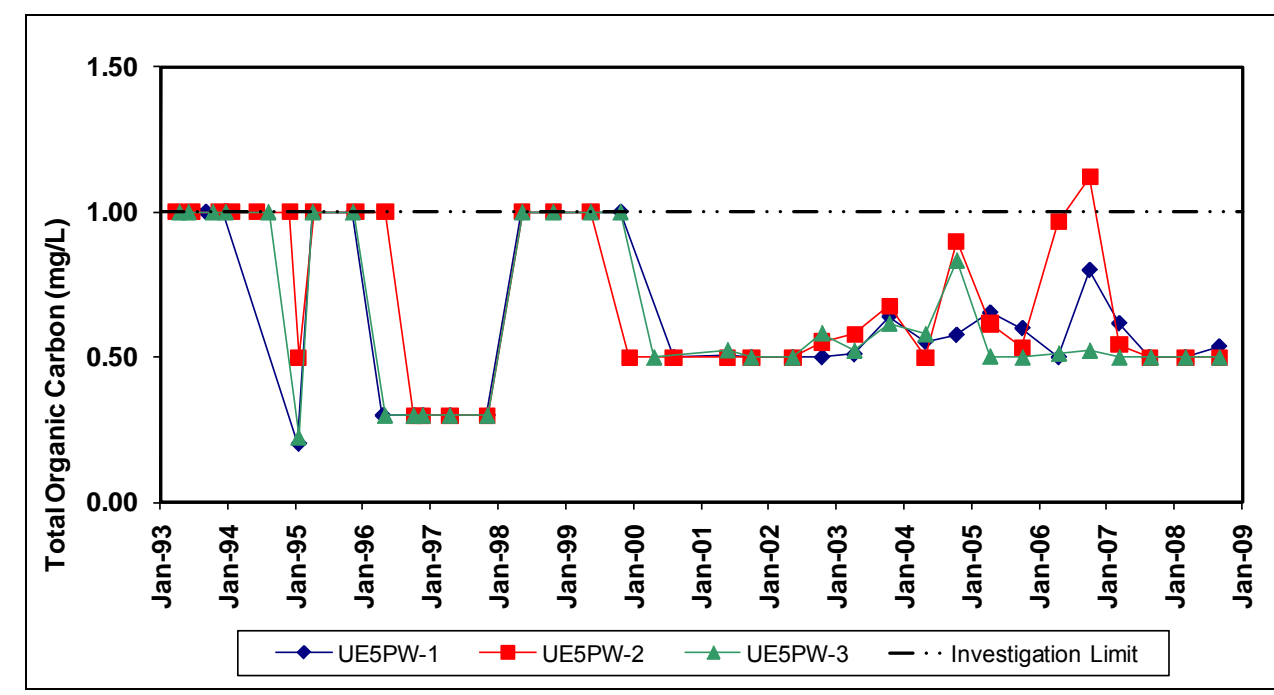

Figure 13. Total Organic Carbon GroundWater Monitoring Results

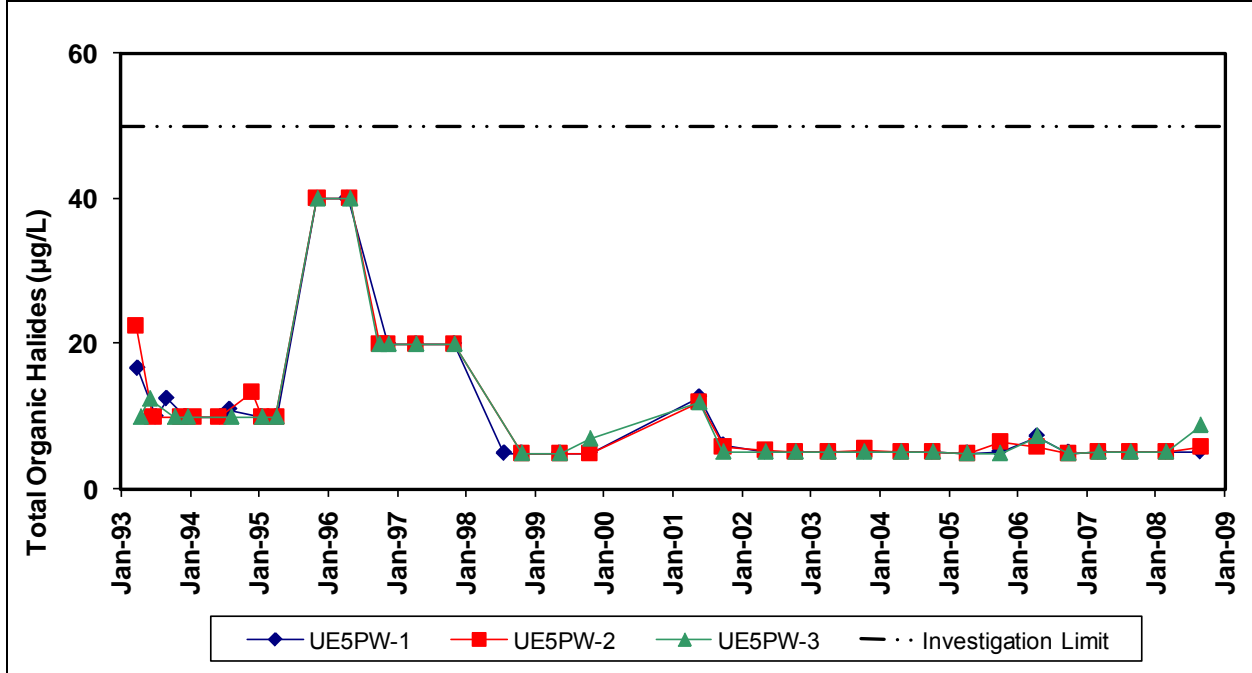

Figure 14. Total Organic Halides GroundWater Monitoring RESUlts 


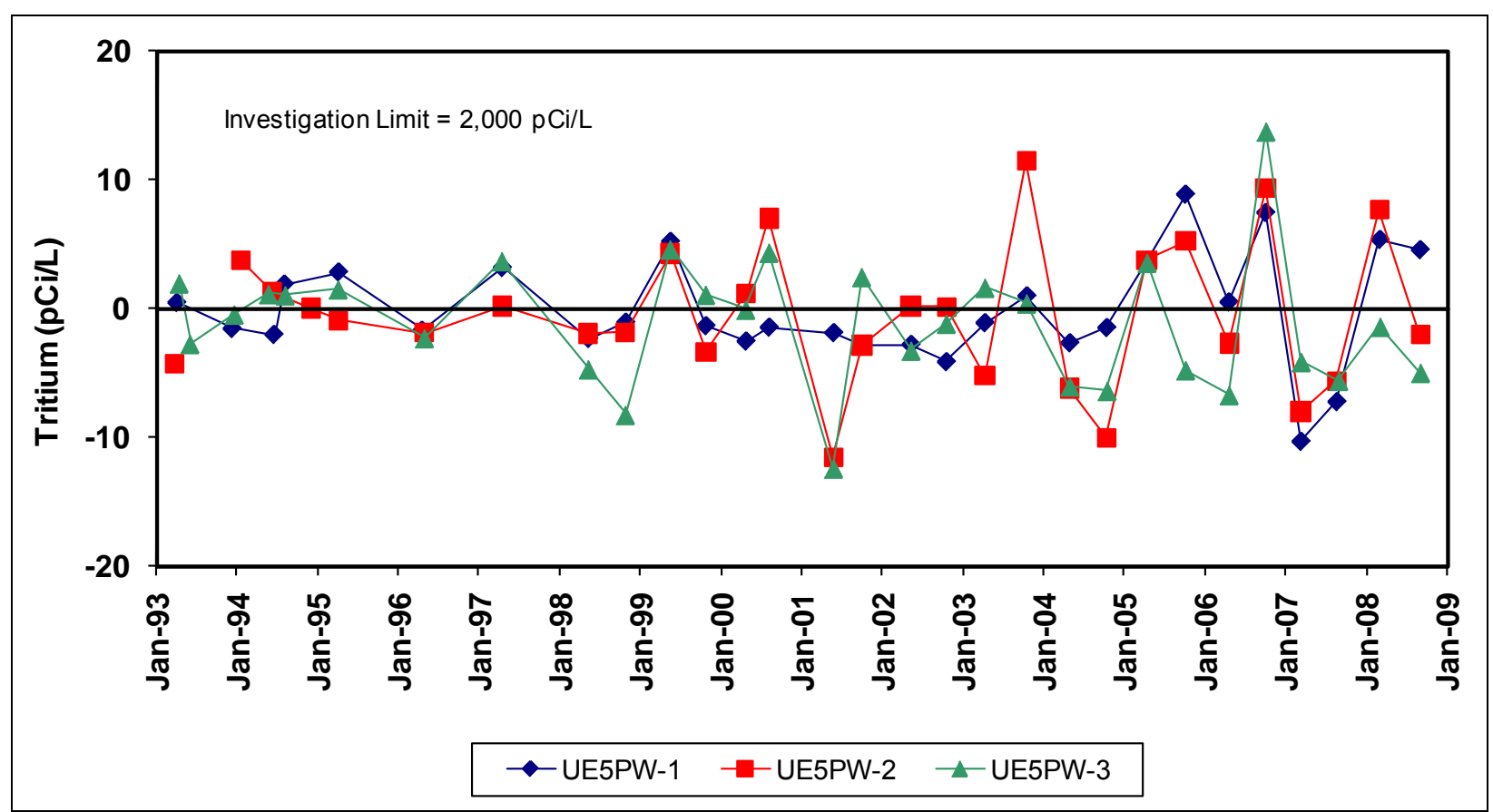

Figure 15. Tritium GroundWATER Monitoring RESUltS 


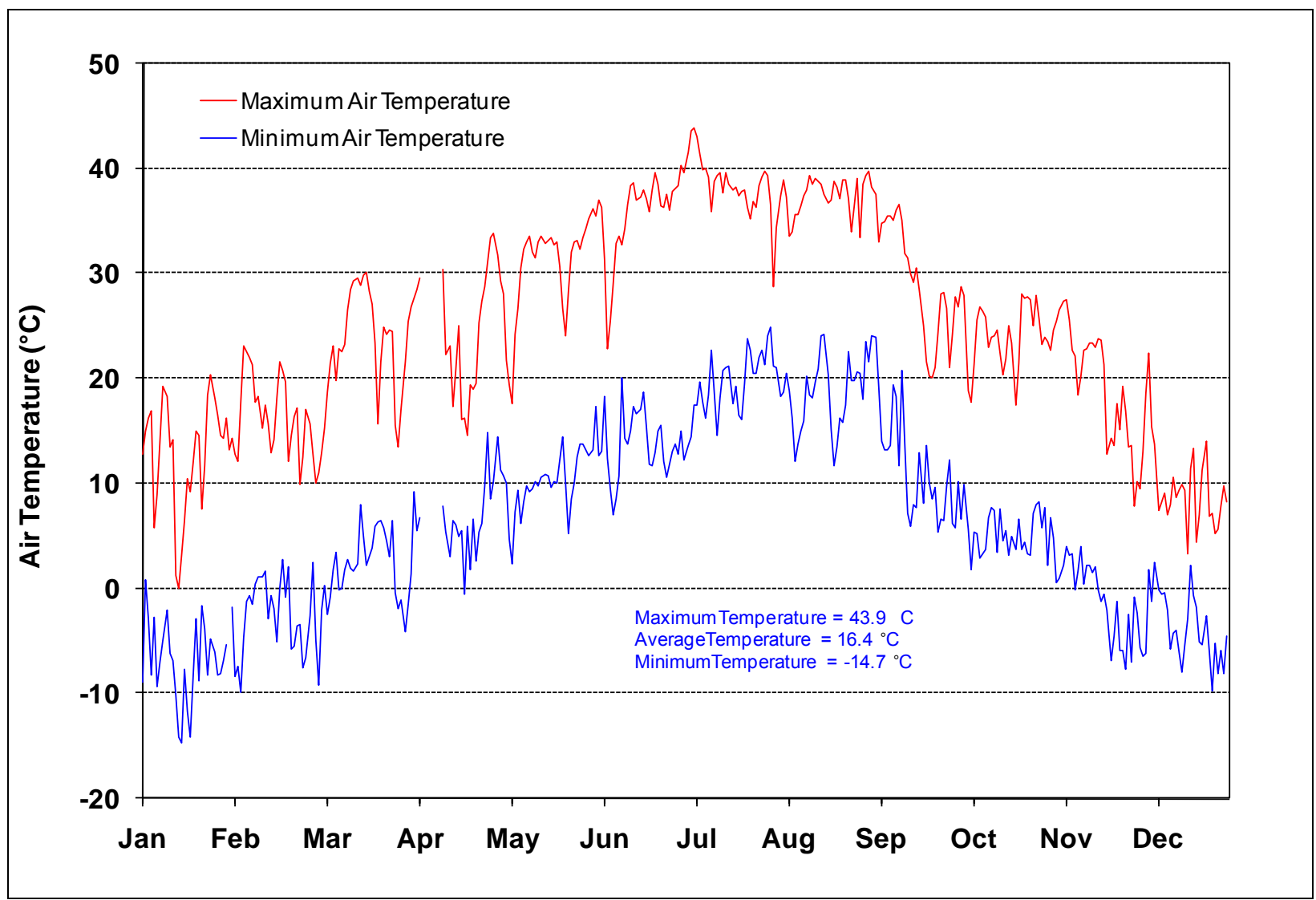

Figure 16. Daily MAXimum AND Minimum Air TeMPERATURE IN 2007 


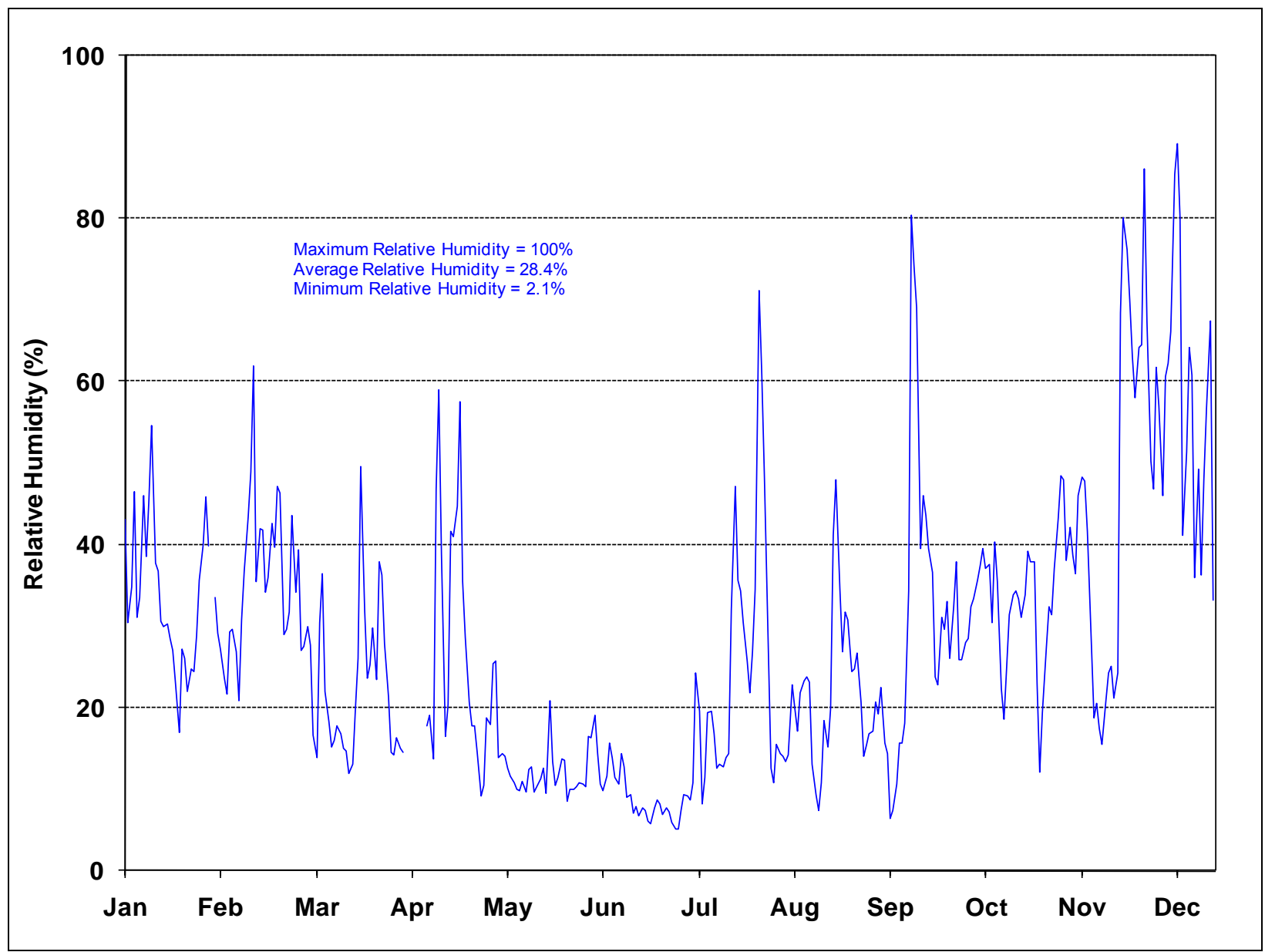

Figure 17. DAily Average Relative Humidity in 2007 


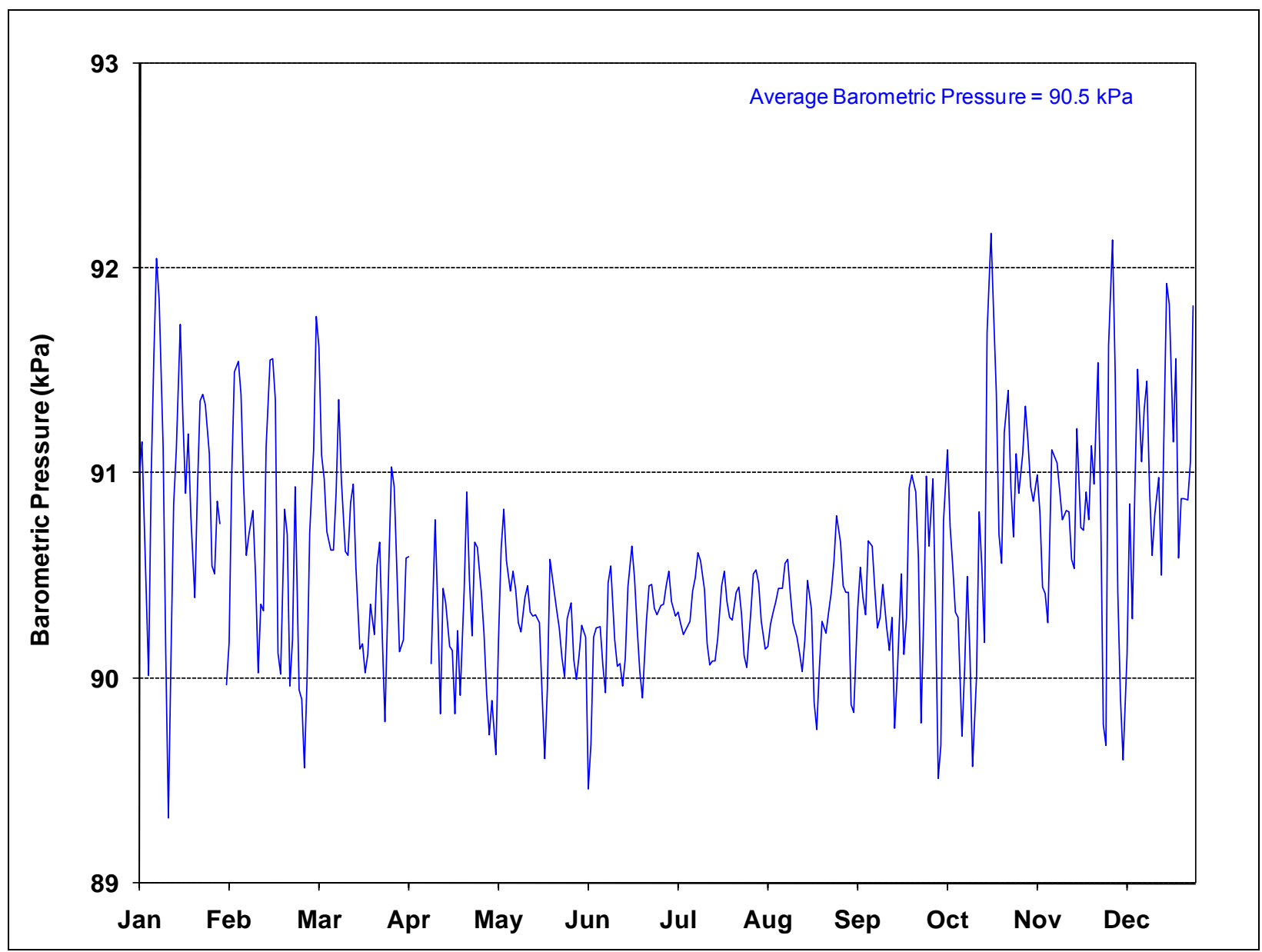

Figure 18. Daily Average Barometric Pressure in 2007 


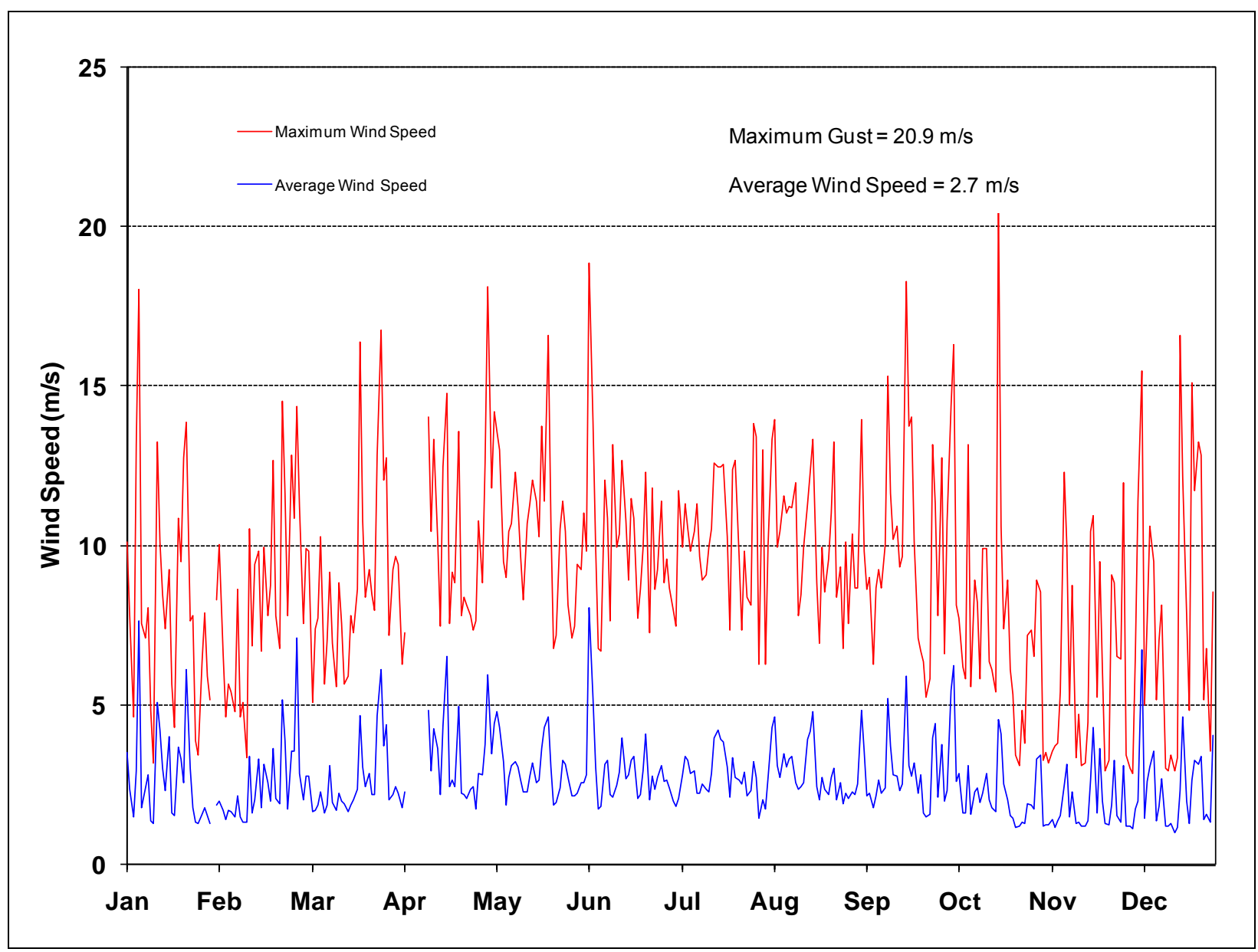

Figure 19. Daily MaXimum and AVERAgE Wind SPEED IN 2007 


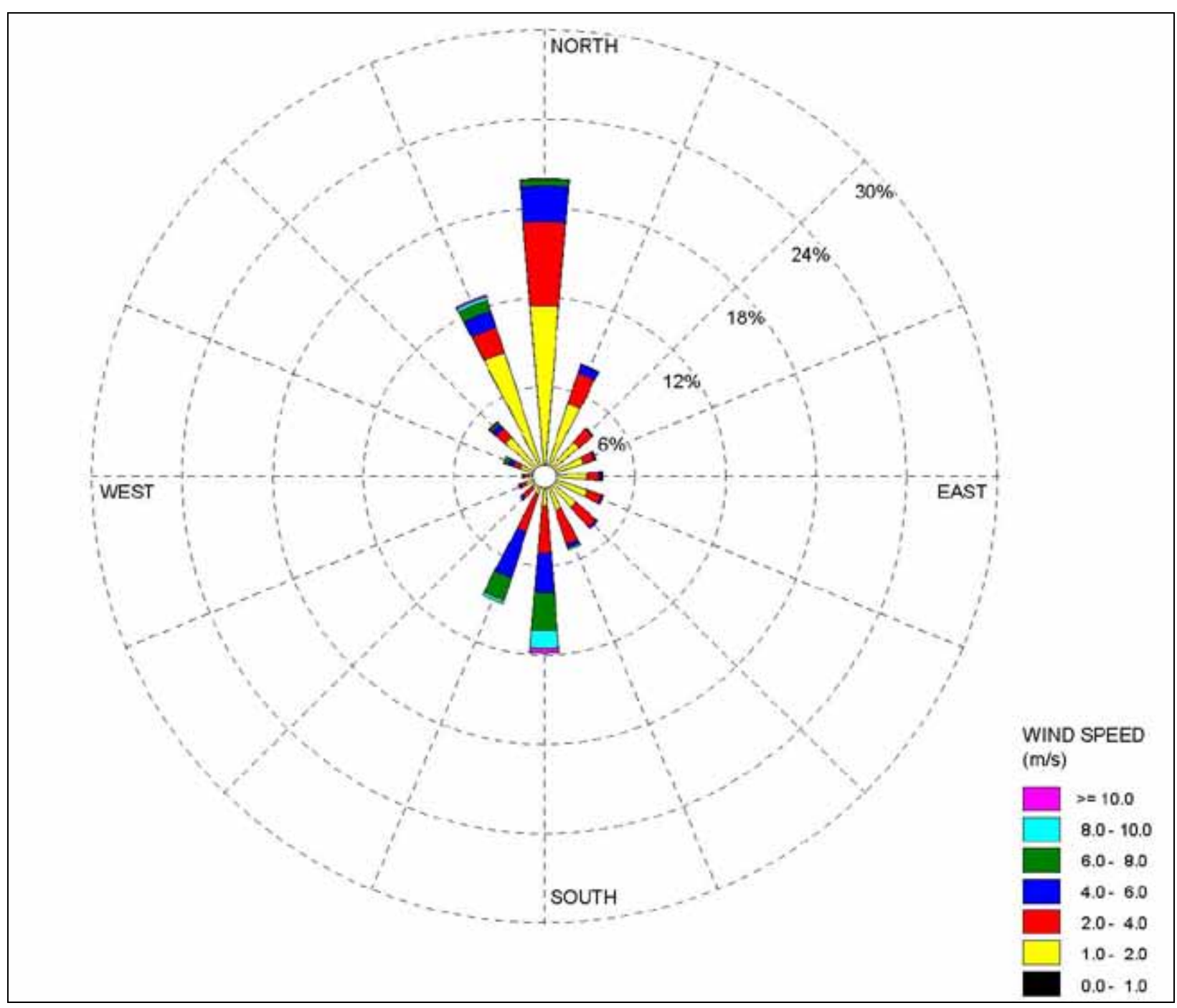

FIGURE 20. WIND RoSE DIAGRAM 


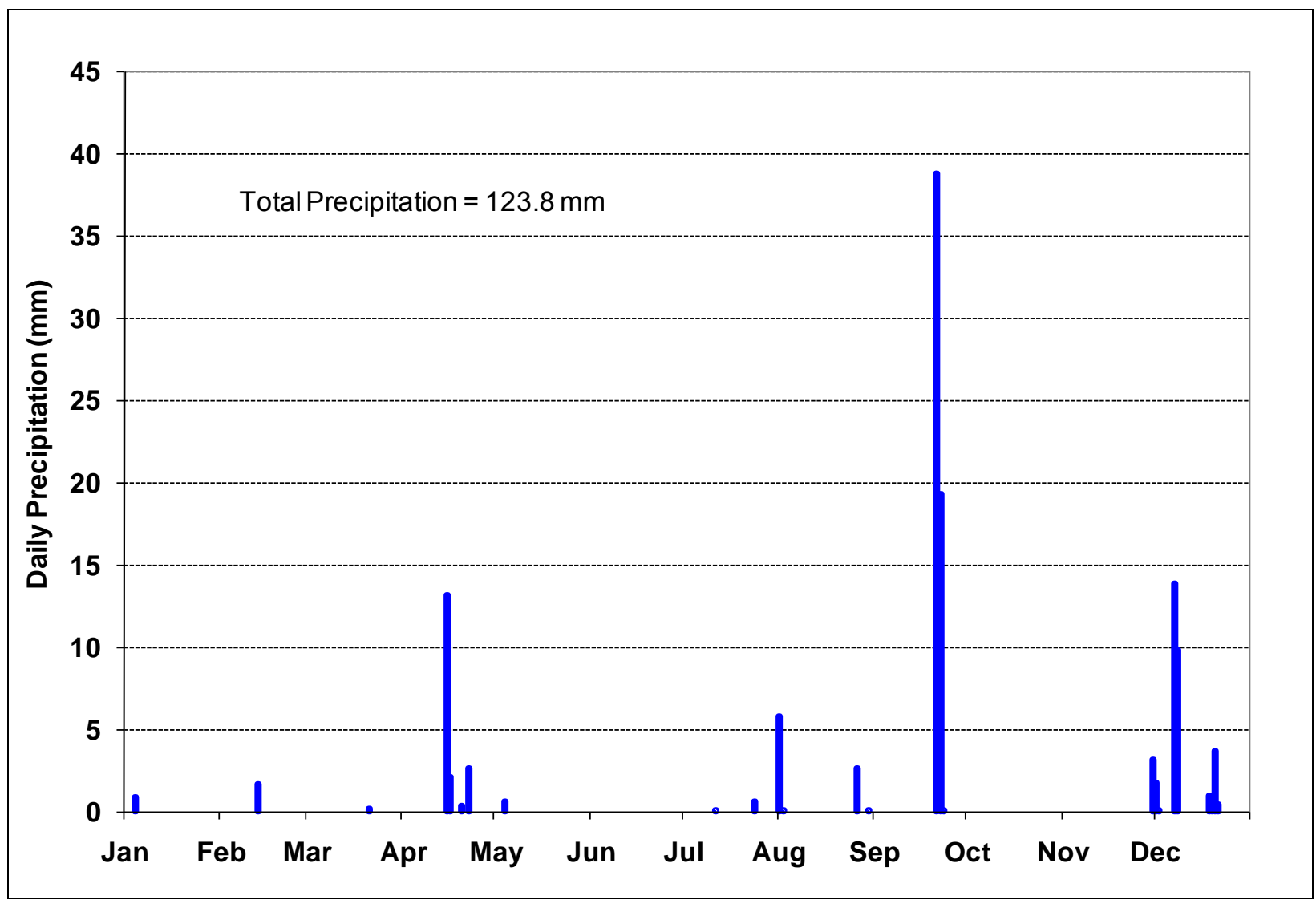

Figure 21. Daily Precipitation In 2007 


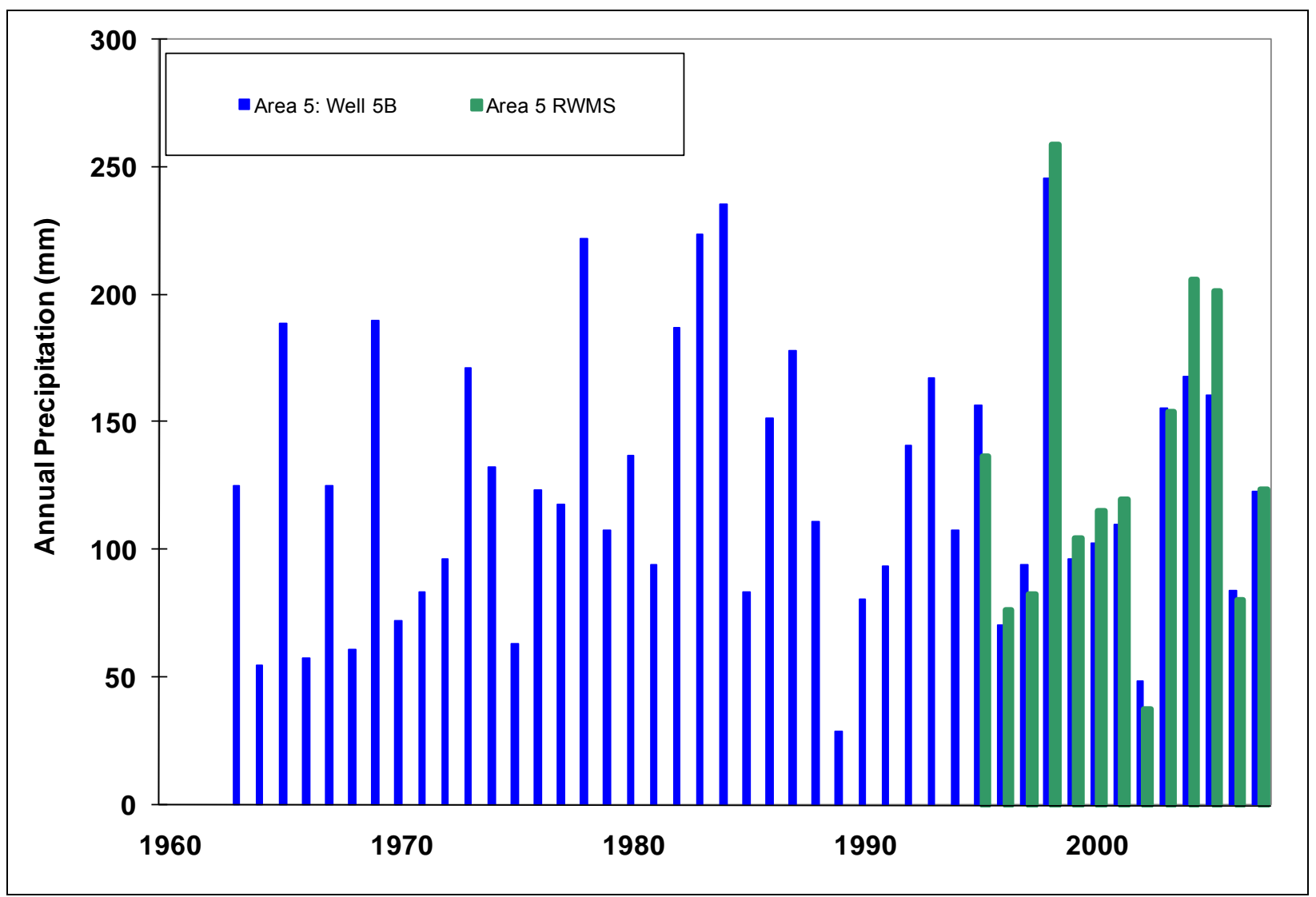

Figure 22. Annual Precipitation 


\subsubsection{Vadose Zone Monitoring}

Total soil water storage at the weighing lysimeters for 1994 to 2007 is illustrated in Figure 23. The vegetated lysimeter is considerably drier than the bare-soil lysimeter. The average soil water storage depth in the vegetated lysimeter from 1996 to 2007 was $114 \mathrm{~mm}$. This is equivalent to an average volumetric moisture content of 5.72 percent. For the same period, the average soil water storage depth in the bare lysimeter was $207 \mathrm{~mm}$, which is equivalent to an average volumetric moisture content of 10.35 percent. In 2007, the average soil water storage depth in the vegetated lysimeter was $110 \mathrm{~mm}$, and the average water storage depth in the bare lysimeter was $206 \mathrm{~mm}$ (NSTec, 2008).

In 1998, TDR probes were buried $1.2 \mathrm{~m}$ beneath the floor of Pit 5 (P05). Approximately $4.4 \mathrm{~m}$ of waste and approximately $2.3 \mathrm{~m}$ of operational cover were placed above these probes during disposal operations. Measured volumetric moisture content in the floor of Pit 5 has remained constant at approximately 10 percent since monitoring began (Figure 24). The stable moisture content indicates that no moisture has percolated to $1.2 \mathrm{~m}$ below the waste (NSTec, 2008).

In 1999, TDR probes were installed in the operational cover of Pit 3 (P03) at two locations (north and south) at depths ranging from 10 to 180 centimeters $(\mathrm{cm})$ below the top of the cover. Precipitation events beginning in October 2004 infiltrated into the cover and percolated below the deepest probe at both the north (Figure 25) and south (Figure 26) locations in early March 2005. This depth is below the range where surface evaporation can have an effect on soil moisture. During 2006 and 2007, the gradual drying of the soil profile at Pit 3 continued. By September 2007, the volumetric moisture content at $180 \mathrm{~cm}$ at both locations had returned to approximately 12 percent (NSTec, 2008).

In 2000, TDR probes were installed in the operational cover of Pit 5 (P05) at depths ranging from 15 to $180 \mathrm{~cm}$ below the top of the cover. Precipitation events beginning in October 2004 infiltrated into the cover and percolated below the deepest probe in April 2005 (Figure 27). Similar to Pit 3 (P03), the gradual drying of the soil profile continued in 2007 (NSTec, 2008).

\subsubsection{Soil Gas Monitoring}

Sample results for soil gas tritium since 1990 indicate that upward migration of tritium from the waste is extremely slow. Tritium concentrations with depth and time are illustrated in Figure 28. Concentrations have remained constant and low from the surface to $12.2 \mathrm{~m}$. At $15.2 \mathrm{~m}$, concentrations slowly increased through 1997 but then leveled off. Concentrations at 19.8, 25.9, 33.5, and $36.3 \mathrm{~m}$, which are adjacent to the tritium source, have increased since 1990. The highest measured tritium concentration of 363.9 microcuries per cubic meter $\left(\mu \mathrm{Ci} / \mathrm{m}^{3}\right)$, collected at a location adjacent to buried waste, indicates that the 2.2 million curies of tritium originally buried at the site remains contained. Risk from tritium exposure is low due to lack of an exposure pathway, tritium's relatively short half-life of 12.3 years, and the low migration rate (NSTec, 2008). 


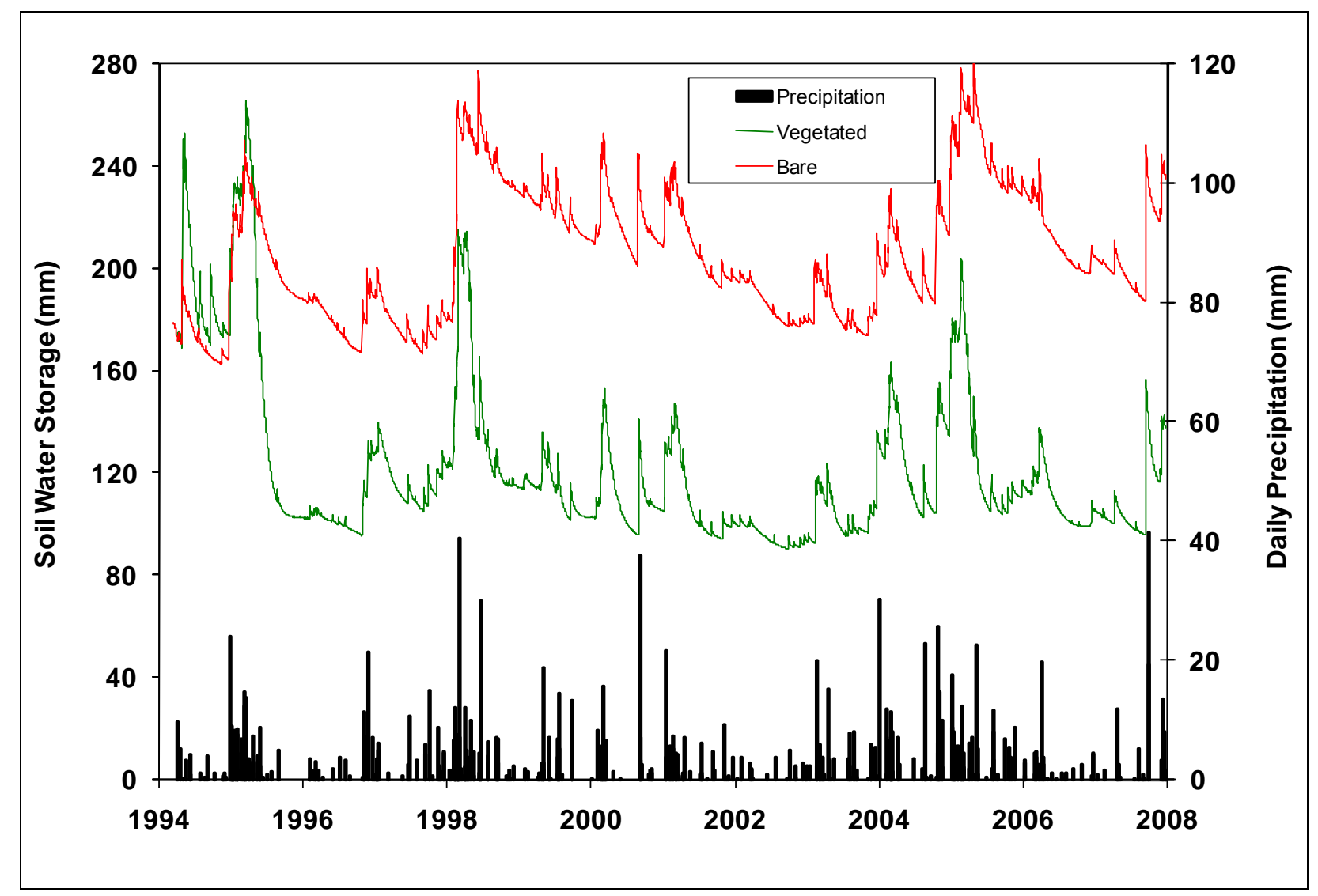

Figure 23. VAdOSE Zone MONITORING RESUlts AT THE WEIGHING LySIMETERS 


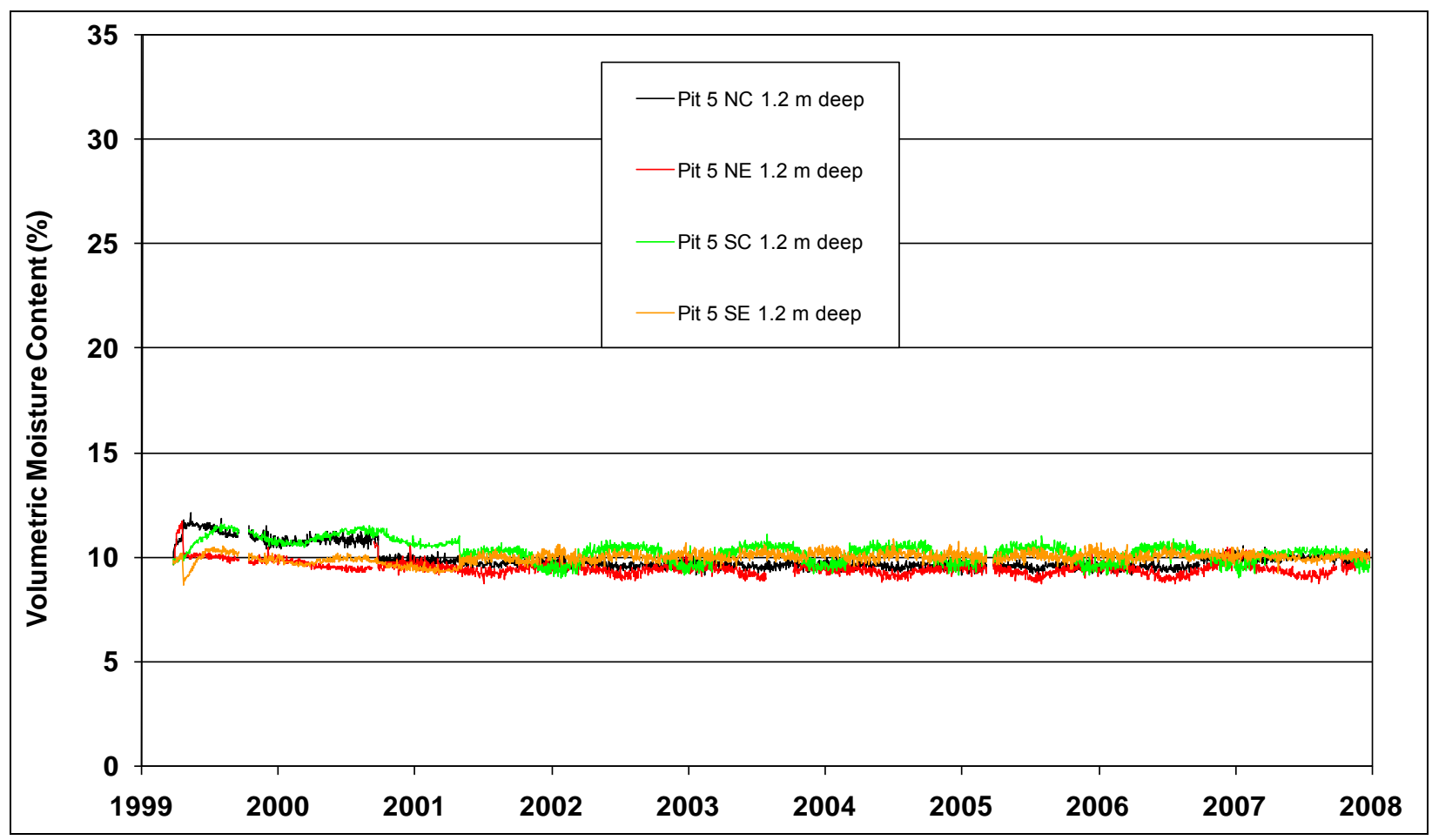

Figure 24. Vadose Zone Monitoring Results in the Floor of Pit 5 


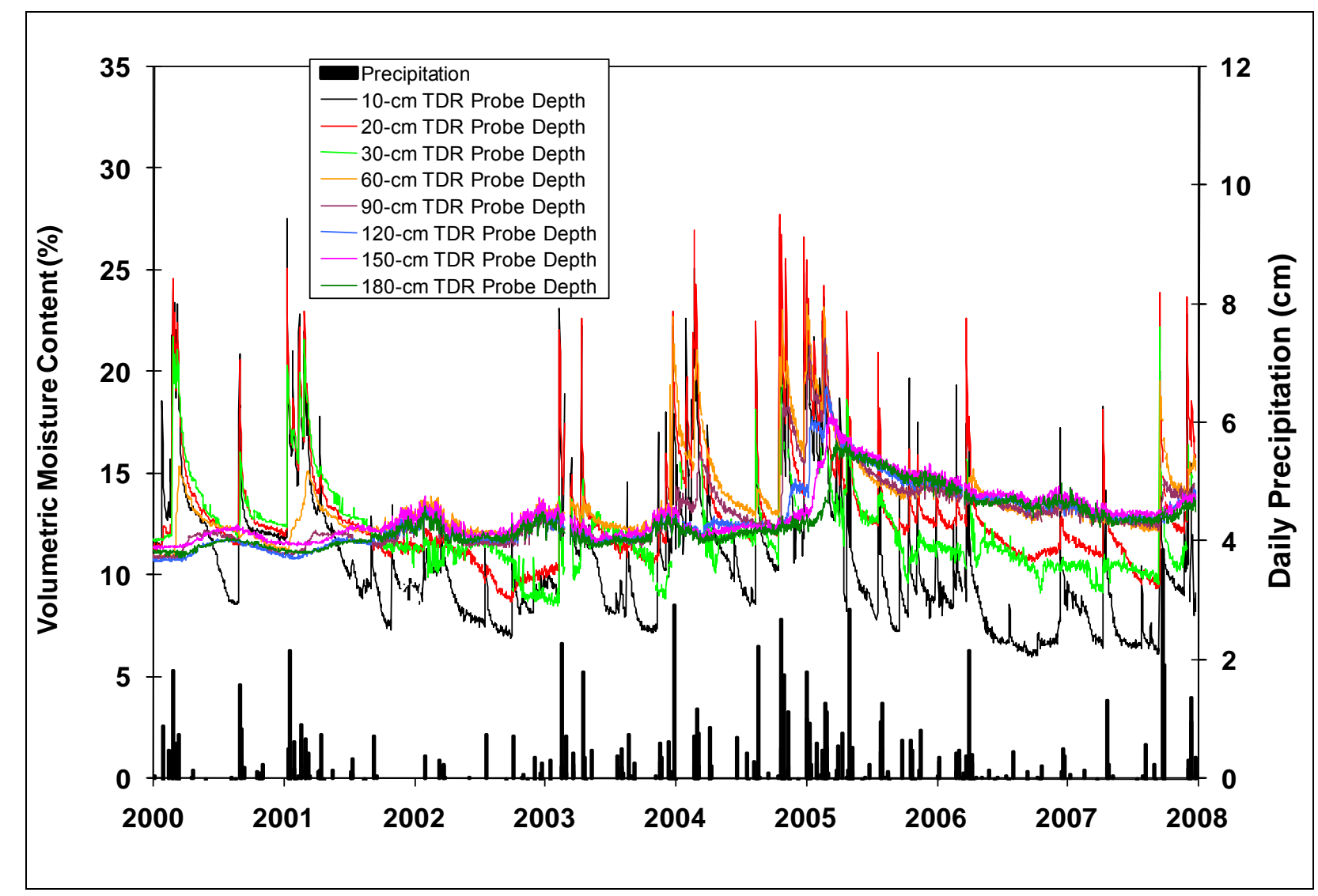

Figure 25. Vadose Zone Monitoring Results in the Operational Cover of Pit 3 North 


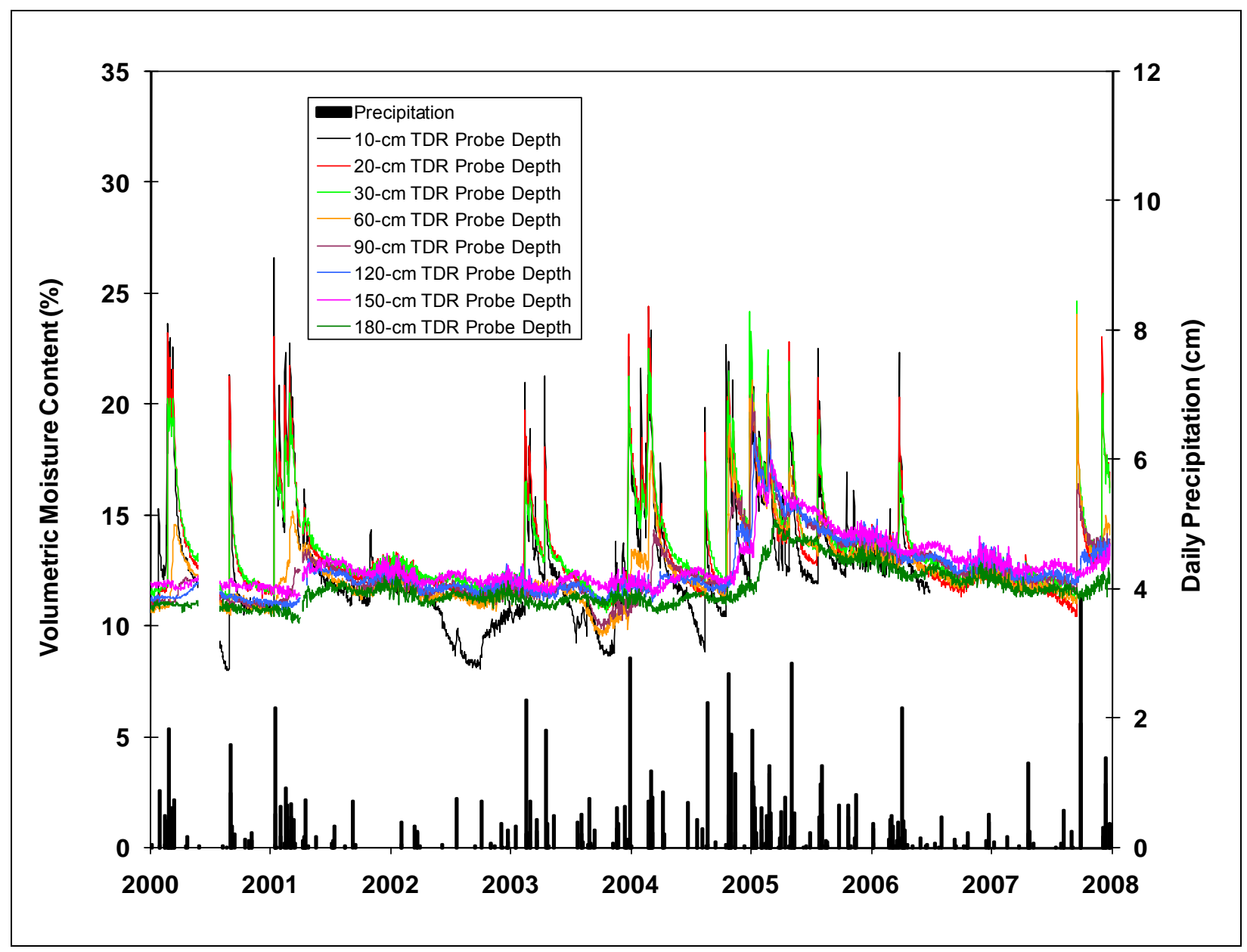

Figure 26. Vadose Zone Monitoring Results in the Operational Cover of Pit 3 South 


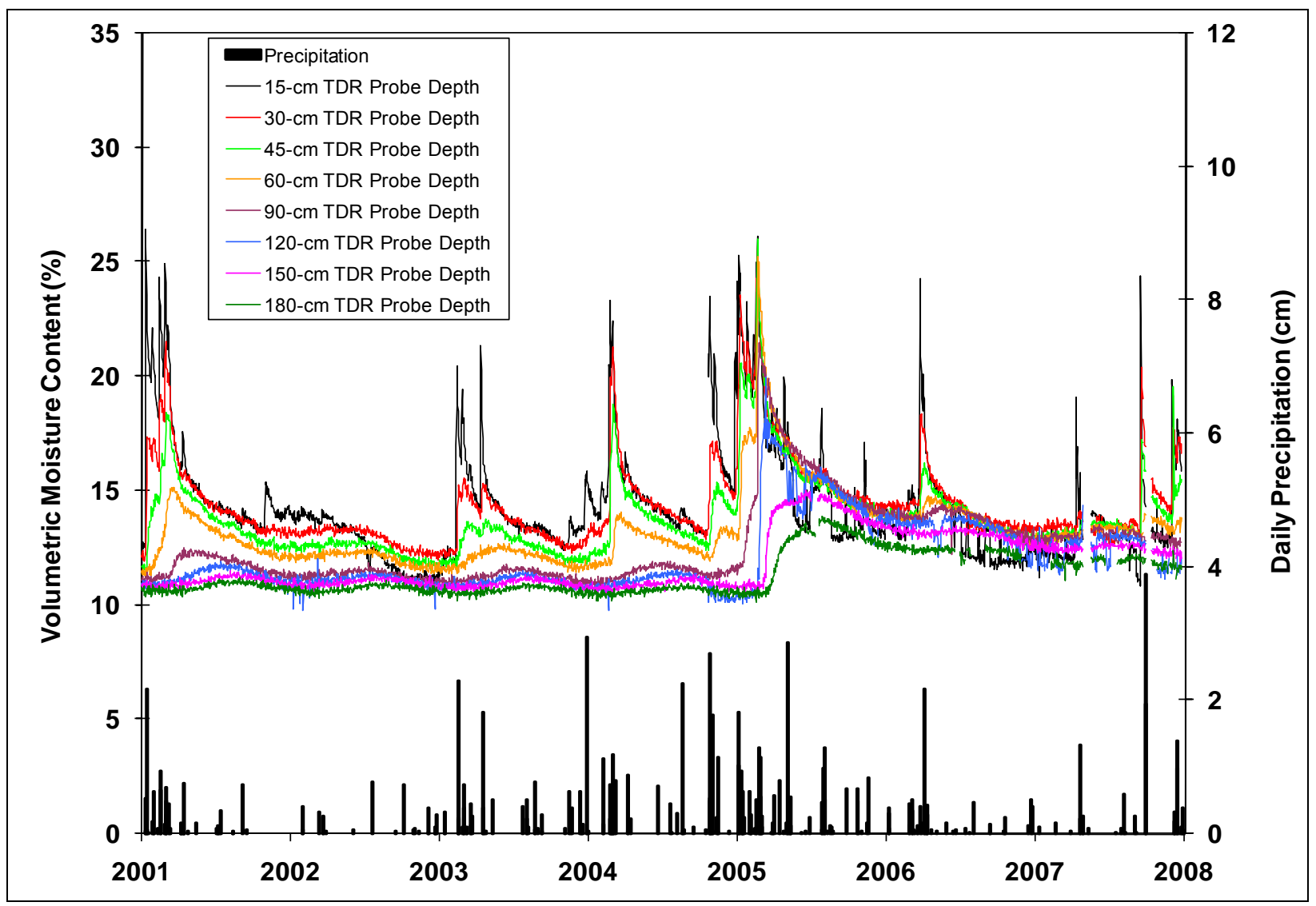

Figure 27. Vadose Zone Monitoring Results in the Operational Cover of Pit 5 
92-Acre Area and CAU 111 CADD/CAP Section: CAI Summary

Revision: 1

Date: November 2010

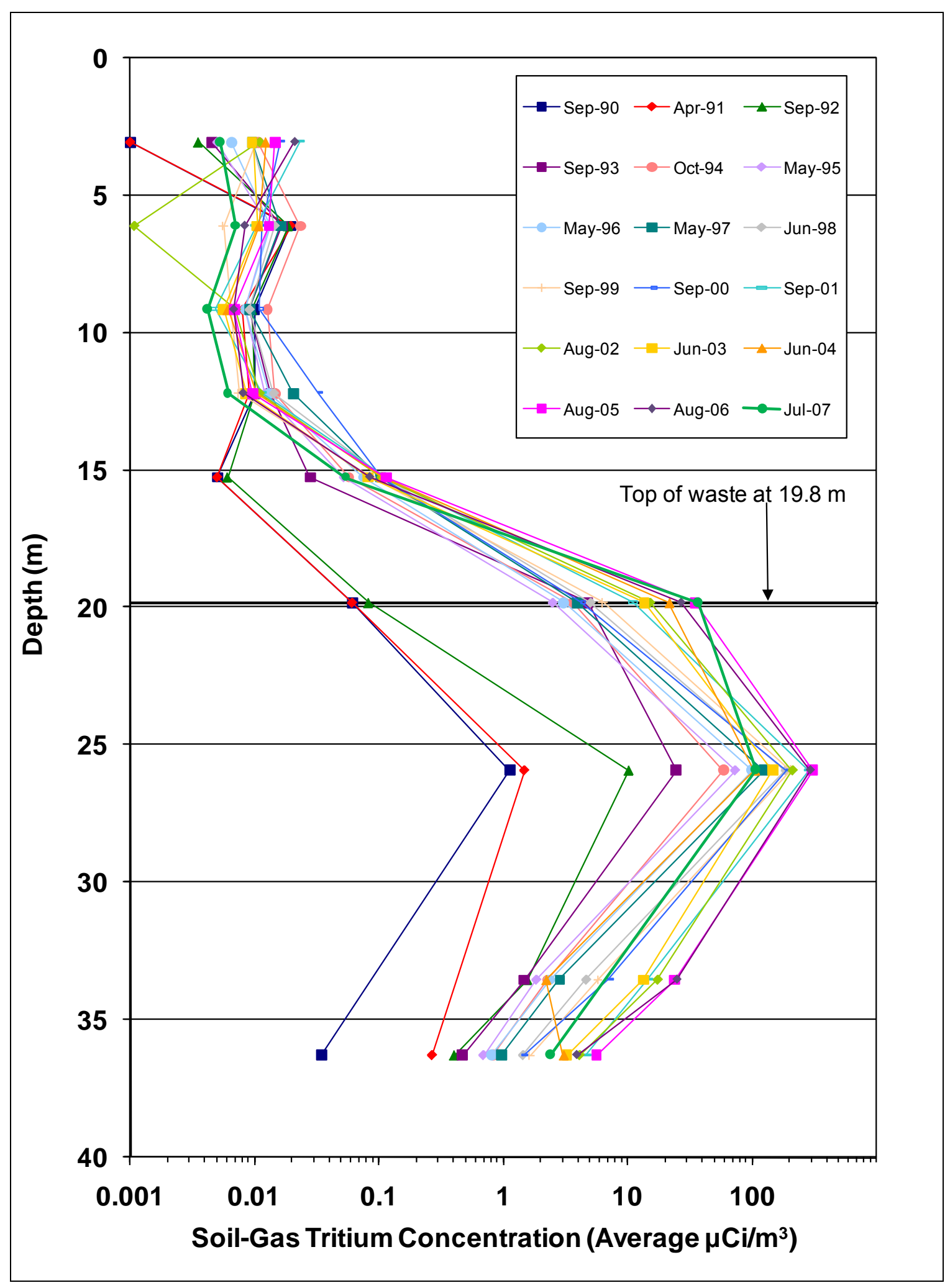

Figure 28. SoIl Gas Monitoring ReSUltS 


\subsubsection{Biota Monitoring}

The locations of small mammal burrows and ant nests at the Area 5 RWMS in 2007 are mapped in Figure 29. Burrows are concentrated on the side slopes of the operational covers. Most burrow entrances appear to be inactive. Burrow densities are much higher in older covers (e.g., P01, P02, T02B, and T04B) compared to newer covers (e.g., P04 and P05). Low radionuclide concentrations in soil excavated by small mammals and ants indicate that these animals have not intruded into the waste (NSTec, 2008).

In 2007, biota samples were collected from five plants, one small mammal, and three small mammal burrows or ant nests. Figure 30 shows the sample locations and tritium results in $\mathrm{pCi} / \mathrm{L}$. Historical tritium concentrations are illustrated in Figure 31 and Figure 32. Tritium uptake by biota is due to its high mobility as tritiated water. Tritiated water moves upward through waste covers by gaseous diffusion, gaseous and liquid advection, plant uptake and transpiration, and soil evaporation. Due to the very low water content in soil samples collected in 2007, tritium could not be measured. Radionuclide concentrations for strontium, cesium, plutonium, and americium were not statistically different from background (NSTec, 2008).

\subsubsection{Performance Assessment Model}

A dynamic model of the movement of moisture established through the performance assessment model of the vadose zone is illustrated in Figure 33. The model hypothesized four regions in the vadose zone. Zone I, approximately $35 \mathrm{~m}$ thick at the top of the vadose zone, is a dynamic region of upward liquid flux. This upward flux is driven by the evapotranspiration of plant roots. Zone II, occurring from approximately 35 to $90 \mathrm{~m}$, is a static region with no liquid flux. Zone III consists of a region where downward liquid flux is driven by gravity. The Zone I region of upward flux coupled with the Zone II static region make the potential for downward transmission of precipitation extremely low (BN, 2006).

\subsubsection{Data Assessment Summary}

A wide range of information is available about physical, chemical, and climate characteristics, as well as facility design, operation, and source materials. These data provide the information necessary to complete performance assessments, perform sensitivity and uncertainty analyses, and evaluate closure options. Model results show that all regulatory objectives are easily met and are not impacted by data limitations, and monitoring data confirm the model. The DQOs provided in Appendix A of this document present detailed information about the CSM, waste inventory, and release and transport parameters, with a discussion of their uncertainty.

\subsection{NEED FOR CORRECTIVE ACTION}

The evaluation of the need for corrective action includes buried waste potentially affecting the public or the environment. Monitoring data, modeling results, and the CSM show that risk associated with No Further Action is negligible; however, the closure units must comply with multiple regulations, including 40 CFR 265, 40 CFR 191, DOE O 435.1, and the FFACO. According to 40 CFR 265, Subpart G, §265.111, "Closure Performance Standard," closure must minimize the need for further maintenance, and control, minimize, or eliminate, to the extent necessary to protect human health and the environment, migration of waste to the groundwater, surface water, or atmosphere (CFR, 2006d). Therefore, corrective action is required. 


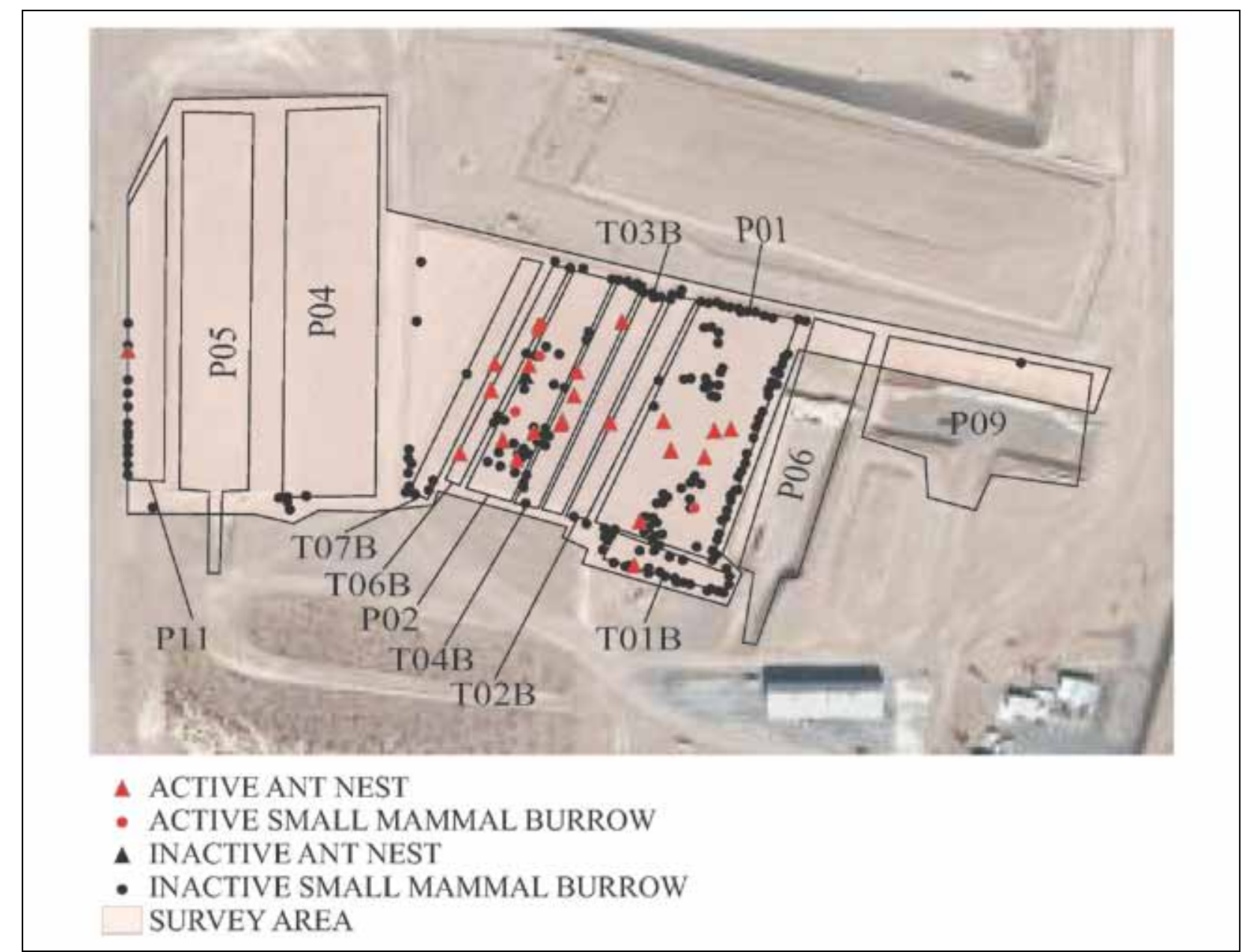

Figure 29. SMall MAMmal AND ANT BurRowing ACTIVITy IN 2007 


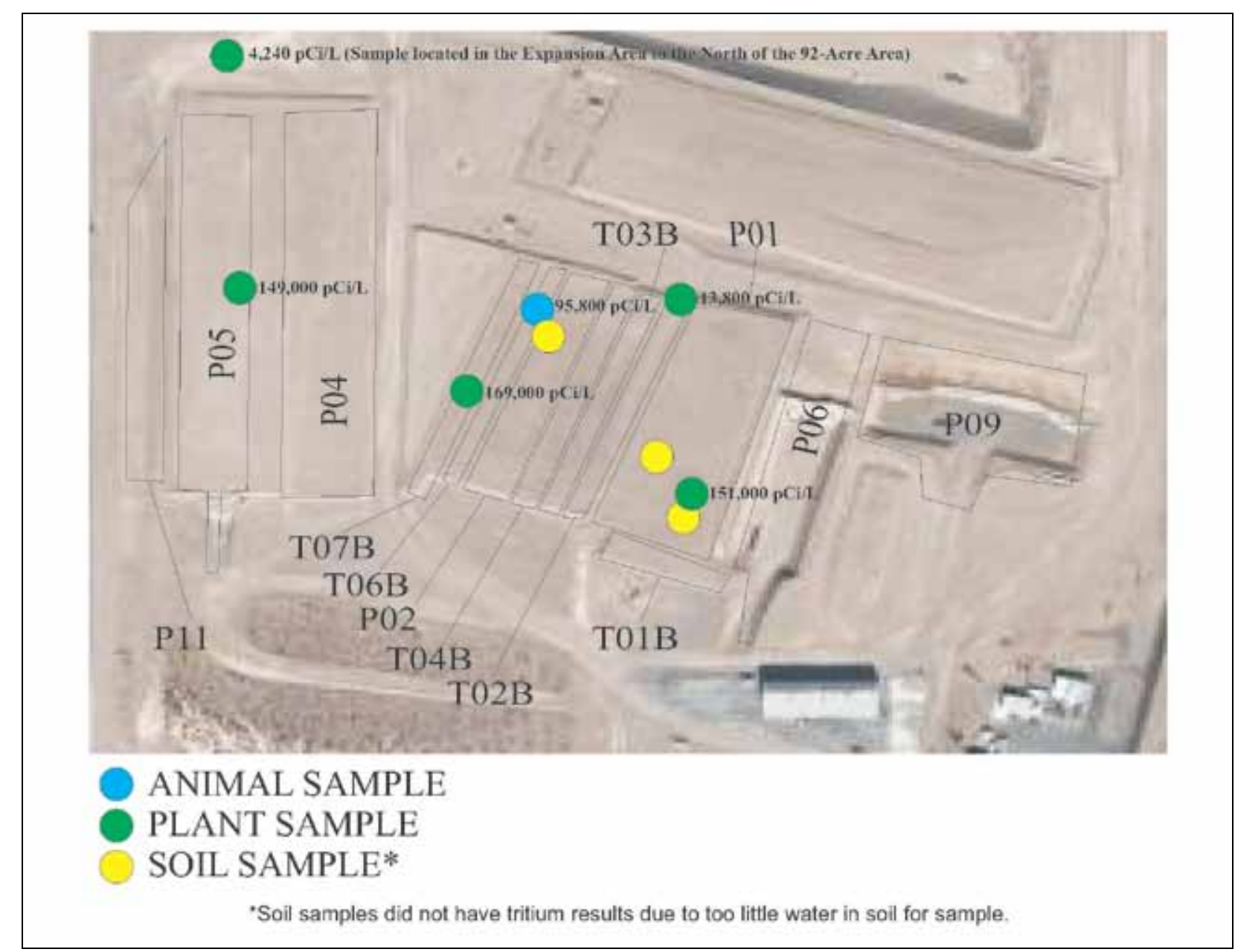

Figure 30. BIOTA Monitoring ResUlts FOR TRITIUM IN 2007 


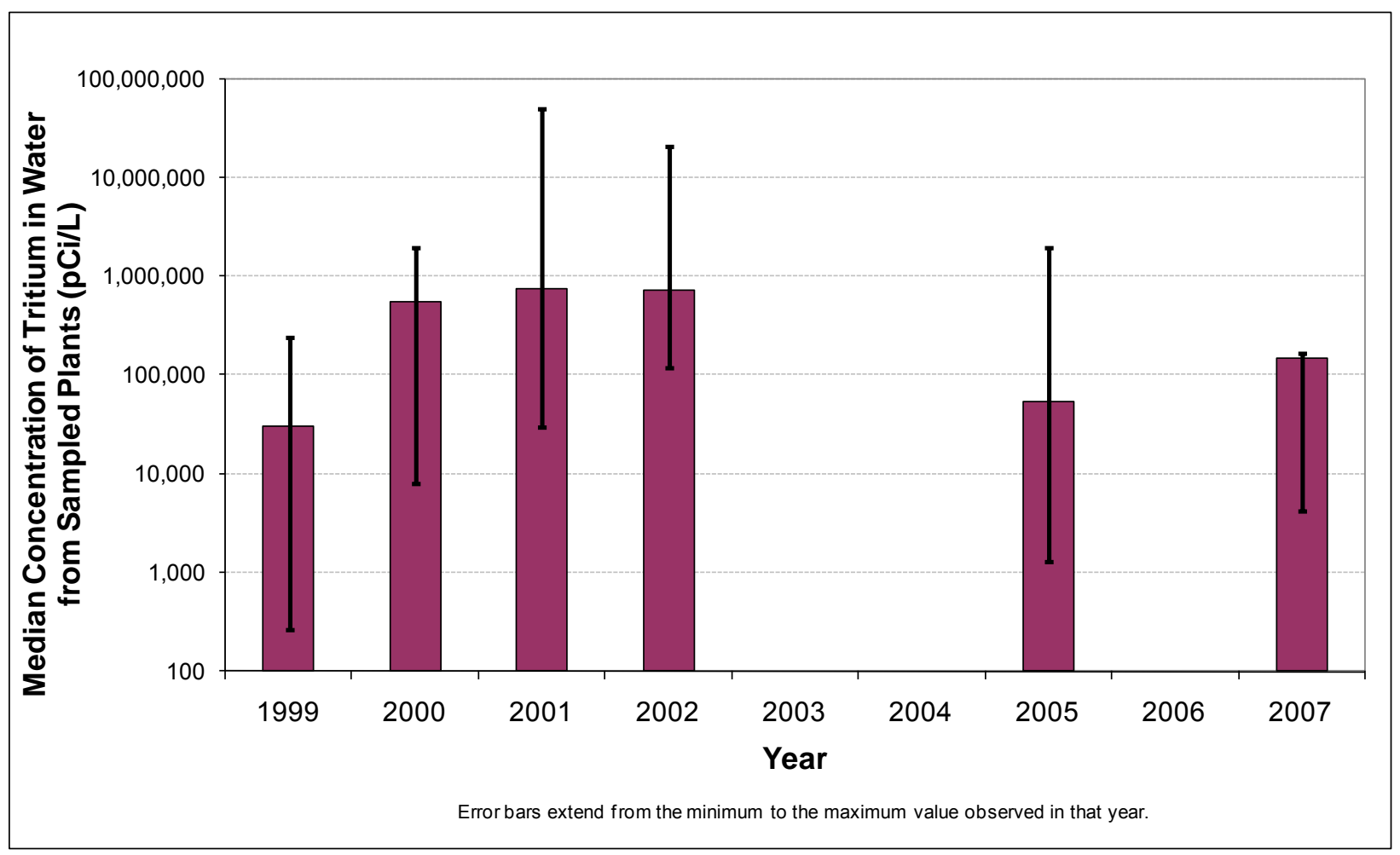

Figure 31. Historical Plant Monitoring Results for Tritium 


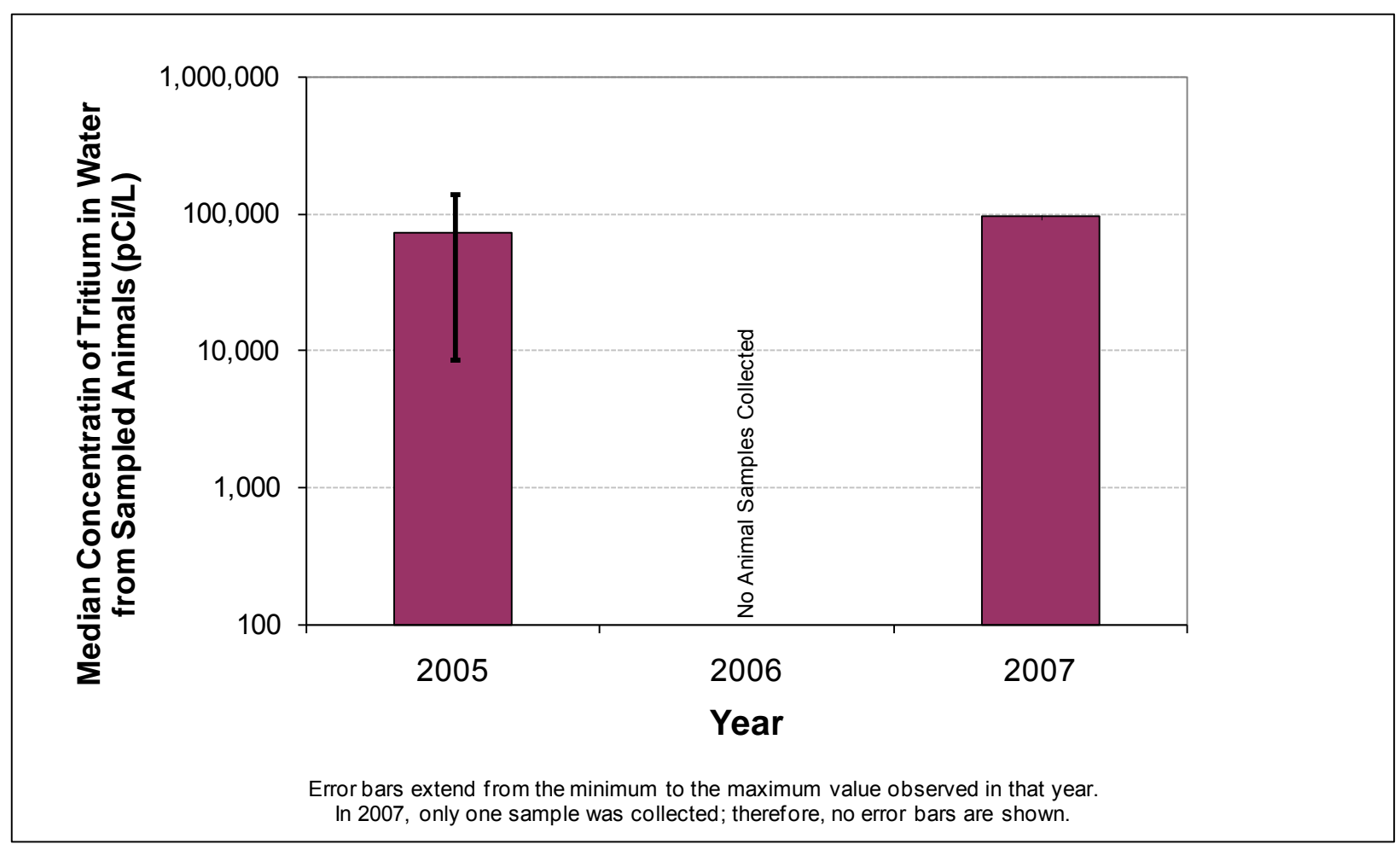

Figure 32. Historical ANIMAL MONITORINg RESUlts FOR TRITIUM 


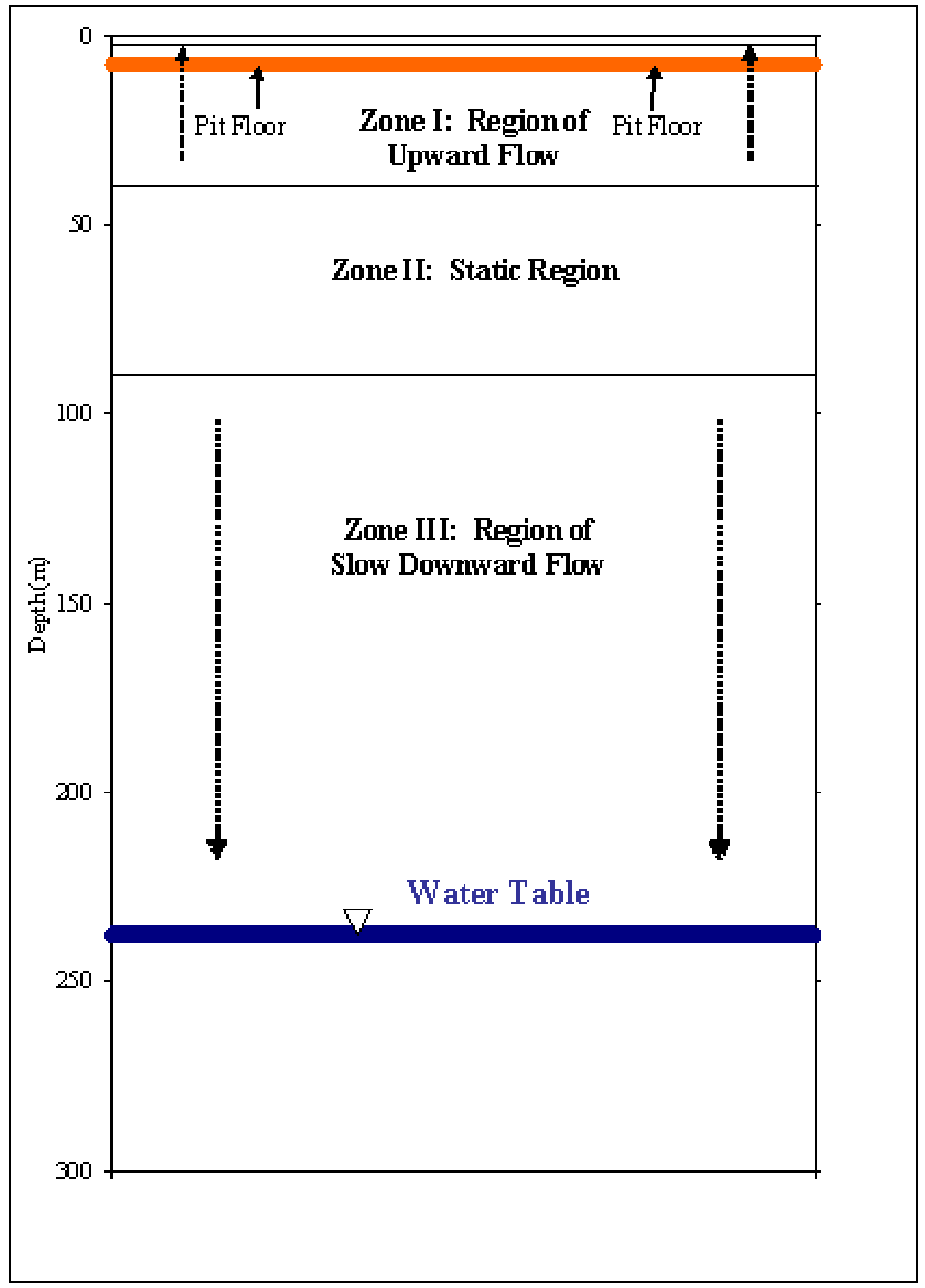

Figure 33. Performance Assessment Model Results 


\subsection{EVALUATION OF ALTERNATIVES}

This section presents the corrective action objectives for the 92-Acre Area, describes the general standards and decision factors used to screen the various CAAs, and develops and evaluates a set of selected CAAs that will meet the corrective action objectives.

\subsection{CORRECTIVE ACTION OBJECTIVES}

The corrective action objective is to ensure that receptors are not subjected to unacceptable risk from an exposure to contamination. As illustrated in Figure 3 and summarized in Table 2, the only viable receptors are NNSS workers and visitors that may be exposed to contaminants through ingestion, inhalation, or direct contact due to inadvertent disturbance into the waste (i.e., excavation) or contact with contaminants brought to the surface by erosion or biota. There is essentially no pathway to offsite residents. It would take more than 50,000 years for water to move from beneath the static region (approximately $90 \mathrm{~m}$ below grade) to the groundwater (approximately $220 \mathrm{~m}$ below grade), and calculated groundwater flow rates are less than $0.15 \mathrm{~m}$ per year. Implementation of the corrective action will ensure that the site will not pose an unacceptable risk to human health and the environment and that site conditions are in compliance with all applicable laws and regulations.

\subsection{SCREENING CRITERIA}

The screening criteria used to evaluate and select the preferred CAAs are identified in the U.S. Environmental Protection Agency (EPA) Guidance on RCRA Corrective Action Decision Documents (EPA, 1991) and the Final RCRA Corrective Action Plan (EPA, 1994). The CAAs are evaluated based on four general corrective action standards and five remedy selection decision factors. The CAAs must meet the four general corrective action standards to be selected for evaluation using the remedy selection decision factors.

The four general corrective action standards are as follows:

- Protection of human health and the environment

- Compliance with media cleanup standards

- Control of the source(s) of the release

- Compliance with applicable federal, state, and local standards for waste management

If a CAA does not meet one or more of the four general corrective action standards listed above, the CAA is not considered for further evaluation. If a CAA meets all four general corrective action standards listed above, the CAA is evaluated based on the following five remedy selection decision factors:

- Short-term reliability and effectiveness

- Reduction of toxicity, mobility, and/or volume

- Long-term reliability and effectiveness

- Feasibility

- Cost 


\subsubsection{Corrective Action Standards}

The following sections describe the four general corrective action standards used to determine whether the CAAs will be considered for further evaluation.

\subsubsection{Protection of Human Health and the Environment}

Protection of human health and the environment is a general mandate of the RCRA statute (EPA, 1994). This mandate requires that the corrective action include any necessary protective measures. These measures may or may not be directly related to media cleanup, source control, or management of waste. The CAAs are evaluated for the ability to protect human health and the environment.

\subsubsection{Compliance with Media Cleanup Standards}

The CAAs are evaluated for the ability to meet the proposed media cleanup standards.

\subsubsection{Control of the Source(s) of the Release}

The CAAs are evaluated for the ability to control further environmental degradation by controlling or eliminating additional releases that may pose a threat to human health and the environment.

\subsubsection{Compliance with Applicable Federal, State, and Local Standards for Waste Management}

The CAAs are evaluated for the ability to be conducted in accordance with applicable federal and state regulations.

\subsubsection{Remedy Selection Decision Factors}

The following sections describe the five remedy selection decision factors used to evaluate the CAAs that meet all four general corrective action standards.

\subsubsection{Short-Term Reliability and Effectiveness}

Each CAA is evaluated with respect to its effects on human health and the environment during implementation of the selected corrective action. The following factors are addressed for each alternative:

- Protection of the community from potential risks associated with implementation, such as fugitive dusts, transportation of waste, or explosion

- Protection of workers during implementation

- Environmental impacts that may result from implementation

- The time required to achieve the corrective action objectives

\subsubsection{Reduction of Toxicity, Mobility, and/or Volume}

Each CAA is evaluated for its ability to reduce the toxicity, mobility, and/or volume of the contaminated media. Reduction in toxicity, mobility, and/or volume refers to changes in one or more characteristics of the contaminated media by the use of corrective measures that decrease the inherent threats associated with those media. 


\subsubsection{Long-Term Reliability and Effectiveness}

Each CAA is evaluated in terms of risk remaining at the site after the CAA has been implemented. The primary focus of this evaluation is on the extent and effectiveness of the control that may be required to manage the risk posed by transportation, treatment, and disposal of excavated waste.

\subsubsection{Feasibility}

The feasibility criterion addresses the technical and administrative feasibility of implementing a CAA and the availability of services and materials needed for implementation. Each CAA is evaluated for the following criteria:

- Construction and Operation - The feasibility of implementing a CAA given the existing site-specific conditions

- Administrative Feasibility - The administrative activities needed to implement the CAA (e.g., permits, URs, public acceptance, rights-of-way, offsite approval)

- Availability of Services and Materials - The availability of adequate offsite and onsite treatment, storage capacity, disposal services, necessary technical services and materials, and prospective technologies for each CAA

\subsubsection{Cost}

Costs for each alternative are estimated for comparison purposes only. The cost estimate for each CAA is provided in Appendix B of this document. The following is a brief description of each component:

- Capital Costs - These include direct costs for material, labor, construction material, equipment purchase and rental, excavation and backfilling, sampling and analysis, waste disposal, demobilization, and health and safety measures. Indirect costs are separate and not included in the estimates.

- Operation and Maintenance - These costs are separate and include labor, training, sampling and analysis, maintenance material, utilities, and health and safety measures. These costs are not included in the estimates.

\subsection{Development of Corrective Action Alternatives}

This section identifies and summarizes the viable CAAs considered for the 92-Acre Area. Based on the review of existing data, future use, and current operations, the following alternatives have been developed for consideration:

- Alternative 1 - No Further Action

- Alternative 2 - Clean Closure

- Alternative 3 - Closure in Place with Administrative Controls

- Alternative 4 - Closure in Place with Administrative Controls with Removal of TRU Waste from Trench T04A 


\subsubsection{Alternative 1 - No Further Action}

Alternative 1 is the baseline with which to compare and assess the other CAAs and their ability to meet the corrective action standards. The No Further Action alternative includes continuing the current monitoring activities at the 92-Acre Area, as described in Section 2.1, and maintaining the current operational covers.

\subsubsection{Alternative 2 - Clean Closure}

Alternative 2 involves the excavation, transportation, certification, and disposal of all waste present in the entire 92-Acre Area. Waste would be transported to and disposed at another (unspecified) location.

\subsubsection{Alternative 3 - Closure in Place with Administrative Controls}

Alternative 3 includes the administrative activities and costs associated with implementing a UR to restrict inadvertent contact with the waste by prohibiting any activity that would cause significant exposure of receptors to contaminants. The Closure in Place with Administrative Controls alternative includes leaving all buried waste in place, constructing an engineered cover over the 92-Acre Area, installing UR warning signs and concrete monuments, and implementing post-closure monitoring.

\subsubsection{Alternative 4 - Closure in Place with Administrative Controls with Removal of TRU Waste from Trench T04A}

Alternative 4 includes excavation and disposal of TRU waste that was inadvertently disposed in trench T04A in addition to implementing a UR for remaining waste. This alternative includes sorting the waste in trench T04A; packaging the TRU waste from the trench; returning the remaining waste to the trench; certifying, transporting, and disposing of the TRU waste; constructing an engineered cover over the 92-Acre Area; installing UR warning signs and concrete monuments; and implementing post-closure monitoring.

\subsection{EVAluation AND COMPARISON OF Alternatives}

Each CAA presented in Section 3.3 has been evaluated based on the four general corrective action standards described in Section 3.2.1. Table 3 presents the results of this evaluation. If a CAA does not comply with all of the general corrective action standards, it is not considered for further evaluation. Alternatives 1,3, and 4 comply with all of the general corrective action standards and have been further evaluated.

Alternative 2, Clean Closure, will not be considered for further evaluation because it does not comply with the first corrective action standard, protection of human health and the environment. This alternative would reduce the localized risk to the environment, but it would not reduce the overall risk because the waste and associated risk would simply be moved to another disposal location. This alternative would present significant risk to workers during excavation, repackaging, transportation, and placement of waste, with no overall benefit or reduction of risk to the environment. Therefore, the Clean Closure alternative will not be considered for further evaluation. 


\section{Table 3. Evaluation of General Corrective Action Standards}

\begin{tabular}{|c|c|c|}
\hline \multicolumn{3}{|r|}{ Alternative 1 - No FURTHER ACTION } \\
\hline Standard & Comply & $\begin{array}{l}\text { Explanation } \\
\end{array}$ \\
\hline $\begin{array}{l}\text { Protection of human health } \\
\text { and the environment }\end{array}$ & Yes & $\begin{array}{l}\text { The current monitoring network assures the protection of human health and the } \\
\text { environment. }\end{array}$ \\
\hline $\begin{array}{l}\text { Compliance with media } \\
\text { cleanup standards }\end{array}$ & Yes & Waste will not be removed, and NNSS workers will not be exposed to excavation risks. \\
\hline $\begin{array}{l}\text { Control of the source(s) of } \\
\text { the release }\end{array}$ & Yes & $\begin{array}{l}\text { Characterization and monitoring show there is no migration beyond the waste cells, and } \\
\text { current monitoring assures future migration will not occur. }\end{array}$ \\
\hline $\begin{array}{l}\text { Compliance with federal, } \\
\text { state, and local standards } \\
\text { for waste management }\end{array}$ & Yes & This alternative will not generate waste. \\
\hline \multicolumn{3}{|c|}{ Alternative 2 - Clean Closure, All Waste in the 92-ACre Area } \\
\hline Standard & Comply & $\begin{array}{l}\text { Explanation } \\
\end{array}$ \\
\hline $\begin{array}{l}\text { Protection of human health } \\
\text { and the environment }\end{array}$ & No & $\begin{array}{l}\text { Workers will be exposed to unacceptable risk, with increased risk to the community } \\
\text { from transport of waste. }\end{array}$ \\
\hline $\begin{array}{l}\text { Compliance with media } \\
\text { cleanup standards }\end{array}$ & Yes & Waste will be removed. \\
\hline $\begin{array}{l}\text { Control of the source(s) of } \\
\text { the release }\end{array}$ & Yes & Waste will be removed. \\
\hline $\begin{array}{l}\text { Compliance with federal, } \\
\text { state, and local standards } \\
\text { for waste management }\end{array}$ & Yes & Excavated waste can be managed in compliance with all standards. \\
\hline \multicolumn{3}{|c|}{ Alternative 3 - Closure in Place with Administrative Controls } \\
\hline Standard & Comply & Explanation \\
\hline $\begin{array}{l}\text { Protection of human health } \\
\text { and the environment }\end{array}$ & Yes & $\begin{array}{l}\text { A UR and post-closure monitoring will be implemented to protect receptors from } \\
\text { exposure to waste. }\end{array}$ \\
\hline $\begin{array}{l}\text { Compliance with media } \\
\text { cleanup standards }\end{array}$ & Yes & Waste will remain in place, and NNSS workers will not be exposed to excavation risks. \\
\hline $\begin{array}{l}\text { Control of the source(s) of } \\
\text { the release }\end{array}$ & Yes & $\begin{array}{l}\text { Characterization and monitoring show there is no migration beyond the waste cells, and } \\
\text { post-closure monitoring will be implemented to assure future migration will not occur. }\end{array}$ \\
\hline $\begin{array}{l}\text { Compliance with federal, } \\
\text { state, and local standards } \\
\text { for waste management }\end{array}$ & Yes & This alternative will not generate waste. \\
\hline \multicolumn{3}{|c|}{$\begin{array}{c}\text { Alternative } 4 \text { - Closure in PlaCe WITH AdMinistrative CONTROLS } \\
\text { WITH REMOVAl OF TRU WASTE FROM TRENCH T04A }\end{array}$} \\
\hline Standard & Comply & $\begin{array}{l}\text { Explanation } \\
\end{array}$ \\
\hline $\begin{array}{l}\text { Protection of human health } \\
\text { and the environment }\end{array}$ & Yes & $\begin{array}{l}\text { TRU waste will be removed from Trench T04A, and a UR and post-closure monitoring } \\
\text { will be implemented to protect receptors from exposure to waste. }\end{array}$ \\
\hline $\begin{array}{l}\text { Compliance with media } \\
\text { cleanup standards }\end{array}$ & Yes & $\begin{array}{l}\text { Most of the waste will remain in place, but NNSS workers will be exposed to waste } \\
\text { removed from Trench T04A. }\end{array}$ \\
\hline $\begin{array}{l}\text { Control of the source(s) of } \\
\text { the release }\end{array}$ & Yes & $\begin{array}{l}\text { Characterization and monitoring show there is no migration beyond the waste cells, and } \\
\text { post-closure monitoring will be implemented to assure future migration will not occur. }\end{array}$ \\
\hline $\begin{array}{l}\text { Compliance with federal, } \\
\text { state, and local standards } \\
\text { for waste management }\end{array}$ & Yes & Excavated waste can be managed in compliance with all standards. \\
\hline
\end{tabular}

NNSS: Nevada National Security Site

TRU: transuranic

UR: use restriction 
Each of the remaining CAAs has been further evaluated based on the five remedy selection decision factors described in Section 3.2.2. Table 4 presents this evaluation. For each remedy selection decision factor, the CAAs are ranked relative to one another. The CAA with the least desirable impact on the remedy selection decision factor is given a ranking of 1. CAAs with increasing desirable impacts on the remedy selection decision factor receive increasing rank numbers. CAAs with equal impact on the remedy selection decision factor receive an equal ranking number.

For example, for the remedy selection decision factor of "feasibility," the CAA with the least desirable impact (in this case, the CAA that is the least feasible) is given a ranking of 1 , and the CAA with the most desirable impact (in this case, the CAA that is the most feasible) is given a ranking of 3. For the remedy selection decision factor of "cost," the CAA with the least desirable impact (in this case, the CAA with the highest cost) is given a ranking of 1 , and the CAA with the most desirable impact (in this case, the CAA with the lowest cost) is given a ranking of 3 .

The total score presented in Table 4 is the sum of the remedy selection decision factor rankings for each CAA. The CAA with the highest total score is selected as the preferred CAA. This evaluation shows that the CAA with the highest total score has the most desirable overall impact on short-term reliability and effectiveness; reduction of toxicity, mobility, and/or volume; long-term reliability and effectiveness; feasibility; and cost. 


\section{TABle 4. Evaluation OF REMEDy SELECTION DECISION FACTORS}

\begin{tabular}{|c|c|c|}
\hline \multicolumn{3}{|c|}{ Alternative 1 - No FURTHER ACTION } \\
\hline Factor & Rank & Explanation \\
\hline Short-term reliability and effectiveness & 2 & $\begin{array}{l}\text { Reliable and effective in providing protection of workers, the community, and } \\
\text { the environment by continuing current monitoring activities }\end{array}$ \\
\hline $\begin{array}{l}\text { Reduction of toxicity, mobility, and/or } \\
\text { volume }\end{array}$ & 2 & $\begin{array}{l}\text { Does not reduce toxicity or mobility of buried waste, but will not generate } \\
\text { excavation waste volumes }\end{array}$ \\
\hline Long-term reliability and effectiveness & 1 & $\begin{array}{l}\text { Current ongoing monitoring is reliable in the long term, but less reliable than } \\
\text { Alternatives } 3 \text { and } 4\end{array}$ \\
\hline Feasibility & 3 & Most easily implemented alternative \\
\hline Cost & 3 & Involves low cost for maintaining the current monitoring system \\
\hline Score & 11 & \\
\hline \multicolumn{3}{|c|}{ Alternative 2 - Clean Closure, All WASte in the 92-ACre Area } \\
\hline Factor & Rank & Explanation \\
\hline \multicolumn{3}{|c|}{ This CAA did not meet the general corrective action standards and was therefore not further evaluated. } \\
\hline \multicolumn{3}{|c|}{ Alternative 3 - Closure in Place with Administrative Controls } \\
\hline Factor & Rank & Explanation \\
\hline Short-term reliability and effectiveness & 3 & $\begin{array}{l}\text { Most reliable and effective in providing protection of workers, the } \\
\text { community, and the environment by preventing contact with buried waste }\end{array}$ \\
\hline $\begin{array}{l}\text { Reduction of toxicity, mobility, and/or } \\
\text { volume }\end{array}$ & 3 & $\begin{array}{l}\text { Reduces toxicity and mobility of buried waste through construction of } \\
\text { engineered cover and will not generate excavation waste volumes }\end{array}$ \\
\hline Long-term reliability and effectiveness & 2 & $\begin{array}{l}\text { Reliable in the long term by providing increased protection of human health } \\
\text { and the environment by preventing contact with buried waste and } \\
\text { implementing post-closure monitoring }\end{array}$ \\
\hline Feasibility & 2 & Easily implemented but requires implementation of post-closure monitoring \\
\hline Cost & 2 & $\begin{array}{l}\text { Involves lower cost for construction of an engineered cover and post-closure } \\
\text { monitoring }\end{array}$ \\
\hline Score & 12 & \\
\hline \multicolumn{3}{|c|}{$\begin{array}{c}\text { Alternative } 4 \text { - Closure in Place With Administrative ConTRols } \\
\text { WITH ReMOVAL OF TRU WASTE FROM TRENCH T04A }\end{array}$} \\
\hline Factor & Rank & Explanation \\
\hline Short-term reliability and effectiveness & 1 & $\begin{array}{l}\text { Of the alternatives that complied with all of the general corrective action } \\
\text { standards, involves the highest risk to workers, the community, and the } \\
\text { environment during excavation, transport, and disposal of waste }\end{array}$ \\
\hline $\begin{array}{l}\text { Reduction of toxicity, mobility, and/or } \\
\text { volume }\end{array}$ & 1 & $\begin{array}{l}\text { Could decrease mobility; however, will generate large excavation waste } \\
\text { volumes }\end{array}$ \\
\hline Long-term reliability and effectiveness & 2 & $\begin{array}{l}\text { Increases long-term protection of human health and the environment because } \\
\text { TRU waste will be removed; however, TRU waste does not pose a risk to } \\
\text { human health and the environment in its current configuration, so this is } \\
\text { equally as reliable as Alternative } 3\end{array}$ \\
\hline Feasibility & 1 & Involves the most complicated implementation \\
\hline Cost & 1 & $\begin{array}{l}\text { Involves the highest cost for excavation of TRU waste, construction of an } \\
\text { engineered cover, and future monitoring for remaining waste }\end{array}$ \\
\hline Score & 6 & \\
\hline
\end{tabular}

TRU: transuranic 
92-Acre Area and CAU 111 CADD/CAP

Section: Evaluation of Alternatives

Revision: 1

Date: November 2010

THIS PAGE INTENTIONALLY LEFT BLANK 


\subsection{RECOMMENDED ALTERNATIVE}

Alternative 3, Closure in Place with Administrative Controls, is the preferred CAA for the 92-Acre Area. The preferred CAA was evaluated on technical merits with focus on performance, reliability, feasibility, safety, and cost. The Closure in Place with Administrative Controls alternative was judged to meet all requirements for the technical components evaluated; meets all applicable federal and state regulations for closure of the site, including 40 CFR 265, 40 CFR 191, and DOE O 435.1; and will minimize potential future exposure pathways to the buried waste at the site.

Selection of this CAA is consistent with past practices for sites that contain buried waste where the removal of buried waste is not feasible. For example, CAU 92, Area 6 Decon Pond Facility, a RCRA unit consisting of an unlined pond used for the disposal of untreated liquid effluent from the laundering of radioactively contaminated clothing and decontamination of heavy equipment, was closed in place. A Corrective Measures Study found that this was the most cost-effective method of meeting the closure objectives and complying with regulatory requirements (DOE, 1997). CAU 110, Area 3 RWMS U-3ax/bl Disposal Unit, was closed in place with an engineered RCRA alternative cover designed to accommodate differential subsidence. The cover is a vegetated natural alluvium mono-layer cover. It was determined that the disposal unit could accommodate infiltration, evaporation, and plant and animal activity in its present state and keep buried waste contained (U.S. Department of Energy, National Nuclear Security Administration Nevada Operations Office [NNSA/NV], 1999).

Closure activities will include the following:

- Constructing an engineered cover over the 92-Acre Area

- Installing UR warning signs, concrete monuments, and subsidence survey monuments

- Establishing vegetation on the cover

- Implementing a UR

- Implementing post-closure inspections and monitoring

There are several engineered cover options available, including, but not limited to, clay covers, native soil covers, multi-layer covers, and asphalt covers. Numerous studies have evaluated the performance of each of these. In arid environments, the native soil evapotranspiration cover has proven to be the most protective with long-term stability and effectiveness (Reynolds Electrical and Engineering Company, Inc, 1994; Dwyer et al., 1999; DOE, 2000; Madalinski et al., 2003). An extensive evaluation of cover alternatives was performed for CAU 110, Area 3 RWMS U-3ax/bl Disposal Unit, a historic RCRA disposal unit located in Area 3 of the NNSS. An evapotranspiration cover was selected from nine cover options (NNSA/NV, 2000). The CAU 110 cover has been demonstrated to be very effective since its installation in 2000 . Consistent with industry experience and the successful cover at CAU 110, an evapotranspiration cover has been selected as the appropriate engineered cover for the 92-Acre Area.

To evaluate closure alternatives and demonstrate compliance with federal regulations, an optimization of the closure cover design was performed and tested with the current performance assessment model to confirm that all performance objectives can be met. The optimization included a quantitative analysis of closure cover thickness with respect to protection of human health and the environment. Five discrete cover thickness options ranging from 2.5 to $4.5 \mathrm{~m}$ were evaluated (Shott and Yucel, 2009). 
The optimum cover thickness that maintains doses as low as reasonably achievable (ALARA) was determined to be $2.5 \mathrm{~m}$. A $2.5-\mathrm{m}$ closure cover can meet all applicable regulatory requirements and maintain radionuclide releases ALARA (Shott and Yucel, 2009).

Figure 34 illustrates that increasing the cover thickness above $2.5 \mathrm{~m}$ provides no significant increase in protection of human health or the environment. There is no significant decrease in dose to the public, which is shown in Figure 34 in units of person-Sieverts (per-Sv) (Shott and Yucel, 2009). In fact, increasing cover thickness beyond this optimum value would increase the risk to the workers who construct the cover due to unnecessary exposure to standard industrial risks associated with heavy equipment operation during soil excavation, transportation, and placement. 


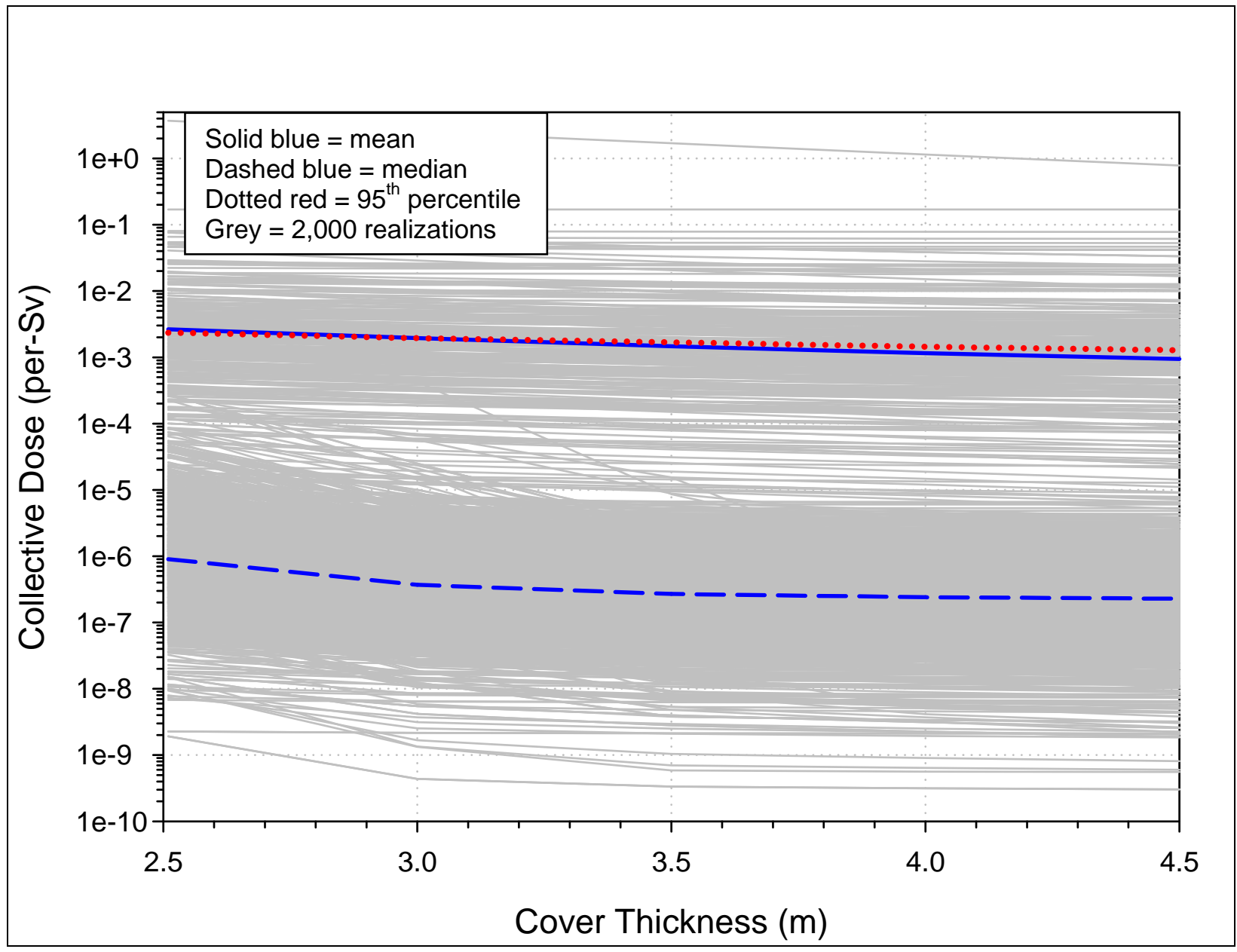

Figure 34. Collective Dose Versus Cover Thickness 
92-Acre Area and CAU 111 CADD/CAP

Section: Recommended Alternative

Revision: 1

Date: November 2010

THIS PAGE INTENTIONALLY LEFT BLANK 


\subsection{DETAILED STATEMENT OF WORK}

The following sections provide a description of the preferred CAA, identify the QA/QC requirements, describe waste management activities, present activities that will be completed to confirm the corrective actions, and identify the permits required to complete the corrective actions.

\subsection{Preferred Corrective Action Alternative}

The preferred CAA for the 92-Acre Area, as evaluated in Section 3.0 and identified in Section 4.0, is Closure in Place with Administrative Controls. A 2.5-m-thick engineered evapotranspiration cover will be installed over the 92-Acre Area. The engineering drawings, specifications, and calculations are included as Appendix $\mathrm{C}$ of this document.

The cover has been designed to meet the following requirements, according to 40 CFR 265, Subpart N, §265.310, "Closure and Post-Closure Care" (CFR, 2006d):

- Provide long-term minimization of migration of liquid through the landfill

- Function with minimum maintenance

- Promote drainage and minimize erosion of the cover

- Accommodate settling and subsidence to maintain the cover's integrity

\subsubsection{Site Preparation}

The site will be cleared and grubbed prior to installation of the cover. All aboveground electrical panels, monitoring devices, and junction boxes, except as noted in the engineering design, will be removed. The existing chain link and smooth wire fencing will be removed. The GCD boreholes will be backfilled. The vadose monitoring cabinets on Pit 3, Pit 4, and Pit 5 will be modified and relocated on the new surface. All vadose monitoring boreholes will be cut at least $2 \mathrm{ft}$ below the surface and filled with concrete except as noted in the engineering design. All existing underground water, sewer, and communication lines will remain in place. Underground power lines will be abandoned in place. The siren pole that is currently located near Pit 1 will be deactivated and removed.

\subsubsection{Engineered Cover Construction}

With the exception of three active pits (P03, P06, and P09), all trenches and pits in the 92-Acre Area have current operational covers approximately $2.4 \mathrm{~m}$ thick; therefore, construction of the cover over these units will consist of augmenting the current operational covers to the final thickness, grade, and slope required by the final engineering design. For the open pits, the backfill will be placed in 18-inch maximum loose lifts and compacted to between 78 and 85 relative compaction according to American Society for Testing and Materials (ASTM) Standard D698, not to exceed a dry density of $1.65 \mathrm{~g} / \mathrm{cm}^{3}$ or $103 \mathrm{lb} / \mathrm{ft}^{3}$. This will ensure the required soil compaction for vegetation establishment without exceeding growth-limiting bulk density values to the detriment of vegetation.

An existing stockpile of clean soil located at the site will be used for backfill and for construction of the cover. The soil does not require conditioning prior to use, as it meets the engineering specifications. To minimize the volume of soil needed for construction of the cover while 
promoting drainage and minimizing erosion, the cover will consist of five smaller covers separated by drainage channels. Riprap with filter fabric will be installed in parts of the channels to minimize scour. The typical side slope of the covers will be 3:1, maximum.

\subsubsection{Subsidence Monument Installation}

A total of 52 subsidence survey monuments will be installed on the covers. Each monument consists of a 12-inch-diameter plate fitted with a small riser and brass cap. The 12-inch diameter plate is placed within the cover, and the brass cap protrudes into a 6-inch-diameter frame and lid to provide access for the surveyors. The top of the frame and lid is set at the top of the grade.

\subsubsection{Temporary Erosion and Sediment Control and Vegetation Establishment}

Temporary erosion and sediment controls, liquid soil stabilizers such as a polymer emulsion or equivalent, are specified for the covers during the 5- to 6-month period between completion of grading activities and initiation of vegetation seeding and straw mulch application, to address wind and water erosion concerns.

The cover will be seeded with a mixture of native plant species. The vegetation will minimize wind and water erosion and remove water from the cover through evapotranspiration. The top 12 to 18 inches of soil will be prepared to alleviate soil compaction and provide a suitable environment for the establishment of the seeds. Straw mulch will be spread and crimped into the soil after seeding to protect from erosion and conserve soil moisture. Irrigation will initially be used to augment precipitation and provide optimal conditions to ensure successful seed germination. Irrigation will be minimized to limit infiltration through the cover. Additional details are included in Construction Specifications.

\subsubsection{Fence Installation}

A fence is not required around the 92-Acre Area. A 3-strand wire fence currently exists around the entire RWMS, and this fence serves to enhance access control to the site as a best management practice. Quarterly post-closure inspections, as described in Section 7.1, will identify any animal burrows that may affect the integrity of the cover. These animal burrows will be backfilled within 60 calendar days of discovery.

\subsubsection{Use Restriction Implementation}

UR warning signs and concrete monuments will be installed according to the FFACO Use Restriction Posting Guidance to delineate the UR area (FFACO, 2003). Concrete monuments that currently mark the boundaries of disposal units and measure 2 feet by 2 feet by 5 feet high will be re-installed along the perimeter of the UR area, and UR warning signs will be attached to the monuments. A UR will be implemented to prohibit any unauthorized intrusive activity. A final survey plat will be prepared and certified by a professional land surveyor. Post-closure inspections and monitoring will be implemented according to the requirements in Section 7.0.

\subsection{Construction Quality Assurance/Quality Control}

Construction activities will be self performed; therefore, a construction quality control plan is not required. However, construction quality assurance (CQA) activities will be performed by an 
independent CQA team, led by a Nevada Licensed Professional Engineer. The CQA team lead will develop the CQA plan, be responsible for all CQA activities, and certify the closure; the CQA team members, who report to the CQA lead, will perform the field and laboratory tests, archive samples, monitor all construction activities, and perform the as-built survey.

Engineering drawings, specifications, and calculations are included as Appendix C.

\subsubsection{Construction Field Sample Collection Activities}

Additional details on construction field sample requirements are included in the engineering specifications in Appendix C. Field activities will include in situ testing for soil classification (ASTM D2488), moisture and density (ASTM D1556 and D6938), and obtaining Shelby-tube samples for laboratory tests of moisture/density characteristics (ASTM D698 and ASTM D2216). Field soil classification will be performed once per source of fill material or subgrade material. In-place moisture and density tests will be performed at a frequency of five per acre per lift. The tests and test frequencies may be subject to revision per the approved CQA plan, developed based on the construction specifications and the design.

\subsubsection{Construction Quality Assurance/Laboratory Tests}

Laboratory tests will include water content determination (ASTM D2216) at a frequency of five per acre, and moisture/density characteristics (ASTM D698) at a frequency of once per source of fill material source. The test frequencies may be subject to revision per the approved CQA plan, developed based on the construction specifications and the design.

\subsection{WASTE MANAGEMENT}

Waste is not expected to be generated during closure of the 92-Acre Area. However, if generated, all waste will be managed and disposed according to applicable federal and state regulations and company waste management procedures.

\subsubsection{Waste Minimization}

If waste is generated, care will be taken to properly characterize and segregate waste streams to avoid the generation of additional waste.

\subsection{CONFIRMATION OF CORRECTIVE ACTIONS}

The corrective actions will be confirmed by visual inspection and photographic documentation of the final site conditions, and the cover will be as-built surveyed. The final survey plat that will be prepared and certified by a professional land surveyor will be included in the Closure Report for the site. In addition, a registered professional engineer will review this Closure Plan and sign a certification of closure that states that the site has been closed in accordance with the specifications of this plan. The certification of closure will be included in the Closure Report for the site. DQIs are not applicable to this project because verification samples will not be collected for site closure. 


\subsection{Permits}

Prior to beginning closure activities, planning documents and permits will be prepared. These documents will include a National Environmental Policy Act (NEPA) Checklist, a Real Estate/ Operations Permit (REOP), Radiological Work Permits (RWPs), excavation permits, and blind penetration permits. After closure activities are complete, a request for the modification of RCRA Permit NEV HW0021 to incorporate the requirements for post-closure monitoring will be submitted to NDEP (NDEP, 2005).

\subsubsection{National Environmental Policy Act Checklist}

A NEPA Checklist will be completed prior to all closure activities at the site to ensure closure activities will follow all applicable federal, state, and local laws, regulations, and permits regarding protection of the environment. A new borrow pit will not be developed for closure of the site because an existing stockpile of clean soil is located at the site for backfill and construction of the cover; therefore, an additional NEPA evaluation will not be required.

\subsubsection{Real Estate/Operations Permit}

A REOP will be obtained prior to beginning closure activities. The permit will establish NNSA/NSO as the prime authority possessing control of the site.

\subsubsection{Radiological Work Permit}

RWPs will be implemented when radiological conditions require, as determined by Health Physics. RWPs will inform workers of the specific personal protective equipment necessary to protect them while performing their tasks and identify site-specific controls. The workers will be required to sign RWPs and acknowledge understanding of the requirements before entry into any radiologically controlled area. RWPs will be maintained by the Radiological Control Technician at the entrance to the radiologically controlled area. All site workers will be required to be Radiation Worker II-trained to perform work within a radiologically controlled area.

\subsubsection{Utility Clearances, Excavation Permits, and Blind Penetration Permits}

An excavation permit and a blind penetration permit will be obtained prior to beginning land-disturbing activities. These permits require that a utility clearance be performed. A copy of the permit will be available on site throughout the duration of the project.

\subsubsection{Resource Conservation and Recovery Act Permit}

After closure activities are complete, a request for the modification of RCRA Permit NEV HW0021, to incorporate the requirements for post-closure monitoring identified in Section 7.0, will be submitted to NDEP (NDEP, 2005). 


\subsection{SCHEDULE}

According to 40 CFR 265, Subpart G, "Closure and Post-Closure," the following schedule restraints will be adhered to (CFR, 2006d):

- This Closure Plan will be submitted to NDEP at least 180 days prior to the date on which closure is expected to begin.

- NDEP will be notified in writing at least 60 days prior to the date on which closure is expected to begin.

- The public will have 30 days to submit written comments on the plan and request modifications to the plan.

- Closure activities will be completed within 180 days after receiving the final volume of waste or 180 days after approval of this Closure Plan, whichever is later.

- Certification that the facility has been closed in accordance with the specifications in the approved Closure Plan will be submitted to NDEP by registered mail within 60 days of completion of closure following vegetation.

Figure 35 illustrates the schedule for closure of the 92-Acre Area. Pit 3 MWDU is scheduled to receive its final shipment of waste on November 30, 2010. Closure is expected to begin immediately thereafter. Therefore, this Closure Plan must be submitted to NDEP by June 3, 2010, which is 180 days prior to the date on which closure is expected to begin. With the exception of establishing vegetation, closure activities for the entire 92-Acre Area will be completed by May 29, 2011, which is 180 days after the final volume of waste will be received. Seeding of the cover will be conducted in the fall of 2011 to allow plants to become established over the winter. Certification of closure will be submitted to NDEP by July 28, 2011, which is 60 days after closure will be completed. The Closure Report will be prepared after the vegetation is complete. The certificate of closure will be submitted as approved in the Closure Report.

All preparation and field activities are scheduled for completion in 2011. Sufficient flexibility will be incorporated into the field schedule to allow for minor difficulties (e.g., weather, equipment failure). NNSA/NSO shall notify NDEP of any condition or event that may impact the project schedule. 


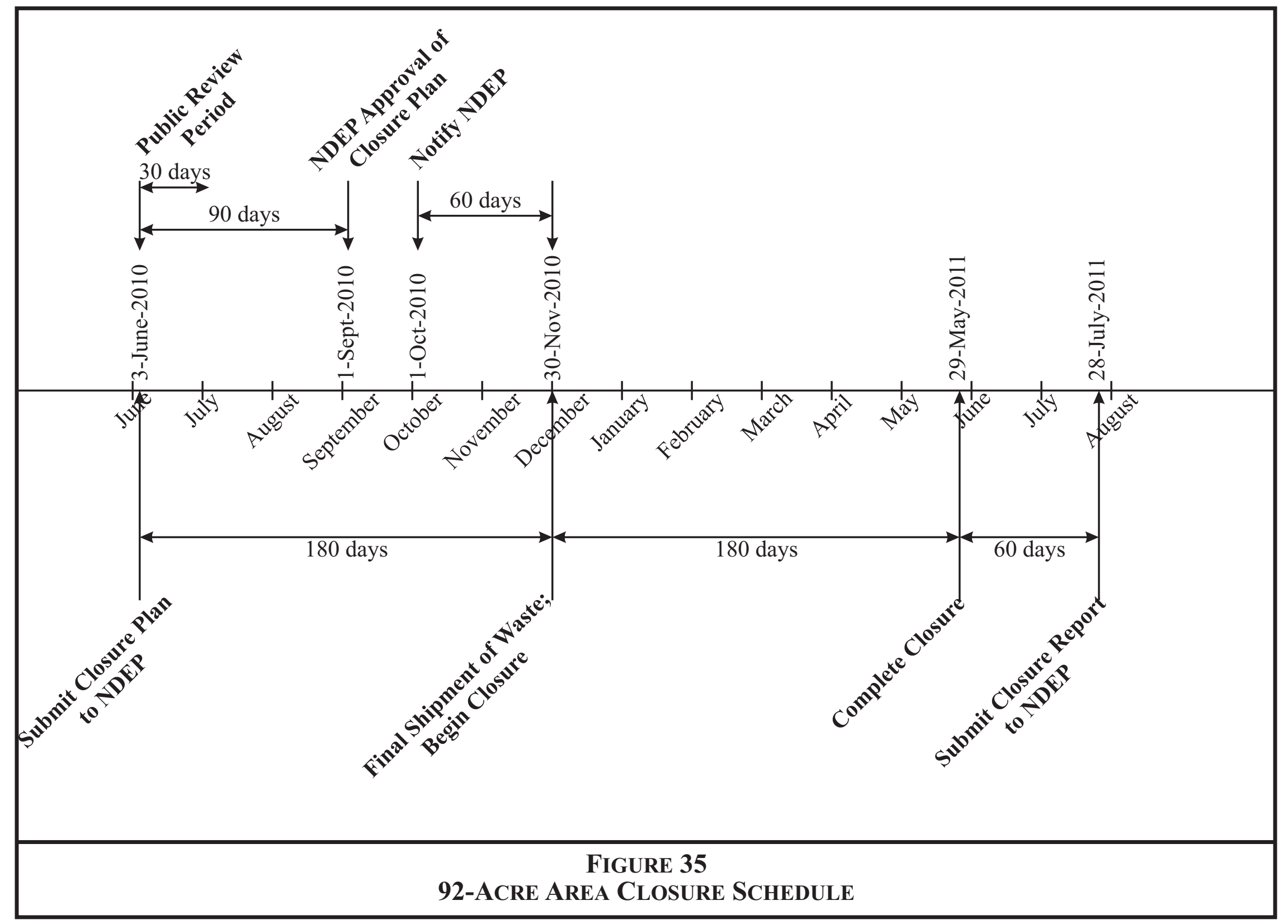


The 92-Acre Area will be closed in place with administrative controls, and a UR will be implemented to prohibit any unauthorized intrusive activities. Post-closure inspections and monitoring will be required. This section serves as the Post-Closure Plan, which is required by 40 CFR 265, for the 92-Acre Area. These requirements will be submitted to NDEP as part of the request for the modification of RCRA Permit NEV HW0021 (NDEP, 2005).

This post-closure plan meets the following requirements of 40 CFR 265, Subpart N, §265.310, "Closure and Post-Closure Care" (CFR, 2006d):

- Maintain the integrity and effectiveness of the cover by making repairs to correct the effects of settling, subsidence, and erosion

- Monitor groundwater quality

- Prevent run-on and runoff from damaging the cover

- Maintain surveyed benchmarks

\subsection{INSPECTIONS}

Quarterly visual site inspections will be completed at the 92-Acre Area for at least 30 years. Inspections will be conducted to verify that the UR warning signs are in place and readable and that the UR has been maintained. During the quarterly inspections, the cover will be inspected for cracks, animal burrows, or other evidence of subsidence or erosion, and the integrity of the berms will be verified. In addition, non-scheduled inspections will be conducted if precipitation occurs in excess of 1.0 inch in a 24-hour period at the rain gauge shown in Figure 2, which is located near the southeast corner of the Area 5 RWMS. These inspections will be conducted to verify the continued integrity of the cover and document any ponding or erosion.

The subsidence survey monuments will be land surveyed on an annual basis to determine if the cover has subsided. In addition, an annual assessment will be conducted by an ecological specialist or biologist to evaluate the success of the establishment of vegetation on the cover and make recommendations for maintenance of the vegetation.

The results of inspections, subsidence surveys, and vegetation surveys will be documented in the annual combined post-closure report for closed RCRA CAUs and submitted to NDEP. The post-closure report will include a discussion of observations made during the inspections, record the subsidence survey results, summarize the results of the vegetation survey, and provide a record of repair and maintenance activities. In addition, copies of the completed inspection checklists, field notes recorded during the inspections, and photographs taken during the inspections to document site conditions will be included in the post-closure report.

\subsection{MONITORING}

Post-closure monitoring will consist of continuing the current monitoring activities identified in Section 2.1, enhanced with a progressive approach for vadose zone monitoring. The current monitoring network is shown in Figure 2 and summarized in Table 1. Of the current monitoring activities identified in Table 1, soil gas monitoring and biota monitoring are not proposed to be continued during the post-closure period. Table 5 summarizes the post-closure inspection and monitoring activities that will be conducted, the compliance criteria established for each activity, and the actions required if the compliance criteria are exceeded. 


\section{Table 5. Post-Closure Requirements and Complance Criteria FOR THE 92-ACRE AREA}

\begin{tabular}{|c|c|c|}
\hline ACtivity & REQUIREMENT & COMPLIANCE CRITERIA AND ACTIONS \\
\hline $\begin{array}{l}\text { Visual } \\
\text { Inspections }\end{array}$ & $\begin{array}{l}\text { - Quarterly visual site inspections for cracks, } \\
\text { animal burrows, subsidence, erosion, and } \\
\text { FFACO UR compliance } \\
\text { - Additional inspections for ponding and } \\
\text { erosion after precipitation events in excess } \\
\text { of } 1.0 \text { inch in a 24-hour period }\end{array}$ & $\begin{array}{l}\text { Cracks or settling imperfections greater than } 15 \mathrm{~cm} \text { deep that } \\
\text { extend } 1.0 \mathrm{~m} \text { or more on the cover (through animal burrows, } \\
\text { erosion, or subsidence) will be reported to NDEP within } \\
14 \text { days and repaired within } 60 \text { days of discovery. Damaged or } \\
\text { missing UR warning signs will be repaired or replaced within } \\
60 \text { days of discovery. Evidence of human intrusion into the } \\
\text { cover will be reported to NDEP immediately upon discovery. }\end{array}$ \\
\hline $\begin{array}{l}\text { Subsidence } \\
\text { Surveys }\end{array}$ & $\begin{array}{l}\text { Annual land surveys of subsidence survey } \\
\text { monuments }\end{array}$ & $\begin{array}{l}\text { Significant subsidence will be reported to NDEP within } 14 \text { days } \\
\text { and repaired within } 60 \text { days of discovery. }\end{array}$ \\
\hline $\begin{array}{l}\text { Vegetation } \\
\text { Surveys }\end{array}$ & $\begin{array}{l}\text { Annual survey by an ecological specialist or } \\
\text { biologist }\end{array}$ & $\begin{array}{l}\text { Recommendations made by ecological specialist or biologist } \\
\text { will be implemented. }\end{array}$ \\
\hline $\begin{array}{l}\text { Direct } \\
\text { Radiation } \\
\text { Monitoring }\end{array}$ & Quarterly measurements from TLDs & $\begin{array}{l}\text { TLD exposure rate measurements greater than } 3 \text { times } \\
\text { background will be reported to NDEP within } 14 \text { days of } \\
\text { discovery. }\end{array}$ \\
\hline $\begin{array}{l}\text { Air } \\
\text { Monitoring }\end{array}$ & $\begin{array}{l}\text { Atmospheric moisture samples analyzed for } \\
\text { tritium every two weeks and air samples } \\
\text { submitted for laboratory analysis of } \\
\text { gamma-emitting and isotopic radionuclides } \\
\text { monthly }\end{array}$ & $\begin{array}{l}\text { Radionuclide concentrations in air that exceed the limits } \\
\text { identified in Table } 6 \text { will be reported to NDEP within } 14 \text { days } \\
\text { of discovery. }\end{array}$ \\
\hline $\begin{array}{l}\text { Radon Flux } \\
\text { Monitoring }\end{array}$ & Annual measurements of radon flux & $\begin{array}{l}\text { Radon fluxes that exceed the regulatory limit of } 20 \mathrm{pCi} / \mathrm{m}^{2} \mathrm{~s} \text { will } \\
\text { be reported to NDEP within } 14 \text { days of discovery. }\end{array}$ \\
\hline $\begin{array}{l}\text { Groundwater } \\
\text { Monitoring }\end{array}$ & $\begin{array}{l}\text { Water levels in the three existing wells } \\
\text { measured quarterly and groundwater samples } \\
\text { analyzed for contamination indicators and } \\
\text { water chemistry parameters every } 6 \text { months }\end{array}$ & $\begin{array}{l}\text { Groundwater indicators of contamination that exceed the } \\
\text { limitations listed in Table } 7 \text { or water chemistry parameters that } \\
\text { exceed the National Primary Drinking Water Standards } \\
\text { (CFR, 2006a) will be reported to NDEP within } 14 \text { days of } \\
\text { discovery. }\end{array}$ \\
\hline $\begin{array}{l}\text { Meteorology } \\
\text { Monitoring }\end{array}$ & $\begin{array}{l}\text { Precipitation, air temperature, relative } \\
\text { humidity, wind speed and direction, and } \\
\text { barometric pressure recorded daily }\end{array}$ & None \\
\hline $\begin{array}{l}\text { Vadose Zone } \\
\text { Monitoring }\end{array}$ & $\begin{array}{l}\text { TDR probe and lysimeter data downloaded } \\
\text { quarterly }\end{array}$ & See Table 8. \\
\hline $\begin{array}{l}\text { Evaluation of } \\
\text { Monitoring } \\
\text { Program }\end{array}$ & $\begin{array}{l}\text { Monitoring program evaluated every } 5 \text { years to } \\
\text { determine whether the frequency and/or } \\
\text { approach should be modified }\end{array}$ & None \\
\hline
\end{tabular}

CFR: Code of Federal Regulations

cm: centimeter(s)

FFACO: Federal Facility Agreement and Consent Order

$\mathrm{m}$ : meter(s)

NDEP: Nevada Division of Environmental Protection

$\mathrm{pCi} / \mathrm{m}^{2} \mathrm{~s}$ : picocurie(s) per square meter per second

TDR: time-domain reflectometry

TLD: thermoluminescent dosimeter

UR: use restriction 
Table 6. Compliance Criteria for Air Monitoring

\begin{tabular}{|c|c|}
\hline PARAMETER & DCG \\
\hline \hline Tritium & $25,000 \mathrm{pCi} / \mathrm{m}^{3}$ \\
\hline Americium-241 & $0.005 \mathrm{pCi} / \mathrm{m}^{3}$ \\
\hline Plutonium-238 & $0.0075 \mathrm{pCi} / \mathrm{m}^{3}$ \\
\hline Plutonium-239/240 & $0.005 \mathrm{pCi} / \mathrm{m}^{3}$ \\
\hline
\end{tabular}

DCG: Derived Concentration Guide (scaled to a 25-millirem per year inhaled dose to the public constraint) (U.S. Department of Energy, 1993)

$\mathrm{pCi} / \mathrm{m}^{3}$ : picocurie(s) per cubic meter

\section{TABLE 7. Limitations For GroundWATER IndiCATOR PARAMETERS}

\begin{tabular}{|c|c|}
\hline PARAMETER & LIMITATIONS \\
\hline \hline $\mathrm{pH}$ & Between 7.6 and 9.2 \\
\hline Specific Conductance & $<0.440 \mathrm{mmhos} / \mathrm{cm}$ \\
\hline Total Organic Carbon & $<1 \mathrm{mg} / \mathrm{L}$ \\
\hline Total Organic Halides & $<50 \mu \mathrm{g} / \mathrm{L}$ \\
\hline Tritium & $<2,000 \mathrm{pCi} / \mathrm{L}$ \\
\hline
\end{tabular}

mmhos/cm: millimho(s) per centimeter $\quad \mu \mathrm{g} / \mathrm{L}: \operatorname{microgram}(\mathrm{s})$ per liter $\mathrm{mg} / \mathrm{L}:$ milligram(s) per liter $\quad \mathrm{pCi} / \mathrm{L}:$ picocurie(s) per liter

Because there is some uncertainty associated with the contents of the landfill units, this monitoring program is sufficient to identify migration of any potential contaminants within the landfill units.

According to 40 CFR 265, Subpart G, §265.117, "Post-Closure Care and Use of Property," post-closure monitoring will be conducted for at least 30 years (CFR, 2006d). Every 5 years, the monitoring program will be evaluated to determine whether the frequency and/or approach should be modified based on monitoring results, changes in climatic conditions, potential change in the direction of the aquifer flow, and offsite activities that could impact water quality. During these 5-year monitoring evaluations, NNSA/NSO may request that the frequency and/or complexity of monitoring be adjusted.

The proposed monitoring program is more conservative and more protective than required by 40 CFR 265 or precedence. According to 40 CFR 265, Subpart F, \$265.90, "Ground-Water Monitoring," all or part of the groundwater monitoring requirements in this subpart may be waived if it can be demonstrated that there is a low potential for migration of hazardous constituents via the uppermost aquifer to water supply wells or to surface water (CFR, 2006d). For CAU 110, Area 3 RWMS U-3ax/bl Disposal Unit, a historic RCRA disposal unit located in Area 3 of the NNSS with similar climatic and geologic conditions to the 92-Acre Area, such a waiver was requested and approved, and as such, groundwater monitoring is not required for CAU 110 (NNSA/NV, 2000). 
At the 92-Acre Area, the average annual potential evapotranspiration is many times the average precipitation rate. The site is far from surface waters, surface runoff and run-on is insignificant, and engineered berms provide protection from a 25-year flood. Plant evapotranspiration minimizes potential water transport through the cover, and the plant canopy and roots help control erosion of the surface by wind and rain.

The vadose zone below the waste cells has low water potentials, low conductivity rates, and ample water storage capacity. Therefore, the potential for downward transmission of water is extremely low. Below this zone, water potential measurements indicate a static zone where essentially no vertical liquid flow is currently occurring. Conservative modeling estimates suggest it would take more than 50,000 years for water to move from beneath the static region to the groundwater, which is over $200 \mathrm{~m}$ below ground surface.

If water were to carry contaminants to the groundwater, water levels indicate that the gradient is nearly flat, and calculated groundwater flow velocities have generally been less than $0.15 \mathrm{~m}$ per year. Effectively, there is no groundwater pathway, and the potential for groundwater contamination from waste disposal activities at the Area 5 RWMS is negligible.

A groundwater monitoring waiver is not being requested for the 92-Acre Area, even though it has been demonstrated by extensive site characterization, environmental monitoring, and modeling over the past several decades that the potential for groundwater contamination at the Area 5 RWMS is negligible. Rather, a continuation of current groundwater monitoring with the existing wells is proposed, coupled with aggressive monitoring of the vadose zone to provide early indication of contaminant transport towards groundwater.

The current monitored groundwater parameters are sufficient indicators of contamination in the groundwater. The Revised Area 5 Radioactive Waste Management Site Outline of a Comprehensive Groundwater Monitoring Program details an appropriate groundwater monitoring program for the Area 5 RWMS. The program ensures the earliest possible detection of contaminants based on a thorough analysis of site characteristics, current and future waste streams, past and present monitoring data, and 40 CFR 265 requirements. The parameters are good indicators of the waste constituents at the Area 5 RWMS, and the ILs defined are protective of the environment (BN, 1998). This program was agreed upon by NNSA/NSO and NDEP and has been followed since 1998 .

There is no requirement for vadose zone monitoring in 40 CFR 265; however, this will provide additional assurance that any future contaminant migration through the vadose zone towards the groundwater will be detected. At any time in the future, if there is any indication of movement of contamination through the vadose zone or potential groundwater contamination, the monitored groundwater parameters may be expanded based upon discussions between NNSA/NSO and NDEP at that time.

The only known potential conduit to the groundwater is groundwater monitoring wells themselves. Therefore, rather than installing additional wells at this time, which could potentially become conduits for contamination, and would likely become unserviceable long before any contaminants have time to reach the groundwater, a rigorous progressive, or graduated, monitoring approach will be implemented for vadose zone monitoring (Table 8). This approach does not preclude the installation of additional groundwater monitoring wells or the expansion of the monitored groundwater parameters in the future, as needed. 
Table 8. Progressive Approach for Vadose Zone Monitoring for the 92-Acre AreA

\begin{tabular}{|c|c|c|c|}
\hline $\begin{array}{c}\text { Progressive } \\
\text { Monitoring SteP }\end{array}$ & DESCRIPTION & $\begin{array}{l}\text { BASELINE/ACCEPTABLE } \\
\text { CONDITION }\end{array}$ & $\begin{array}{c}\text { TRIGger CONDITION FOR } \\
\text { ProgrESSING TO THE NEXT STEP }\end{array}$ \\
\hline Step 1: Base Monitoring & $\begin{array}{l}\text { Current TDR and lysimeter monitoring } \\
\text { network, as described in Section 2.1.6 and } \\
\text { Section 2.2.1.6 (See Figure 36) }\end{array}$ & $\begin{array}{l}\text { No indication of contaminant } \\
\text { migration beneath the waste } \\
\text { zone }\end{array}$ & $\begin{array}{l}\text { Volumetric moisture content greater than } \\
30 \text { percent* for } 2 \text { consecutive years at the deepest } \\
\text { TDR probe location }(1.2 \mathrm{~m} \text { beneath the floor of } \\
\text { Pit 5) }\end{array}$ \\
\hline $\begin{array}{l}\text { Step 2: Expanded Soil } \\
\text { Moisture Monitoring } \\
\text { Beneath the Waste Zone }\end{array}$ & $\begin{array}{l}\text { Drill borehole for neutron probe monitoring or } \\
\text { install TDR probes adjacent to waste cells to a } \\
\text { depth of } 3 \text { m beneath the waste zone } \\
\text { (See Figure } 36 \text { ) }\end{array}$ & $\begin{array}{l}\text { No indication of contaminant } \\
\text { migration beneath the waste } \\
\text { zone }\end{array}$ & $\begin{array}{l}\text { Volumetric moisture content greater than } \\
30 \text { percent* for } 2 \text { consecutive years at the deepest } \\
\text { probe location ( } 3 \mathrm{~m} \text { beneath the waste zone) }\end{array}$ \\
\hline $\begin{array}{l}\text { Step 3: Soil Sampling } \\
\text { for Contaminants } \\
\text { Beneath the Waste Zone }\end{array}$ & $\begin{array}{l}\text { Collect soil samples at } 3 \mathrm{~m} \text { below the waste } \\
\text { zone (e.g., geoprobe, core drill) near the } \\
\text { location(s) exceeding the trigger condition in } \\
\text { Step } 2 \text { and analyze for RCRA toxicity } \\
\text { characteristic contaminants (CFR, 2006c) and } \\
\text { radionuclides, or other contaminants, as } \\
\text { agreed upon by NNSA/NSO and NDEP } \\
\text { (See Figure 36) }\end{array}$ & $\begin{array}{l}\text { No contaminants detected } \\
\text { above TCLP (CFR, 2006c) or } \\
\text { radionuclide action levels in } \\
\text { the soil beneath the waste zone }\end{array}$ & $\begin{array}{l}\text { Contaminants detected in soil sample above } \\
\text { TCLP (CFR, 2006c) or radionuclide action levels } \\
\text { (after background comparison) }\end{array}$ \\
\hline $\begin{array}{l}\text { Step 4: Deep Vadose } \\
\text { Zone Monitoring }\end{array}$ & $\begin{array}{l}\text { Install heat dissipation probes at } 10-\mathrm{m} \\
\text { increments to } 100 \mathrm{~m} \text { below ground surface at } \\
\text { one location outside the } 92 \text {-Acre Area to } \\
\text { measure the water potential gradient } \\
\text { (See Figure 36) }\end{array}$ & $\begin{array}{l}\text { No downward movement of } \\
\text { water in the deep vadose zone }\end{array}$ & $\begin{array}{l}\text { Trend of downward movement of water in the } \\
\text { deep vadose zone for } 2 \text { consecutive years }\end{array}$ \\
\hline $\begin{array}{l}\text { Step 5: Expanded } \\
\text { Groundwater Monitoring }\end{array}$ & $\begin{array}{l}\text { Install additional groundwater monitoring } \\
\text { well(s) at location(s) agreed upon by } \\
\text { NNSA/NSO and NDEP }\end{array}$ & $\begin{array}{l}\text { No contaminants or indicators } \\
\text { of contamination detected in } \\
\text { the groundwater }\end{array}$ & $\begin{array}{l}\text { Groundwater is the point of compliance. } \\
\text { Indicators of contamination that exceed the } \\
\text { limitations listed in Table } 7 \text { will be reported to } \\
\text { NDEP within } 14 \text { days of discovery. }\end{array}$ \\
\hline
\end{tabular}

*A volumetric moisture content of 30 percent is a conservative field capacity value for the soil in this area. m: meter(s)

NNSA/NSO: U.S. Department of Energy, National Nuclear Security Administration Nevada Site Office

NDEP: Nevada Division of Environmental Protection

RCRA: Resource Conservation and Recovery Act

TCLP: Toxicity Characterization Leaching Procedure

TDR: time-domain reflectometry 
Date: November 2010

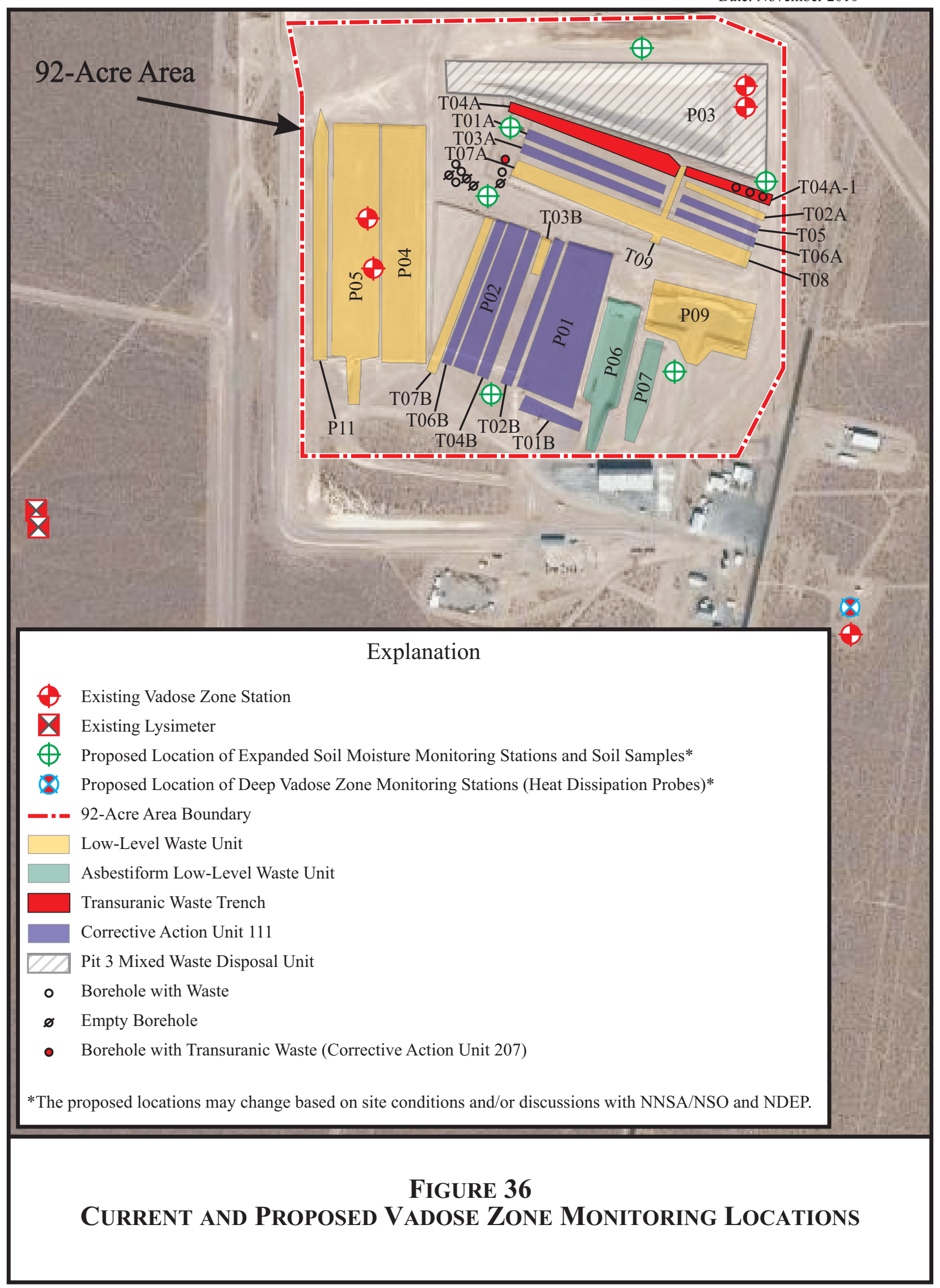


Given the geologic and climatic conditions of the area, this progressive monitoring approach begins with simple, near-surface monitoring that is currently conducted at the 92-Acre Area and progresses to deeper, more complex monitoring only upon indication of potential contaminant migration or drastic changes in climatic conditions. Using this approach, additional groundwater wells would be installed upon indication of potential contaminant migration through the vadose zone. Table 8 provides the specific details of the progressive monitoring approach for vadose zone monitoring.

If at any time, a trigger condition for vadose zone monitoring, as identified in Table 8, is exceeded, vadose zone monitoring will progress to the next, more rigorous, monitoring step. Exceeding a trigger condition does not imply an out-of-compliance condition; rather, it indicates that expanded monitoring is required to ensure the continued protection of human health and the environment. This progressive monitoring approach provides the greatest assurance that potential contaminant transport will be identified early without the unnecessary introduction of additional direct conduits to the groundwater.

The most current and acceptable technology for each progressive monitoring step is identified in Table 8; however, it is expected that as technology progresses over time, improved technology may be available at the time of implementation and will be used in lieu of those described in Table 8 .

The proposed locations of expanded soil moisture monitoring stations, soil samples, and deep vadose zone monitoring stations, as shown in Figure 36, were chosen based on the locations of the landfill units, the types of waste present in each unit, and the locations of existing vadose zone stations. The proposed locations may change based on site conditions and/or discussions between NNSA/NSO and NDEP if these monitoring activities are required in the future.

Results of monitoring will continue to be documented annually in the Nevada Test Site Waste Management Monitoring Report Area 3 and Area 5 Radioactive Waste Management Sites and in the Nevada Test Site Data Report: Groundwater Monitoring Program Area 5 Radioactive Waste Management Site. A copy of these reports will be included as an appendix to the annual combined post-closure report for closed RCRA CAUs.

\subsection{MAINTENANCE AND REPAIR}

Any identified maintenance or repair requirements will be reported to NDEP and completed within 60 calendar days of discovery. Repair work shall preserve the original "as-built" cover design. If the cover repair requires the modification of the cover design, NNSA/NSO shall present a formal design modification request to NDEP prior to making the design modification. All repair and maintenance activities will be documented in writing at the time of the repair and included in the annual combined post-closure report for closed RCRA CAUs. 
92-Acre Area and CAU $111 \mathrm{CADD} / \mathrm{CAP}$

Section: Post-Closure Plan

Revision: 1

Date: November 2010

\section{THIS PAGE INTENTIONALLY LEFT BLANK}


Bechtel Nevada, 1998. Revised Area 5 Radioactive Waste Management Site Outline of a Comprehensive Groundwater Monitoring Program. Las Vegas, NV.

Bechtel Nevada, 2006. Addendum 2 to the Performance Assessment of the Area 5 RWMS at the NTS, Nye County, Nevada Update of the Performance Assessment Methods and Results. DOE/NV/11718--176ADD2. Las Vegas, NV.

BN, see Bechtel Nevada.

CFR, see Code of Federal Regulations.

Code of Federal Regulations, 2006a. Title 40, Part 141, "National Primary Drinking Water Regulations." Washington, D.C.

Code of Federal Regulations, 2006b. Title 40, Part 191, "Environmental Radiation Protection Standards for Management and Disposal of Spent Nuclear Fuel, High-Level and Transuranic Radioactive Wastes.” Washington, D.C.

Code of Federal Regulations, 2006c. Title 40, Part 261, Subpart C, §261.24, “Toxicity Characteristic." Washington, D.C.

Code of Federal Regulations, 2006d. Title 40, Part 265, "Interim Status Standards for Owners and Operators of Hazardous Waste Treatment, Storage, and Disposal Facilities." Washington, D.C.

DOE, see U.S. Department of Energy.

Dwyer, S. F., J. C. Stormont, and C. E. Anderson, 1999. Mixed Waste Landfill Design Report. SAND99-2514. Sandia National Laboratories. Sandia, NM.

EPA, see U.S. Environmental Protection Agency.

Federal Facility Agreement and Consent Order, 1996 (as amended February 2008). Agreed to by the State of Nevada; the U.S. Department of Energy, Environmental Management; the U.S. Department of Defense; and the U.S. Department of Energy, Legacy Management.

Federal Facility Agreement and Consent Order, 2003. FFACO Use Restriction Posting Guidance for NNSA/NSO and Associated Contractors.

FFACO, see Federal Facility Agreement and Consent Order.

Madalinski, K. L., D. N. Gratton, and R. J. Weisman, 2003. Evapotranspiration covers: An innovative approach to remediate and close contaminated sites. Remediation Journal, Vol. 14, Iss. 1, pp. 55-67.

NAC, see Nevada Administrative Code.

National Security Technologies, LLC, 2008. Nevada Test Site 2007 Waste Management Monitoring Report Area 3 and Area 5 Radioactive Waste Management Sites. DOE/NV/25946--490. Las Vegas, NV.

National Security Technologies, LLC, 2009. Nevada Test Site 2008 Data Report: Groundwater Monitoring Program Area 5 Radioactive Waste Management Site. DOE/NV/25946--619. Las Vegas, NV.

NDEP, see Nevada Division of Environmental Protection. 
Nevada Administrative Code, 2006. NAC 444.8632, “Compliance with Federal Regulations Adopted by Reference." Carson City, NV.

Nevada Division of Environmental Protection, 2005. Permit for a Hazardous Waste Management Facility, Permit Number NEV HW0021. Carson City, NV.

NNSA/NV, see U.S. Department of Energy, National Nuclear Security Administration Nevada Operations Office

NSTec, see National Security Technologies, LLC.

Reynolds Electrical and Engineering Company, Inc, 1994. Alternative Evaluation Study, Ideal Cells for Arid Areas and Covers for the U-3ax/bl Disposal Unit. DOE/NV/11432--191. Las Vegas, NV.

Shott, G. J., L. E. Barker, S. E. Rawlinson, M. J. Sully, and B. A. Moore, 1998. Performance Assessment of the Area 5 Radioactive Waste Management Site at the Nevada Test Site, Nye County, Nevada, Revision 2.1. DOE/NV/11718--176. Las Vegas, NV.

Shott, G. J. and V. Yucel, 2009. Optimization of the Area 5 Radioactive Waste Management Site Closure Cover. DOE/NV/25946--695. Las Vegas, NV.

U.S. Department of Energy, 1993. DOE O 5400.5, "Radiation Protection of the Public and the Environment." Washington, D.C.

U.S. Department of Energy, 1997. Resource Conservation and Recovery Act Corrective Measures Study: Area 6 Decontamination Pond Facility, Corrective Action Unit No. 92. DOE/NV-493. Las Vegas, NV.

U.S. Department of Energy, 1999. DOE O 435.1, "Radioactive Waste Management." Washington, D.C.

U.S. Department of Energy, 2000. Alternative Landfill Cover. DOE/EM-0558. Innovative Technology Summary Report. Sandia, NM.

U.S. Department of Energy, National Nuclear Security Administration Nevada Operations Office, 1999. Characterization Report for Corrective Action Unit 110: Area 3 U-3ax/bl Disposal Unit, Nevada Test Site, Nevada. DOE/NV--580. Las Vegas, NV.

U.S. Department of Energy, National Nuclear Security Administration Nevada Operations Office, 2000. Closure Plan for Corrective Action Unit 110: Area 3 RWMS U-3ax/bl Disposal Unit, Nevada Test Site, Nevada. DOE/NV--647. Las Vegas, NV.

U.S. Environmental Protection Agency, 1991. Guidance on RCRA Corrective Action Decision Documents. EPA/540/G-91/011. Washington, D.C.

U.S. Environmental Protection Agency, 1994. Final RCRA Corrective Action Plan. EPA/520-R-94-004. Washington, D.C. 
92-Acre Area and CAU 111 CADD/CAP Section: Appendix A

Revision: 1

Date: November 2010

\section{Appendix A}

\section{DATA QUALITY OBJECTIVES}


92-Acre Area and CAU $111 \mathrm{CADD} / \mathrm{CAP}$ Section: Appendix A

Revision: 1

Date: November 2010

THIS PAGE INTENTIONALLY LEFT BLANK 


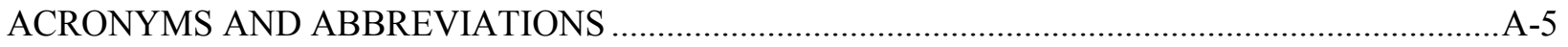

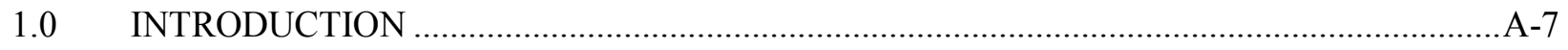

1.1 DOCUMENTS SUPPORTING SITE CHARACTERIZATION .................................................. A-8

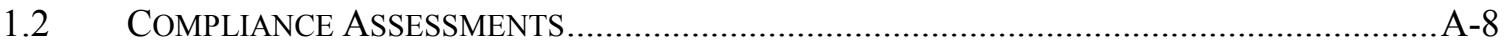

1.3 MANAGEMENT OF UNCERTAINTY AND WASTE INVENTORIES ...................................A-12

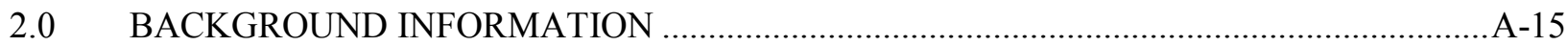

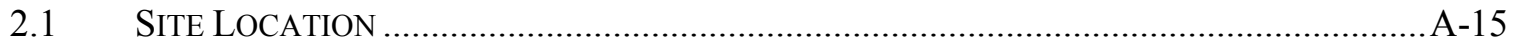

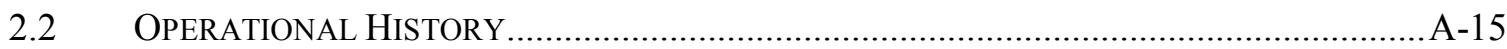

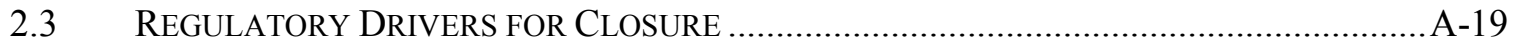

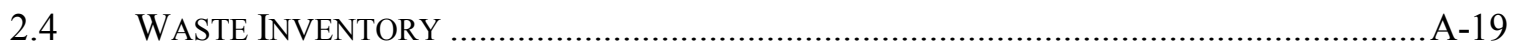

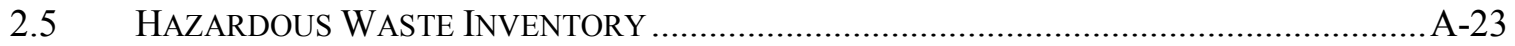

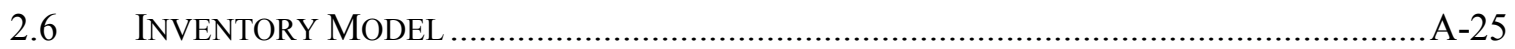

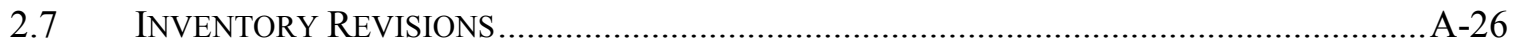

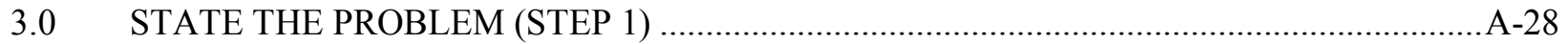

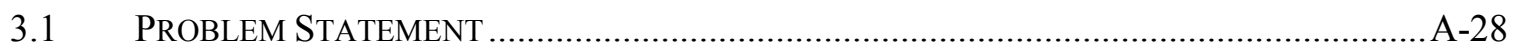

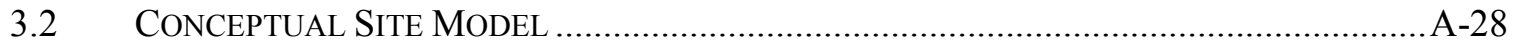

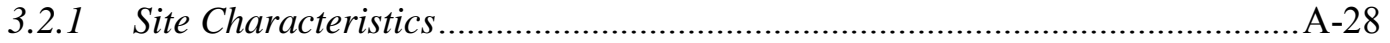

3.2.2 Facility Assessments Conceptual Model .....................................................

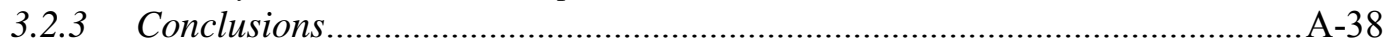

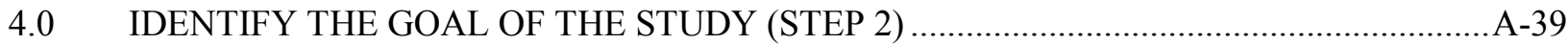

5.0 IDENTIFY INFORMATION INPUTS (STEP 3) …............................................................40

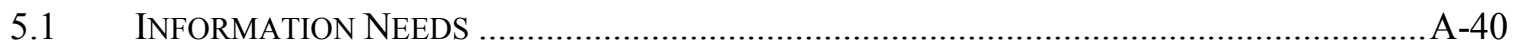

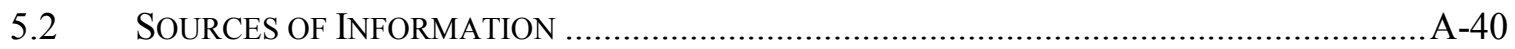

6.0 DEFINE THE BOUNDARIES OF THE STUDY (STEP 4) .................................................42

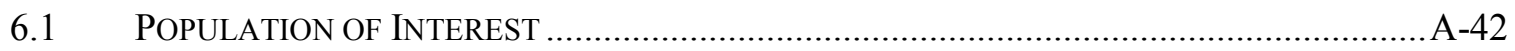

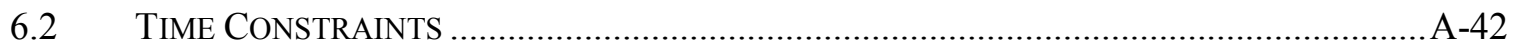

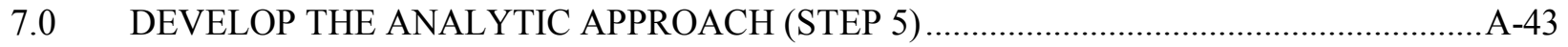

7.1 DECISION RULES .................................................................................. A-43

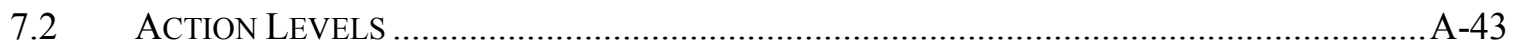

7.3 MEASUREMENT AND ANALYSIS SENSITIVITY ............................................................

8.0 SPECIFY PERFORMANCE OR ACCEPTANCE CRITERIA (STEP 6) .................................4

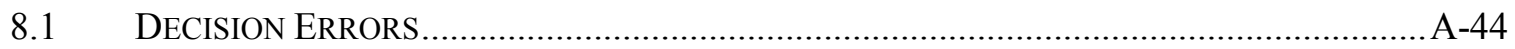

9.0 DEVELOP THE PLAN FOR OBTAINING DATA (STEP 7) …..........................................45

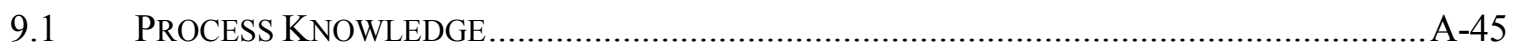

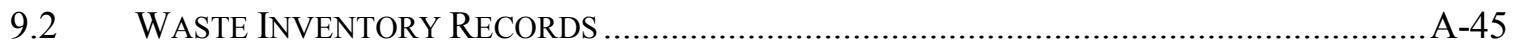

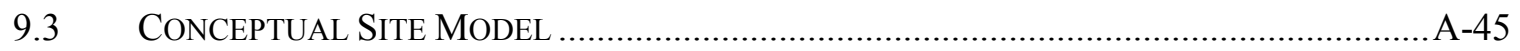

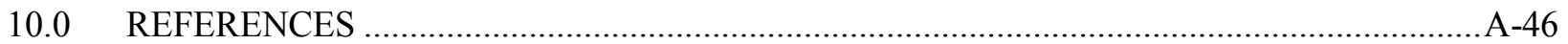




\section{FIGURES}

Figure A-1. SteEl Drums Over-PaCked into Larger Steel Containers at the Area 5

Figure A-2. Area 5 Radioactive Waste Management Site Location Map A-16

Figure A-3. 92-ACRE AREA Disposal Units A-17

Figure A-4. PA Model of Unsaturated Flow in the Vadose Zone A-34

\section{TABLES}

TABle A-1. Summary of PA Results And Compliance Evaluation ............................. A-10

TABle A-2. Summary of CA Results AND ComplianCE Evaluation.............................. A-10

TABle A-3. SuMmary OF PA RESUlts AND COMPLIANCE EVALUATION UNDER THE 1985 VERSION OF 40 CFR 191 FOR THE TRU WASTE IN THE GCD BOREHOLES .... A-11

TABLE A-4. SUMmARY OF SA RESUlTS AND COMPARISON WITH THE STANDARDS CONTAINED IN THE 1997 VERSION OF 40 CFR 191 FOR THE TRU WASTE IN TRENCH T04A. A-12

TABle A-5. SEnsitivity of the Transient Visitor Air PathWAy TEDE at 1,000 YEARS. A-13

TABle A-6. Sensitivity of the Resident Farmer All Pathways TEDE at 1,000 YEARS. A-13

Table A-7. Sensitivity of the RAdON-222 Flux Density at 1,000 YeArs. A-14

TABLE A-8. 92-ACRE AREA WASTE UNIT STATUS A-20

TABle A-9. CAU 111 Cell Designations A-24

TABle A-10. CAU 111 Hazardous Waste Constituents A-25 


\section{ACRONYMS AND ABBREVIATIONS}

\begin{tabular}{|c|c|}
\hline ALARA & as low as reasonably achievable \\
\hline ANSI & American National Standards Institute \\
\hline $\mathrm{BN}$ & Bechtel Nevada \\
\hline $\mathrm{Bq} \mathrm{L}^{-1}$ & Becquerel(s) per liter \\
\hline $\mathrm{Bq} \mathrm{m}^{-2} \mathrm{~s}^{-1}$ & Becquerel(s) per square meter per second \\
\hline $\mathrm{CA}$ & composite analysis \\
\hline $\mathrm{CADD} / \mathrm{CAP}$ & Corrective Action Decision Document/Corrective Action Plan \\
\hline CAU & Corrective Action Unit \\
\hline CFR & Code of Federal Regulations \\
\hline $\mathrm{CR}$ & containment requirement \\
\hline CSM & conceptual site model \\
\hline DAS & Disposal Authorization Statement \\
\hline DASH & Deep Arid System Hydrodynamic \\
\hline DCG & Derived Concentration Guide \\
\hline DOE & U.S. Department of Energy \\
\hline DQO & data quality objective \\
\hline EPA & U.S. Environmental Protection Agency \\
\hline FEHM & finite element heat and mass transfer \\
\hline FFACO & Federal Facility Agreement and Consent Order \\
\hline $\mathrm{ft}$ & foot (feet) \\
\hline $\mathrm{ft}^{3}$ & cubic foot (feet) \\
\hline FY & fiscal year \\
\hline GCD & Greater Confinement Disposal \\
\hline GCDT & Greater Confinement Disposal Test \\
\hline ICMP & integrated closure and monitoring plan \\
\hline in. & inch(es) \\
\hline IPR & individual protection requirement \\
\hline LLW & low-level waste \\
\hline LWIS & Low-Level Waste Information System \\
\hline M & Manual \\
\hline MFP & mixed fission product \\
\hline $\mathrm{mi}$ & mile(s) \\
\hline $\mathrm{mm} / \mathrm{yr}$ & millimeter(s) per year \\
\hline
\end{tabular}




\section{ACRONYMS AND ABBREVIATIONS (continued)}

\begin{tabular}{|c|c|}
\hline MOP & member of the public \\
\hline $\mathrm{mph}$ & mile(s) per hour \\
\hline $\mathrm{mR} / \mathrm{day}$ & milliroentgen(s) per day \\
\hline $\mathrm{mrem} / \mathrm{yr}$ & millirem(s) per year \\
\hline $\mathrm{mSv} / \mathrm{yr}$ & milliSievert(s) per year \\
\hline MTRU & mixed transuranic \\
\hline MW & mixed waste \\
\hline MWDU & Mixed Waste Disposal Unit \\
\hline NAC & Nevada Administrative Code \\
\hline NDEP & Nevada Division of Environmental Protection \\
\hline NCRP & National Council on Radiation Protection and Measurements \\
\hline NFB & no-flux boundary \\
\hline NNSA/NSO & $\begin{array}{l}\text { U.S. Department of Energy, National Nuclear Security Administration } \\
\text { Nevada Site Office }\end{array}$ \\
\hline NNSS & Nevada National Security Site \\
\hline NWAR & nuclear weapons accident residue \\
\hline $\mathrm{O}$ & Order \\
\hline PA & performance assessment \\
\hline PET & potential evapotranspiration \\
\hline pdf & probability density function \\
\hline QA/QC & quality assurance/quality control \\
\hline RCRA & Resource Conservation and Recovery Act \\
\hline REECo & Reynolds Electrical and Engineering Company, Inc. \\
\hline RWM & Radioactive Waste Management \\
\hline RWMS & Radioactive Waste Management Site \\
\hline SA & special analysis \\
\hline SLB & Shallow Land Burial \\
\hline TDR & time-domain reflectometry \\
\hline TEDE & total effective dose equivalent \\
\hline TRU & transuranic \\
\hline WMD & Waste Management Division \\
\hline
\end{tabular}




\subsection{INTRODUCTION}

The data quality objective (DQO) process is a seven-step systematic planning method based on the scientific method. The information presented in this document is based on characterization and monitoring data, historical documentation and records, modeling studies, evaluations, and process knowledge for the southeast quadrant of the Area 5 Radioactive Waste Management Site (RWMS), which is referred to as the "92-Acre Area." The DQOs were developed according to the U.S. Environmental Protection Agency (EPA) Guidance on Systematic Planning Using the Data Quality Objectives Process (EPA, 2006). The steps systematically build on the data acquired during preliminary assessment work and background research.

The Area 5 RWMS uses engineered shallow-land burial cells to dispose of packaged waste. The cells in the 92-Acre Area include 13 boreholes, 16 narrow trenches, and 9 broader pits. The waste disposal units have been established over a 45-year operation period. Three disposal units within the 92-Acre Area are currently active. All other pits and trenches have been operationally closed with temporary earthen covers of at least 8 feet $(\mathrm{ft})$ of native fill.

The 92-Acre Area includes Federal Facility Agreement and Consent Order (FFACO) Corrective Action Unit (CAU) 111, Area 5 WMD Retired Mixed Waste Pits, which consists of 11 trenches and pits that may have received both low-level waste (LLW) and mixed waste (MW) prior to the promulgation of the Resource Conservation and Recovery Act (RCRA). The 92-Acre Area also contains an active MW pit, two units which received asbestiform LLW, and six disposal units that are known or suspected to have received some transuranic (TRU) waste. The 92-Acre Area has been divided into six units based on physical location, waste types, and regulatory requirements:

- Pit 3 Mixed Waste Disposal Unit (MWDU)

- CAU 111, Area 5 WMD Retired Mixed Waste Pits

- CAU 207, Archived - Area 5 WMD Greater Confinement Disposal (GCD) Boreholes

- LLW disposal units

- Asbestiform LLW disposal units

- One TRU waste trench

Sufficient information is available about the physical, chemical, hydrological, plant, animal, and climate characteristics, as well as facility design, operation, and source materials to provide the input data necessary to evaluate closure options without the collection of additional data. Site characterization activities at the Area 5 RWMS began in the early 1990s. These activities have provided the necessary data to develop a conceptual site model (CSM) for the fate and transport of the waste inventory. The CSM, inventory, and release and transport parameters are presented in this document along with a discussion of their uncertainty. References that provide detailed information regarding characterization and modeling studies are provided. 


\subsection{Documents Supporting Site Characterization}

Documents related to characterization and site performance are listed below:

- Area 5 Site Characterization Project Report FY 1994 (Albright et al., 1994)

- Characterization Report: Operational Soil Covers for the Area 5 Radioactive Waste Management Sites at the Nevada Test Site (Bechtel Nevada [BN], 2005a)

- Hydrogeologic Characterization Data from the Area 5 Shallow Soil Trenches, Nevada Test Site, Nye County, Nevada (BN, 2005b)

- Site Characterization and Monitoring Data for the Area 5 Pilot Wells, Nevada Test Site, Nye County, Nevada (BN, 2005c)

- Addendum 2 to the Performance Assessment of the Area 5 RWMS at the NTS, Nye County, Nevada Update of the Performance Assessment Methods and Results (BN, 2006)

- Site Characterization Data from the Area 5 Science Boreholes, Nevada Test Site, Nye County, Nevada (Blout et al., 1995)

- Use of Long-Term Lysimeter Data in Support of Shallow Land Waste Disposal Cover Design (Desotell et al., 2006)

- Hydrogeologic Data for Existing Excavations at the Area 5 Radioactive Waste Management Site, Nevada Test Site, Nye County, Nevada (Reynolds Electrical and Engineering Company, Inc. [REECo], 1993a)

- Hydrogeologic Data for Science Trench Boreholes at the Area 5 Radioactive Waste Management Site, Nevada Test Site, Nye County, Nevada (REECo, 1993b)

- Flood Assessment at the Area 5 Radioactive Waste Management Site and the Proposed Hazardous Waste Storage Unit, Nevada Test Site, Nye County, Nevada (Schmeltzer et al., 1993)

- Performance Assessment of the Area 5 Radioactive Waste Management Site at the Nevada Test Site, Nye County, Nevada, Revision 2.1 (Shott et al., 1998)

- Soil-Water Flux in the Southern Great Basin, United States: Temporal and Spatial Variations over the Last 120,000 Years (Tyler et al., 1996)

- Vadose-zone Fluid and Solute Flux: Advection and Diffusion at the Area 5 Radioactive Waste Management Site (Wolfsberg and Stauffer, 2003)

\subsection{Compliance Assessments}

Four major assessments have been completed that demonstrate waste disposal operations at the Area 5 RWMS are in compliance with the U.S. Department of Energy (DOE) regulations and provide assurance that members of the public (MOPs) and the environment will be protected for 1,000 years after closure. These assessments include (1) the LLW performance assessment (PA), (2) the composite analysis (CA), (3) the PA for the TRU waste in the GCD boreholes, and (4) the special analysis (SA) for the TRU waste in trench T04A.

The PA, the CA, and the integrated closure and monitoring plan (ICMP) are the basis for the Disposal Authorization Statement (DAS) for the Area 5 RWMS. DOE issued the DAS for the operation of the Area 5 disposal facility in December 2000. 


\subsubsection{Performance Assessment for the Area 5 RWMS}

The Area 5 PA evaluates radiological impacts of LLW regulated by DOE Order (O) 435.1, "Radioactive Waste Management" (DOE, 1999a). Regulated LLW is limited to waste disposed from September 26, 1988, to the assumed closure date of September 30, 2028. Radiological hazards are assessed for a period of 1,000 years after site closure. The purpose of the PA is to determine if there is a reasonable expectation of compliance with the performance objectives in the DOE Radioactive Waste Management Manual, Chapter IV, Section P(1) (DOE, 1999a):

1) The dose to representative MOPs shall not exceed 0.25 milliSieverts per year $(\mathrm{mSv} / \mathrm{yr})$ total effective dose equivalent (TEDE) from all exposure pathways, excluding the dose from radon and its progeny in air.

2) The dose to representative MOPs via the air pathway shall not exceed $0.10 \mathrm{mSv} / \mathrm{yr}$ TEDE, excluding the dose from radon and its progeny.

3) The release of radon shall be less than an average flux of 0.74 Becquerel per square meter per second $\left(\mathrm{Bq} \mathrm{m}^{-2} \mathrm{~s}^{-1}\right)$ at the surface of the disposal facility. Alternatively, a limit of 0.0185 Becquerel per liter $\left(\mathrm{Bq} \mathrm{L}^{-1}\right)$ of air may be applied at the boundary of the facility.

Representative MOPs are interpreted to be members of the critical group engaged in typical activities expected for the region. The critical group includes those MOPs exposed to the highest radionuclide releases from the site. The MOP is assumed to be located 100 meters from the boundary of the total area of the disposal units. The average radon flux is interpreted to be the spatially averaged flux density calculated as the total site radon flux from the ground surface to the atmosphere, divided by the total area of the disposal units. In addition to providing a reasonable expectation that the performance objectives are not exceeded, the PA must also demonstrate that radionuclide releases are as low as reasonably achievable (ALARA).

Under DOE Manual (M) 435.1-1, "Radioactive Waste Management Manual" (DOE, 1999b), a PA must include an assessment of (1) impacts to groundwater and (2) impacts to a hypothetical person assumed to inadvertently intrude for a temporary period into the disposal facility. The results are used to set limits for radionuclides disposed in the near-surface. Groundwater impacts are assessed against the standards in the National Primary Drinking Water Regulations (Title 40 Code of Federal Regulations [CFR] Part 141). Intruder impacts are limited to ensure that the TEDE received by a chronically exposed intruder is less than $1.0 \mathrm{mSv}$. In the case of the Area 5 RWMS, the groundwater protection criteria are not used to set limits for radionuclides disposed in the near-surface. Site characterization data support a conclusion that a groundwater pathway is extremely unlikely (Shott et al., 1998). Table A-1 summarizes the PA results.

The PA was approved after a peer review with conditions by DOE in August 1996 (Shott et al., 1998). The DAS conditions were removed in May 2002 with acceptance of an addendum to the PA (BN, 2001a). Under the PA maintenance program, disposal site operations, waste inventories, research and development, and environmental monitoring results are reviewed annually, and the adequacy of the PA is evaluated. The 2004 annual review concluded that significant changes have occurred since preparation of the PA, and consequently, a second addendum was prepared and accepted without conditions in 2006 (BN, 2006). 
TABle A-1. Summary of PA Results ANd Compliance Evaluation

\begin{tabular}{|c|c|c|c|c|c|}
\hline \multirow{2}{*}{$\begin{array}{l}\text { PERformanCe } \\
\text { ObJECTIVE }\end{array}$} & \multirow[b]{2}{*}{ LIMIT } & \multicolumn{3}{|c|}{ LIMITING RESULT } & \multirow[b]{2}{*}{ CONCLUSION } \\
\hline & & SCENARIO & MEAN & $\begin{array}{c}95^{\mathrm{TH}} \\
\text { PERCENTILE } \\
\end{array}$ & \\
\hline Air Pathway & $0.1 \mathrm{mSv} / \mathrm{yr}$ & $\begin{array}{c}\text { Transient } \\
\text { Occupancy } \\
\end{array}$ & $4.1 \mathrm{E}-5 \mathrm{mSv} / \mathrm{yr}$ & 4.7E-4 mSv/yr & Complies \\
\hline All Pathways & $0.25 \mathrm{mSv} / \mathrm{yr}$ & Resident Farmer & $4.4 \mathrm{E}-2 \mathrm{mSv} / \mathrm{yr}$ & $3.9 \mathrm{E}-2 \mathrm{mSv} / \mathrm{yr}$ & Complies \\
\hline $\begin{array}{l}\text { Intruder Protection } \\
\text { (Acute Exposure) }\end{array}$ & $5 \mathrm{mSv}$ & \multicolumn{3}{|c|}{ Bounded by chronic exposure scenarios } & Complies \\
\hline $\begin{array}{l}\text { Intruder Protection } \\
\text { (Chronic Exposure) }\end{array}$ & $1 \mathrm{mSv}$ & $\begin{array}{l}\text { SLB Intruder } \\
\text { Agriculture }\end{array}$ & $0.12 \mathrm{mSv} *$ & $0.43 \mathrm{mSv}^{*}$ & Complies \\
\hline Radon Flux Density & $0.74 \mathrm{~Bq} \mathrm{~m}^{-2} \mathrm{~s}^{-1}$ & $\begin{array}{l}\text { All Disposal } \\
\text { Units }\end{array}$ & $0.044 \mathrm{~Bq} \mathrm{~m}^{-2} \mathrm{~s}^{-1}$ & $0.096 \mathrm{~Bq} \mathrm{~m}^{-2} \mathrm{~s}^{-1}$ & Complies \\
\hline $\begin{array}{l}\text { Groundwater } \\
\text { Protection }\end{array}$ & 40 CFR 141 & \multicolumn{3}{|c|}{ No groundwater pathway in 1,000 years } & Complies \\
\hline Releases ALARA & No Limit & \multicolumn{3}{|c|}{ Optimum cover thickness less than 13 feet } & ALARA \\
\hline $\begin{array}{l}\text { ALARA: as low as } \\
\text { Bq } \mathrm{m}^{-2} \mathrm{~s}^{-1}: \text { Becquere } \\
\text { CFR: Code of Feder }\end{array}$ & $\begin{array}{l}\text { asonably achievable } \\
\text { s) per square meter p } \\
\text { i Regulations }\end{array}$ & $\begin{array}{l}\mathrm{mSv} / \mathrm{y} \\
\text { SLB: } \\
\text { *Weig }\end{array}$ & $\begin{array}{l}\text { milliSievert(s) per year } \\
\text { allow Land Burial } \\
\text { d with probability of it }\end{array}$ & & \\
\hline
\end{tabular}

\subsubsection{Composite Analysis for the Area 5 RWMS}

The purpose of the CA is to determine if the continuing operation of the Area 5 RWMS poses an acceptable risk to the public considering the total waste inventory, regardless of disposal date, and all other interacting sources of radioactive material in the vicinity. Continuing operation of the facility is acceptable if the TEDE is less than 100 millirems per year (mrem/yr). If the TEDE exceeds $30 \mathrm{mrem} / \mathrm{yr}$, a cost-benefit options analysis must be performed to determine if cost-effective management options exist to reduce the dose further. If the TEDE is found to be less than $30 \mathrm{mrem} / \mathrm{yr}$, an analysis may be performed to determine if doses are ALARA.

The maximum CA dose to a MOP for the 1,000-year compliance period is $1 \mathrm{mrem} / \mathrm{yr}$ $(0.01 \mathrm{mSv} / \mathrm{yr})$ at 1,000 years after closure. The Area $5 \mathrm{CA}$ was accepted by DOE with conditions in 2001 (BN, 2001b), and an addendum was issued in 2001 (BN, 2001c). The CA evaluated the dose to a future MOP from all sources of radionuclides in the ground in Frenchman Flat and the releases from the facility, including all pre-1988 waste in the disposal cells.

Table A-2 summarizes the CA results for the Area 5 RWMS.

TABle A-2. Summary of CA Results AND Compliance Evaluation

\begin{tabular}{|c|c|c|c|c|c||}
\hline \multirow{2}{*}{$\begin{array}{c}\text { PERFORMANCE } \\
\text { ObJECTIVE }\end{array}$} & \multirow{2}{*}{ LIMIT } & SCENARIO & MEAN & $\begin{array}{c}\text { 95 }^{\text {TH }} \\
\text { PERCENTILE }\end{array}$ & CONCLUSION $^{\text {PIMING RESULT }}$ \\
\cline { 3 - 6 } & & Resident & $0.01 \mathrm{mSv}$ & $0.04 \mathrm{mSv}$ & Complies \\
\hline \hline All Pathways/All Sources & $0.3 \mathrm{mSv}$ & &
\end{tabular}

mSv: milliSievert(s) 


\subsubsection{Performance Analysis for the TRU Waste in the GCD Boreholes}

The TRU waste in GCD boreholes 1 through 4 was evaluated to demonstrate compliance with the requirements of 40 CFR 191, "Environmental Radiation Protection Standards for Management and Disposal of Spent Nuclear Fuel, High-Level, and Transuranic Radioactive Wastes." Relevant standards for TRU waste disposal are found in 40 CFR 191 Subpart B, "Environmental Standards for Disposal," and Subpart C, "Environmental Standards for Groundwater Protection." Subpart B standards include containment requirements (CRs), assurance requirements, and individual protection requirements (IPRs). The CRs are probabilistic limits for the normalized cumulative radionuclide release to the accessible environment for 10,000 years. The cumulative release is normalized to release limits scaled to the total TRU inventory disposed. The CRs limit the probability of exceeding the release limit to 1 chance in 10, and the probability of exceeding 10 times the release limit to 1 chance in 1,000. The assurance requirements specify institutional controls and disposal system features to increase confidence in the long-term compliance with the CRs. The required controls and features are active and passive institutional controls, monitoring, natural and engineered barriers, lack of attractive natural resources, and ability to retrieve wastes for a reasonable time period. The IPRs limit the committed effective dose to a MOP through all pathways for 10,000 years to $0.15 \mathrm{mSv} / \mathrm{yr}$. Subpart C requires that sources of underground drinking water in the accessible environment comply with the limits in 40 CFR 141 for a period of 10,000 years.

Sandia National Laboratories prepared a PA for the TRU GCD boreholes in 2001 (Cochran et al., 2001). In 2002, DOE determined that the PA met all requirements with the exception of the 40 CFR 191.14 assurance requirements for institutional controls; a monitoring program; markers, records, and other passive institutional controls; an engineered barrier system; information to support the claim that there are no economically useful minerals in the area; and removal of waste. The U.S. Department of Energy, National Nuclear Security Administration Nevada Site Office (NNSA/NSO) committed to resolve these issues during the closure planning process for the Area 5 RWMS (Colarusso et al., 2003). The TRU Federal Review Group would review closure and post-closure documents to determine compliance with the 1993 version of 40 CFR 191 (Fiore and Berube, 2002). A new assurance requirements document is being prepared. Table A-3 summarizes the PA results for the TRU waste in the GCD boreholes.

\section{TABle A-3. Summary of PA Results ANd Compliance Evaluation under the 1985 VERSION OF 40 CFR 191 FOR THE TRU WASTE IN THE GCD BOREHOLES}

\begin{tabular}{|c|c|c|c|c|c|}
\hline \multirow{2}{*}{$\begin{array}{l}\text { PERFORMANCE } \\
\text { OBJECTIVE }\end{array}$} & \multirow{2}{*}{ LIMIT } & \multicolumn{3}{|c|}{ LIMITING RESULT } & \multirow{2}{*}{ CONCLUSION } \\
\hline & & SCENARIO & MEAN & MAXIMUM & \\
\hline Containment Requirements & $\mathrm{P}(\mathrm{R}>1)<0.1$ & \multicolumn{3}{|c|}{$\mathrm{P}(\mathrm{R}>1)<0.0002$} & Complies \\
\hline Containment Requirements & $\mathrm{P}(\mathrm{R}>10)<0.001$ & \multicolumn{3}{|c|}{$\mathrm{P}(\mathrm{R}>10)<0.0002$} & Complies \\
\hline $\begin{array}{c}\text { Individual Protection } \\
\text { Requirements }\end{array}$ & $\begin{array}{c}0.25 \mathrm{mSv} \\
\text { Whole Body }\end{array}$ & $\begin{array}{l}\text { Resident } \\
\text { Farmer }\end{array}$ & 4.7E-5 $\mathrm{mSv}$ & $1.6 \mathrm{E}-3 \mathrm{mSv}$ & Complies \\
\hline $\begin{array}{l}\text { Individual Protection } \\
\text { Requirements }\end{array}$ & $\begin{array}{l}0.75 \mathrm{mSv} \\
\text { Any Organ }\end{array}$ & $\begin{array}{l}\text { Resident } \\
\text { Farmer }\end{array}$ & $\begin{array}{l}1.2 \mathrm{E}-3 \mathrm{mSv} \\
\text { Bone }\end{array}$ & $\begin{array}{l}4.5 \mathrm{E}-2 \mathrm{mSv} \\
\text { Bone }\end{array}$ & Complies \\
\hline $\begin{array}{c}\text { Groundwater Protection } \\
\text { Standard }\end{array}$ & 40 CFR 141 & \multicolumn{3}{|c|}{$\begin{array}{l}\text { Not applicable under } 1985 \text { version of } \\
40 \text { CFR } 191\end{array}$} & Complies \\
\hline
\end{tabular}

$\mathrm{P}(\cdot)$ : Probability of an event

R: Normalized cumulative release as defined in 40 CFR 191.27 mSv: milliSievert(s) 


\subsubsection{Special Analysis for the TRU Waste in Trench T04A}

In 1986, 102 55-gallon drums of TRU waste from Rocky Flats were inadvertently buried in T04A. The T04A TRU inventory was included in the 2001 CA; however, in order to provide further assurance that this small quantity of TRU in T04A will not pose a risk to future members of public, a 40 CFR 191 evaluation is considered relevant.

The SA was performed in 2007 to determine the likelihood that T04A meets the requirements of 40 CFR 191 (Shott et al., 2008). The SA concludes that there is a reasonable expectation that all 40 CFR 191 disposal requirements for a period of 10,000 years under climate change are met. Table A-4 summarizes the SA results for the TRU waste T04A.

\section{TABLE A-4. SUMMARY OF SA RESUlTS AND COMPARISON WITH THE STANDARDS CONTAINED IN THE 1997 VERSION OF 40 CFR 191 FOR THE TRU WASTE IN TRENCH T04A}

\begin{tabular}{|c|c|c|c|c|c|}
\hline \multirow[b]{2}{*}{ PERFormanCE OBJECTIVE } & \multirow[b]{2}{*}{ LIMIT } & \multicolumn{3}{|c|}{ LIMITING RESULT } & \multirow[b]{2}{*}{ CONCLUSION } \\
\hline & & SCENARIO & MEAN & $\begin{array}{c}95^{\mathrm{TH}} \\
\text { PERCENTILE } \\
\end{array}$ & \\
\hline Containment Requirements & $\mathrm{P}(\mathrm{R}>1)<0.1$ & \multicolumn{3}{|c|}{$\mathrm{P}(\mathrm{R}>1)=0.009$} & Meets Standard \\
\hline Containment Requirements & $\mathrm{P}(\mathrm{R}>10)<0.001$ & \multicolumn{3}{|c|}{$\mathrm{P}(\mathrm{R}>10)<0.0001$} & Meets Standard \\
\hline $\begin{array}{c}\text { Individual Protection } \\
\text { Requirements }\end{array}$ & $0.15 \mathrm{mSv}$ & Resident & $0.055 \mathrm{mSv}$ & $0.15 \mathrm{mSv}$ & Meets Standard \\
\hline $\begin{array}{c}\text { Groundwater Protection } \\
\text { Standard }\end{array}$ & 40 CFR 141 & \multicolumn{3}{|c|}{ No groundwater pathway in 10,000 years } & Meets Standard \\
\hline
\end{tabular}

$\mathrm{P}(\cdot)$ : Probability of an event

R: Normalized cumulative release as defined in 40 CFR 191.27

mSv: milliSievert(s)

\subsection{MANAGEMENT OF UNCERTAINTY AND WASTE INVENTORIES}

Performance assessment is an iterative process. The process begins with conservative deterministic screening models. The goal of each iteration is to reduce uncertainty in system performance. As the understanding of system performance improves and additional site characterization and monitoring results become available, conservative models can be replaced with increasingly realistic probabilistic models, parameterized with probability density functions (pdfs) that represent expected values and their uncertainty.

The current PA model in GoldSim ${ }^{\circledR}$ is probabilistic with all input parameters represented by probability distributions, thus accounting for the uncertainty in the parameter values. The parameter distributions have been developed with additional field work since 2000. The Maintenance Plan for the Area 5 PA and CA calls for additional field investigations for those parameters that are shown to be sensitive and uncertain. If a parameter is found to be highly sensitive, further investigation is justified. However, for those parameters that are uncertain but insensitive, no further data collection and reduction in uncertainty is warranted.

Comprehensive sensitivity analyses were performed for the PA model using local and global methods to explore sensitivity in model response over the entire parameter value ranges (BN, 2006). The sensitive parameters are related to plant uptake and animal burrowing. Individual radionuclide inventories were found to be insensitive; therefore, additional inventory characterization is not warranted. The relative insensitivity of the inventory highlights the robust nature of the disposal system to contain waste and protect public health and safety. 
The Area 5 RWMS PA/CA model has undergone several iterations. The probabilistic model's parameter distributions are selected to represent expected values and their uncertainty. The following conservative assumptions reflect areas with persistent parameter or model uncertainty:

- The critical group is assumed to be a resident farmer 100 meters from the site. The Area 5 RWMS is extremely remote and arid with marginal agricultural soils. The lack of attractive resources, including surface water or shallow groundwater, makes this an unlikely site for future residential development. The lack of water and suitable soils makes agriculture at the site extremely unlikely. The presence of nuclear subsidence craters in the area is also likely to remind residents far in the future of the potential presence of radioactive contamination. In addition to natural conditions, land use plans are to restrict public access in perpetuity.

- All radionuclides are assumed to be immediately available for release and transport. However, containers and waste forms are likely to delay the release of radionuclides to the near field for decades if not hundreds of years.

- The critical group, 100 meters from the site boundary, is assumed to be exposed to onsite surface soil radionuclide concentrations. Actual soil concentrations, 100 meters from the site boundary, are expected to be orders of magnitude less than onsite concentrations.

- The radon-222 emanation coefficient, a sensitive model parameter, is assumed to be uniformly distributed from 0.02 to 0.8 . This distribution reflects a maximum state of uncertainty, and the limits are the physically reasonable limits for this parameter in a solid sample. A more conservative distribution is a physical impossibility.

- The technetium plant-soil concentration ratio, a sensitive model parameter, is assumed to be lognormally distributed with a geometric standard deviation of 5.70. This implies that 95 percent of sampled values will fall within a broad 1,300-fold range. This range represents a maximum state of uncertainty reflecting spatial and temporal variation, and variability among species, climates, and soil types.

Tables A-5 and A-6 summarize the relative influence of parameters for the air pathway and all pathways. The relative influence measures the percent of the regression model variance that is explained by the parameter. The sensitivity analysis indicates that the Area 5 RWMS PA model is insensitive to waste inventory for the air pathway and all pathways TEDE for the scenarios with the highest dose.

\section{TABLE A-5. SENSITIVITY OF THE TRANSIENT VisitoR Air Pathway TEDE at 1,000 Years}

\begin{tabular}{|l|c|}
\hline \multicolumn{1}{|c|}{ PARAMETER } & RELATIVE INFLUENCE \\
\hline \hline Messor pergandei burrow volume depth distribution (b parameter) & 37.1 \\
\hline Shallow land burial radon-222 emanation coefficient & 8.73 \\
\hline
\end{tabular}

TABLE A-6. SENSITIVITY OF THE RESIDENT FARMER All Pathways TEDE at 1,000 Years

\begin{tabular}{|l|c|}
\hline \multicolumn{1}{|c|}{ PARAMETER } & RELATIVE INFLUENCE \\
\hline \hline Technetium plant-soil concentration ratio for crops & 23.9 \\
\hline Depth of the no liquid flux boundary & 5.95 \\
\hline
\end{tabular}


Table A-7 illustrates that the radon-222 flux density is moderately sensitive to the Pit 13 thorium-230 inventory and the future thorium-230 inventory.

TABLE A-7. Sensitivity OF THE RADON-222 FluX DeNSITY AT 1,000 YeARS

\begin{tabular}{|l|c|}
\hline \multicolumn{1}{|c|}{ PARAMETER } & RELATIVE INFLUENCE \\
\hline \hline Shallow land burial radon-222 emanation coefficient & 40.0 \\
\hline Pit 13 thorium-230 inventory & 26.1 \\
\hline Future shallow land burial thorium-230 inventory & 14.8 \\
\hline Pit 13 radon-222 emanation coefficient & 11.2 \\
\hline
\end{tabular}

The parameter sensitivity of the CA was assessed using the rank correlation coefficient. The CA TEDE at 1,000 years was moderately sensitive to the closure cover thickness, the maximum depth of biological activity, the technetium plant-soil concentration ratio, the chlorine plant-soil concentration ratio, the technetium-99 inventory, and the chlorine-36 inventory.

Due to the difficulty of modeling the releases from the waste containers and waste forms (e.g., corrosion rates, and dissolution and diffusive properties of the various waste forms) with any certainty, the PAs make the bounding assumption that all waste is released into the backfill soil at closure. Although not quantified, it is reasonable to assume that the integrity of some containers would significantly reduce release of waste, at least in the near term. For example, Figure A-1 shows how steel drums have been over-packed into larger steel containers.

Since no credit is taken for waste containers and waste forms, the PA results are conservative. Moreover, the results, with conservative assumptions, are far below the performance objectives, indicating further reduction of uncertainty of source material is not warranted. In summary, further data collection is not necessary to evaluate closure options for these disposal units.

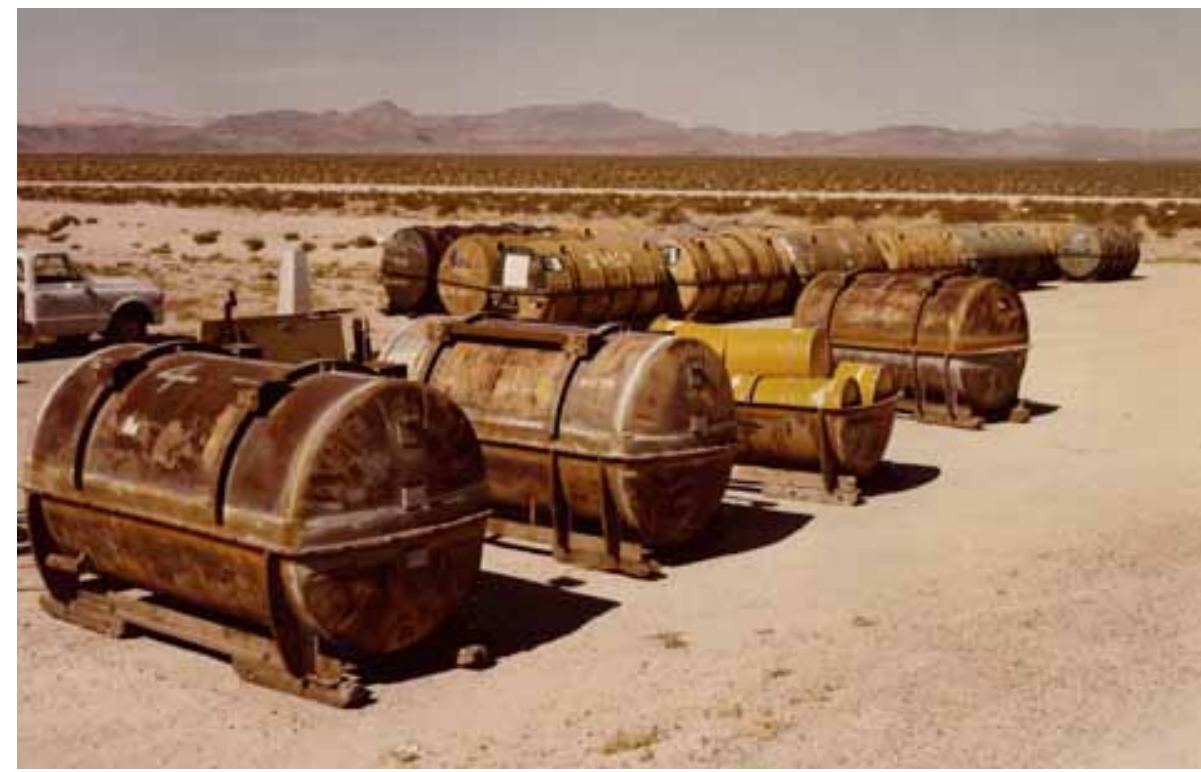

Figure A-1. SteEl Drums Over-Packed into LARger Steel Containers AT THE AREA 5 Radioactive WASte MANAGEMENT Site 


\subsection{BACKGROUND INFORMATION}

This section summarizes the waste disposal operations at the Area 5 RWMS. The site location, operational history, and waste inventory are discussed briefly. More detail can be found in the Integrated Closure and Monitoring Plan for the Area 3 and Area 5 Radioactive Waste Management Sites at the Nevada Test Site (BN, 2005d) and the Area 5 RWMS PA (Shott et al., 1998).

\subsection{SITE LOCATION}

The 92-Acre Area is located in Area 5 of the Nevada National Security Site (NNSS), which is approximately 65 miles (mi) northwest of Las Vegas, Nevada. The 92-Acre Area constitutes the southeast quadrant of the Area 5 RWMS (Figure A-2).

The Area 5 RWMS is located in a topographically closed basin approximately 14 mi north of Mercury, Nevada, in the north-central part of Frenchman Flat, and approximately 15 mi south of the Area 3 RWMS, which is in south-central Yucca Flat.

Figure A-3 shows the disposal units of the 92-Acre Area. The disposal unit names are coded. Each shallow excavation is categorized as either a "trench" (designated with the prefix " $T$ ") or a "pit" (designated with the prefix "P"), based on width. Generally pits are greater than $100 \mathrm{ft}$ wide and are large enough for a truck to turn around. The borehole designations have the prefix "GCD."

\subsection{OpERATIONAL History}

Both classified and unclassified materials have been managed at the Area 5 RWMS. Disposal records and historic records for the 92-Acre Area include the following waste types: LLW, MW, asbestiform waste, TRU waste, and mixed transuranic (MTRU) waste. The majority of the inventory is LLW. Most of the TRU and MTRU waste was placed in boreholes more than $70 \mathrm{ft}$ below ground surface. Two disposal units have been designated for asbestos waste. Much of the MW was deposited in the oldest disposal units prior to the promulgation of RCRA.

The precursor to the Area 5 RWMS, the Sugar Bunker Dump, began receiving waste by 1960 and began burying waste in January 1961, prior to the origination of federal radioactive waste management regulations and RCRA. Information on the earliest inventory and disposal practices is more general and less complete than in later years. Disposal records for some trenches are limited. Analytical profiling initially focused on radioactivity, but from process knowledge and general descriptions, it is assumed that some of the older wastes are MW.

The Sugar Bunker Dump accepted waste for surface storage as early as January 1960, and began burying waste by January 1961 when Pit No. 1 (later designated T01B) was opened. In 1965, trenches T03A, T06B, and T01A began receiving LLW. Trench T04B began receiving waste in 1970 and was the principal Area 5 disposal unit from 1970 through 1972. Trench T02B opened in July 1972. Trenches T05 and T06A were operating by 1974 and appeared to be mostly full by mid-1976. These eight shallow disposal trenches all received LLW and waste that contained hazardous constituents or suspected hazardous constituents. All eight trenches were operationally closed by 1978 . 


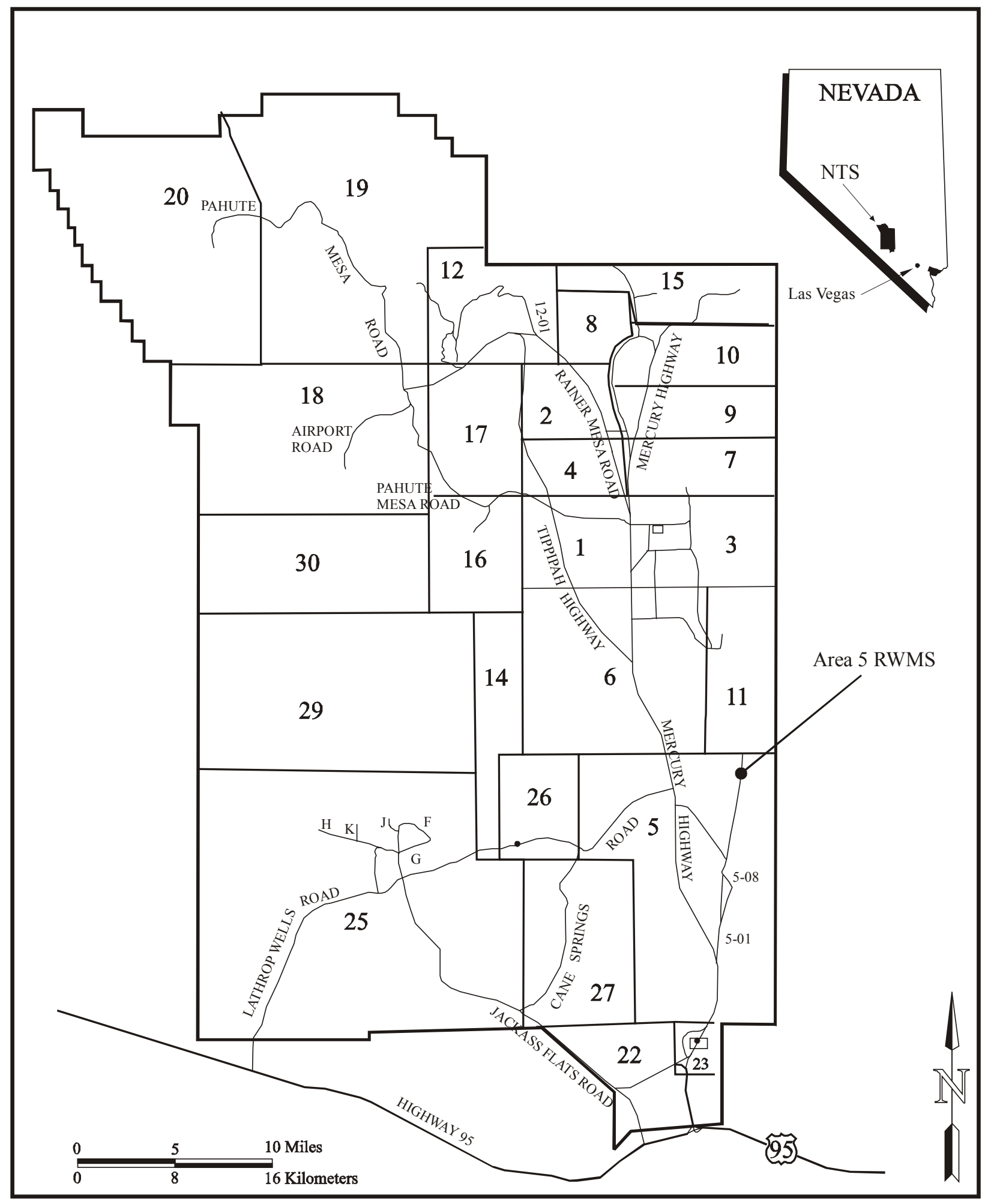

Figure A-2. Area 5 Radioactive Waste Management Site LOCATION MAP 


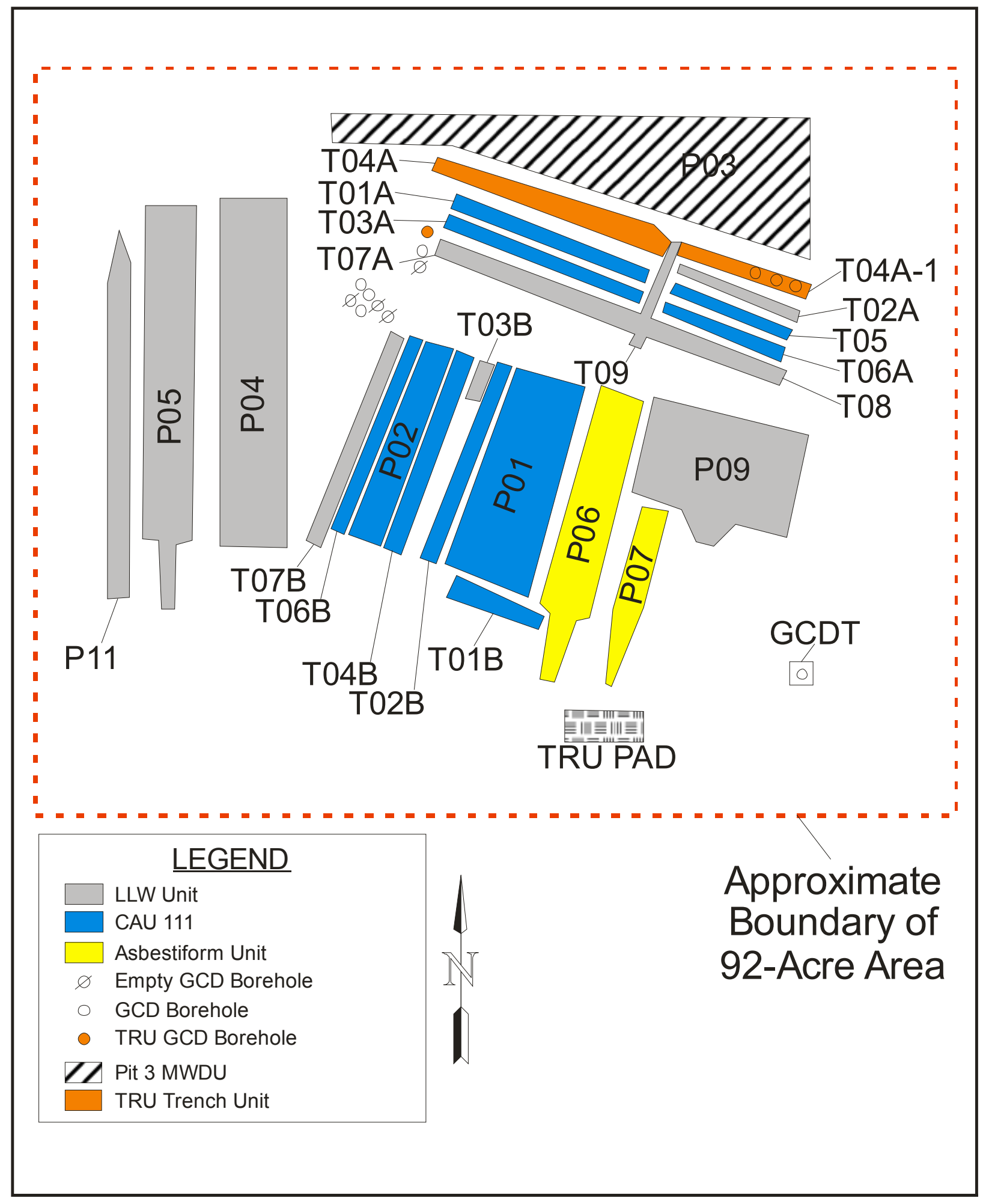

Figure A-3. 92-ACre ArEa Disposal Units 
Trench T04A began receiving waste in March 1969. In 1986, approximately 2.6 pounds of TRU waste from Rocky Flats were inadvertently disposed in trench T04A. In 1995, when trench T09 was excavated perpendicular to the T04A trench, the east end of the trench was renamed T04A-1. The T04A and T04A-1 trenches were operationally closed in August 1995.

DOE established the NNSS Waste Management Program in 1978, and the Area 5 RWMS was established on a 732-acre site incorporating the existing Sugar Bunker Dump waste cells in the southeast corner. The site began receiving LLW from offsite DOE generators. Trench T07B was opened by 1978 and received waste from Rocky Flats. There is no evidence in the disposal records of hazardous material being disposed in T07B.

Between 1978 and September 26, 1988 (when DOE O 5820.2A, "Radioactive Waste Management" [now replaced with DOE O 435.1] was promulgated), P01, P02, and T07B were filled and operationally closed.

In 1981, the Greater Confinement Disposal Test (GCDT) borehole was equipped to evaluate the feasibility of disposing high specific activity waste at the NNSS, including encapsulated radioactive sources, strontium-90 in thermoelectric generators, and drums of radioisotopes. Nine 120 -ft boreholes were drilled around the GCDT, at locations 10, 16, and $22 \mathrm{ft}$ from the GCDT, and were equipped with instruments to monitor soil temperature, soil moisture, and migration of tracers or radionuclides. The GCDT project ran for over 7 years and provided information on potential for waste migration. The GCDT was then operationally closed.

Based on results of the GCDT, 12 GCD boreholes were drilled for operational use in 1984. Three of the boreholes were drilled in the base of T04A-1. The rest were drilled from ground surface outside of the trenches. The GCD boreholes are generally $10 \mathrm{ft}$ in diameter, $120 \mathrm{ft}$ deep, and unlined, except for $10 \mathrm{ft}$ of corrugated metal surface casing. Between 1984 and 1989, 8 of the 12 GCD boreholes were used to dispose of "special case" or "orphan" wastes. These are wastes that did not meet acceptance criteria for other facilities. They have subsequently been designated as high-specific-activity LLW (waste similar to Greater-than Class C), MW, TRU waste, and MTRU waste. Detailed inventories of waste and materials in the GCD boreholes are presented in Dickman (1989) and Chu and Bernard (1991).

Although the GCDT and the Area 5 RWMS monitoring data suggest burial in these boreholes was safe and effective, disposal of waste in GCD boreholes was discontinued in 1989 when the Nevada Division of Environmental Protection (NDEP) determined the boreholes to be Class IV injection wells, which are prohibited by EPA regulations and Nevada Administrative Code (NAC). Six GCD boreholes have been filled with waste to a depth of about $70 \mathrm{ft}$ below surface and operationally closed with backfill consisting of native soil. Two boreholes have received waste and remain open (although inactive), and four boreholes are empty. In 1993, EPA clarified that underground disposal of containerized radioactive waste in geologic repositories subject to the 40 CFR 191 standards does not constitute underground injection under the EPA's underground injection control program.

CAU 111 includes the following waste disposal units, which are all operationally closed: P01, P02, T01B, T02B, T04B, T06B, T01A, T03A, T05, and T06A. There are currently three active pits in the 92-Acre Area: P03, P06, and P09. P03 is the only active MWDU. P06 and P09 contain LLW. P06 accepts asbestiform LLW, and the bottom tier is used for disposal of thorium waste. Table A-8 summarizes the types of waste, operational status, and disposal volumes of the six closure units in the 92-Acre Area. 


\subsection{RegUlatory DRIVERS FOR ClOSURE}

The closure units must comply with the closure requirements of multiple regulations. All units must comply with the requirements set forth in DOE O 435.1. A final PA and CA must be developed for the closure of the entire Area 5 facility, including the expansion area north of the 92-Acre Area. Partial unit closures are allowed under DOE O 435.1. The current PA evaluated the closure of the facility at the assumed closure date of 2028 and demonstrated compliance with the performance objectives of DOE O 435.1. The PA evaluated the radionuclide inventory disposed in the cells after September 1988 and the forecasted inventory at closure. The current CA shows compliance for all waste in all disposal units, including pre- and post-1988 inventory and TRU waste. The PA and CA evaluated the facility performance for 1,000 years after closure assuming an evapotranspirative cover. An optimization was performed in fiscal year (FY) 2009 to determine a final cover thickness for the potential final closure cover design.

For the TRU waste inadvertently disposed in trench T04A, a SA has been performed. The SA shows that leaving the TRU waste in T04A will meet the performance objectives of 40 CFR 191. The SA shows that the alternative of excavating, certifying, and shipping the TRU waste elsewhere would involve unacceptable risk to workers and prohibitive cost.

As discussed in Section 1.2, a PA was performed for GCD boreholes 1, 2, 3 and 4, which contain TRU waste. DOE approved the PA. The $70 \mathrm{ft}$ of backfill over the waste in the boreholes provides assurance that the transport of radionuclides from the waste zone to the ground surface through plant uptake and animal burrowing activity will not be possible. Minimal quantities of waste could reach the surface through diffusion and advective transport associated with upward flux. As demonstrated in the PA, the releases over a 10,000-year post-closure period under a wetter and cooler climate regime will be negligible.

The radionuclide component of waste in the legacy CAU 111 units has been evaluated under the CA and found to meet the performance objective of a 100-mrem/yr dose, as discussed in Section 1.2. The radionuclide inventories in the Pit 3 MWDU and the Asbestiform Unit have been evaluated under the PA. The hazardous component of waste in all units will perform similarly to the radionuclide component that has been modeled. Since the transport behavior of hazardous metals and volatiles is similar to that of particulate and volatile radionuclides, there is assurance that there will not be any significant release of hazardous materials to the surface soils from the waste zones through the predominantly upward pathways of bioturbation and upward liquid flux.

\subsection{WASTE INVENTORY}

Waste inventory has been established through historical studies conducted to support compliance assessments under DOE O 435.1 and closure and monitoring activities. Uncertainty of the inventory was addressed by bounding estimates in the original PA and probabilistically in the 2005 addendum. As discussed in Section 1.0, the inventory is insensitive as far as the long-term performance of the facility is concerned because of limited releases of waste from the waste zones to the atmosphere above the disposal cells. Therefore, further effort to refine the inventory estimates in order to further reduce their uncertainty is not warranted. The following sections discuss historical disposal practices and provide information regarding data archives and data warehousing efforts. They also describe the GoldSim ${ }^{\circledR}$ inventory model developed for the Area 5 RWMS, which is updated annually as new waste disposal occurs. 
Table A-8. 92-Acre Area Waste Unit Status

\begin{tabular}{|c|c|c|c|c|c|c|c|c|}
\hline $\begin{array}{l}\text { DISPOSAL } \\
\text { UNIT }\end{array}$ & $\begin{array}{c}\text { FIRST } \\
\text { RECORD }\end{array}$ & $\begin{array}{c}\text { LAST } \\
\text { RECORD }\end{array}$ & $\begin{array}{l}\text { RECORDED } \\
\text { VOLUME } \\
\left(\mathrm{FT}^{3}\right)^{\dagger}\end{array}$ & $\begin{array}{l}\text { CALCULATED } \\
\text { DISPOSAL } \\
\text { UNIT VOLUME } \\
\text { (FILLED WITH } \\
\text { WASTE) } \\
\left(\text { FT }^{3}\right)^{\ddagger}\end{array}$ & $\begin{array}{l}\text { RECORDED/ } \\
\text { CALCULATED } \\
\text { VOLUME }\end{array}$ & CURIES & $\begin{array}{l}\text { OPERATIONAL } \\
\text { STATUS }\end{array}$ & CONTENTS \\
\hline P01 & 20-Sep-78 & $25-A p r-85$ & $1.6 \mathrm{E}+06$ & $3.8 \mathrm{E}+06$ & 0.42 & $2.6 \mathrm{E}+06$ & $\begin{array}{l}\text { Operationally } \\
\text { Closed }\end{array}$ & $\begin{array}{l}\text { LLW, lead, lead shielding, barium } \\
\text { source, organic solvents }\end{array}$ \\
\hline P02 & 18-Dec-84 & 19-Nov-95 & $8.9 \mathrm{E}+05$ & $1.3 \mathrm{E}+06$ & 0.68 & $2.0 \mathrm{E}+05$ & $\begin{array}{l}\text { Operationally } \\
\text { Closed }\end{array}$ & $\begin{array}{l}\text { LLW, lead, lead shielding, barium } \\
\text { source, organic solvents }\end{array}$ \\
\hline $\mathrm{P} 03$ & 18-Sep-85 & 17-Jul-08 & $1.5 \mathrm{E}+06$ & $3.0 \mathrm{E}+06$ & 0.49 & $1.4 \mathrm{E}+05$ & Active & MW (RCRA permitted) \\
\hline $\mathrm{P} 04$ & 14-Jun-88 & 25-Oct-95 & $2.5 \mathrm{E}+06$ & $3.3 \mathrm{E}+06$ & 0.75 & $1.2 \mathrm{E}+05$ & $\begin{array}{l}\text { Operationally } \\
\text { Closed }\end{array}$ & 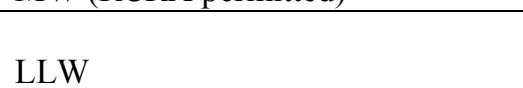 \\
\hline P05 & 15-May-95 & 27-Sep-07 & $2.2 \mathrm{E}+06$ & $4.1 \mathrm{E}+06$ & 0.53 & $2.2 \mathrm{E}+06$ & $\begin{array}{l}\text { Operationally } \\
\text { Closed }\end{array}$ & LLW \\
\hline $\mathrm{P} 06 / \mathrm{P} 06 \mathrm{~A}$ & 3-Dec-04 & 7-Feb-08 & $5.0 \mathrm{E}+05$ & $1.5 \mathrm{E}+06$ & 0.33 & $4.0 \mathrm{E}+02$ & Active & Asbestiform LLW \\
\hline P07 & 15-Sep-97 & $10-\mathrm{Feb}-03$ & $1.8 \mathrm{E}+05$ & $4.4 \mathrm{E}+05$ & 0.41 & $6.6 \mathrm{E}+01$ & $\begin{array}{l}\text { Operationally } \\
\text { Closed }\end{array}$ & Asbestiform LLW \\
\hline P09 & 10-Dec-03 & 9-Oct-07 & $2.7 \mathrm{E}+05$ & $5.9 \mathrm{E}+05$ & 0.46 & $2.9 \mathrm{E}+04$ & Active & LLW \\
\hline P11 & 27-Jan-04 & 5-Apr-05 & $1.2 \mathrm{E}+05$ & $2.2 \mathrm{E}+05$ & 0.54 & $2.9 \mathrm{E}+04$ & $\begin{array}{l}\text { Operationally } \\
\text { Closed }\end{array}$ & LLW \\
\hline T01B & 7-Jan-61 & 29-Jun-65 & $2.9 \mathrm{E}+04$ & $2.6 \mathrm{E}+05$ & 0.11 & $8.9 \mathrm{E}+00$ & $\begin{array}{l}\text { Operationally } \\
\text { Closed }\end{array}$ & $\begin{array}{l}\text { LLW, lead bricks, lead shielding, } \\
\text { cadmium, chromium, mercury, } \\
\text { organic solvents }\end{array}$ \\
\hline T02B & 5-Jul-72 & 5-Мay-78 & $3.5 \mathrm{E}+04$ & $4.7 \mathrm{E}+05$ & 0.07 & $2.8 \mathrm{E}+00$ & $\begin{array}{l}\text { Operationally } \\
\text { Closed }\end{array}$ & LLW, organic solvents, lead \\
\hline T03B & 2-Mar-92 & 10-Sep-92 & $2.4 \mathrm{E}+04$ & $5.4 \mathrm{E}+04$ & 0.44 & $2.1 \mathrm{E}+00$ & $\begin{array}{l}\text { Operationally } \\
\text { Closed }\end{array}$ & LLW \\
\hline T04B & $25-\mathrm{Feb}-70$ & 29-Nov-77 & $5.1 \mathrm{E}+04$ & $4.9 \mathrm{E}+05$ & 0.10 & $3.3 \mathrm{E}+06$ & $\begin{array}{l}\text { Operationally } \\
\text { Closed }\end{array}$ & $\begin{array}{l}\text { LLW, organic solvents, lead } \\
\text { shielding, mercury }\end{array}$ \\
\hline T06B & 1-Jul-65 & 25-May-70 & $1.7 \mathrm{E}+05$ & $3.7 \mathrm{E}+05$ & 0.45 & $1.3 \mathrm{E}+04$ & $\begin{array}{l}\text { Operationally } \\
\text { Closed }\end{array}$ & $\begin{array}{l}\text { LLW, laboratory waste containing } \\
\text { lead, cadmium and mercury, organic } \\
\text { solvents, lead bricks }\end{array}$ \\
\hline T07B & 16-May-78 & 22-Sep-78 & $1.1 \mathrm{E}+05$ & $4.3 \mathrm{E}+05$ & 0.27 & $5.3 \mathrm{E}+05$ & $\begin{array}{l}\text { Operationally } \\
\text { Closed }\end{array}$ & LLW \\
\hline
\end{tabular}


Table A-8. 92-ACre Area Waste Unit Status (Continued)

\begin{tabular}{|c|c|c|c|c|c|c|c|c|}
\hline $\begin{array}{l}\text { DISPOSAL } \\
\text { UNIT }\end{array}$ & $\begin{array}{c}\text { FIRST } \\
\text { RECORD }\end{array}$ & $\begin{array}{c}\text { LAST } \\
\text { RECORD }\end{array}$ & $\begin{array}{l}\text { RECORDED } \\
\text { VOLUME } \\
\left(\mathrm{FT}^{3}\right)^{\dagger}\end{array}$ & 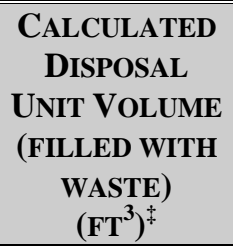 & $\begin{array}{l}\text { RECORDED/ } \\
\text { CALCULATED } \\
\text { VOLUME }\end{array}$ & CURIES & $\begin{array}{l}\text { OPERATIONAL } \\
\text { STATUS }\end{array}$ & CONTENTS \\
\hline T01A & $10-$-Oct- 65 & 19-May-76 & $1.8 \mathrm{E}+04$ & $3.6 \mathrm{E}+05$ & 0.05 & $2.1 \mathrm{E}+03$ & $\begin{array}{l}\text { Operationally } \\
\text { Closed }\end{array}$ & LLW, lead \\
\hline T02A & 7-Nov-88 & 22-Jul-93 & $6.0 \mathrm{E}+04$ & $1.3 \mathrm{E}+05$ & 0.46 & $1.4 \mathrm{E}+02$ & $\begin{array}{l}\text { Operationally } \\
\text { Closed }\end{array}$ & LLW \\
\hline T03A & 26-Aug-69 & 10-Dec-76 & $2.5 \mathrm{E}+04$ & $3.7 \mathrm{E}+05$ & 0.07 & $2.0 \mathrm{E}+03$ & $\begin{array}{l}\text { Operationally } \\
\text { Closed }\end{array}$ & $\begin{array}{l}\text { LLW, organic solvents, chromium, } \\
\text { lead }\end{array}$ \\
\hline T04A/T04A-1 & 12-Dec- 85 & 3-Aug-95 & $6.4 \mathrm{E}+04$ & $3.6 \mathrm{E}+05$ & 0.17 & $1.7 \mathrm{E}+03$ & $\begin{array}{l}\text { Operationally } \\
\text { Closed }\end{array}$ & $\begin{array}{l}\text { LLW, TRU (2.6 pounds TRU } \\
\text { inadvertently disposed in 1986) }\end{array}$ \\
\hline T05/T06A & 31-Jan-74 & 31-Jan-74 & $2.0 \mathrm{E}+03$ & $4.6 \mathrm{E}+05$ & 0.00 & $0.0 \mathrm{E}+00$ & $\begin{array}{l}\text { Operationally } \\
\text { Closed }\end{array}$ & LLW, organic solvents \\
\hline T07A/T08 & 14-May-01 & 23-Apr-03 & $6.6 \mathrm{E}+05$ & $1.0 \mathrm{E}+06$ & 0.64 & $2.5 \mathrm{E}+03$ & $\begin{array}{l}\text { Operationally } \\
\text { Closed }\end{array}$ & LLW \\
\hline T09 & 3-Aug-95 & $31-$-Oct-02 & $4.4 \mathrm{E}+04$ & $1.2 \mathrm{E}+05$ & 0.37 & $7.1 \mathrm{E}+04$ & $\begin{array}{l}\text { Operationally } \\
\text { Closed }\end{array}$ & LLW \\
\hline Unknown & 30-Jun-70 & 15-Nov-90 & $1.8 \mathrm{E}+06$ & - & - & $2.7 \mathrm{E}+05$ & - & - \\
\hline Total & 7-Jan-61 & 18-Dec-07 & $1.4 \mathrm{E}+07$ & $2.3 E+07$ & $0.58^{\S}$ & $9.5 E+06$ & & \\
\hline GCDT & 15 -Dec- 83 & 6-Mar-84 & $5.8 \mathrm{E}+02^{\S}$ & $4.3 \mathrm{E}+03$ & 0.14 & $5.3 \mathrm{E}+05$ & $\begin{array}{l}\text { Operationally } \\
\text { Closed }\end{array}$ & LLW \\
\hline GCD-01C & 1984 & 1984 & $1.4 \mathrm{E}+03^{\S}$ & $4.3 \mathrm{E}+03$ & 0.32 & $1.8 \mathrm{E}+02$ & $\begin{array}{l}\text { Operationally } \\
\text { Closed }\end{array}$ & $\begin{array}{l}\text { TRU, lithium deuteride (may contain } \\
\text { melted high explosives, lead, } \\
\text { mercury) }\end{array}$ \\
\hline GCD-02C & 1984 & 1984 & $9.8 \mathrm{E}+02^{\S}$ & $5.6 \mathrm{E}+03$ & 0.18 & $1.0 \mathrm{E}+03$ & $\begin{array}{l}\text { Operationally } \\
\text { Closed }\end{array}$ & $\begin{array}{l}\text { TRU (may contain melted high } \\
\text { explosives, lead, mercury) }\end{array}$ \\
\hline GCD-03C & 1984 & 1984 & $1.9 \mathrm{E}+02^{\S}$ & $5.6 \mathrm{E}+03$ & 0.03 & $1.1 \mathrm{E}+02$ & $\begin{array}{l}\text { Operationally } \\
\text { Closed }\end{array}$ & $\begin{array}{l}\text { TRU (may contain melted high } \\
\text { explosives, lead, mercury) }\end{array}$ \\
\hline GCD-04C & 19-Jul-85 & 14-Jan-87 & $1.3 \mathrm{E}+03^{\dagger}$ & $4.3 \mathrm{E}+03$ & 0.31 & $6.8 \mathrm{E}+00$ & $\begin{array}{l}\text { Operationally } \\
\text { Closed }\end{array}$ & LLW, TRU, lithium hydride \\
\hline GCD-05U & 26-Jun-85 & 9-Apr-87 & $3.2 \mathrm{E}+03^{\dagger}$ & $4.3 \mathrm{E}+03$ & 0.74 & $2.1 \mathrm{E}+06$ & $\begin{array}{l}\text { Operationally } \\
\text { Closed }\end{array}$ & LLW \\
\hline
\end{tabular}


Table A-8. 92-ACre Area Waste Unit Status (Continued)

\begin{tabular}{|c|c|c|c|c|c|c|c|c|}
\hline $\begin{array}{l}\text { DISPOSAL } \\
\text { UNIT }\end{array}$ & $\begin{array}{c}\text { FIRST } \\
\text { RECORD } \\
\end{array}$ & $\begin{array}{c}\text { LAST } \\
\text { RECORD }\end{array}$ & $\begin{array}{c}\text { RECORDED } \\
\text { VOLUME } \\
\left(\text { FT }^{3}\right)^{\dagger}\end{array}$ & $\begin{array}{l}\text { CALCULATED } \\
\text { DISPOSAL } \\
\text { UNIT VOLUME } \\
\text { (FILLED WITH } \\
\text { WASTE) } \\
\left(\text { FT }^{3}\right)^{\ddagger} \\
\end{array}$ & $\begin{array}{l}\text { RECORDED/ } \\
\text { CALCULATED } \\
\text { VOLUME }\end{array}$ & CURIES & $\begin{array}{c}\text { OPERATIONAL } \\
\text { STATUS } \\
\end{array}$ & CONTENTS \\
\hline GCD-06U & 16-Jul-86 & 20-Feb-87 & $2.4 \mathrm{E}+02^{\dagger}$ & $4.3 \mathrm{E}+03$ & 0.06 & $6.5 \mathrm{E}+03$ & $\begin{array}{l}\text { Closed to } \\
\text { waste, not yet } \\
\text { backfilled }\end{array}$ & LLW \\
\hline GCD-07C & 7-Jul-89 & 7-Jul-89 & $3.8 \mathrm{E}+02^{\dagger}$ & $4.3 \mathrm{E}+03$ & 0.09 & $1.9 \mathrm{E}+00$ & $\begin{array}{l}\text { Closed to } \\
\text { waste, not yet } \\
\text { backfilled }\end{array}$ & LLW \\
\hline GCD-10U & 11-Dec-87 & 27-Oct-89 & $2.0 \mathrm{E}+03^{\dagger}$ & $5.9 \mathrm{E}+03$ & 0.35 & $6.0 \mathrm{E}+05$ & $\begin{array}{l}\text { Operationally } \\
\text { Closed }\end{array}$ & LLW \\
\hline GCD Total & 23-Feb-83 & 27-Oct-89 & $1.0 \mathrm{E}+04$ & $4.3 E+04$ & 0.24 & $3.2 \mathrm{E}+06$ & & \\
\hline
\end{tabular}

$\uparrow$ - Source: Table 10 of Denton et al., 2008

$\$$ - Calculated by Area 5 Inventory GoldSim model, Version 2.022

$\S$ - Source: Chu and Bernard, 1991

\section{$\mathrm{ft}^{3}$ : cubic foot (feet)}

GCD: Greater Confinement Disposal

GCDT: Greater Confinement Disposal Test

LLW: low-level waste

MW: mixed waste

RCRA: Resource Conservation and Recovery Act

TRU: transuranic 
Waste has been accepted at Area 5 since January 1960 and placed in disposal cells since January 1961. The oldest records for the original Sugar Bunker Dump generally show load origin, a brief description of the material and containers, estimated radioactivity, and date of disposal. When necessary, a specific trench or pit can be inferred from burial date and history of the development of the disposal features. The original paper records were scanned into a digital format, and then archived. The quality of some of these scanned images is poor, and some of the data are difficult to read. There is also uncertainty as to the completeness of the scanned records.

The Radioactive Waste Management (RWM) System was developed in 1988. The RWM System tabulated basic information on a per-shipment basis for waste received from August 13, 1974, through 1992. The RWM System had design flaws, typical in early databases due to limited programming capabilities, which resulted in inconsistent entries, incomplete records, and the creation of orphan records due to poor interrelationships between the master tables and detail tables. Users of the system could modify, delete, and add data in sub-tables without changing, deleting, or adding records to the master table.

After September 30, 1992, the Low-Level Waste Information System (LWIS) Oracle application was implemented. Data in this database were stored in a single record, indexed by package. The level of characterization and burial location detail improved. Burial location was provided based on an alphanumeric grid. The tier and location within the cell were recorded. The Oracle relational database structure of the LWIS prevented some of the quality and orphan data problems that plagued the RWM System. The web applications used by generators and waste operations personnel to input data also had built-in validation features to reduce errors in the database. Bar-coding and scanning systems were implemented to facilitate package tracking.

In May 1997, the Nevada Test Site Waste Acceptance Criteria system, an enhancement to LWIS, was implemented and accepts multiple waste profiles, includes more detailed information on waste form and treatment, and is currently in use. To document and improve the accuracy of the historic waste inventory for 1961 through 1978 and make the information more usable, several historic tracking systems, including paper records and scanned records, were reviewed and cross-checked. The data were incorporated into one searchable spreadsheet. Chemical hazards were not routinely profiled before landfill regulations and RCRA were implemented; therefore, the presence of hazardous constituents and suspected hazardous constituents, and consequently the characterization of some waste as being potential MW, was inferred from general descriptions, historic photographs, and other sources. The early RWM System database covering disposal from the mid-1970s through 1992 was also checked and cross-checked with other documentation to attempt to verify locations, volumes, and characteristics of waste disposed.

Table A-8 provides information on waste buried from 1961 through December 2004. These data are from three sources: scanned paper records, the RWM System database, and the LWIS database, with slightly overlapping periods of record.

\subsection{HAZARDOUS WASTE INVENTORY}

The hazardous waste inventory has been compiled from available records for all units that contain hazardous materials. Pit 3 and the Asbestiform Unit are permitted units with well-kept records. Waste in the CAU 111 units and the GCD boreholes contain hazardous materials of uncertain quantities. Estimates of hazardous components in these units are discussed below. 


\subsubsection{CAU 111 Disposal Units}

The CAU 111 disposal units were in operation prior to the implementation of a detailed record keeping system. Table A-9 presents the Sugar Bunker Dump designations, if applicable. Waste was typically disposed in bulk form or containerized in plastic bags, steel drums, and cardboard, plywood, or steel boxes. Waste stream descriptions are limited. Typical waste stream descriptions include laundry wastes, laboratory wastes, scrap metal, contaminated soil, personal protective equipment, and samples.

Other waste streams include farm wastes from the historic EPA Farm operations, which may have included animal wastes. Many records do not indicate the exact location where the waste was disposed. Analytical waste profiling focused primarily on radioactivity but typically only stated a total curie estimate without identifying specific radionuclides. From process knowledge and general waste descriptions, it can be inferred that some wastes contain hazardous constituents. Approximately 40 percent of available records indicate hazardous constituents may be present; however, the amount of hazardous constituents present in these wastes is unknown.

Past laboratory operations at the NNSS have typically included the use of organic solvents. Waste streams denoting laboratory wastes are therefore assumed to contain an unknown amount of organic solvent. Solvents may include those typically found in laboratories (e.g., toluene, acetone, trichloroethylene, benzene, and carbon tetrachloride). Lead shielding, loose lead, and lead bricks have also been noted in disposal records. Lead shielding is assumed to be present from any record denoting the disposal of radioactive sources.

Table A-10 presents the known or suspected hazardous constituents present in each CAU 111 disposal unit. Constituents consist primarily of organic solvents and lead. Estimated waste volumes presented in Table A-8 are based on disposal unit dimensions and disposal practices. A radionuclide inventory was developed based on historic characterization data, assumptions regarding the isotopic composition of uncharacterized waste streams, and estimated waste volumes as described in the PA (BN, 2006). The approach is consistent with the methods used to estimate the pre-1998 inventory and accounts for 100 percent of the estimated waste volumes.

Table A-9. CAU 111 Cell Designations

\begin{tabular}{|c|c|}
\hline CURRENT DESIGNATION & SUGAR BUNKER DESIGNATION \\
\hline \hline P01 & none \\
\hline P02 & none \\
\hline T01B & Pit No.1 \\
\hline T02B & UF \\
\hline T04B & UD \\
\hline T06B & UA \\
\hline T01A & CA \\
\hline T03A & CC \\
\hline T05 & N-HA \\
\hline T06A & S-HA \\
\hline
\end{tabular}


Table A-10. CAU 111 Hazardous Waste Constituents

\begin{tabular}{|c|c|}
\hline DisPOSAL UNIT & KNOWN OR SUSPECTED HAZARDOUS CONSTITUENTS \\
\hline \hline P01 & lead, lead shielding, a barium source, organic solvents \\
\hline P02 & lead, lead shielding, a barium source, organic solvents \\
\hline T01B & $\begin{array}{c}\text { lead bricks, lead shielding, cadmium, chromium, mercury, organic } \\
\text { solvents }\end{array}$ \\
\hline T02B & organic solvents, lead \\
\hline T04B & organic solvents, lead shielding, mercury \\
\hline T06B & $\begin{array}{c}\text { laboratory wastes containing lead, cadmium and mercury, organic } \\
\text { solvents, lead bricks }\end{array}$ \\
\hline T01A & lead \\
\hline T03A & organic solvents, chromium, lead \\
\hline T05 & organic solvents \\
\hline T06A & organic solvents \\
\hline \hline
\end{tabular}

\subsubsection{GCD Boreholes}

Known hazardous waste in the GCD boreholes includes an estimated 60.5 kilograms of lithium hydride in borehole 4 and 45.0 kilograms of lithium deuteride in borehole 1 (Chu and Bernard, 1991). These exhibit the hazardous characteristic of reactivity. Some nuclear weapons accident residue (NWAR) waste in boreholes 1,2, and 3 may contain melted high explosives in the waste matrix. Lead and mercury are also believed to be present in the NWAR waste matrix, which exhibit characteristics of toxicity.

\subsection{INVENTORY MODEL}

The first attempt to compile the radionuclide inventory in the Area 5 RWMS disposal cells occurred in the early 1990s to support the development of the Area 5 RWMS PA and CA documents (Shott et al., 1998; BN, 2001b). The second major review and revision to the inventory estimates occurred in 2004 during the preparation of the addendum to the Area 5 PA (BN, 2006).

To support the addendum, an inventory model was developed using GoldSim ${ }^{\circledR}$ software. The model includes all historic records and accounts for uncertainty of the inventories and volumes of the disposed waste. The Area 5 Inventory Model (currently at version v2.014) estimates the inventory of radionuclides disposed in various disposal units at the RWMS.

The model is implemented in the probabilistic GoldSim ${ }^{\circledR}$ modeling platform, which allows estimation of inventory uncertainty by Monte Carlo simulation. Inventory radioactive decay and ingrowth during the operational period are also handled by native GoldSim ${ }^{\circledR}$ routines for solution of the Bateman equations. Model input data, data sources, assumptions, and methods are documented in notes, comments, hyperlinks, and graphics included within the model (BN, 2006). 
Inventory records are maintained in three sources: the waste management logbook, the Waste Management Division (WMD) database, and the LWIS. The waste management logbook is a paper record summarizing disposal at the Area 5 RWMS from 1960 until 1978. Beginning in 1976, some disposal records were entered into the WMD, an electronic database in use until 1993. From 1993 until the present, the LWIS has been in use. In addition to the database records, original records sent by the generator, survey records, and receipt records are maintained in an electronic imaging system. Records of disposals regulated under DOE O 435.1 are maintained in the WMD and LWIS. The data sources have numerous limitations (Shott et al., 1998). Records before 1994 are especially uncertain. Known problems include:

- Waste characterization before 1994 is not complete. Important radionuclides may not have been reported. In early records, radionuclides may not have been identified, and disposal is simply recorded as "curies." Some records indicate mixtures of radionuclides, such as mixed fission products (MFPs), depleted uranium, enriched uranium, plutonium, or plutonium scrap codes (PU51, PU52, or PU57).

- Inventory records are incomplete. Not all disposals were entered into waste management records. This problem occurs more commonly for older records.

- The pre-1993 relational database tables are not completely populated with data. Consequently, some records in different database tables cannot be linked and retrieved in queries. Detailed review of the database and supporting records in FY 2004 has reduced this problem significantly. It is estimated that there are approximately 3,300 packages that cannot be associated with an inventory. This represents less than 1 percent of the package records.

- The pre-1993 database radionuclide quantity data are recorded by shipment rather than by container. If containers within a shipment were sent to different disposal units, the total shipment inventory would have been recorded as disposed in each unit. This may cause multiple counting of some inventories.

\subsection{INVENTORY REVISIONS}

The 1998 PA added the activity of a limited list of fission products based on the activity recorded in the database as MFPs or disposed as strontium-90 or cesium-137. The fission product scaling factors were estimated from a literature source of fission yields for fast neutron fission of plutonium-239. The current model assigns activity to individual fission products based on the activity of only MFP or gross activity disposed. The list of radionuclides included and their scaling factors are based on an estimate of the radionuclide composition of the NNSS underground testing areas.

The 1998 PA estimated the inventory of unreported uranium isotopes by assuming an isotopic mixture for each generator. The model assumes uranium-238 and uranium-235 disposed before FY 1994 were depleted and enriched uranium, respectively. Enriched uranium is stochastically divided for each FY into low and high enrichment fractions. The level of enrichment in each category (i.e., depleted, low enrichment, high enrichment) is selected randomly for each FY. The isotopic composition of each mixture is based on a published empirical relationship between specific activity and enrichment for the gaseous diffusion process (DOE, 2004). In addition to corrections for uranium isotopes, scaling factors for fission product and transuranic contamination from recycled uranium are estimated from data provided by waste generators. 
The 1998 PA estimated the inventory of unreported radionuclides in weapons-grade plutonium disposed as PU52, an American National Standards Institute (ANSI) plutonium scrap code (ANSI, 1987). The current model performs similar revisions, but also includes calculations for PU51 and PU57. The inventory of plutonium-239 disposed before FY 1994 is assumed to represent the activity of PU52 weapons-grade plutonium, and corrections are made for other transuranic radionuclides expected to be present.

Important model inputs are set up as pdfs representing uncertainty. Input pdfs are repeatedly sampled and propagated through the model to produce a distribution of model results. The model output distributions are well represented by lognormal distributions and are entered into the Area 5 RWMS GoldSim ${ }^{\circledR}$ model as lognormal distributions with the geometric mean and standard deviation of the inventory model outputs. The assumptions made in the inventory model include:

- Waste disposed from October 1, 1988, through September 30, 2028, is regulated by DOE O 435.1. There is no official closure date for the site. The 2028 closure date is an arbitrary assumption based on an assumed 50-year operational period starting in 1978, when the Area 5 RWMS opened to offsite generators.

- Uncertainty in disposed waste inventories is poorly known. Therefore, waste uncertainty is represented by what is believed to be a conservative distribution. The annual sums of radionuclide activity disposed after October 1, 1988, are assumed to be the median of a lognormal distribution. The 99th percentile of the distribution is assumed to be equal to ten times the median (geometric standard deviation $=2.69$ ).

- Waste disposed before FY 1994 is assumed to be incompletely characterized. Radionuclide disposal rates before FY 1994 are corrected for unreported radionuclides. Activity disposed as gross activity or MFP activity is scaled to estimate individual radionuclide activities by assuming that the mixture has the same radionuclide composition as the NNSS underground testing areas (Bowen et al., 2001). The reported gross activity or fission product activity is assumed to be the activity of cesium-137, and all other fission product and activation product activity is scaled from cesium-137. The activity of uranium-238 and uranium-235 disposed before FY 1994 is assumed to be the activity of depleted and enriched uranium, respectively. Scaling factors for other uranium isotopes are based on a published relationship between specific activity and enrichment of uranium for the gaseous diffusion process (DOE, 2004). Scaling factors for minor contaminants in uranium are estimated from data provided by generators. Plutonium disposed as PU51, PU52, and PU57 are assigned individual radionuclide activities based on isotopic composition of standard plutonium scrap codes (ANSI, 1987) and typical values expected for weapons-grade plutonium.

- The WMD database does not include data for all disposed wastes. Some waste shipments were not recorded in the databases. Some database tables are not fully populated, and waste inventories cannot be retrieved by queries. The potential missing waste has been estimated by subtracting the volume of disposed waste retrieved from the databases from the physical volume of filled waste disposal units. The missing volume has been added to the inventory assuming it has the mean concentration of disposed waste. This correction is applied to pre-1988 waste only.

- The volume of future waste is based on estimates provided by waste generators. The concentration of waste in future FYs is assumed to be equal to randomly selected concentrations from past FYs. 


\subsection{STATE THE PROBLEM (STEP 1)}

Step 1 of the DQO process describes the problem to be studied and develops a CSM to gain a sufficient understanding in defining the problem.

\subsection{Problem Statement}

The problem statement for the 92-Acre Area is, "Is the site sufficiently characterized to provide the input data necessary to evaluate corrective action alternatives without the collection of additional data?"

\subsection{CONCEPTUAL SiTE ModeL}

The CSM describes the site performance (source term, releases, fate, and transport). It reflects the best interpretation of available site information and describes the most probable scenario for current conditions at the site. The CSM is based on historical documentation, personnel interviews, site process knowledge, and characterization, modeling, and monitoring data.

The CSM for the 92-Acre Area demonstrates that migration of contaminants is not occurring and that buried waste is not creating a dose to NNSS workers. The CSM also demonstrates that the buried waste does not pose a risk to future MOPs and the environment. Characterization, modeling, and monitoring data have demonstrated this, and the geology, meteorology, surface water, vadose zone, groundwater, vegetation, wildlife, soil gas, natural hazards, subsidence, and air quality of the site have been studied extensively to support the CSM. The CSM that is implemented in the facility assessments is described in Section 3.2.2, following the site characteristics discussed below.

\subsubsection{Site Characteristics}

\subsubsection{Geography}

The Area 5 RWMS is located in the northern part of the Frenchman Flat hydrographic basin, at the juncture of three coalescing alluvial fan systems (Snyder et al., 1995). Frenchman Flat is a roughly circular, topographically closed basin bounded by the Massachusetts Mountains on the north, the Buried Hills and Ranger Mountains on the east and southeast, Mount Salyer on the west, and Mercury Ridge and Red Mountain on the south. The Area 5 RWMS is at an elevation of approximately 3,180 to $3,200 \mathrm{ft}$ above mean sea level.

\subsubsection{Geology}

The mountain ranges surrounding Frenchman Flat consist primarily of Tertiary volcanic rocks and underlying Paleozoic sedimentary rocks. Erosion of the mountain ranges has resulted in deposition of a significant thickness of alluvium. Thickness of alluvium in Frenchman Flat ranges between 0 and 4,900 ft. Basalt flows are interbedded in the alluvium in the northern part of Frenchman Flat, approximately $900 \mathrm{ft}$ below the ground surface. The alluvium is underlain by interbedded Tertiary ash-flow and ash-fall tuff estimated to be over 3,900 ft thick (BN, 2005e). 
Principal faults in Frenchman Flat are the Cane Spring Fault and the Rock Valley Fault. The Cane Spring Fault is a left-lateral, strike-slip fault that strikes southwest to northeast in the northern part of Frenchman Flat, 4 mi northwest of the Area 5 RWMS. The Rock Valley Fault is a left-lateral, strike-slip fault with a minor dip-slip component (down to the north) that strikes southwest to northeast in the southern part of Frenchman Flat, about 5.5 mi south of the Area 5 RWMS. Both of these faults are active and responsible for earthquakes within the recent past.

\subsubsection{Meteorology}

The NNSS is located between the northern boundary of the Mojave Desert and the southern limits of the Great Basin Desert. This "transitional desert" is considered to be typical of either the dry mid-latitude or dry subtropical climatic zones. The climate is arid and characterized by low precipitation, a large diurnal temperature range, a large evaporation rate, and moderate to strong winds (BN, 2005f).

The average annual precipitation from 1963 to 2004 at the Well 5B meteorological station, 4 mi south of the Area 5 RWMS, is 4.92 inches (in.). Potential evapotranspiration (PET) is a measure of the exchange of water and heat between the earth's surface and the atmosphere and an important component of the water balance calculation used to evaluate the potential for precipitation to infiltrate and percolate to the waste cells. PET at the NNSS is high because of the large incident solar radiation and high average wind speeds, and occurs at a potential, or energy-limiting, rate. Average annual PET from 1995 through 2004 was 60.2 in., many times the average precipitation rate.

The open and sparsely vegetated Frenchman Flat basin is windy and enhances evaporation rates. In 2004, the average daily wind speed was 5.8 miles per hour ( $\mathrm{mph}$ ), and the maximum gust measured was $45.6 \mathrm{mph}$. Winds are primarily from the southwest during spring and summer months and from the north during winter months. Wind speeds tend to be greatest in spring.

\subsubsection{Surface Water}

No permanent surface water is present within Frenchman Flat, with the exception of small artificial impoundments and Cane Spring, which issues from a perched aquifer recharged from infiltration through fractures in the nearby mountains. Cane Spring is approximately $9 \mathrm{mi}$ southwest of the Area 5 RWMS. Alluvial fans within Frenchman Flat are cut by numerous arroyos that drain storm runoff to the playa. Water that accumulates on the playa typically evaporates or infiltrates, or both, within a short period of time. Frenchman Playa is approximately $4 \mathrm{mi}$ southeast of the Area 5 RWMS.

Flood analyses for the 25-year and 100-year storm events have been conducted for the Area 5 RWMS (Schmeltzer et al., 1993). Although the southwest corner of the Area 5 RWMS is within the 100-year floodplain, most of the 92-Acre Area is outside the floodplain delineation. Disposal units within the Area 5 RWMS are protected from offsite flooding events by a RCRA-compliant berm and channel system capable of conveying flood flows from a 25-year, 24-hour storm event. 


\subsubsection{Vadose Zone}

Several studies and models have been completed to characterize the stratigraphy and physical properties of the unsaturated zone in Area 5, the physical properties of the existing operational covers, and the potential for movement of water through the vadose zone (Albright et al., 1994; Blout et al., 1995; BN, 2005b; BN, 2005c; BN, 2005e; REECo, 1993a; REECo, 1993b).

Time-domain reflectometry (TDR) data from automated waste cover monitoring systems provide direct measurement of moisture content in soil. Measured volumetric soil water content at the P03 and P05 floor sensors has consistently been approximately 10 percent, which indicates that moisture has not migrated more than $4 \mathrm{ft}$ below the waste (BN, 2005f).

The Area 5 Weighing Lysimeter Facility, located approximately 1,300 ft southwest of the Area 5 RWMS, consists of two precision weighing lysimeters. One lysimeter is vegetated with native plant species at the approximate density of the surrounding desert. The other is not vegetated to simulate the bare operational waste covers at the Area 5 RWMS. Each of the weighing lysimeters is instrumented with TDR probes to measure volumetric soil-water content at depths ranging from 4 to $67 \mathrm{in}$. Due to transpiration, the vegetated lysimeter is significantly drier than the bare-soil lysimeter. Wetting fronts at the vegetated lysimeter have not exceeded $4 \mathrm{ft}$ in depth except in the spring of 2005, in comparison with the bare-soil lysimeter, where moisture reached the base of the lysimeter at $6.6 \mathrm{ft}$ and began to pond.

Model simulations calibrated to the weighing lysimeter data set indicate that once vegetated, drainage through a cover is essentially eliminated (Desotell et al., 2006). Climate and vegetation strongly influence the movement of water in the near-surface alluvium (upper $6.5 \mathrm{ft}$ ). Except for periods following precipitation events, water content in the near-surface region is low. Below this region is a zone where steady upward movement of water is occurring, primarily via evaporation (Tyler et al., 1996). This zone extends to depths as great as 10 to $131 \mathrm{ft}$. Below this zone, water potential measurements indicate the existence of a static zone between approximately 131 and $295 \mathrm{ft}$ below ground surface (Shott et al., 1998). In this static zone, essentially no vertical liquid flow is currently occurring. Below this static zone, flow is downward, due to gravity.

In the unlikely event contaminants migrate below the static region to where vertical gravitational flow is possible, movement to the groundwater would be extremely slow. Conservative median modeling estimates of the time it would take water to move from beneath the static region (approximately $300 \mathrm{ft}$ below ground surface) to the groundwater (approximately $720 \mathrm{ft}$ below ground surface) are in excess of 50,000 years (Shott et al., 1998). Under model assumptions, there is a 99 percent probability that the time would exceed 30,000 years (Shott et al., 1998).

\subsubsection{Groundwater}

Frenchman Flat is in the Ash Meadows sub-basin (Laczniak et al., 1996) of the Death Valley Regional Flow System, a major hydrologic subdivision of southern Great Basin. Groundwater primarily flows through the lower carbonate-rock aquifer and discharges along a line of springs in Ash Meadows. Water levels within the lower carbonate-rock aquifer indicate that the gradient is nearly flat (less than $1.6 \mathrm{ft}$ per mi), and calculated groundwater flow velocities have generally been less than $0.5 \mathrm{ft}$ per year. The depth to the static water level in Frenchman Flat ranges from $690 \mathrm{ft}$ near the central playa to more than 1,150 ft at the northern end of the valley. 
Groundwater from the uppermost aquifer (Laczniak et al., 1996) is sampled semiannually. Water samples collected from three wells are analyzed for radioactive and nonradioactive constituents. Groundwater monitoring data are presented in detail in the annual groundwater monitoring data report $(\mathrm{BN}, 2005 \mathrm{~g})$. All groundwater sampling data to date indicate that the groundwater in the uppermost aquifer is unaffected by RWMS or DOE weapons testing activities.

The potential for groundwater quality impacts from the Area 5 RWMS waste storage is low because vertical movement of percolating water is limited by many factors including climate and geology. Except for short-term events, evapotranspiration is much higher than precipitation. There is insignificant stormwater runoff, there has been no apparent recharge in the immediate vicinity, and there are no known potential conduits deeper than the GCD boreholes that could speed transmission of potential leachate to deeper strata.

\subsubsection{Vegetation (Flora) and Wildlife (Fauna)}

The nature and distribution of plants and animals and their ecological interactions are of interest both as agents of contaminant transport and as potential receivers of contaminants. They have a complex role in potential transport of water and radioactive particles through soil landfill covers.

The type, maturity, and density of vegetation affect the potential for evapotranspiration, soil erosion, and rainwater infiltration (Hunter and Medica, 1989; Ostler et al., 2000). Rooting depth is tied to soil moisture availability. Shrubland species at the Area 5 RWMS have shallow root systems, and observed root depths are generally less than $6.6 \mathrm{ft}$ (Foxx et al., 1984a; 1984b; Hansen and Ostler, 2003). The potential for plants to enhance downward movement of water towards buried waste is offset by their use of water to live and grow. Decomposition of roots provides channels for water and vapor and may enhance infiltration and percolation through the rooting depth, but plants remove water from the soil, store it in biomass, and transpire it back to the atmosphere. Plant evapotranspiration minimizes potential water transport through the cover, and the plant canopy and roots help control erosion of the surface by wind and rain.

Because plant roots absorb radionuclides from soil water, draw radionuclides up into leafy parts of the plant, and potentially release some to the atmosphere via transpiration, vegetation can also be a factor in the movement of radionuclides in the near surface. Biota monitoring has mainly focused on sampling vegetation for tritium due to its high mobility as tritiated water. Vegetation from on and near waste covers, as well as vegetation from control areas far from waste covers, is usually sampled in mid-summer. Plant water is extracted from the vegetation samples by room temperature vacuum distillation and analyzed by liquid scintillation for tritium. If tritium concentrations in vegetation are exceedingly high, or if animal burrows on or near waste covers are observed in significant numbers, wild animals and soil from animal burrows may be sampled. Vegetation sampling may be limited year to year, depending on rainfall and waste cover operations during operational closure. Traces of tritium have been found in plant tissue.

Fauna have a potential role in transport of radioactive contaminants through burrowing and the food chain. Fauna within the Mojave Desert plant communities at Frenchman Flat are diverse. Ants and termites are the most numerous burrowing animals on the NNSS (O'Farrell and Emery, 1976). Vertebrates are less numerous and diverse and include game and burrowing species. Both small and large burrowing mammals are present in the areas of the Area 5 RWMS. Rodents are the most common of the mammalian species on the NNSS (Allred et al., 1963). 
The depth of burrowing is tied to soil conditions and rooting depths. Most animals at the NNSS burrow in the upper $10 \mathrm{ft}$ of soil. Termites have been known to excavate as deep as $20 \mathrm{ft}$; however, because roots are their primary food source, burrowing depths are also closely related to rooting depth (Cochran et al., 2001). Vertebrate animal burrows at the RWMS tend to be below shrubs. Most of the burrows are 2 to $4 \mathrm{in}$. in diameter and extend approximately $1 \mathrm{ft}$ below ground surface.

\subsubsection{Soil Gas}

Monitoring of tritium concentrations in soil gas at multiple depths over time provides key data for evaluating the rate of vertical migration of radionuclides. Gas-phase tritium monitoring has been conducted via soil-gas sampling at GCD-05U since 1990. This disposal unit has a large tritium inventory (2.2 million curies at time of disposal) and is instrumented with two strings of nine soil-gas sampling ports buried at depths ranging from 10 to $120 \mathrm{ft}$ below surface. Tritium sampling at GCD-05U provides a direct measure of tritium migration from waste packages with time due to degradation of waste containers and the natural transport processes of advection and diffusion. Results from 1990 through 2004 indicate that soil-gas tritium concentrations have gradually increased at depths between 50 and $120 \mathrm{ft}$, but vertical migration is extremely slow.

\subsubsection{Natural Hazards and Subsidence}

Subsidence is expected to occur as waste and cover fill materials settle through time.

Differential settling, especially across disposal feature margins, can cause cracks at ground surface, which could provide vertical migration pathways for water, vapor, and mobile contaminants. Depressions, which can retain water after rainstorms, allow more water to infiltrate and more plants to grow on the landfill covers. Large-volume groundwater withdrawals could also cause regional subsidence as the alluvial aquifer is dewatered, should groundwater pumping increase substantially in the future.

Many factors affect potential subsidence of the landfill covers, including structural integrity of containers, how containers were packed into units, weight of stacked containers and soil covers, void space within and around containers, and compaction of soil covers. Subsidence monitoring is conducted monthly at all disposal units.

Natural hazards that may affect the disposal areas include seismic activity and flooding. While these natural and incidental hazards are unpredictable, studies have been done to determine the relative risk of these hazards impacting the disposal sites, and measures have been implemented to reduce the risk of containment failure. Active faults nearest the Area 5 RWMS are within the Rock Valley fault system (O’Leary, 1996). These faults are over $3 \mathrm{mi}$ from the facility. Effects of future seismic events have been judged to not significantly impact the waste isolation performance of the Area 5 disposal facility (BN, 2006).

Three watersheds make up the drainage area that could impact the Area 5 RWMS. The southwest corner of the Area 5 RWMS is within a 100-year flood hazard zone. This zone is defined to have 0.01 percent probability that a flood with a depth of flow greater than $1 \mathrm{ft}$ could occur within any given year. Other parts of the Area 5 RWMS are within an area referred to as Zone X, a flood-hazard designation that corresponds to areas outside of the 100-year flood hazard zone. Sheet flow resulting from a 100-year, 6-hour precipitation event is anticipated to be less than $1 \mathrm{ft}$ deep (Schmeltzer et al., 1993). In the mid-1990s new channels and berms were designed and built. The berm system is adequate to handle a 25-year, 24-hour storm. 


\subsubsection{Air Quality}

Air monitoring is conducted to confirm that RWMS activities do not result in significant radionuclide concentrations above background. Air quality results are summarized in the annual Waste Management Monitoring Report (BN, 2005f). The tritium concentration in the air near the RWMS, compared to background concentrations at the NNSS, is an indicator of how well the waste disposal cells are mitigating migration of volatile radionuclides from waste cells. Tritium concentrations at the Area 5 RWMS are less than the DOE Derived Concentration Guide (DCG) for tritium. According to DOE O 5400.5, "Radiation Protection of the Public and the Environment," the DCG is the concentration of a radionuclide in the air that could be inhaled for 1 year and not exceed the DOE radiation standard of $100 \mathrm{mrem} / \mathrm{yr}$ committed effective dose equivalent to the public (DOE, 1993).

Air particulate samples are collected weekly from monitoring stations near the RWMS and are screened for gross alpha and gross beta activity to provide early detection of any changes. Monthly composites of filters from each sampling location are analyzed for americium, plutonium, and gamma emitters. Air particulate monitoring data indicate that radionuclide concentrations in air at the RWMS are not above those of other nearby stations. The concentrations of all the analytes in samples from the RWMS are similar to concentrations elsewhere at the NNSS.

Ionizing radiation from both natural and man-made sources is measured quarterly through a network of thermoluminescent dosimeters. Data collected from 1998 through 2004 indicate that direct radiation exposure at the Area 5 RWMS is low. Levels at all the sites were below 1.8 milliroentgens per day ( $\mathrm{mR} /$ day). The average exposure rate at background NNSS locations is $0.30 \mathrm{mR} /$ day $(\mathrm{BN}, 2005 \mathrm{f})$.

\subsubsection{Facility Assessments Conceptual Model}

The following discussion of the conceptual model is a summary from the second addendum to the PA (BN, 2006). Further details, including the implementation of the conceptual model in GoldSim $^{\circledR}$ and the analyses performed to identify the sensitivities, are included in the PA. The 1998 PA model of unsaturated flow in the vadose zone was developed to understand liquid fluxes capable of transporting radionuclides. The model, based primarily on observed water potential and chloride profiles, hypothesized four regions of liquid flow in the vadose zone (Figure A-4). Zone boundaries are approximate and may vary from location to location within Frenchman Flat. In Zone I, a near-surface zone approximately $115 \mathrm{ft}$ thick, the water potential indicates a potential for upward liquid flux. Zone II, occurring from approximately 115 to $295 \mathrm{ft}$, is a static region with negligible liquid flux. Zone III, an intermediate region with downward liquid fluxes driven by gravity, occurs from approximately $295 \mathrm{ft}$ to within a few inches of the saturated zone. The final region, Zone IV, which is a few inches thick, is a transitional zone between the vadose zone and the saturated zone where water potential and flow are negligible. 


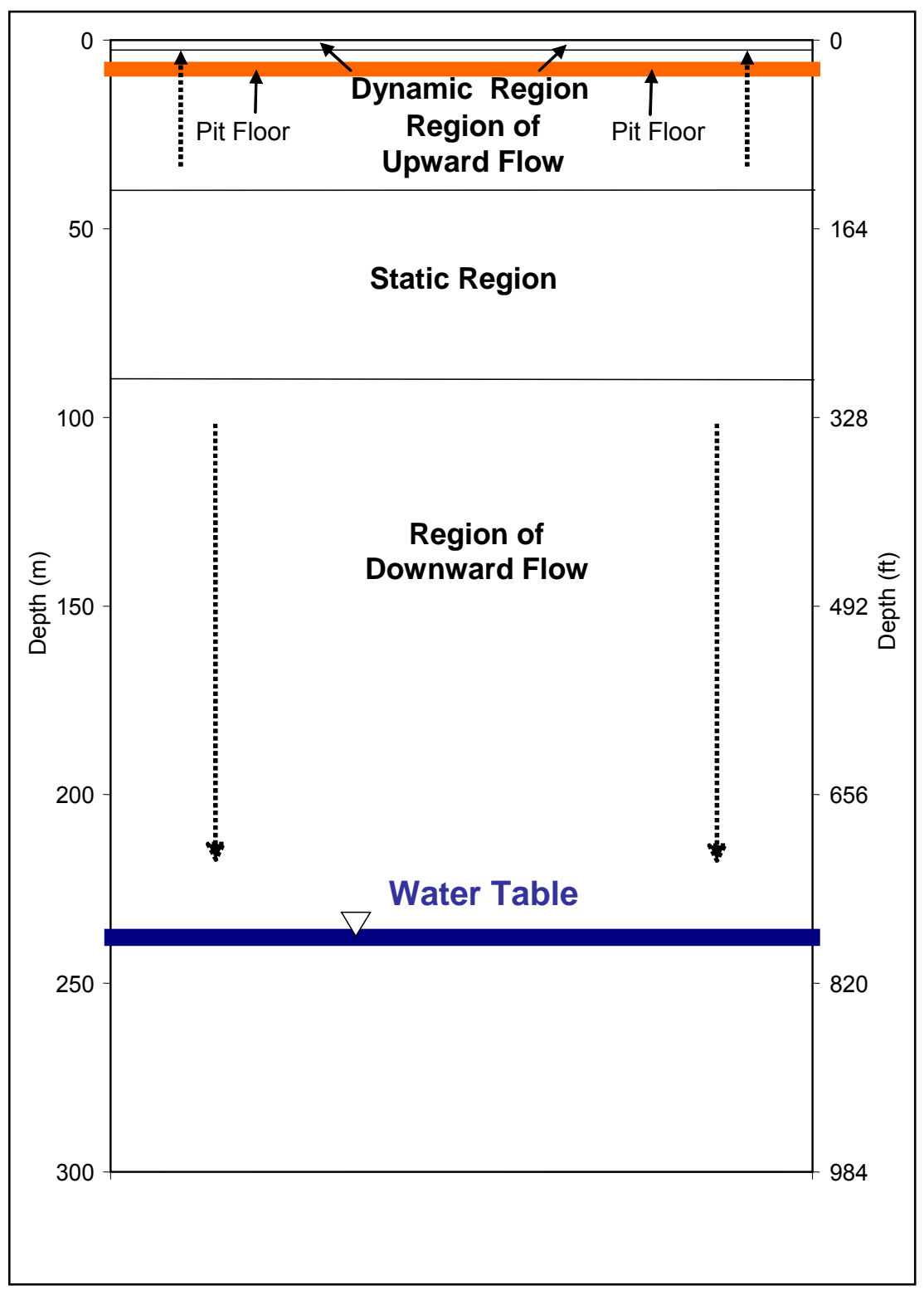

Dynamic Region: Magnitude and direction of liquid fluxes are variable and determined by episodic infiltration, evapotranspiration, and processes of biotic transport. The no-flux boundary is located at mean depth of $6 \mathrm{ft}$.

Zone I, Region of Slow Upward Flow: Region where the combination of low precipitation and high potential evapotranspiration leads to a dry zone, inducing upward flow of pore water in the unsaturated zone from as deep as about $100 \mathrm{ft}$. Mean upward flux is $0.004 \mathrm{~mm} / \mathrm{yr}$.

Waste zone located in region of upward flow.

Zone II, Static Region: Region of no vertical liquid flow (balance of matric suction and gravitational forces). The thickness and the depth below the surface of this region changes with the physical/textural properties of alluvium and in situ water content.

Zone III, Region of Slow Downward Flow: Region of steady downward flow (increased water content allows downward drainage). Water in the vadose zone is currently recharging the water table most likely infiltrated during past pluvial climate cycles.

There is no aerially distributed recharge to the groundwater table under current conditions.

\section{Figure A-4. PA Model of UnSATURATEd Flow in the Vadose Zone}


Zone I includes a dynamic region in the upper few feet of the vadose zone where the water potential gradient periodically reverses as precipitation infiltrates and is returned to the atmosphere by evapotranspiration. A strong upward potential for flow is maintained in Zone I by the roots of xeric desert plants. Although there is a potential for upward flow in Zone I, the soil is normally so dry that liquid water advection is very slow. In the very near-surface, where plant roots maintain low soil moisture content, upward water movement occurs predominantly in the vapor phase (and through plant roots), and the upward advection of soluble radionuclides may become negligible. The boundary where upward liquid advection rates approach zero is referred to as the no-flux boundary (NFB) in the PA model.

The large accumulation of chloride in Zone I below $6.6 \mathrm{ft}$ indicates that transient infiltration events are impeded above this depth and returned to the atmosphere by evapotranspiration. Assuming a constant atmospheric chloride source and downward liquid advection, the observed near-surface chloride accumulation below the root zone is estimated to require from 10,000 to 15,000 years to form, which corresponds with the end of the last pluvial period, approximately 8,000 to 15,000 years ago (Tyler et al., 1996; Walvoord et al., 2002a).

The chloride accumulated throughout the entire profile at pilot wells UE5PW-1 and UE5PW-3 suggests that infiltration at these locations has not reached the water table for 95,000 to 110,000 years (Tyler et al., 1996). The chloride profile at UE5PW-2 suggests that the sub-root zone chloride bulge was flushed from this profile at some time before 15,000 years ago, indicating that spatially variable recharge occurred during an earlier pluvial period. The chloride profiles in the vadose zone near the Area 5 RWMS suggest that recharge through the alluvium ended after the last pluvial period when the climate became drier and woodlands were replaced by more xeric desert shrubs.

The 1998 PA estimated upward liquid flux in Zone I using a process model. The estimated flux, $5 \times 10^{-6}$ millimeters per year $(\mathrm{mm} / \mathrm{yr})$, was so low that upward liquid advection of radionuclides was not included in the 1998 PA release and transport model. Diffusion of radionuclides in the liquid phase was considered as an alternative upward release pathway, but was assumed to be negligible at the low water contents in the near-surface based on theoretical considerations and literature reports. Although upward liquid advection and diffusion were included in the 1998 PA conceptual model, their rates were assumed to be so low as to be negligible, and quantitative values were not included in the release and transport mathematical model.

\subsubsection{Recent Deep Vadose Zone Research and Development Results}

The understanding of how matric potential and chloride profiles develop in thick desert vadose zones has advanced since the 1998 PA. Although conditions in thick vadose zones appear to be stable over long periods, the upward liquid flux in Zone I and the downward liquid flux in Zone III suggest that the system cannot be at steady-state. Previous interpretations of the observed profiles had conceptual inconsistencies. Upward flow in Zone I and downward flow in Zone III cannot be maintained unless there is a water source in Zone II. If the source of water in Zone II is transient surface infiltration, the near-surface chloride accumulation is not expected. The chloride accumulation suggests that recharge is not occurring. However, purely physical models (i.e., without plants) that assume no recharge cannot simulate the large negative matric potentials observed in the near-surface. 
Walvoord et al. (2002b) have developed and tested the Deep Arid System Hydrodynamic (DASH) model for thick desert vadose zones that supports the 1998 PA conceptual model and resolves apparent inconsistencies between the observed water gradients and chloride profiles. The DASH conceptual model assumes a constant, strongly negative matric potential maintained below the root zone by desert vegetation, a mean annual geothermal temperature gradient, and allows water vapor movement driven by temperature (thermal vapor flux) and matric potential (isothermal vapor flux). Implementing this model with the finite element heat and mass transfer (FEHM) model, Walvoord et al. (2002b) have shown that matric potential and chloride profiles similar to those observed at the Area 5 RWMS can be maintained at equilibrium. The model identifies water vapor driven upward from the water table by the geothermal temperature gradient as the probable source of water to the deep vadose zone. The water fluxes are extremely small, and the profiles are not currently at equilibrium. Zones II and III are most likely still draining infiltration that occurred during prior pluvial periods.

Using surface boundary conditions for infiltration and root-zone matric potentials based on a 110,000-year paleoclimate reconstruction for southern Nevada, Walvoord et al. (2002a) were able to simulate matric potential and chloride profiles observed at the Area 5 RWMS pilot wells, UE5PW-1, UE5PW-2, and UE5PW-3. Sub-root zone upward liquid fluxes were estimated to range from $2 \times 10^{-5}$ to $1 \times 10^{-3} \mathrm{~mm} / \mathrm{yr}$ under the current climatic conditions. The hydraulic response time, the time required for an e-fold $\left(1-\mathrm{e}^{-1}\right)$ change in matric potential from the initial to steady-state profile, was estimated to be 300,000 years for Frenchman Flat, again suggesting that the pilot well profiles are not at equilibrium, but drying very slowly.

\subsubsection{Recent Shallow Vadose Zone Research and Development Results}

A key assumption of the DASH model is that plants maintain a large negative matric potential in the root zone and extract all infiltrating water. Andraski (1997) has investigated water movement in the upper $16 \mathrm{ft}$ of the vadose zone in the Amargosa Desert. On a vegetated native soil plot, no evidence of water accumulation or percolation below $3.3 \mathrm{ft}$ was observed over a five-year period. Non-vegetated plots showed a small increase in water storage and percolation to depths of $6 \mathrm{ft}$.

The Area 5 weighing lysimeter facility, located approximately 1,300 ft southwest of the Area 5 RWMS, has been continuously recording water storage in two 6.6-ft-deep precision weighing lysimeters since March 1994. One lysimeter has been revegetated with native plants, and the other is maintained bare. No increase in water storage has been observed for the vegetated lysimeter. Early increases in water content for the vegetated lysimeter were caused by irrigation performed to establish native plants. The bare lysimeter shows a slowly increasing trend in water storage. Although water has never been observed to drain from the bottom of either lysimeter, it is likely that a small fraction of infiltrating precipitation will eventually drain from the bare lysimeter (BN, 2005f).

Water content in the near-surface has also been monitored at the Area 5 RWMS since 1995. Water content monitoring began with neutron moisture measurements in boreholes at Pit 3 (P03). Beginning in 1998, automated water content monitoring systems using TDR probes were installed in the operational cover and floor of Pit 3 and Pit 5, in the cover of Pit 4, and outside the Area 5 RWMS near UE5PW-1. With the installation of the automated TDR system, neutron moisture logging has been discontinued. 
Automated TDR moisture content monitoring in the weighing lysimeter indicates that wetting fronts penetrate a short distance in the vegetated lysimeter before being evaporated. Wetting fronts, including some occurring during the particularly wet fall of 2004, are not observed to penetrate below $4.3 \mathrm{ft}$ in the vegetated lysimeter. Percolation to greater depths may occur in unvegetated areas, including operational covers at the Area 5 RWMS. Wetting fronts from the fall of 2004 have been observed to penetrate to a depth of $4.9 \mathrm{ft}$ at Pit 3 and Pit 4 (BN, 2005f). Monitoring systems installed below Pit 3 and Pit 5 continue to show constant water contents, indicating that no water has percolated through waste.

\subsubsection{Current Vadose Zone Conceptual Model}

The vadose zone conceptual model implemented in the Area 5 RWMS GoldSim ${ }^{\circledR}$ model is similar to the 1998 PA model. The mathematical implementation of the model in the Area 5 RWMS GoldSim ${ }^{\circledR}$ model includes a number of refinements and additional detail for the shallow vadose zone. Both models assume Zone I has a potential for upward transport of soluble radionuclides by upward liquid advection and diffusion in the liquid phase. The 1998 PA assumed that the upward liquid flux and liquid diffusion rate were negligible in Zone I. The Area 5 RWMS GoldSim ${ }^{\circledR}$ model divides Zone I into two regions with different upward liquid fluxes. Above the NFB, assumed to be at a mean depth of $6.6 \mathrm{ft}$, upward liquid flux is assumed to be zero. Below the NFB, a pdf of upward liquid fluxes is assumed. Complete documentation of the vadose zone conceptual model is found in the Area 5 RWMS GoldSim ${ }^{\circledR}$ model and its references (BN, 2006).

Upward liquid fluxes cannot be directly measured under the dry conditions at the Area 5 RWMS. Since preparation of the 1998 PA, upward water fluxes ranging over nearly six orders of magnitude have been estimated by several different modeling methods. Water balance and stable isotope methods have produced the highest estimates ranging from 0.1 to $1 \mathrm{~mm} / \mathrm{yr}$ (Tyler et al., 1999). Physical models of liquid flow have produced lower estimates ranging from $5 \times 10^{-6}$ to $0.2 \mathrm{~mm} / \mathrm{yr}(\mathrm{BN}, 2001 \mathrm{~b}$; Shott et al., 1998). The Area 5 RWMS CA (BN, 2001b) and Area 3 RWMS PA/CA used a mean water flux (vapor and liquid flux) of $0.3 \mathrm{~mm} / \mathrm{yr}$ and $0.2 \mathrm{~mm} / \mathrm{yr}$, respectively, estimated using stable isotope methods (Chapman, 1995; 1997).

Although each of these methods has its advantages and disadvantages, the physical models are considered to give the most reliable estimates. The water balance and stable isotope methods are suspected to produce overestimates because they calculate average rates over long time intervals when rates were likely changing. The stable isotope method assumptions may also be violated as applied at the Area 5 RWMS (Wolfsberg and Stauffer, 2003). The physical model results are uncertain because of uncertainty in the unsaturated hydraulic conductivity at low moisture contents. Unsaturated hydraulic conductivities are difficult to measure at the low Area 5 moisture contents. Most past efforts to estimate upward liquid fluxes with physical models have used unsaturated hydraulic conductivities predicted from moisture retention data.

The simulations of Wolfsberg and Stauffer (2003) are assumed to be the best available estimate of upward liquid flux. Their simulations consider a full range of surface boundary conditions and material properties, including unsaturated hydraulic conductivities measured at expected water contents. The 32 realizations of upward liquid flux from the Wolfsberg and Stauffer (2003) simulations were used to develop an upward liquid flux pdf for the Area 5 RWMS GoldSim $^{\circledR}$ model. The development of the upward liquid flux pdf is documented in the Area 5 RWMS GoldSim ${ }^{\circledR}$ model and its references (BN, 2006). 


\subsubsection{Conclusions}

The Area 5 RWMS is well suited for the isolation and disposal of waste. The site is located in an access-controlled government facility many miles from residential populations. The site has a windy, arid climate. Average annual PET is 60.2 in., many times the average precipitation rate of 4.92 in. On an annual basis, even in wet, cool years, evaporative demand is high.

The site is far from surface waters. Surface runoff and run-on is insignificant, and engineered berms provide protection from a 25-year flood. Risks of significant earthquake hazards are low. Minor subsidence of the ground surface above the edges of waste containers and the margins of the cells is likely; however, this localized subsidence can be mitigated through monitoring and maintaining the covers to preclude cracks or depressions from allowing infiltration of rainwater. Plant evapotranspiration minimizes potential water transport through the cover, and the plant canopy and roots help control erosion of the surface by wind and rain.

The vadose zone below the waste cells has low water potentials, low unsaturated hydraulic conductivity rates, and ample water storage capacity. Therefore, the potential for significant downward transmission of water is extremely low. Below this zone, water potential measurements indicate the existence of a static zone where essentially no vertical liquid flow is currently occurring. Conservative modeling estimates suggest it would take more than 50,000 years for water to move from beneath the static region to the groundwater, which is over $700 \mathrm{ft}$ below ground surface. If water were to carry contaminants to the groundwater, water levels indicate that the gradient is nearly flat, and calculated groundwater flow velocities have generally been less than $0.5 \mathrm{ft}$ per year. Effectively, there is no groundwater pathway, and the potential for groundwater contamination from waste disposal activities at the Area 5 RWMS is negligible.

The majority of the waste inventory is LLW, and much of the LLW contains radionuclides that will decay significantly over the next several decades. Much of the radioactivity in the waste inventory is in relatively immobile forms, with the exception of tritium, a volatile radionuclide that can readily move with water.

The CSM indicates that contaminants are not readily released or transported. The waste acceptance criteria, packaging requirements, monitoring, climate characteristics, and other factors minimize the potential for release and transport of contaminants. Assessments and analyses indicate that the Area 5 RWMS will meet the DOE regulatory performance criteria for the 1,000-year compliance period. Predicted potential human exposures for various future potential land-use scenarios are negligible. 


\subsection{IDENTIFY THE GOAL OF THE STUDY (STEP 2)}

Step 2 of the DQO process identifies the questions the study will attempt to resolve and what actions may result. The goal of the study is to answer the following questions satisfactorily.

1. Do historical information and monitoring data adequately allow for the development and evaluation of corrective action alternatives? If so, then the corrective action alternatives will be developed and evaluated to identify the risks and costs associated with each.

2. If not, is it possible to develop such data? If the historical information and monitoring data do not adequately allow for the evaluation of corrective action alternatives, a sampling strategy and corresponding DQOs will be developed and presented to NDEP. 


\subsection{IDENTIFY INFORMATION INPUTS (STEP 3)}

Step 3 of the DQO process identifies the information needed to address the goals of the study.

\subsection{INFORMATION NEEDS}

All information needed to develop and evaluate corrective action alternatives is summarized below. These data have been collected in association with various studies and from modeling that has been conducted to support development of a closure strategy and monitoring programs. Corrective action alternatives in addition to those listed below may be developed; however, the data needs listed below are expected to encompass any additional alternatives that may be developed.

- Closure-in-place data needs

- CSM in sufficient detail that will allow for all pathways modeling to be completed

- Understanding of operational history (e.g., waste containerization, waste placement, disposal dates)

- Waste volumes and inventory (radiological and hazardous)

- Clean-closure data needs

- Sufficient information regarding waste volumes and inventory (radiological and hazardous) to estimate cost, worker dose, transportation risk, and dose to the public

- Identification of disposal capacity sufficient for the projected waste streams that will be generated in the event of a clean closure option

\subsection{SOURCES OF INFORMATION}

Existing information, such as historical documentation, personnel interviews, site process knowledge, site walk-downs, photographs, and previous field screening and analytical results, will be evaluated to determine if it supports the development and evaluation of alternatives. Several types of data will be used to develop corrective action alternatives.

\subsubsection{Qualitative Data}

Qualitative data identify or describe the characteristics or components of the site. The quality assurance/quality control (QA/QC) requirements are the least rigorous for qualitative data. This measurement of quality is typically assigned to historical information and data where QA/QC may be highly variable or not known. Professional judgment is often used to generate qualitative data.

Qualitative data used to support the development of corrective action alternatives are mainly limited to waste records prior to 1988 . However, bounding estimates can be used to adequately account for any uncertainties without adversely affecting the decision-making process. This approach was implemented in the original PA for the Area 5 RWMS, in which bounding assumptions were made regarding the facility performance, and the inventory was evaluated to show compliance with the performance objectives of DOE O 435.1 for a compliance period of 10,000 years. The second addendum to the PA explicitly accounted for uncertainty by employing probabilistic modeling as described in Section 1.3. 


\subsubsection{Semi-quantitative Data}

Semi-quantitative data indirectly measure the quantity or amount of a characteristic or component. Inferences are drawn about the quantity or amount of a characteristic or component because a correlation has been shown to exist between the indirect measurement and the results from a quantitative measurement. The QA/QC requirements on semi-quantitative collection and measurement systems are high but may not be as rigorous as those for quantitative data.

Some semi-quantitative data have been used in various aspects of inventory development. Semi-quantitative data will also be used to estimate costs. Cost models using data from similar sites will be used to develop costs for each corrective action alternative.

\subsubsection{Quantitative Data}

Quantitative data measure the quantity or amount of a characteristic or component. These data require the highest level of QA/QC in collection and measurement systems because the intended use of the data is to resolve primary decisions and/or to verify that closure standards have been met. Laboratory analytical data are generally considered quantitative.

Quantitative measurements have been collected to support the development of the CSM and, during long-term monitoring, to determine whether contaminant migration has occurred. 


\subsection{DEFINE THE BOUNDARIES OF THE STUDY (STEP 4)}

Step 4 of the DQO process defines the target population of interest, specifies the spatial boundaries and time constraints of that population pertinent for decision making, and determines practical constraints on data collection.

\subsection{Population OF INTEREST}

The populations of interest for which corrective actions will be developed include the following six units:

- LLW Unit

- CAU 111

- Asbestiform Unit

- Pit 3 MWDU

- TRU GCD Borehole Unit (CAU 207 [currently in CAU 5000])

- $\quad$ TRU Trench Unit

This includes waste inventory, waste constituents, and design parameters of the disposal cells. The population of interest will also include input parameters needed to develop costs and risks for corrective action alternatives, including identification of offsite disposal capacity, routes of transportation to the disposal capacity, definition of likely receptors along the route to disposal, population of potentially exposed workers, cost data, and the parameters described in the CSM.

\subsection{Time ConstrainTs}

The study data will be evaluated considering the length of time that will be required to develop corrective action alternatives and garner agreement from NDEP on the selection of a correct action alternative. In addition, a further time constraint will be the development of the Corrective Action Decision Document/Corrective Action Plan (CADD/CAP). Furthermore, if classified information must be accessed, additional time may be needed to complete the study.

The schedule will also take into account the time required to complete the closure process and prepare the Closure Report. The certificate of closure for the Pit 3 MWDU is due to NDEP by July 2011; therefore, the Closure Report will be prepared with this due date in mind. 


\subsection{DEVELOP THE ANALYTIC APPROACH (STEP 5)}

Step 5 of the DQO process develops a decision rule statement ("If..., then...") that defines the conditions under which possible alternative actions will be chosen.

\subsection{DECISION RULES}

Decision I:

- If it is determined that closure in place is the most feasible closure option, then a closure design will be developed ensuring that the performance criteria specified in DOE O 435.1 are met. It will be established that these criteria, while designed for radionuclide constituents, are also appropriate for hazardous constituents.

Decision II:

- If it is determined that clean closure is the most feasible closure option, then a closure plan will be prepared outlining the remediation plans that will include the development of an appropriate dose-based remediation standard.

\subsection{ACTION LEVELS}

Action levels for a closure-in-place alternative will be based on the landfill performance standards set forth in the various regulations that cover each of the six areas included in the 92-Acre Area.

The clean-closure alternative will rely upon the preliminary action levels for radiological contaminants. These action levels are based on the National Council on Radiation Protection and Measurements (NCRP)-recommended screening limits for construction, commercial, and industrial land-use scenarios (NCRP, 1999) scaled to $25 \mathrm{mrem} / \mathrm{yr}$ dose constraint (Murphy, 2004) and the generic guidelines for residual concentration of radionuclides in DOE O 5400.5 (DOE, 1993). Remaining radiological contamination will be posted per the NV/YMP RadCon Manual (NNSA/NSO, 2004).

\subsection{MeASUREMENT AND ANALYSIS SENSITIVITY}

Historical monitoring data have been of sufficient sensitivity to measure the worker dose and/or potential contaminant migration for the 92-Acre Area. These data were collected under a published DQO process as provided for in the Routine Radiological Environmental Monitoring Plan (BN, 2003).

To account for uncertainty in inventory development, bounding assumptions were used in the development of the model, as discussed in Section 1.3 of this document. Care has been taken to ensure these assumptions are reasonable, so as not to skew the evaluation of corrective action alternatives. 


\subsection{SPECIFY PERFORMANCE OR ACCEPTANCE CRITERIA (STEP 6)}

Step 6 of the DQO process specifies performance criteria for the decision rules. Setting tolerable limits on decision errors requires the planning team to weigh the relative effects of threats to human health and the environment, expenditure of resources, and the consequences of an incorrect decision. This section provides an assessment of the possible outcomes of DQO decisions and the impact of those outcomes if the decisions are in error.

In general, confidence in DQO decisions will be established qualitatively by the following:

- Developing CSMs

- Testing the validity of the CSMs based on an analysis of historical data

- Evaluating the quality of the data based on data quality indicator parameters

\subsection{DECISION ERRORS}

While additional corrective actions may be developed during the CADD/CAP process, the two bounding alternatives are closure in place and clean closure. A corrective action alternative has not been selected; however, to facilitate discussion of decision errors, closure in place will be defined as the baseline condition.

\subsubsection{False Rejection}

This error would mean deciding that the baseline condition is false when, in fact, it is true. This error means deciding that clean closure is the most advantageous option when closure in place is actually the preferable alternative. The possible consequences of this decision error are increased worker dose during removal, packaging, and transportation of waste; increased short-term risk to the public during transportation of waste; and increased cost. This error will be controlled by having a high degree of confidence in the data inputs such as waste inventory and the CSM. Assumptions that may be required to evaluate this alternative will be bounding, but reasonable enough to ensure the decision process is not adversely affected.

\subsubsection{False Acceptance}

This error would mean deciding that the baseline condition is true when, in fact, it is false. This error means deciding that closure in place is the most advantageous option when clean closure is actually the preferable alternative. The potential consequence is an increased risk to human health and the environment due to leaving the waste in place. This error will be controlled by having a high degree of confidence in the data inputs such as waste inventory and the CSM. Further, since most of these sites are currently controlled for radiological purposes and there is no proximal public receptor, the impact of this error is minimized. 


\subsection{DEVELOP THE PLAN FOR OBTAINING DATA (STEP 7)}

Step 7 of the DQO process provides the general approach for resolving the decisions. The pool of existing data will be used to resolve the decisions outlined above.

\subsection{Process KNOWLEDGe}

The historical operations associated with this site are well documented through multiple historical sources. Much of the operational information is based on semi-quantitative, and in some cases, quantitative data.

\subsection{WASTE INVENTORY RECORDS}

Much of this information has been gathered under compliance assessments of the Area 5 RWMS performed over a 20-year period. The available inventory will be used in the development of corrective action alternatives. Insensitivity of inventory to the results of the facility performance for the 1,000-year post-closure period supports the previous assertion made in Section 1.3 that waste inventory is sufficient to carry out the development of corrective action alternatives.

\subsection{Conceptual Site Model}

A large pool of quantitative data has been collected to accurately describe the CSM, thus providing the support needed to adequately quantify the risks and benefits of each of the proposed corrective action alternatives. 


\subsection{REFERENCES}

Albright, W., S. Tyler, J. Chapman, M. Miller, and R. Estrella, 1994. Area 5 Site Characterization Project Report FY 1994. DOE/NV/10845-T20. Desert Research Institute, Las Vegas, NV.

Allred, D. M., D. M. Beck, and C. D. Jorgensen, 1963. "Biotic Communities of the Nevada Test Site.” Brigham Young University Science Bulletin, Biological Series 2(2), No. 2.

American National Standards Institute, 1987. American National Standard for Nuclear Materials, Unirradiated Plutonium Scrap, Classification. ANSI N 15.10-1987. New York, NY.

Andraski, B. J., 1997. Soil-Water Movement Under Natural-Site and Waste-Site Conditions: A Multiple-Year Field Study in the Mojave Desert, Nevada. Water Resources Research. Vol. 33, No. 8, pp. 1,901-1,916.

ANSI, see American National Standards Institute.

Bechtel Nevada, 2001a. Addendum 1, Performance Assessment for the Area 5 Radioactive Waste Management Site at the Nevada Test Site, Nye County, Nevada: Reevaluation of the Chronic Inadvertent Human Intrusion Scenarios to Resolve the Disposal Authorization Statement Issues. DOE/NV/11718--176-ADD1. Las Vegas, NV.

Bechtel Nevada, 2001b. Composite Analysis for the Area 5 Radioactive Waste Management Site at the Nevada Test Site, Nye County, Nevada. DOE/NV--594. Las Vegas, NV.

Bechtel Nevada, 2001c. Addendum 1: Composite Analysis for the Area 5 Radioactive Waste Management Site at the Nevada Test Site, Nye County, Nevada. DOE/NV--594-ADD1. Las Vegas, NV.

Bechtel Nevada, 2003. Nevada Test Site Routine Radiological Environmental Monitoring Plan. DOE/NV/11718--804. Las Vegas, NV.

Bechtel Nevada, 2005a. Characterization Report: Operational Closure Covers for the Area 5 Radioactive Waste Management Sites at the Nevada Test Site. DOE/NV/11718--758. Las Vegas, NV.

Bechtel Nevada, 2005b. Hydrogeologic Characterization Data for the Area 5 Shallow Soil Trenches, Nevada, Nevada Test Site, Nye County, Nevada. DOE/NV/11718--1060. Las Vegas, NV.

Bechtel Nevada, 2005c. Site Characterization and Monitoring Data for the Area 5 Pilot Wells, Nevada Test Site, Nye County, Nevada. DOE/NV/11718--1067. Las Vegas, NV.

Bechtel Nevada, 2005d. Integrated Closure and Monitoring Plan for the Area 3 and Area 5 Radioactive Waste Management Sites at the Nevada Test Site. DOE/NV/11718--449REV2. Las Vegas, NV.

Bechtel Nevada, 2005e. A Hydrostratigraphic Model and Alternatives for the Groundwater Flow and Contaminant Transport Model of Corrective Action Unit 98: Frenchman Flat, Nye County, Nevada. DOE/NV/11718--1064. Las Vegas, NV. 
Bechtel Nevada, 2005f. Nevada Test Site 2004 Waste Management Monitoring Report, Area 3 and Area 5 Radioactive Waste Management Sites. BN-NTS-05-0025. Las Vegas, NV.

Bechtel Nevada, 2005g. Nevada Test Site 2004 Data Report: Groundwater Monitoring Program, Area 5 Radioactive Waste Management Site. DOE/NV/11718--1015. Las Vegas, NV.

Bechtel Nevada, 2006. Addendum 2 to the Performance Assessment of the Area 5 RWMS at the NTS, Nye County, Nevada Update of the Performance Assessment Methods and Results DOE/NV/11718--176ADD2. Las Vegas, NV.

BN, see Bechtel Nevada.

Blout, D. O., D. P. Hammermeister, K. A. Zukosky, and K. D. Donnelson, 1995. Site Characterization Data from the Area 5 Science Boreholes, Nevada Test Site, Nye County, Nevada. DOE/NV/11432-170. Reynolds Electrical and Engineering Company, Inc. Las Vegas, NV.

Bowen, S. M., D. L. Finnegan, J. L. Thompson, C. M. Miller, P. L. Baca, L. F. Olivas, G. C. Geoffrion, D. K. Smith, W. Goishi, B. E. Esser, J. W. Meadows, N. Namboodiri, and J. F. Wild, 2001. Nevada Test Site Radionuclide Inventory, 1951-1992. LA-13859-MS. Lawrence Livermore National Laboratory. Livermore, CA.

Chapman, J. B., 1995. "Evaporation Calculations at the Area 5 Radioactive Waste Management Site Based on Stable Isotope Data." Letter report to T. Brown, Sandia National Laboratories. Desert Research Institute. Las Vegas, NV.

Chapman, J. B., 1997. "Evaporation Calculations at the Area 3 Waste Disposal Site Based on Stable Isotope Data." Letter report to B. Moore, Waste Management Division, U.S. Department of Energy. Desert Research Institute. Las Vegas, NV.

Chu, M. S. Y., and E. A. Bernard, 1991. Waste Inventory and Preliminary Source Term Model for the Greater Confinement Disposal Site at the Nevada Test Site. SAND91-0170, UC-902. Sandia National Laboratories. Albuquerque, NM.

Cochran, J. R., W. E. Beyeler, D. A. Brosseau, L. H. Brush, T. J. Brown, B. Crowe, S. H. Conrad, P. A. Davis, T. Ehrhorn, T. Feeney, B. Fogleman, D. P. Gallegos, R. Haaker, E. Kalinina, L. L. Price, D. P. Thomas, and S. Wirth, 2001. Compliance Assessment Document for the Transuranic Wastes in the Greater Confinement Disposal Boreholes at the Nevada Test Site. Sandia National Laboratories, SAND2001-2977. Albuquerque, NM.

Colarusso, A., B. Crowe, and J. R. Cochran, 2003. "Completion of the Transuranic Greater Confinement Disposal Borehole Performance Assessment for the Nevada Test Site." In: Proceedings of the Waste Management '03 Conference. Tucson, AZ.

Denton, R. C., M. R. Dolenc, and R. B. Hudson, 2008. An Evaluation of Historical Nevada Test Site Waste Records and an Interpretation of the Waste Volume. Las Vegas, NV.

Desotell, L. T., D. B., Hudson, V. Yucel, and J. T. Carilli, 2006. "Use of Long-Term Lysimeter Data in Support of Shallow Land Waste Disposal Cover Design." In: Proceedings of the Waste Management '06 Conference. Tucson, AZ. 
Dickman, P. T., 1989. Greater Confinement Disposal Test at the Nevada Test Site, Final Technology Report, Rev. 1. Prepared by Science Applications International Corporation for Reynolds Electrical and Engineering Company, Inc.

DOE, see U.S. Department of Energy.

EPA, see U.S. Environmental Protection Agency.

Fiore, J., and R. Berube, 2002. Letter to Carl Gertz (DOE/NV) Subject: Compliance Assessment for the Transuranic Wastes in the Greater Confinement Disposal Boreholes at the Nevada Test Site. February 5, 2002.

Foxx, T. S., G. D. Tierney, and J. M. Williams, 1984a. Rooting Depths of Plants on Low-Level Waste Sites. LA-10253-MS. Los Alamos National Laboratory. Los Alamos, NM.

Foxx, T. S., G. D. Tierney, and J. M. Williams, 1984b. Rooting Depths of Plants as Related to Biological and Environmental Factors. LA-10254-MS. Los Alamos National Laboratory. Los Alamos, NM.

Hansen, D. J., and W. K. Ostler, 2003. Rooting Characteristics of Vegetation Near Radioactive Waste Management Sites 3 and 5 at the Nevada Test Site. DOE/NV/11718--595. Bechtel Nevada. Las Vegas, NV.

Hunter, R. B., and P. A. Medica, 1989. Status of the Flora and Fauna on the Nevada Test Site: Results of Continuing Basic Environmental Research, January through December 1987. DOE/NV/10630-2. Reynolds Electrical and Engineering Company, Inc.

Laczniak, R. J., J. C. Cole, D. A. Sawyer, and D. A. Trudeau, 1996. Summary of Hydrogeologic Controls on Ground-Water Flow at the Nevada Test Site, Nye County, Nevada. U.S. Geological Survey Water-Resources Investigations Report 96-4109.

Murphy, T., 2004. Nevada Division of Environmental Protection, Letter to R. M. Bangerter, Jr. (NNSA/NSO) entitled, "Review of Industrial Sites Project Document 'Guidance for Calculating Industrial Sites Project Remediation Goals for Radionuclides in Soil Using the Residual Radiation (RESRAD) Computer Code."” November 19, 2004. Las Vegas, NV.

National Council on Radiation Protection and Measurements, 1999. Recommended Screening Limits for Contaminated Surface Soil and Review of Factors Relevant to Site-Specific Studies. NCRP Report No. 129. Washington, D.C.

NCRP, see National Council on Radiation Protection and Measurements.

O'Farrell, T. P., and L. A. Emery, 1976. Ecology of the Nevada Test Site: A Narrative Summary and Annotated Bibliography. NVO-167. National Technical Information Service Publication. Springfield, VA.

O’Leary, D. W., 1996. "Tectonic Significance of the Rock Valley Fault Zone, Nevada Test Site." In: Whitney, J. W. (ed.) Seismotectonic Framework and Characterization of Faulting at Yucca Mountain, Nevada. U.S. Geological Survey. Denver, CO.

Ostler, W. K., D. J. Hansen, D. C. Anderson, and D. B. Hall, 2000. Classification of Vegetation on the Nevada Test Site. DOE/NV/11718--477. Bechtel Nevada. Las Vegas, NV.

REECo, see Reynolds Electrical and Engineering Company, Inc. 
Reynolds Electrical and Engineering Company, Inc., 1993a. Hydrogeologic Data for Existing Excavations at the Area 5 Radioactive Waste Management Site, Nevada Test Site, Nye County, Nevada. DOE/NV/11432-40.

Reynolds Electrical and Engineering Company, Inc., 1993b. Hydrogeologic Data for Science Trench Boreholes at the Area 5 Radioactive Waste Management Site, Nevada Test Site, Nye County, Nevada. DE-AC08-94-NV 11432 UC 721.

Schmeltzer, J. S., J. J. Miller, and D. L. Gustafson, 1993. Flood Assessment at the Area 5 Radioactive Waste Management Site and the Proposed Hazardous Waste Storage Unit, DOE, Nevada Test Site, Nye County, Nevada. Raytheon Services Nevada. Las Vegas, NV.

Shott, G. J., L. E. Barker, S. E. Rawlinson, M. J. Sully, and B. A. Moore, 1998. Performance Assessment of the Area 5 Radioactive Waste Management Site at the Nevada Test Site, Nye County, Nevada, Revision 2.1. DOE/NV/11718--176. Bechtel Nevada. Las Vegas, NV.

Shott, G. J., V. Yucel, and L. Desotell, 2008. Special Analysis of Transuranic Waste in Trench T04C at the Area 5 Radioactive Waste Management Site, Nevada Test Site, Nye County, Nevada, Revision 1.0. DOE/NV/25946--470. Las Vegas, NV.

Snyder, K. E., R. D. Van Remortel, D. L. Gustafson, H. E. Huckins-Gang, J. J. Miller, S. E. Rawlinson, and S. M. Parsons, 1995. Surficial Geology and Landscape Development in Northern Frenchman Flat, Area 5 Radioactive Waste Management Site, Nevada Test Site. Interim Summary and Soil Data Report. Raytheon Services Nevada. Las Vegas, NV.

Tyler, S. W., J. B. Chapman, S. H. Conrad, D. P. Hammermeister, D. O. Blout, J. J. Miller, M. J. Sully, and J. M. Ginanni, 1996. "Soil-Water Flux in the Southern Great Basin, United States: Temporal and Spatial Variations over the Last 120,000 Years." Water Resources Research. Vol. 32, No. 6, pp. 1,481-1,500.

Tyler, S. W., J. Chapman, and C. Cooper, 1999. Estimates of Evaporation at the Area 5 Radioactive Waste Management Site, Nevada Test Site: Evaluation of Estimates Based on Stable Isotopes and Comparisons to Other Methods. DOE/NV/11508--46. Desert Research Institute, Publication No. 45169. Las Vegas, NV.

U.S. Department of Energy, 1993. DOE O 5400.5, "Radiation Protection of the Public and the Environment." Washington, D.C.

U.S. Department of Energy, 1999a. DOE O 435.1, "Radioactive Waste Management." Washington, D.C.

U.S. Department of Energy, 1999b. DOE M 435.1-1, "Radioactive Waste Management Manual." Washington, D.C.

U.S. Department of Energy, 2004. DOE Standard Guide of Good Practices for Occupational Radiological Protection in Uranium Facilities. DOE-STD-1136-2004. Washington, D.C.

U.S. Department of Energy, National Nuclear Security Administration Nevada Site Office, 2004. NV/YMP RadCon Manual. DOE/NV/11718-079 Rev. 5. Las Vegas, NV. 
U.S. Environmental Protection Agency, 2006. Guidance on Systematic Planning Using the Data Quality Objectives Process. EPA QA/G-4. Washington, D.C.

Walvoord, M.A., F. M. Phillips, S. W. Tyler, and P. C. Hartsough, 2002a. "Deep Arid System Hydrodynamics 2. Application to Paleohydrologic Reconstruction Using Vadose Zone Profiles from the Northern Mojave Desert." Water Resources Research. Vol. 38, No. 12, pp. 1,291.

Walvoord, M. A., M. A. Plummer, F. M. Phillips, and A. V. Wolfsberg, 2002b. "Deep Arid System Hydrodynamics 1. Equilibrium States and Response Times in Thick Desert Vadose Zones." Water Resources Research. Vol. 38, No. 12, pp. 1,308.

Wolfsberg, A., and P. Stauffer, 2003. Vadose-zone Fluid and Solute Flux: Advection and Diffusion at the Area 5 Radioactive Waste Management Site. LA-UR-03-4819. Los Alamos National Laboratory. Los Alamos, NM. 
92-Acre Area and CAU 111 CADD/CAP Section: Appendix B

Revision: 1

Date: November 2010

\section{APPENDiX B}

\section{Cost Estimates}


92-Acre Area and CAU $111 \mathrm{CADD} / \mathrm{CAP}$

Section: Appendix B

Revision: 1

Date: November 2010

THIS PAGE INTENTIONALLY LEFT BLANK 
SUBJECT: CADD Alternative Cost Estimates for the 92-Acre Area and CAU 111

ESTIMATOR: Thomas Thiele REF \#:

TYPE OF ESTIMATE:

$\begin{array}{ll}\mathbf{X} & \begin{array}{l}\text { ORDER OF MAGNITUDE } \\ \text { PRELIMINARY / PLANNING / STUDY }\end{array} \\ \text { CONCEPTUAL / BUDGET } & \\ \text { TITLE I } & -\begin{array}{l}\text { TITLE II } \\ \text { WORK ORDER } \\ \text { COMPARATIVE } \\ \text { OTHER }\end{array}\end{array}$

TYPE OF WORK:

\begin{tabular}{l} 
NON-MANUAL ONLY \\
\hline $\mathbf{X}$ MANUAL ONLY \\
\hline \\
\hline
\end{tabular}

PROJECT WORK SCOPE IS EXPECTED TO BE PERFORMED BY:

DOE PRIME (LUMP SUM)

CONSTRUCTION $\overline{\mathbf{X}}$

MAINTENANCE
SUBCONTRACT

GPP

OTHER

\section{STATEMENT OF WORK}

This estimate has been prepared to provide remedial alternative costs for the closure of the 92-Acre Area and Corrective Action Unit (CAU) 111. CAU 111 is an environmental restoration site listed in the Federal Facility Agreement and Consent Order ; however, the entire 92-Acre Area will be closed under this plan. Three alternatives have been evaluated for closure of the site: Alternative 1, No Further Action; Alternative 3, Closure in Place with Administrative Controls; and Alternative 4, Closure in Place with Administrative Controls with Removal of TRU Waste from Trench T04A. Alternative 2, Clean Closure, was not evaluated for closure of the site. This estimate will be used to identify the most cost effective alternative for closure of the site while remaining protective of human health and the environment. Cost for project management, plan preparation, project support, and/or other activities are not included herein.

\section{SCOPE:}

Provide site closure using the following alternative:

Alternative 1, No Further Action

\section{BASIS:}

This site consists of the 92-Acre Area, the southeast quadrant of the Radioactive Waste Management Site, located in Area 5 of the NTS. The 92-Acre Area includes CAU 111, Area 5 WMD Retired Mixed Waste Pits. This alternative includes continuing the current monitoring activities conducted at the 92-Acre Area. Monitoring consists of quarterly direct radiation measurements, air samples for tritium every 2 weeks, monthly air samples for particulates, annual radon flux measurements, groundwater samples every 6 months, meteorology monitoring (precipitation, temperature, humidity, wind speed/direction, and barometric pressure), quarterly moisture probe measurements, quarterly lysimeter measurements, annual soil gas monitoring, and biota samples every 2 years.

\section{ALTERNATIVE SPECIFIC BASIS OF ESTIMATE/ASSUMPTIONS}

Alternative 1, No Further Action

- Continuing the following monitoring activities:

- Quarterly direct radiation measurements

- Air samples for tritium every 2 weeks and monthly air samples for particulates

- Annual radon flux measurements

- Groundwater samples every 6 months

- Meteorology monitoring (precipitation, temperature, humidity, wind speed/direction, and barometric pressure)

- Quarterly moisture probe and lysimeter measurements

- Annual soil gas monitoring

- Biota samples every 2 years 
ASSUMPTIONS:

- Equipment will remain operational to support the planned/scheduled completion of each CADD alternative.

- Work to be performed during a "normal" workday (no provision for overtime has been provided). Shifts are based on 10-hour days,

4 days per week.

- This estimate does not include the efficiencies which may be realized if work for similar activities at similar sites can be completed concurrently.

- This estimate does not include costs for preparation of required project plans, permits, reports, mobilization and demobilization, site preparations, or project management.

\section{ESCALATION:}

No escalation factors have been applied. All costs are in FY09 Rev. 1 dollars.

\section{CONTINGENCY:}

Contingency costs are not included in this estimate.

\section{RATES:}

Rates are based on FY09 final rates (Rev. 1) effective 10/01/08 and were applied using the FY09 cost model.

\section{COST ALTERNATIVES SUMMARY:}

Alternative 1, No Futher Action

1. Continuing the current monitoring activities

Monitoring Costs: $\$ 700,000 /$ year

\section{REVIEW/CONCURRENCE:}

/s/: A. L. Primrose

Project Manager

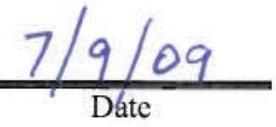

Date

/s/: Thomas A. Thiele

Estimator

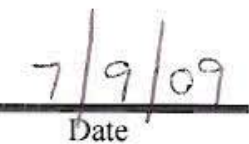

/s/: JAC, Teri Browdy

Project Controls

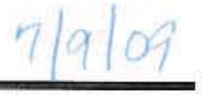

Date 
SUBJECT: CADD Alternative Cost Estimates for the 92-Acre Area and CAU 111

ESTIMATOR: Thomas Thiele REF \#:

\begin{tabular}{|c|c|c|c|}
\hline \multicolumn{3}{|c|}{$\begin{array}{l}\text { TYPE OF ESTIMATE: } \\
\end{array}$} & \multirow{2}{*}{$\begin{array}{c}\text { TYPE OF WORK: } \\
\text { NON-MANUAL ONLY }\end{array}$} \\
\hline $\mathbf{x}$ & ORDER OF MAGNITUDE & TITLE II & \\
\hline & PRELIMINARY / PLANNING / STUDY & WORK ORDER & MANUAL ONLY \\
\hline & CONCEPTUAL / BUDGET & COMPARATIVE & $\overline{\mathbf{X}}$ MANUAL \& NON-MANUAL \\
\hline
\end{tabular}

PROJECT WORK SCOPE IS EXPECTED TO BE PERFORMED BY:

DOE PRIME (LUMP SUM)

MAINTENANCE

SUBCONTRACT

GPP

OTHER

\section{STATEMENT OF WORK}

This estimate has been prepared to provide remedial alternative costs for the closure of the 92-Acre Area and Corrective Action Unit (CAU) 111. CAU 111 is an environmental restoration site listed in the Federal Facility Agreement and Consent Order; however, the entire 92-Acre Area will be closed under this plan. Three alternatives have been evaluated for closure of the site: Alternative 1, No Further Action; Alternative 3, Closure in Place with Administrative Controls; and Alternative 4, Closure in Place with Administrative Controls with Removal of TRU Waste from Trench T04A. Alternative 2, Clean Closure, was not evaluated for closure of the site. This estimate will be used to identify the most cost effective alternative for closure of the site while remaining protective of human health and the environment. Cost for project management, plan preparation, project support, and/or other activities are not included herein.

\section{SCOPE:}

Provide site closure using the following alternative:

Alternative 3, Closure in Place with Administrative Controls

\section{BASIS:}

This site consists of the 92-Acre Area, the southeast quadrant of the Radioactive Waste Management Site, located in Area 5 of the NTS. The 92-Acre Area includes CAU 111, Area 5 WMD Retired Mixed Waste Pits. This alternative includes construction of a 2.5m-thick engineered evapotranspiration cover over the 92-Acre Area. With the exception of three active pits, all trenches and pits in the 92-Acre Area have current operational covers approximately $2.4 \mathrm{~m}$ thick; therefore, construction of the cover over these units will consist of augmenting the current operational covers to the final thickness, grade, and slope required by the final engineering design. After cover construction activities are complete, the cover will be seeded with a mixture of shallow rooting native plants. Use restriction warning signs and concrete monuments will be installed. Subsidence survey monuments will also be installed.

\section{ALTERNATIVE SPECIFIC BASIS OF ESTIMATE/ASSUMPTIONS}

\section{Alternative 3, Closure in Place with Administrative Controls}

- Constructing an engineered evapotranspiration cover over the 92-Acre Area

- Installing use restriction warning signs, concrete monuments, and subsidence survey monuments 


\section{ASSUMPTIONS:}

- Equipment will remain operational to support the planned/scheduled completion of each CADD alternative.

- Work to be performed during a "normal" workday (no provision for overtime has been provided). Shifts are based on 10-hour days, 4 days per week.

- This estimate does not include the efficiencies which may be realized if work for similar activities at similar sites can be completed concurrently.

- This estimate does not include costs for preparation of required project plans, permits, reports, mobilization and demobilization, site preparations, or project management.

\section{ESCALATION:}

No escalation factors have been applied. All costs are in FY09 Rev. 1 dollars.

\section{CONTINGENCY:}

Contingency costs are not included in this estimate.

\section{RATES:}

Rates are based on FY09 final rates (Rev. 1) effective 10/01/08 and were applied using the FY09 cost model.

\section{COST ALTERNATIVES SUMMARY:}

\section{Alternative 3, Closure in Place with Administrative Controls}

1. Constructing an engineered evapotranspiration cover over the 92-Acre Area

2. Installing use restriction warning signs, concrete monuments, and subsidence survey monuments

Construction Costs: $\$ 2,640,000$

Monitoring Costs: $\$ 660,000 /$ year

\section{REVIEW/CONCURRENCE:}

/s/: A. L. Primrose

Project Manager

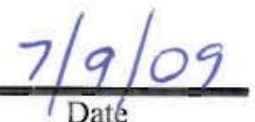

Daté

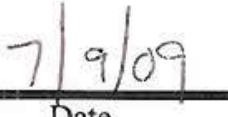

Date

\section{/s/: JAC, Teri Browdy}


SUBJECT: CADD Alternative Cost Estimates for the 92-Acre Area and CAU 111

ESTIMATOR: Thomas Thiele REF \#:

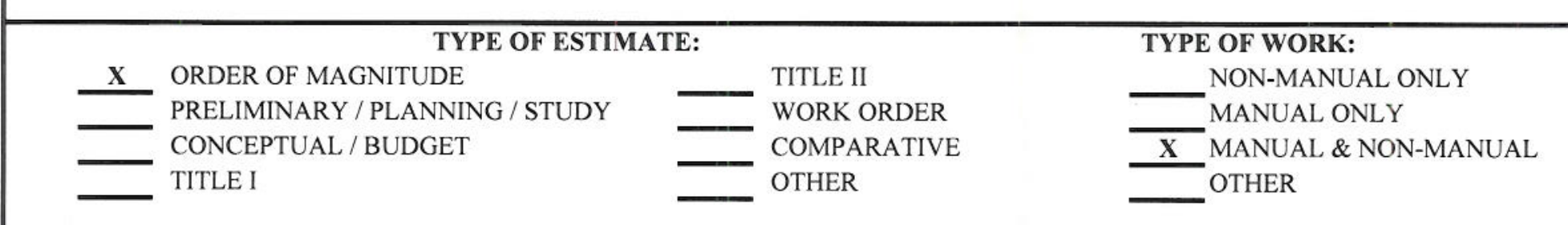

PROJECT WORK SCOPE IS EXPECTED TO BE PERFORMED BY:

DOE PRIME (LUMP SUM)

MANSTRUCTION $\overline{\mathbf{x}}$

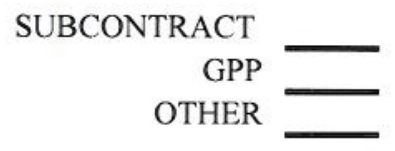

\section{STATEMENT OF WORK}

This estimate has been prepared to provide remedial alternative costs for the closure of the 92-Acre Area and Corrective Action Unit (CAU) 111. CAU 111 is an environmental restoration site listed in the Federal Facility Agreement and Consent Order; however, the entire 92-Acre Area will be closed under this plan. Three alternatives have been evaluated for closure of the site: Alternative 1, No Further Action; Alternative 3, Closure in Place with Administrative Controls; and Alternative 4, Closure in Place with Administrative Controls with Removal of TRU Waste from Trench T04A. Alternative 2, Clean Closure, was not evaluated for closure of the site. This estimate will be used to identify the most cost effective alternative for closure of the site while remaining protective of human health and the environment. Cost for project management, plan preparation, project support, and/or other activities are not included herein.

\section{SCOPE:}

Provide site closure using the following alternative:

Alternative 4, Closure in Place with Administrative Controls with Removal of TRU Waste from Trench T04A

\section{BASIS:}

This site consists of the 92-Acre Area, the southeast quadrant of the Radioactive Waste Management Site, located in Area 5 of the NTS. The 92-Acre Area includes CAU 111, Area 5 WMD Retired Mixed Waste Pits. This alternative includes excavation and disposal of TRU waste that was inadvertently disposed in trench T04A in addition to construction of a 2.5 -m-thick engineered evapotranspiration cover over the 92-Acre Area, as described in Alternative III, Closure in Place with Administrative Controls.

\section{ALTERNATIVE SPECIFIC BASIS OF ESTIMATE/ASSUMPTIONS}

Alternative 4, Closure in Place with Administrative Controls with Removal of TRU Waste from Trench T04A

- Excavating and disposing TRU waste from trench T04A

- Constructing an engineered evapotranspiration cover over the 92-Acre Area

- Installing use restriction warning signs, concrete monuments, and subsidence survey monuments 


\section{ASSUMPTIONS:}

- Equipment will remain operational to support the planned/scheduled completion of each CADD alternative.

- Work to be performed during a "normal" workday (no provision for overtime has been provided). Shifts are based on 10-hour days,

4 days per week.

- This estimate does not include the efficiencies which may be realized if work for similar activities at similar sites can be completed concurrently.

- This estimate does not include costs for preparation of required project plans, permits, reports, mobilization and demobilization, site preparations, or project management.

\section{ESCALATION:}

No escalation factors have been applied. All costs are in FY09 Rev. 1 dollars.

\section{CONTINGENCY:}

Contingency costs are not included in this estimate.

\section{$\underline{\text { RATES: }}$}

Rates are based on FY09 final rates (Rev. 1) effective 10/01/08 and were applied using the FY09 cost model.

\section{COST ALTERNATIVES SUMMARY:}

Alternative 4, Closure in Place with Administrative Controls with Removal of TRU Waste from Trench T04A

1. Excavating and disposing TRU waste from trench T04A

2. Constructing an engineered evapotranspiration cover over the 92-Acre Area

3. Installing use restriction warning signs, concrete monuments, and subsidence survey monuments

Construction Costs: $\$ 118,640,000$

Monitoring Costs: $\$ 660,000 /$ year

\section{REVIEW/CONCURRENCE:}

/s/: A. L. Primrose

Project Manager

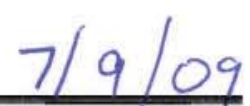

Date

\section{/s/: Thomas A. Thiele}

Estimator

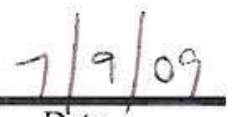

Date

\section{/s/: JAC, Teri Browdy}

Project Controls

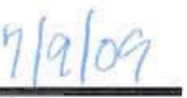

Date 
92-Acre Area and CAU 111 CADD/CAP Section: Appendix C

Revision: 1

Date: November 2010

\section{APPENDiX C}

\section{ENGINEERING SPECIFICATION AND DRAWINGS}


92-Acre Area and CAU $111 \mathrm{CADD} / \mathrm{CAP}$ Section: Appendix C

Revision: 1

Date: November 2010

THIS PAGE INTENTIONALLY LEFT BLANK 


\title{
NEVADA NATIONAL SECURITY SITE
}

\section{Acre Grading and Drainage}

CONSTRUCTION SPECIFICATION

\author{
Document No. 10088-SPC-G01
}

Revision 0

\section{QG-3}

/s/: Shannon Wright Is/: James Walker

Preparer:

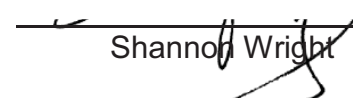
Date: $10 / 6 / 10$ Checker

Project Engineer: $\frac{\text { /s/: Janet Goodrich }}{\bigcup \text { Janet Goodrich }}$ Date: $10 / 6 / 10$

Approver: $\frac{\text { /s/: Jerry D. Freter }}{\text { Jerry D. Freter }}$ Date: $10 / 6 / 10$ 
This page intentionally left blank. 


\section{TABLE OF CONTENTS}

\section{Specification}

$\underline{\text { Section No. } \quad \underline{\text { Rev }} \text { Title }}$

\section{Division 01 - General Requirements}

$015713 \quad 0 \quad$ Temporary Erosion and Sediment Control

Division 31 - Earthwork

311000

$0 \quad$ Site Clearing

$312000 \quad 0 \quad$ Earthwork

$312316 \quad 0 \quad$ Excavation

Division 32 - Exterior Improvements

329301

$0 \quad$ Seeding 
This page intentionally left blank. 


\section{SECTION 015713 \\ TEMPORARY EROSION AND SEDIMENT CONTROL}

\section{PART 1 GENERAL}

\subsection{WORK OF THIS SECTION}

A. This section covers work necessary for stabilization of soil to prevent erosion after construction and land disturbing activities, and prior to seeding of the final cover. The work shall include the furnishing of all labor, materials, tools, and equipment to perform the work and services necessary as herein specified and as indicated on the Drawings. This shall include installation and maintenance of temporary soil erosion and sediment control measures during the interim period between completion of earthworks activities and the initiation of seeding over the final cover.

B. The minimum areas requiring soil erosion and sediment control measures are the final cover areas and borrow area. The right is reserved to modify the use, location, and quantities of soil erosion and sediment control measures based on construction activities and as directed by Engineer.

\subsection{ACRONYMNS, ABBREVIATIONS, AND DEFINITIONS}

A. The following is a list of acronyms which may be included in this section:

1. ANSI

2. NSF

3. $\mathrm{PM}_{10}$
American National Standards Institute

National Sanitation Foundation

Particulate matter with aerodynamic diameter of 10 micrometers

\subsection{REFERENCE STANDARDS}

A. Codes and standards referenced in this specification are as follows:

1. Nevada Division of Environmental Protection, Nevada Contractors Field Guide for Construction Site Best Management Practices

\subsection{GENERAL}

A. All activities shall conform to the Nevada Contractors Field Guide for Construction Site Best Management Practices.

B. Soil erosion stabilization and sedimentation control consist of the following elements: 
1. Maintenance of existing permanent or temporary storm drainage systems, as necessary.

2. Construction of new permanent and temporary storm drainage systems, as necessary.

3. Application of soil binders in areas as specified hereinafter.

C. Sediment transport and erosion from working stockpiles shall be controlled and restricted from moving beyond the immediate stockpile area by construction of temporary toe-of-slope ditches as necessary. These temporary facilities shall be kept in operational condition by regular cleaning, regrading, and maintenance.

D. Unpaved earth drainage ditches shall be regraded as needed to maintain original grade and remove sediment buildup. If a ditch becomes difficult to maintain, install erosion control devices such as check dams, temporary paving, or silt fences in accordance with the Nevada Contractors Field Guide for Construction Site Best Management Practices and as directed by the Engineer.

\subsection{SUBMITTALS}

A. The following information shall be provided:

1. Manufacturer's standard literature for soil binder.

2. Manufacturer's installation recommendations.

3. Manufacturer's Material Safety Data Sheets

4. Applicator qualifications.

\section{PART 2 PRODUCTS}

2.01 SOIL BINDER

A. Petroleum based products, pine tar resins, magnesium chlorides, calcium chlorides, and lignin sulfonates are not acceptable.

B. Product shall be an acrylic, acrylate, and acetate liquid polymer consisting of the following properties in its undiluted state as it is to be delivered to the job site:

1. Composition: Acrylic, Acrylates, and Acetate Liquid Polymer

2. Appearance: Milky White Liquid

3. Odor: Characteristic Acrylic Odor

4. Specific Gravity: 1.01-1.15

5. Density: $8.4-9.5 \mathrm{lbs} / \mathrm{gal}$

6. $\mathrm{pH}: 4.0-9.5$

7. Solubility in Water: Dilutable

8. Solids: Minimum of $40 \%$ 
C. Soil binder product shall be Soil-Sement or approved equal.

D. A Certificate of Compliance shall be submitted to the Engineer for the soil binder product brought to the job site.

\section{PART 3 EXECUTION}

\subsection{PROTECTION OF AREAS AND SPACES}

A. Prior to product application, mask or otherwise protect buildings, concrete, roads, sidewalks, etc.

B. Care will be taken to avoid excess over spray that may affect any adjacent areas.

\subsection{DILUTION OF SOIL BINDER}

A. As required by the manufacturer, the soil binder product shall be diluted with potable water to a ratio in accordance with the manufacturer's recommendations and as approved by the Engineer prior to the application.

\subsection{SYSTEM REQUIREMENTS}

A. Prepare areas for soil binder application as indicated. The application process shall result in a uniformly treated mixture that contains the required amount of soil binder product, as recommended by the manufacturer or as approved by the Engineer. The total application rate to stabilize the surface of the final cover shall be per manufacturer's recommendation.

B. The soil binder product shall be applied to all final cover areas within 7 calendar days of Engineer acceptance of final grades. The soil binder application shall provide $100 \%$ control efficiency of $\mathrm{PM}_{10}$, and control erosion for a minimum of 6 months from date of application. Additional applications may be required, and will be applied within two weeks from a performance failure.

\subsection{SPECIAL REQUIREMENTS}

A. Curing: No equipment or traffic will be permitted on the stabilized area for 48 hours unless approved by the product Manufacturer's representative.

B. No vehicular traffic shall be allowed to drive over completed final surfaces following completion of earthworks. Placement of soil binder shall be through use of hoses, spray booms, or other methods as approved by the Engineer. 


\subsection{DUST CONTROL}

A. During construction, control the dust using water-based application. Chemical-based application for dust control will not be allowed until earthworks activities are complete.

END OF SECTION 


\section{SECTION 311000 SITE CLEARING}

\section{PART 1 GENERAL}

\subsection{WORK OF THIS SECTION}

A. This section covers work necessary to clear the construction area of interfering or objectionable material, vegetation, and other organic matter prior to the start of any earthworks.

\subsection{DEFINITIONS}

A. Interfering or Objectionable Material: Trash, rubbish, and junk.

B. Clearing: Removal of interfering or objectionable material lying on or protruding above ground surface.

C. Grubbing: Removal of vegetation and other organic matter including stumps, buried logs, and roots greater than 2-inch caliper to a depth of 6 inches below subgrade.

D. Project Limits: Areas, as shown or specified, within which Work is to be performed.

1.03 SCHEDULING AND SEQUENCING

A. Prepare Site immediately prior to placement of soil cover.

\section{PART 2 PRODUCTS (NOT USED)}

\section{PART 3 EXECUTION}

3.01 GENERAL

A. Clear areas actually needed for waste disposal, borrow, or Site improvements within limits shown or specified.

B. Do not injure or deface vegetation that is not designated for removal. 


\section{$3.02 \quad$ LIMITS}

A. As follows, but not to extend beyond Project limits.

1. Excavation 5 feet beyond top of cut slopes.

2. Fill:

a. Clearing and Grubbing: 5 feet beyond toe of permanent fill.

3. Waste Disposal:

a. Clearing and Grubbing: 5 feet beyond perimeter.

B. Remove rubbish, trash, and junk from entire area within Project limits.

\subsection{CLEARING}

A. Clear areas within limits shown or specified.

B. Cut off shrubs, brush, weeds, and grasses to within 2 inches of ground surface.

3.04 DISPOSAL

A. Clearing and Grubbing Debris:

1. Dispose of debris offsite.

2. Debris may be buried in designated onsite disposal areas at the direction of the Operator. In lieu of onsite burial, dispose of debris offsite.

3. Burning of debris onsite will not be allowed.

\section{END OF SECTION}




\section{SECTION 312000 EARTHWORK}

\section{PART 1 GENERAL}

\subsection{DESCRIPTION OF WORK}

A. This Section covers all grading and backfill associated with construction of the 92-Acre Grading and Drainage project.

B. Construct the ET final cover over all areas within the ET final cover and grading limits as shown on the Drawings.

1.02 ACRONYMNS, ABBREVIATIONS, AND DEFINITIONS

A. The following is a list of acronyms which may be included in this section:

1. ASTM

2. CQA

3. ET
American Society for Testing and Materials Construction Quality Assurance evapotranspiration

\subsection{REFERENCE STANDARDS}

A. Codes and standards referenced in this specification are as follows:

1. ASTM International (ASTM):

a. D698, Standard Test Methods for Laboratory Compaction

Characteristics of Soil Using Standard Effort $\left(600 \mathrm{kN}-\mathrm{m} / \mathrm{m}^{3}\right)$

b. D1556, Standard Test Method for Density and Unit Weight of Soil in Place by the Sand-Cone Method

c. D2216, Standard Test Methods for Laboratory Determination of Water (Moisture) Content of Soil and Rock by Mass

d. D2487, Standard Practice for Classification of Soils for Engineering Purposes (Unified Soil Classification System)

e. D2488, Standard Practice for Description and Identification of Soils (Visual-Manual Procedure)

f. D6938, Standard Test Method for In-Place Density and Water Content of Soil and Soil-Aggregate by Nuclear Methods (Shallow Depth)

2. Uniform Standard Specifications for Public Works Construction OffSite Improvements

\subsection{DEFINITIONS}

A. Borrow Material: Material from required excavations or from designated borrow areas on or near Site. 
B. Completed Course: A course or layer that is ready for next layer or next phase of Work.

C. Construction Quality Assurance (CQA) Engineer: Engineer providing independent oversight and responsible for implementing the CQA Plan. Independent is defined as an organization that operates separately from the Construction Contractor and the Operating Contractor.

D. Engineer: Design engineer of record providing submittal review, design clarifications, and other services during construction.

E. Imported Material: Materials obtained from Contractor-procured sources offsite, suitable for specified use.

F. Lift: Loose (uncompacted) layer of material.

G. Optimum Moisture Content:

1. Determined in accordance with ASTM Standard specified for relative compaction to determine maximum dry density for relative compaction.

2. Determine field moisture content on basis of fraction passing $3 / 4$ inch sieve.

H. Owner: Party that retains ownership of the cover area, and is responsible for construction and maintenance of the final cover.

I. Prepared Ground Surface: Ground surface after completion of required demolition, clearing and stripping of surface soils, excavation to grade, and subgrade preparation.

J. Relative Compaction: Ratio, in percent, of as-compacted field dry density to laboratory maximum dry density as determined in accordance with ASTM D698.

K. Subgrade: Layer of existing soil after completion of clearing and grubbing prior to placement of fill.

L. Well-Graded:

1. A mixture of particle sizes with no specific concentration or lack thereof of one or more sizes.

2. Used to define material type that, when compacted, produces a strong and relatively incompressible soil mass free from detrimental voids. 


\subsection{SUBMITTALS}

A. Provide the Following Submittals:

1. List of proposed equipment to be used in performance of construction work including descriptive data prior to commencing with construction activities.

\subsection{QUALITY ASSURANCE AND QUALITY CONTROL}

A. Provide adequate survey control to avoid overexcavation.

B. Notify Engineer when:

1. Subgrade is ready for fill placement and whenever fill placement operations are resumed after a period of inactivity.

2. Soft or loose subgrade materials are encountered.

3. Fill material appears to deviate from specifications.

C. Work will be observed as it progresses and quality control test data will be reviewed by the CQA Engineer. Independent testing or analysis may be done by the CQA Engineer as deemed necessary to verify accuracy of results.

1. Prior to performing any seeding, submit to the Owner a typed report, prepared and sealed by a Nevada-registered professional Civil or Geotechnical Engineer, summarizing all tests performed and certifying that all earthwork as being constructed in accordance with the Drawings and these Specifications.

D. An independent third party, whether a separate entity of the Owner or an outside consultant, will be required to determine the in-place density and moisture content of the subgrade and compacted fill by combination of two or more of the following methods: ASTM D1556, D2216, or D6938. These test results, certified by the CQA Engineer and reviewed by Engineer, shall indicate that the actual soil compaction found meets these Specifications. Testing will occur as the work progresses and compliance with the Specifications is required prior to final acceptance of the Work.

\section{PART 2 PRODUCTS}

2.01 WATER

A. Arrangements shall be made to supply all water needs associated with the Work of this Section. 
A. General: Provide borrow soil materials when sufficient satisfactory soil materials are not available from excavations.

B. Satisfactory Soils: ASTM D2487, Soil Classification Groups GM, GC, SW, $\mathrm{SP}, \mathrm{SC}, \mathrm{SM}, \mathrm{ML}$, and MH, or a combination of these groups; free of rock or gravel larger than 9 in. in any dimension, debris, waste, frozen materials, vegetation, and other deleterious matter. Some cobble may require removal at the discretion of the Engineer.

C. Unsatisfactory Soils: Soil Classification Groups GW, GP, CL, OL, CH, OH, and PT according to ASTM D2487, or a combination of these groups.

\subsection{MATERIAL FOR RIP RAP}

A. Gravel:

1. Well-graded rounded or subrounded rock.

2. Uniformly graded from course to fine.

3. Free from excessive dirt and other organic material.

4. Maximum 2-inch particle size.

B. Rock: Cobble sufficiently durable to ensure permanence in the structure and the environment which it is to be used. Rock shall be free from cracks, seams, and other defects that would increase the risk of deterioration from natural causes. The size of the rock shall be such that no individual rock exceeds a weight of 150 pounds and that no more than 10 percent of the mixture, by weight, consists of rock weighing 2 pounds or less each. The inclusion of more than trace 1 percent quantities of dirt, sand, clay and rock fines will not be permitted.

C. Geotextile: Geotextile shall be 6 ounce per square yard non-woven polypropylene, stable fiber, needlepunched. The use of geotextile in place of granular bedding will be restricted to slopes no steeper than $2.5 \mathrm{H}: 1 \mathrm{~V}$. A 6inch layer of fine aggregate per Uniform Standard Specifications for Public Works Construction Off-Site Improvements Section 706.03.03 to be placed on top of the geotextile to act as a cushion when placing the rock. Tears in the fabric greatly reduce its effectiveness so that direct dumping of rock on the geotextile is not allowed and due care must be exercised during construction.

\section{PART 3 EXECUTION}

\subsection{GENERAL}

A. Perform grading and fill to the lines, grades and dimensions shown on the Drawings and as needed to accomplish Work. 
B. Keep fill placement surfaces free of water, debris, and foreign material during placement and compaction of fill materials.

C. Provide and operate equipment adequate to keep the bottom of excavations free of water. Remove all water during the placing of fill and at such other times as required for efficient and safe execution of the Work.

D. Place and spread fill materials in lifts of uniform thickness, in a manner that avoids segregation, and compact each lift to specified compaction prior to placing succeeding lifts. Slope lifts to conform to final grades or as necessary to keep placement surfaces drained of water.

E. Tolerances:

1. Final Lines and Grades: The final grading for all landfill areas and drainage features shall be free of depressions that can hold water unless designed to do so; within a tolerance of 0.15 foot unless dimensions or grades are shown or specified otherwise.

2. Grade to establish and maintain slopes and drainage as shown. Reverse slopes are not permitted.

\subsection{SURVEYING}

A. At the completion of the final cover fill placement and final surface preparation and prior to placement of seeding, survey surface of graded area within the Work limits for approval by the CQA Engineer.

\subsection{RIP RAP PLACEMENT}

A. Geotextile:

1. Geotextile shall be placed prior to placing rip rap.

2. The surface upon which the geotextile is placed shall be free of loose or extraneous material and sharp objects that may damage the fabric during installation.

3. Geotextile shall be placed in conformance with the manufacturer's recommendations and as directed by the Engineer. Geotextile shall be placed loosely upon or against surface to receive geotextile so that the fabric conforms to the surface without damage when cover materials are placed.

4. Geotextile shall be joined either with overlapped joints or stitched seams. If overlapped, overlap shall be at least 24 inches.

5. Geotextile shall be anchored around the perimeter by a minimum 6-inch wide by 6-inch deep anchor trench.

B. Rock shall not be allowed to drop over 3 feet onto geotextile. 
C. Rocks shall be placed to provide a minimum of voids. The rock and gravel may be placed by dumping, and may be spread in layers by suitable equipment.

\subsection{COMPACTION}

A. Compact all materials designated to be compacted by mechanical means. Flooding or jetting will not be permitted. If compaction tests indicate that compaction or moisture content is not as specified; material placement shall be terminated and corrective action shall be taken prior to continued placement.

B. In-place density of cover material following compaction shall be no less than 78 percent and no greater than 85 percent relative compaction as determined by ASTM D698 and no greater than 103 pounds per cubic foot dry density as determined by ASTM D6938 or ASTM D1556.

\subsection{MOISTURE CONTROL}

A. Maintain moisture content uniform throughout the lift. Insofar as practicable, add water to the material at the site of excavation if the material is too dry. Supplement, if required, by sprinkling the fill.

B. Cover material shall be at least 1 percentage point dry of optimum water content per ASTM D698 prior to placement on the cover area.

C. Dry material by blading, discing, harrowing, or other methods, to hasten the drying process if necessary to meet moisture limits.

\subsection{QUALITY CONTROL}

A. A test as referred to in this Section is defined as one field density and one moisture test.

B. A minimum of five tests per acre per lift or top of cover for areas where existing cover soils will remain.

C. Provide visual-manual classification of soils per acre per lift, or for every change in material type, whichever is greater.

\subsection{PREPARATION OF SUBGRADE}

A. Deep rip soils over trenches with shanks on 3-foot centers using a minimum of two crossing passes to a minimum 18-inch depth.

B. Remove cobbles larger than 9 inches that are brought to the surface by the ripping operations. 
C. Track walk surfaces with low ground pressure dozers to smooth surface.

D. Test soils within the upper 12 inches of the subgrade to ensure compliance with the compaction requirements and correct density as required by compaction or ripping.

3.08 COVER FILL-GENERAL

A. Place each layer in an uncompacted lift no greater than 18-inches loose thickness and track with small wide-tracked bulldozer (equivalent to a Caterpillar D6M-LGP). Maximum compaction shall be 85 percent relative compaction at moisture content that is no greater than 1 percent dry of optimum moisture content. Use ripping, tilling, or other method approved by the Engineer to break up any compaction greater than 85 percent relative compaction.

B. Rubber-tired vehicles shall not be driven on final surfaces. Specific haul roads for rubber-tired vehicles may be constructed provided they are ripped, tilled, and loosened as specified herein at completion of haul.

C. Minimize construction equipment travel over soil cover material following placement and compaction.

D. For Existing Cover Soils to Remain: prepare in accordance with Section 3.07 Preparation of Subgrade.

END OF SECTION 
This page intentionally left blank. 


\section{SECTION 312316 \\ EXCAVATION}

\section{PART 1 GENERAL}

1.01 DESCRIPTION OF WORK

A. This Section covers all excavation associated with construction of the 92-Acre Grading and Drainage project.

B. Excavate borrow soils and drainage channels adjacent to the ET final cover as shown on the Drawings.

1.02 DEFINITIONS

A. Common Excavation: Removal of material not classified as rock excavation.

B. Engineer: Design engineer of record providing submittal review, design clarifications, and other services during construction.

1.03 QUALITY ASSURANCE

A. Provide adequate survey control to avoid overexcavation.

1.04 WEATHER LIMITATIONS

A. Material excavated when frozen or when air temperature is less than 32 degrees $F$ shall not be used as fill or backfill until material completely thaws.

B. Material excavated during inclement weather shall not be used as fill or backfill until after material drains and dries sufficiently for proper compaction.

\subsection{SEQUENCING AND SCHEDULING}

A. Demolition: Verify locations shown to be demolished by others have been removed prior to clearing and grubbing.

B. Clearing and Grubbing: Complete applicable Work specified in Section 3110 00, Site Clearing, prior to excavating. 
PART 2 PRODUCTS (NOT USED)

PART 3 EXECUTION

3.01 GENERAL

A. Excavate to lines, grades, and dimensions shown and as necessary to accomplish Work. Excavate to within tolerance of plus or minus $0.1 \mathrm{foot}$, except where dimensions or grades are shown or specified as maximum or minimum.

B. Do not overexcavate without written authorization of Engineer.

3.02 UNCLASSIFIED EXCAVATION

A. Excavation is unclassified. Complete all excavation regardless of the type, nature, or condition of the materials encountered.

3.03 CUT SLOPES

A. Shape, trim, and finish cut slopes to conform to lines, grades, and crosssections shown, with proper allowance for slope protection, where shown.

B. Round tops of cut slopes in soil to not less than a 6-foot radius, provided such rounding does not adversely impacts existing facilities, adjacent property, or completed Work.

3.04 STOCKPILING EXCAVATED MATERIAL

A. Stockpile excavated material that is suitable for use as select native fill material until material is needed.

B. Confine stockpiles to within approved work areas. Do not obstruct existing roads.

C. Do not stockpile excavated material adjacent to trenches and other excavations.

D. Do not stockpile excavated materials near or over existing facilities, adjacent property, or completed Work.

3.05 DISPOSAL OF SPOIL

A. Dispose of excavated materials, which are unsuitable or not needed for select native fill material, in spoil disposal areas acceptable to Owner.

END OF SECTION 


\section{SECTION 329301 SEEDING}

\section{PART 1 GENERAL}

\subsection{WORK INCLUDED}

A. This section covers the Work necessary to perform final soil preparation, seeding, and mulching of the final cover

B. Work limits include the entire final cover area, generally described as the area bordered by the toe of the 3:1 sideslopes.

\subsection{ACRONYMNS, ABBREVIATIONS, AND DEFINITIONS}

A. The following is a list of acronyms which may be included in this section:

1. DOE

2. FHA

3. NNSA/NSO

4. $\quad$ NSTec

5. PLS
Department of Energy

Federal Housing Administration

U.S. Department of Energy, National Nuclear Security Administration, Nevada Site Office National Security Technologies, LLC pure live seed

\subsection{REFERENCES}

A. The following is a list of standards which may be referenced in this section:

1. Nevada State Seed Law

\subsection{SUBMITTALS}

A. Seed vendor's certified statement for each seed mixture required, stating botanical and common name, percentages by weight, and percentages of purity, germination, and weed seed for each seed species.

B. Certified weed free straw guarantee.

\subsection{QUALITY ASSURANCE}

A. Installer shall have experience restoring or enhancing desert environs, and installing landscape materials, with documented experience in performing landscape work of comparable size, scope, and quality.

B. Supervision: Provide the services of at least one qualified person who shall be present at all times during execution of the Work of this Section. That 
individual, who shall direct the Work, shall be thoroughly familiar with the types of materials being installed and the proper methods for their installation.

1.06 DELIVERY, HANDLING, AND STORAGE

A. All mulch shall be delivered to the site in manageable bale sizes that are able to be spread on the final cover after planting to control wind and water erosion.

B. Notify Engineer at least 3 working days in advance of each delivery.

C. Seed will be mixed and packaged in durable bags. Bags will be of woven plastic or a material that will allow air movement through the bag. Individual bags will not exceed $50 \mathrm{lbs}$ in weight.

D. Delivery:

1. Deliver materials to the Work site in original unopened containers bearing manufacturer's guaranteed chemical analysis, weight, manufacturer's name, trademark, and conformance with state law.

E. Storage:

1. Protect packaged materials from deterioration during storage.

2. Seed to be stored in an area protected from natural elements (rain, sun), low moisture, and rodent-proof.

3. Straw is to be staged near the site.

\subsection{SITE CONDITIONS, SCHEDULING, AND SEQUENCING}

A. Seeding shall be completed within the first allowable planting period following Engineer acceptance of cover surface final grading.

B. Seeding shall be completed between October 15 and December 15 or between February 1 and March 15.

\subsection{SEED MIX QUALITY CONTROL}

A. Source Quality Control:

1. General: Do not ship any materials until approval of submittals have been obtained from the Engineer. Ship materials with certificates of inspection required by governing authorities. Comply with State regulations applicable to revegetation material.

2. Do not make substitutions. If specified materials are not obtainable, submit proof of non-availability to Engineer, together with proposal for use of equivalent material. 
B. Analysis and Standards: Package standard products with manufacturer's certified analysis.

C. All seed purchased will have been tested for purity and viability by a certified seed laboratory within 12 months of the date that the order is placed. Proof of certification (i.e. name of seed lab, test date, and test results) will be provided on the seed tag.

D. All seed should be collected preferably from central Nevada. Seed from regions other than central Nevada may or may not be accepted. If the vendor has no seed available from central Nevada for certain species, they must consult with and obtain written approval from the Engineer and NSTec scientists before the seed is shipped or the seed may be returned to vendor at vendor's cost.

E. A tag listing the following information will be provided for each species:

1. Common name

2. Seed origin, including county, state, and elevation when possible (must identify state at a minimum)

3. Pure seed $(\%)$

4. Other crop $(\%)$

5. Inert matter $(\%)$

6. Weed seed $(\%)$

7. Noxious weed seed

8. Germination (\%) TZ-tetrazolium or Fill/Cut Test

9. Seedmix number. This number must be linked to each individual seedlot from which the mix was made in order to trace any species in the mix back to its seedlot.

10. Net weight (bulk and PLS)

11. Hard seed (\%)

12. Date tested

13. Name and address of seed company

14. Variety, if applicable

F. Seed shall not contain prohibited noxious weed seed. Wet, moldy, otherwise damaged seed, or seed without verification of test by a certified seed laboratory shall not be accepted.

\subsection{TRAFFIC CONTROL}

A. The only vehicle allowed to be driven across the final cover surface will be the low ground pressure tractor used to drill seed and spread and crimp straw while performing those operations. Tractor and foot traffic across the barrier surface shall be minimized and shall not be allowed following heavy rain events to prevent rutting and compaction of cover soils. 


\section{PART 2 PRODUCTS}

\subsection{SEED}

\section{A. Seed Mixes:}

1. Weights will be by pure live seed (PLS)

2. Seed of the following composition, proportion, and quality shall be applied at a rate of 21.4 (pure live seed) pounds per acre:

\begin{tabular}{|c|c|c|c|}
\hline \multicolumn{2}{|c|}{ Kind and Variety of Seed in Mixture } & \multirow{2}{*}{$\begin{array}{l}\text { PLS } \\
\text { (lb/ac) }\end{array}$} & \multirow{2}{*}{$\begin{array}{l}\text { \% by } \\
\text { Weight }\end{array}$} \\
\hline Scientific Name & Common Name & & \\
\hline \multicolumn{4}{|l|}{ Shrubs } \\
\hline Ambrosia dumosa & White bursage & 2 & 9.3 \\
\hline Atriplex polycarpa & Desert Saltbush & 0.05 & 0.2 \\
\hline Atriplex confertifolia & Shadscale & 1 & 4.7 \\
\hline Atriplex canescens & Fourwing saltbush & 1 & 4.7 \\
\hline Encelia farionosa & Brittlebush & 0.5 & 2.3 \\
\hline Ephedra nevadensis & Nevada Ephedra & 3 & 14.0 \\
\hline Ericameria nauseosa & Rubber Rabbitbrush & 0.3 & 1.4 \\
\hline Eriognum fasciculatum & Buckwheat & 1 & 4.7 \\
\hline Grayia spinosa & Spiny Hopsage & 0.5 & 2.3 \\
\hline Hymenoclea salsola & Burrobush & 0.1 & 0.5 \\
\hline Krascheninnikovia lanata & Winterfat & 5 & 23.4 \\
\hline Larrea tridentate & Creosote & 2 & 9.3 \\
\hline Lycium andersonii & Desert Thorn & 0.2 & 0.9 \\
\hline \multicolumn{4}{|l|}{ Grasses } \\
\hline Achnatherum hymenoides & Indian Ricegrass & 3 & 14.0 \\
\hline Elymus elymoides & Squirreltail & 1 & 4.7 \\
\hline \multicolumn{4}{|l|}{ Forbs } \\
\hline Baileya multiradiata & Marigold & 0.25 & 1.2 \\
\hline Sphaeralcea ambigua & Globe Mallow & 0.25 & 1.2 \\
\hline Penstemon palmeri & Palmer's penstemon & 0.25 & 1.2 \\
\hline TOTAL & & 21.4 & 100.00 \\
\hline
\end{tabular}

3. Seed Law. All seeds shall conform to the requirements of the Nevada State Seed Laws, and where applicable, the Federal Seed Act.

4. Noxious Weed Seed. All seed shall be free of seeds of weeds listed as primary noxious by the Nevada State Seed Law. Seeds shall not contain seeds of weeds listed as secondary noxious by the Nevada State Seed Law, singly or collectively in excess of the labeling tolerance specified by the Nevada State Seed Law. 
5. Rejection. When seeds furnished under this specification fail to meet the requirements within tolerance, as provided by the Nevada State Seed Law, the lot shall be rejected or subjected to fiscal adjustment.

6. Re-Cleaning. Seeds shall be thoroughly re-cleaned and of uniformly good quality and appearance throughout each lot.

7. Preparation for Delivery. Seeds shall be packed in clean, sound containers of uniform weight. Seed shall be labeled as required by Law.

\subsection{STRAW MULCH}

A. Mulch shall be certified weed-free straw free of weed seed, sticks, roots, trash, and other foreign material.

B. Straw mulch will have an average stem length of $12 "$, with a minimum length of 8". Straw bales should be of uniform size with a minimum of two strands of twine (no wire) to secure each bale. Bales should be between 60 and 110 pounds. Several bales will be checked by the Engineer and NSTec Scientists prior to delivery to determine if the straw meets the above specifications. Several bales will also be checked upon delivery to determine if the above specifications have been met. If specifications are not met, the straw will not be accepted and/or will be returned to the vendor at vendor's cost.

C. Straw mulch shall be spread on the surface at a rate of 2 tons per acre.

\section{PART 3 EXECUTION}

\subsection{FINAL SURFACE PREPARATION}

A. Prior to seeding, grade areas to smooth, even surface with loose, uniformly fine texture.

1. Disc soils to a minimum penetration depth of 3 inches in two crossing directions. Remove any rocks that impede this minimum depth of penetration.

2. One pass of a harrow for final surface preparation prior to seeding. The direction of the final harrow pass shall be conducted on contour (perpendicular to barrier slope) to aid in controlling runoff and erosion.

B. The surface shall be finished to not more than 0.15 foot above or below the established grade or approved cross section.

C. Restore prepared areas to specified condition if eroded or otherwise disturbed after preparation and before planting. 
A. All planting equipment including the tractor and seed drill shall be free of foreign matter including soil, seed, fertilizer, mulch or other material transported from another location. All equipment shall be pressure-washed by the Contractor offsite and checked by the Engineer prior to use.

B. Seeding shall be performed with a seed drill manufactured for that purpose and normally used commercially in the area.

1. The depth of seed placement shall be no less than 0.5 inch and no greater than 2 inches

C. The seed mix shall be evenly applied throughout the planting area.

\subsection{MULCHING}

A. Mulching to occur when winds are less than 10 miles per hour.

B. Mulch shall be spread evenly over the surface using a straw blower.

C. Within 24 hours of mulch application, mulch shall be crimped into the soil to a depth of 1 to 2 inches using a disc crimper.

D. Mulch shall be crimped into soils on contour (perpendicular to barrier slope) to aid in controlling runoff and erosion.

\subsection{FINAL INSPECTION AND ACCEPTANCE}

A. Final inspection will be conducted when all seeding has been completed. Submit notice to the Engineer requesting final inspection at least one (1) week prior to the anticipated date.

B. Acceptance will be performed by the CQA Engineer in accordance with the CQA Plan. The CQA Plan is made part of these specifications by reference.

\section{END OF SECTION}




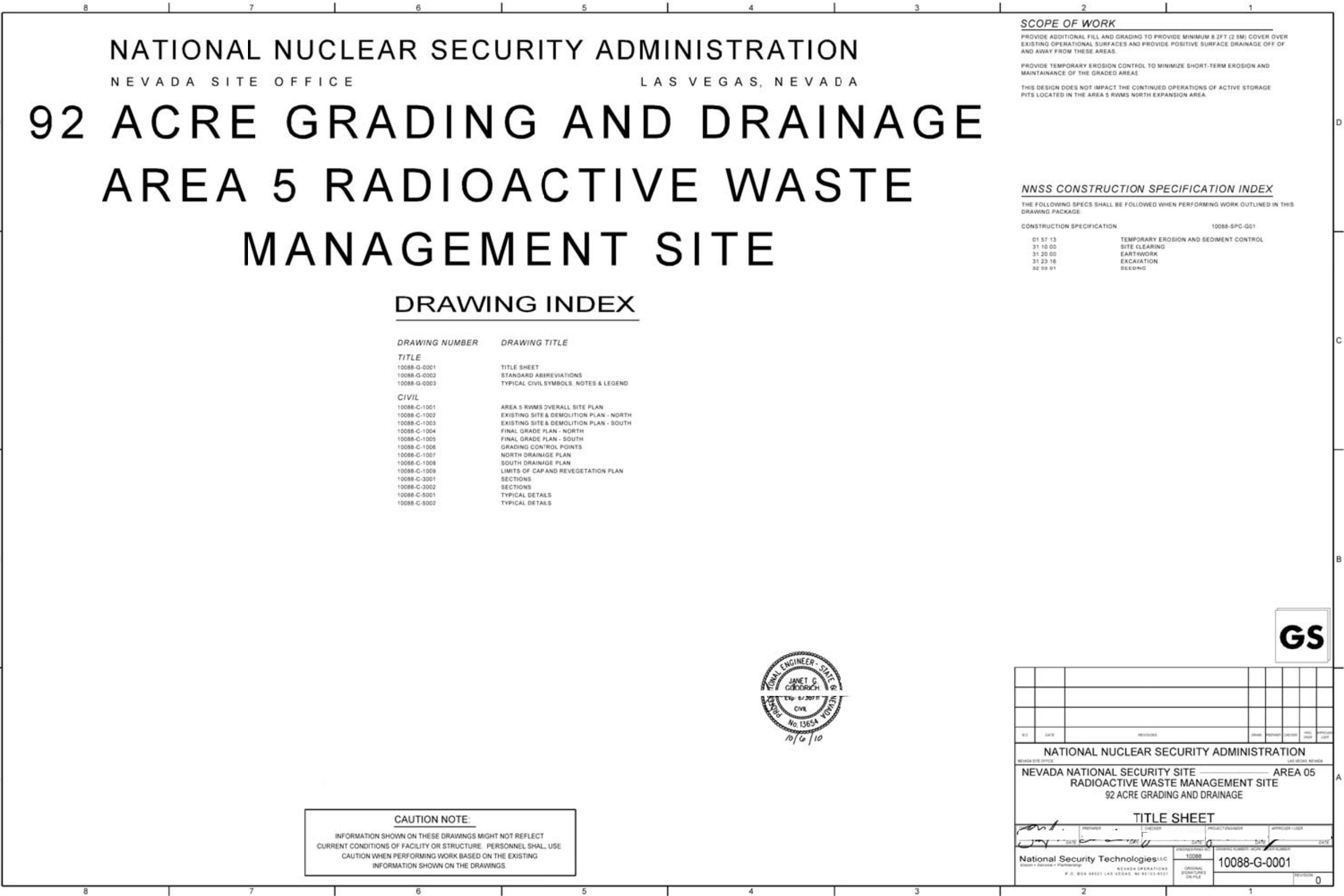

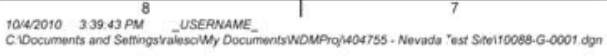




\section{STANDARDABBREVIATIONS}

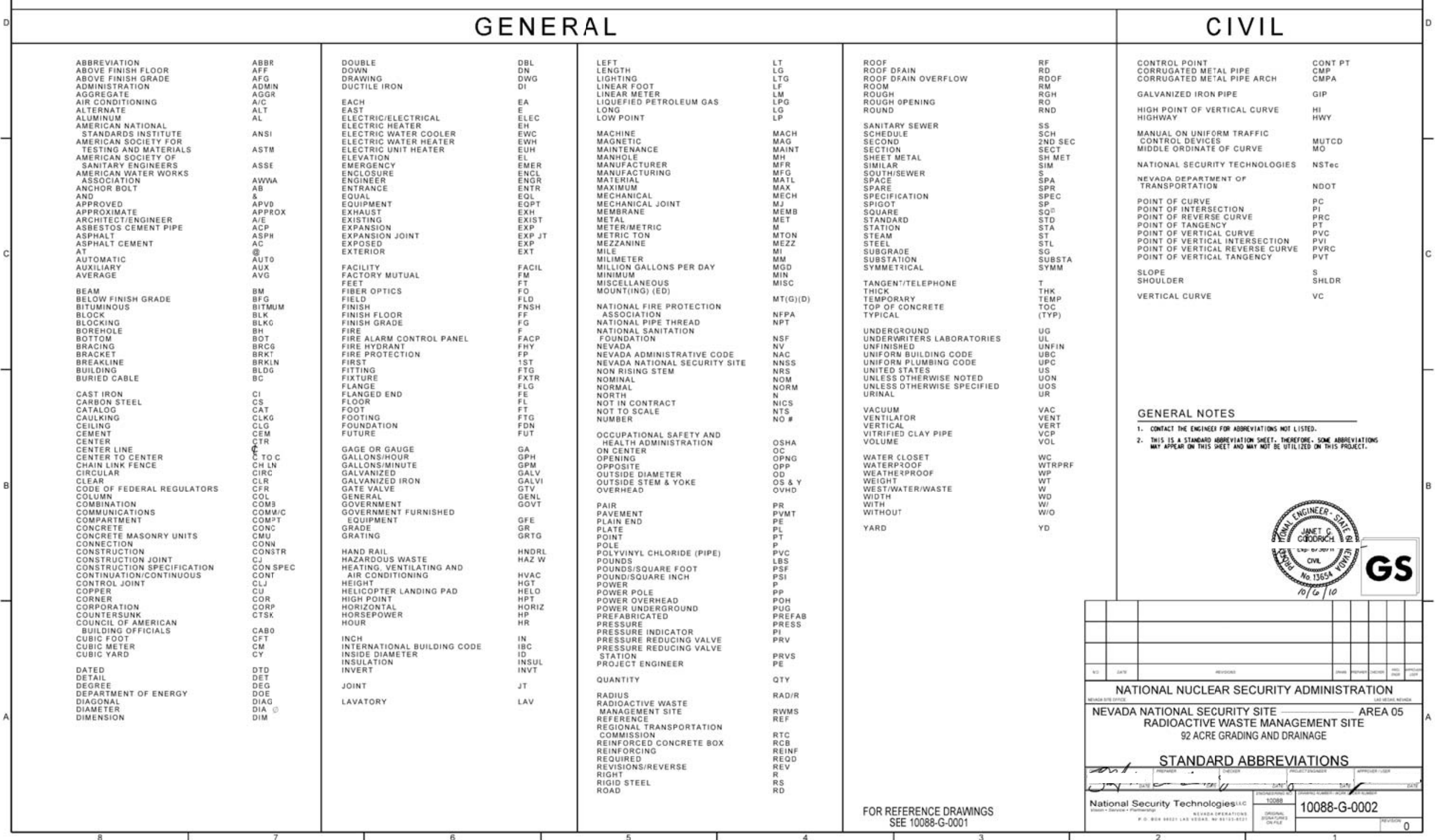

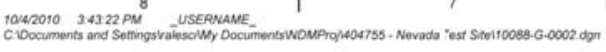




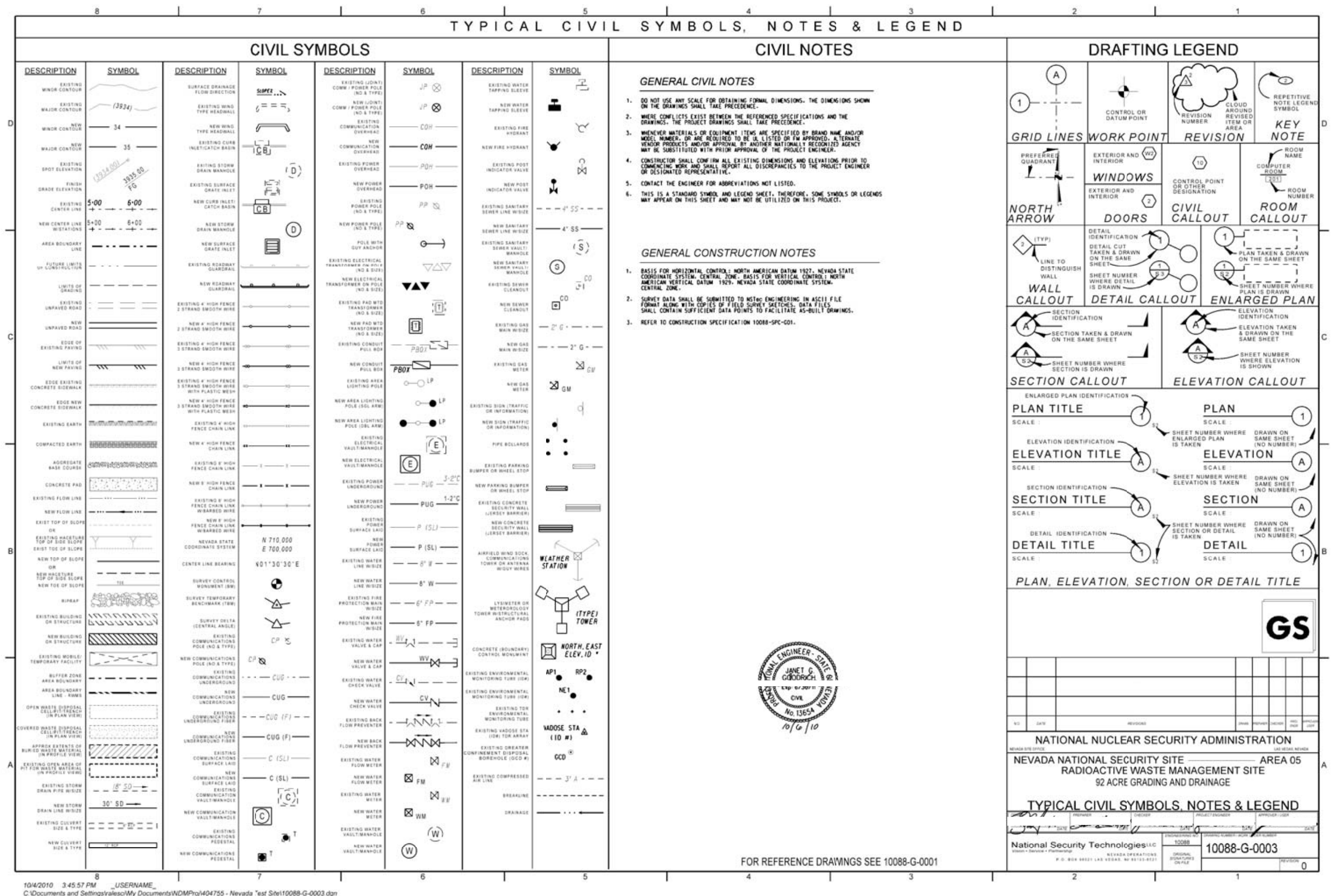




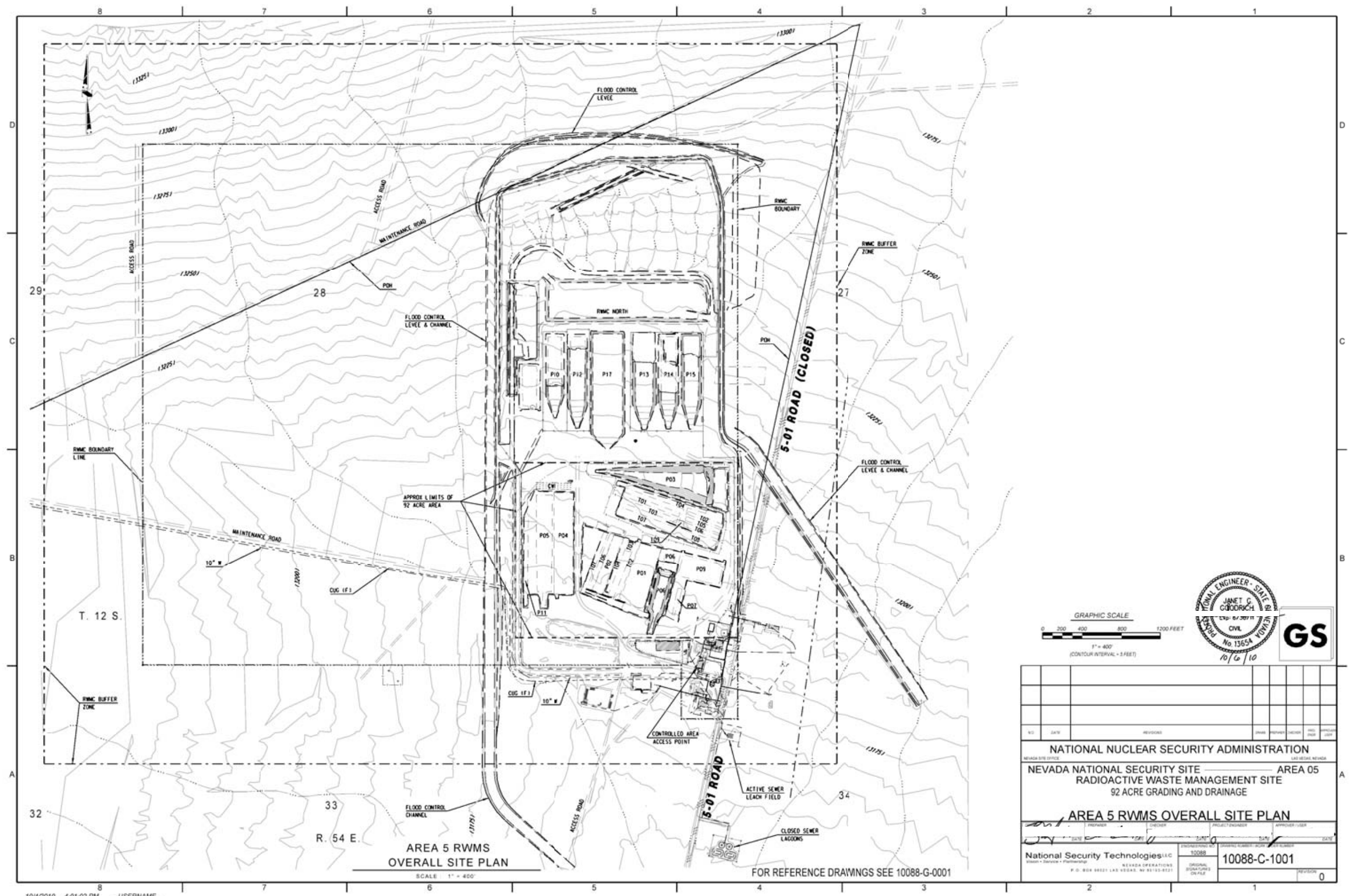

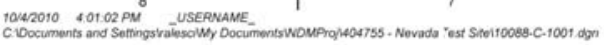




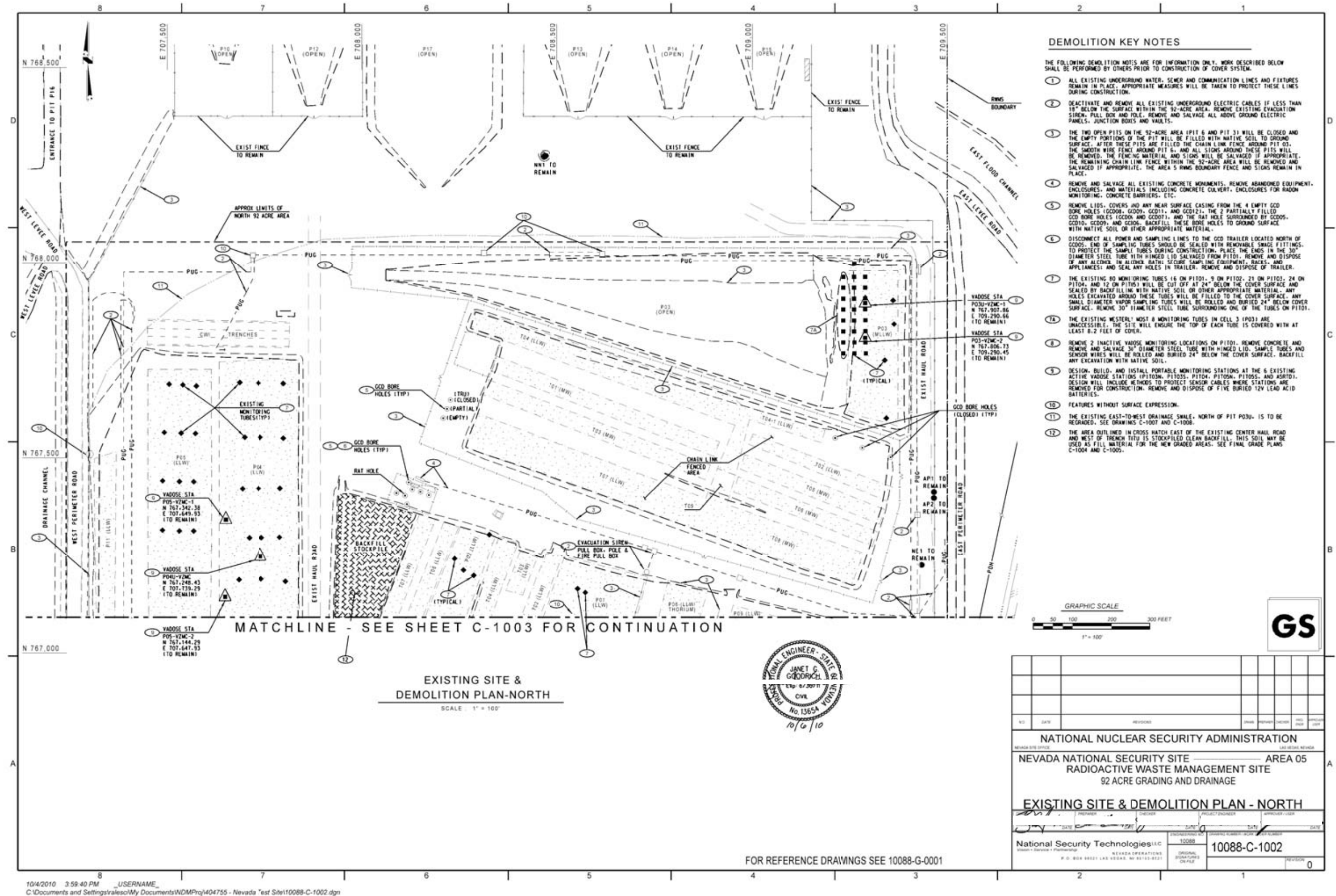

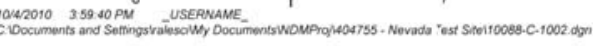




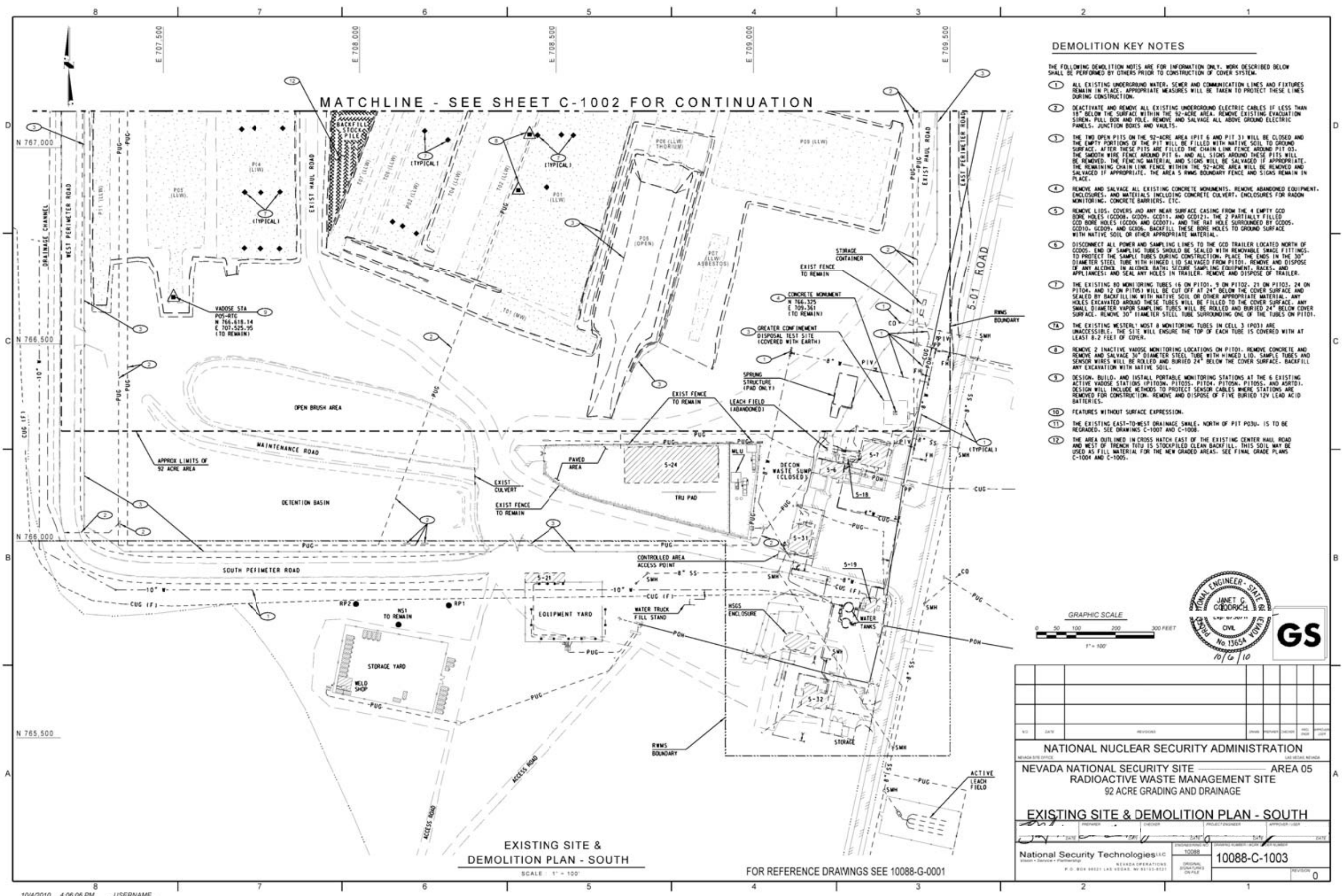

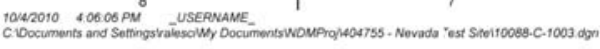




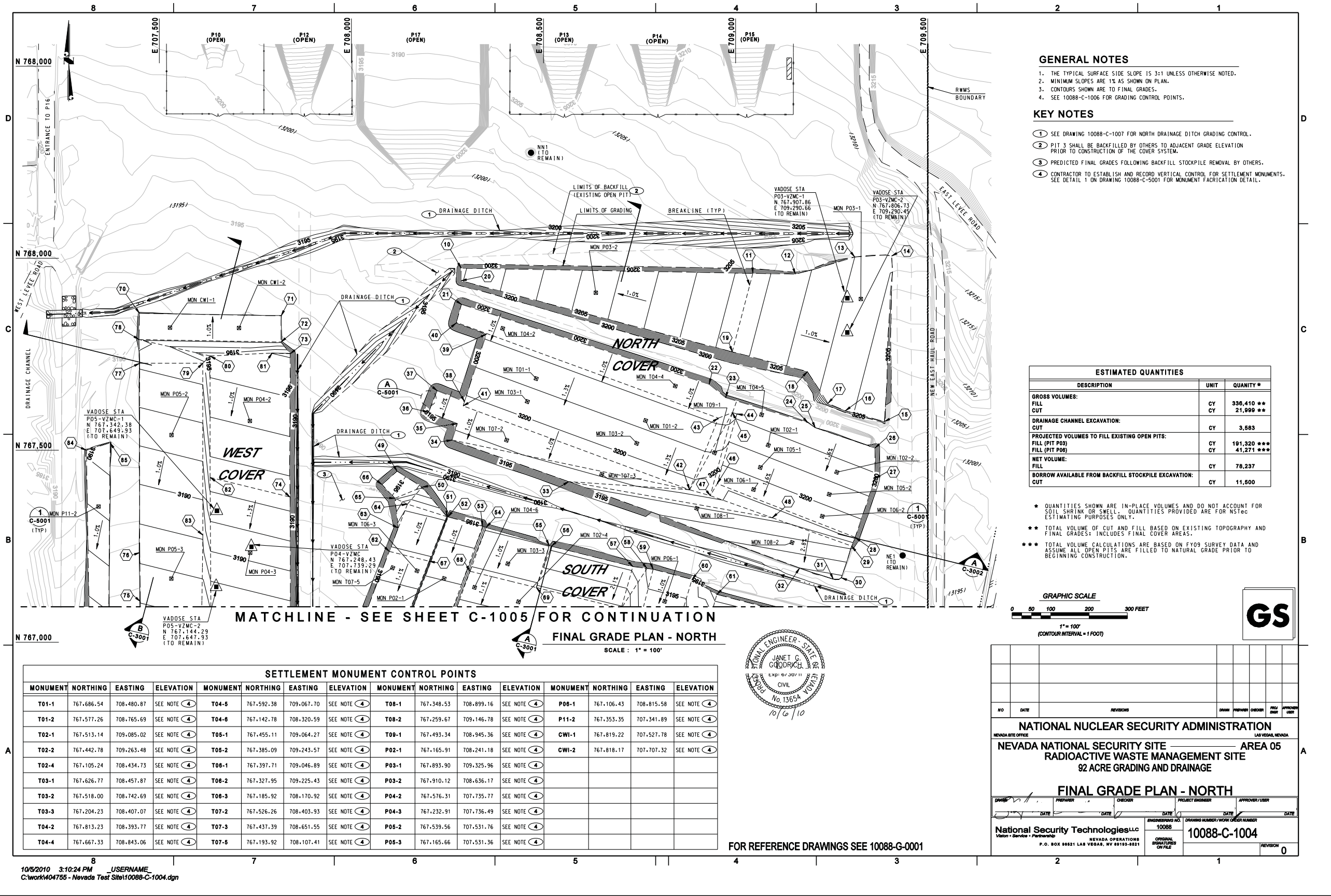









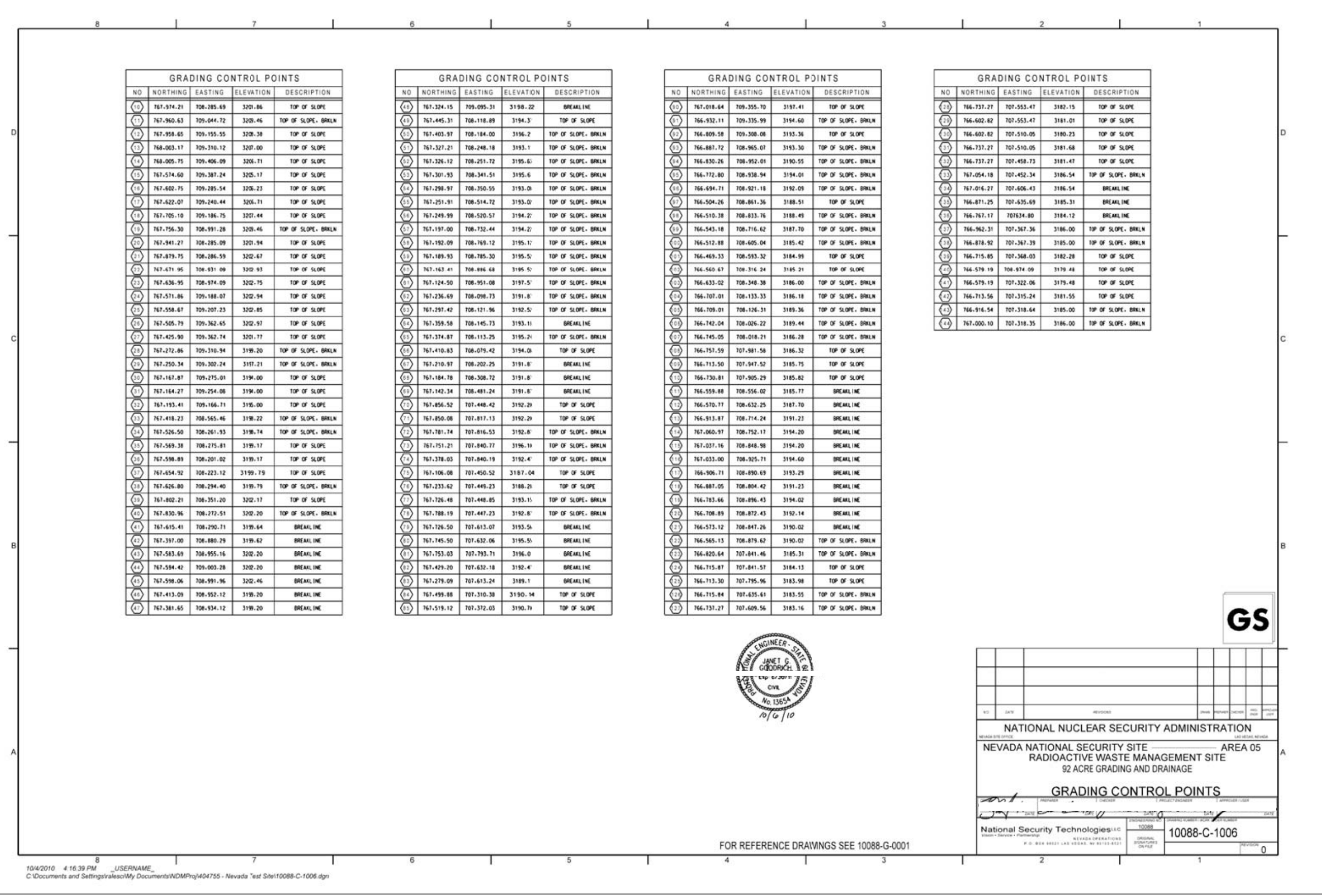




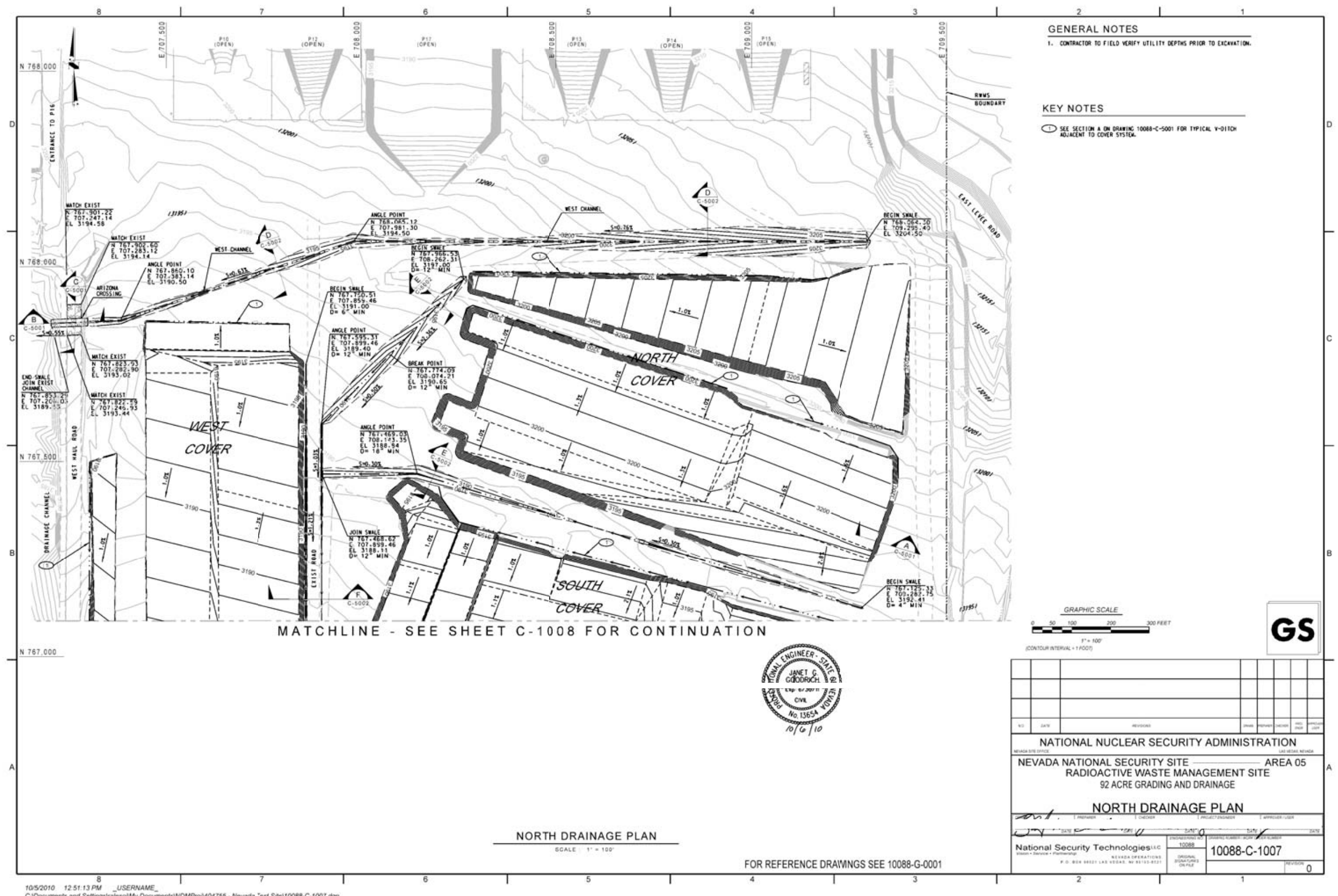

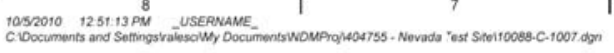




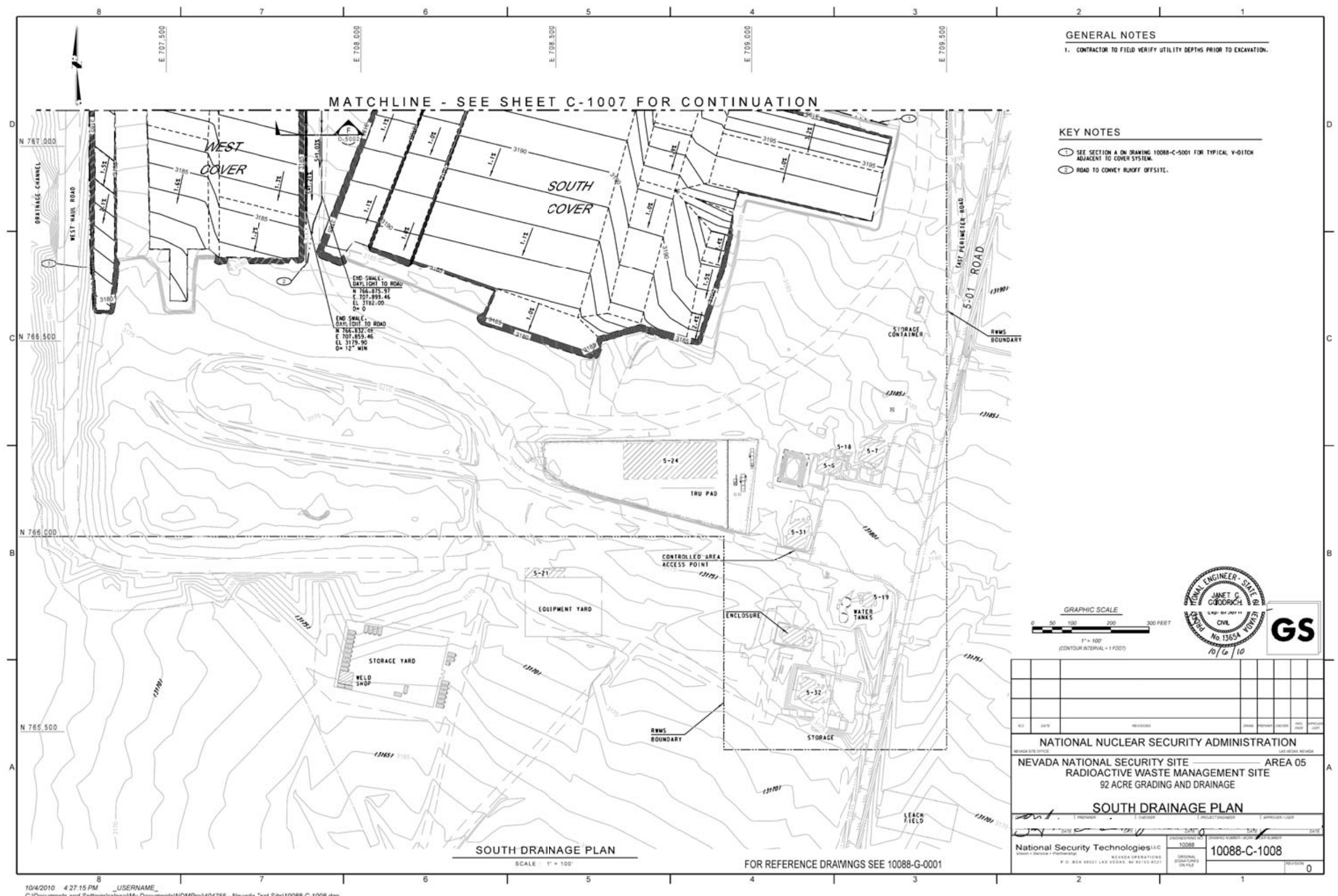

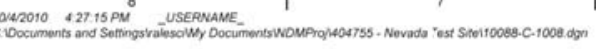




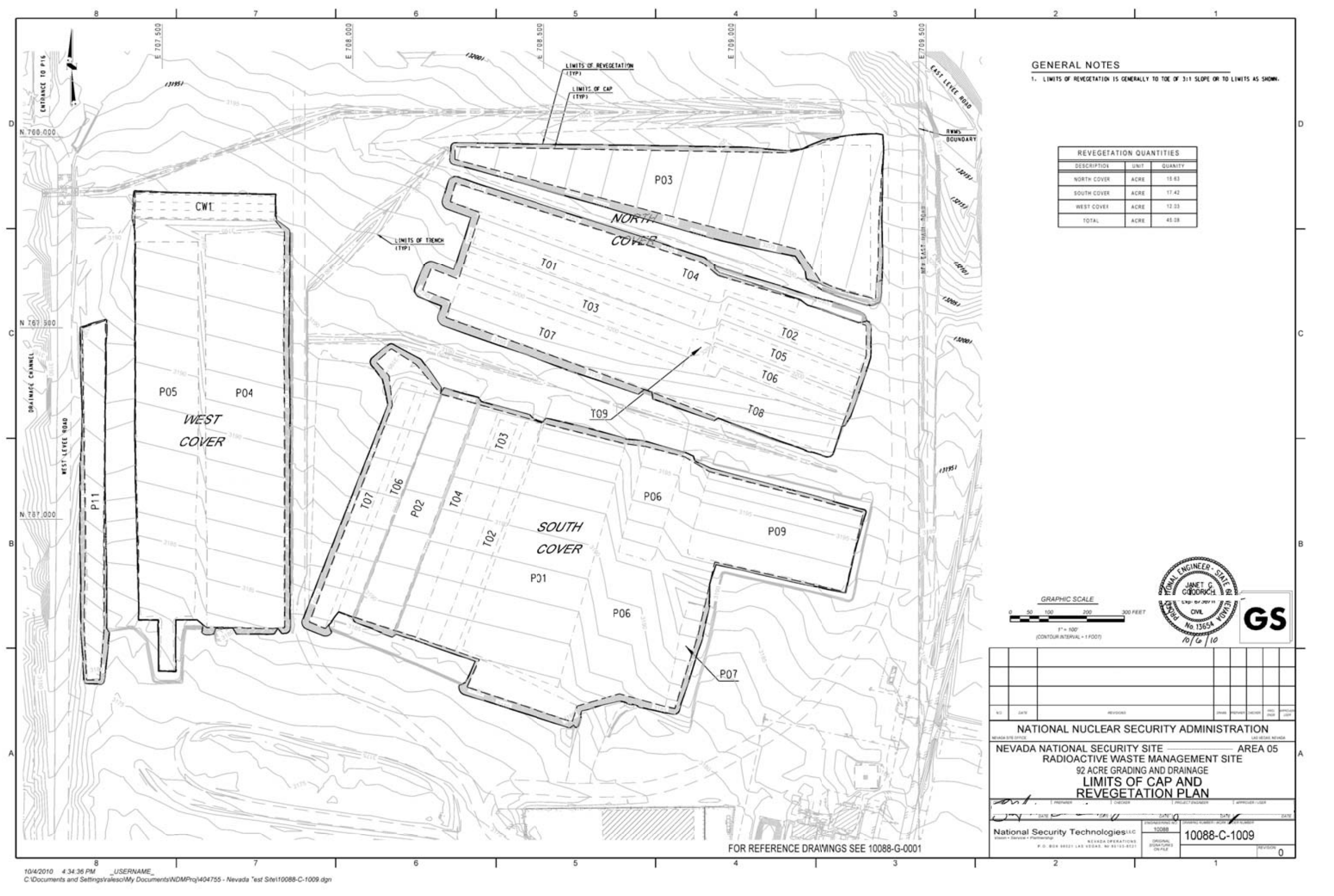




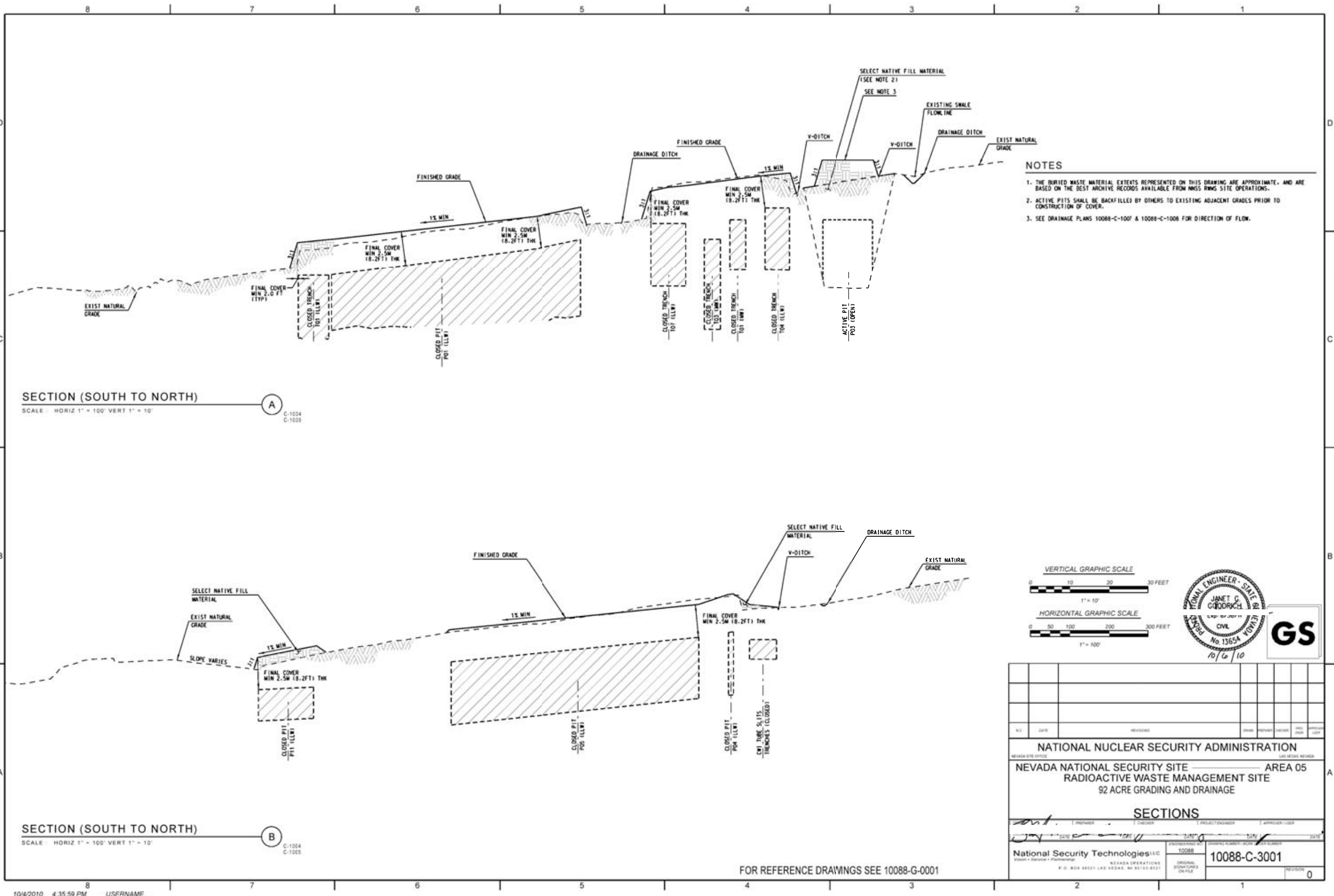

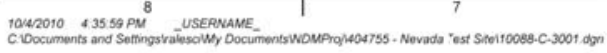




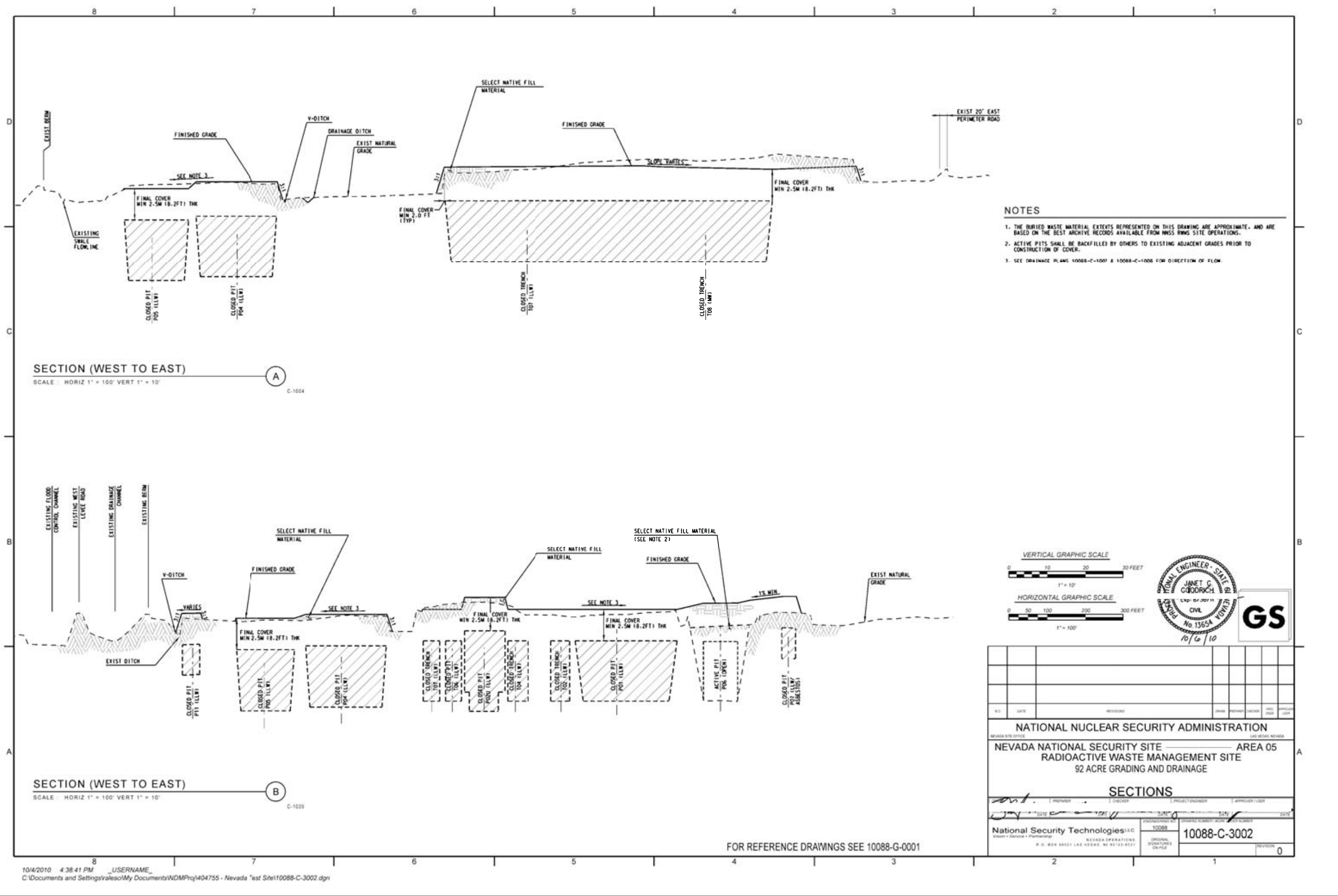







92-Acre Area and CAU 111 CADD/CAP Section: Appendix D

Revision: 1

Date: November 2010

\section{APPENDIX D}

\section{Project ORganization}


92-Acre Area and CAU $111 \mathrm{CADD} / \mathrm{CAP}$

Section: Appendix D

Revision: 1

Date: November 2010

THIS PAGE INTENTIONALLY LEFT BLANK 


\section{PROJECT ORGANIZATION}

For this project, the U.S. Department of Energy, National Nuclear Security Administration Nevada Site Office (NNSA/NSO) points of contact are as follows:

NNSA/NSO LLW Federal Sub-Project Director: Jhon T. Carilli

Telephone Number: (702) 295-0672

NNSA/NSO Waste Management Federal Project Director: E. Frank Di Sanza

Telephone Number: (702) 295-5855

The identification of the project Health and Safety Officer and the Quality Assurance Officer can be found in the appropriate plan. However, personnel are subject to change, and it is suggested that the appropriate U.S. Department of Energy Federal Sub-Project Director be contacted for further information. The Task Manager will be identified in the Federal Facility Agreement and Consent Order Monthly Activity Report prior to the start of field activities. 
92-Acre Area and CAU $111 \mathrm{CADD} / \mathrm{CAP}$

Section: Appendix D

Revision: 1

Date: November 2010

THIS PAGE INTENTIONALLY LEFT BLANK 
92-Acre Area and CAU $111 \mathrm{CADD} / \mathrm{CAP}$

Section: Appendix E

Revision: 1

Date: November 2010

APPENDIX E

\section{CORRECTIVE ACTION INVESTIGATION RESUltS}


92-Acre Area and CAU $111 \mathrm{CADD} / \mathrm{CAP}$

Section: Appendix E

Revision: 1

Date: November 2010

THIS PAGE INTENTIONALLY LEFT BLANK 


\section{CORRECTIVE ACTION INVESTIGATION RESULTS}

A Corrective Action Investigation was not performed for this project. The results of site characterization, environmental monitoring, and modeling that have been performed for the site are presented in Section 2.2 of this document. These studies and the waste inventory are also summarized in the Data Quality Objectives provided in Appendix A of this document. 
92-Acre Area and CAU $111 \mathrm{CADD} / \mathrm{CAP}$

Section: Appendix E

Revision: 1

Date: November 2010

THIS PAGE INTENTIONALLY LEFT BLANK 
92-Acre Area and CAU 111 CADD/CAP Section: Appendix F

Revision: 1

Date: November 2010

APPENDIX F

\section{DATA AsSESSMENT}


92-Acre Area and CAU $111 \mathrm{CADD} / \mathrm{CAP}$

Section: Appendix F

Revision: 1

Date: November 2010

THIS PAGE INTENTIONALLY LEFT BLANK 


\section{DATA ASSESSMENT}

This section is not applicable to this project because Corrective Action Investigation data were not collected. 
92-Acre Area and CAU $111 \mathrm{CADD} / \mathrm{CAP}$

Section: Appendix F

Revision: 1

Date: November 2010

THIS PAGE INTENTIONALLY LEFT BLANK 
92-Acre Area and CAU 111 CADD/CAP Section: Appendix G

Revision: 1

Date: November 2010

\section{Appendix G}

\section{EVALUATION OF RISK}


92-Acre Area and CAU $111 \mathrm{CADD} / \mathrm{CAP}$

Section: Appendix G

Revision: 1

Date: November 2010

THIS PAGE INTENTIONALLY LEFT BLANK 


\section{EVALUATION OF RISK}

A detailed assessment and systematic analysis of the potential risks posed by the Area 5 Radioactive Waste Management Site to the public and the environment and a comparison of those risks to established performance objectives was completed as part of the Performance Assessment described in Section 2.1.9 of this document and Section 1.2.1 of the Data Quality Objectives in Appendix A.

The Performance Assessment predicts, through modeling, the future behavior of complex environmental systems and human populations. The high potential evapotranspiration, low rainfall, and thick vadose zone at the Area 5 Radioactive Waste Management Site prevent contaminants from being leached from the waste to the aquifer. The extremely low water content of the near-surface alluvium minimizes the potential for upward advection and diffusion of dissolved solutes. The potential for release by plant uptake is reduced by the low productivity and shallow rooting depth of native floral communities. These characteristics combine to minimize the release of contaminants from the intact waste disposal units.

The impact of contaminants released from the facility is minimized by the low population density and limited land use options near the site. Protection of groundwater resources is ensured by the natural properties of the disposal site rather than the performance of engineered barriers or stabilized waste forms. 
92-Acre Area and CAU $111 \mathrm{CADD} / \mathrm{CAP}$

Section: Appendix G

Revision: 1

Date: November 2010

THIS PAGE INTENTIONALLY LEFT BLANK 
92-Acre Area and CAU 111 CADD/CAP

Section: Appendix H

Revision: 1

Date: November 2010

\section{APPENDIX H}

\section{SAMPling AND ANALYSis Plan}


92-Acre Area and CAU $111 \mathrm{CADD} / \mathrm{CAP}$

Section: Appendix H

Revision: 1

Date: November 2010

THIS PAGE INTENTIONALLY LEFT BLANK 


\section{SAMPLING AND ANALYSIS PLAN}

This section is not applicable to this project because samples will not be collected for site closure. 
92-Acre Area and CAU $111 \mathrm{CADD} / \mathrm{CAP}$

Section: Appendix H

Revision: 1

Date: November 2010

THIS PAGE INTENTIONALLY LEFT BLANK 
92-Acre Area and CAU 111 CADD/CAP

Section: Appendix I

Revision: 1

Date: November 2010

\section{APPENDIX I}

\section{ReVegetation Plan for the 92-ACRE AREA}


92-Acre Area and CAU $111 \mathrm{CADD} / \mathrm{CAP}$ Section: Appendix I

Revision: 1

Date: November 2010

THIS PAGE INTENTIONALLY LEFT BLANK 


\title{
REVEGETATION PLAN FOR THE 92-ACRE AREA
}

\author{
Prepared by \\ David C. Anderson \\ Environmental Technical Services \\ Ecological Services
}

January 2008 


\subsection{INTRODUCTION}

Cover performance objectives for closure of the 92-Acre Area of the Area 5 Radioactive Waste Management Site (RWMS) at the Nevada Test Site (NTS) include minimizing the migration of water off and through the cover, creating a cover that requires minimal maintenance, maintaining the integrity of the cover over time, and meeting U.S. Department of Energy performance objectives. The cover designed for the 92-Acre Area is a vegetated monolayer that has been approved by the Nevada Division of Environmental Protection at other NTS sites and uses an evapotranspirative technique to meet cover performance objectives.

The establishment of a native plant community will minimize wind and water erosion and help maintain the integrity of the cover. The loss of water through transpiration is maximized and the potential for water to penetrate to buried waste is minimized. The vegetated cover prevents the establishment of invasive plants (Anderson and Ostler, 2002; National Security Technologies, LLC [NSTec], 2007). Invasive plants, which are typically annual plants, will not meet closure cover objectives because they do not maximize evapotranspiration and are not effective in controlling wind and water erosion, which could compromise the integrity of the cover.

This revegetation plan provides guidelines for successfully establishing a native plant community on the cover. Revegetation is the colonization of plants through natural plant succession or by human-induced means. Natural plant succession may require centuries for complete plant colonization, especially in the Mojave Desert (Angerer et al., 1995; Carpenter et al., 1986; Romney et al., 1980; Vasek et al., 1975a; Vasek et al., 1975b; Vasek, 1980; Wallace et al., 1980; Webb and Wilshire, 1980). However, human-induced means may shorten the time for establishment of a viable plant community. Various revegetation efforts in arid and semi-arid regions of the Southwest have shown that establishing a plant community by re-seeding is practical and cost effective when proper revegetation techniques are employed (Anderson, 1987; Anderson and Ostler, 2002; Bainbridge et al., 1995; Clary, 1983; Edgerton, Germeshausen, and Grier Energy Measurements, Inc., [EG\&G/EM], 1993; EG\&G/EM, 1994; Graves et al., 1978; Kay, 1979; Ostler et al., 2002a; Trw Environmental Safety Systems, Inc., 1999).

Revegetation in this area presents unique challenges. The site is located in the harsh Mojave/Great Basin Transition Desert, which is characterized by extreme temperatures and limited, erratic precipitation. Perennial plant establishment under natural conditions usually occurs only during favorable rainfall years (Anderson and Ostler, 2002; Beatley, 1975; Romney et al., 1980; Wallace and Romney, 1972), which occur approximately one out of five years (Ries and Day, 1978). This low and unpredictable precipitation is almost without exception the factor limiting successful revegetation in the arid/semi-arid Southwest (May, 1975).

The revegetation strategy outlined in this plan employs proven reclamation techniques. Site preparation is the first critical task, followed by seeding with native adapted species, mulching to conserve soil moisture, supplemental irrigation to ensure seed germination and plant establishment, and monitoring to evaluate revegetation success and identify any remedial actions necessary to ensure the maintenance of a viable vegetative cover (Ostler et al., 2002a; Winkel et al., 1999). Timing is paramount to the success of this strategy. Late fall and early spring are the best times for successful seed germination and eventual plant establishment. The late fall seeding window is from approximately October 15 to December 15, and the spring window is February to early March. Implementation of these techniques creates the optimum conditions for seed germination and plant establishment (Anderson and Ostler, 2002; Ostler et al., 2002a). 


\subsection{PROCEDURES}

\subsection{Site Preparation}

The top 12 inches (in.) of soil will have physical and chemical characteristics that support plant growth (Table I-1). Appropriate amendments may be used to enhance germination and establishment of seeded species. Soil amendments could include 1) fertilizers, 2) organic matter, 3) water-holding copolymers, and 4) remedies for sodic soils such as gypsum.

TABle I-11. Suitable SoIl PARAMETERS FOR REVEgetation*

\begin{tabular}{|c|c|c|}
\hline \multirow{2}{*}{ SOIL PARAMETER** } & \multicolumn{2}{|c|}{ SUITABILITY } \\
\hline & GOOD & FAIR \\
\hline Texture & $\begin{array}{l}\text { Fine sandy loam, very fine sandy } \\
\text { loam, loam, silt loam, sandy loam }\end{array}$ & $\begin{array}{l}\text { Clay loam, sandy clay loam, silty clay } \\
\text { loam }\end{array}$ \\
\hline Salinity $(\mathrm{EC}, \mathrm{mmhos} / \mathrm{cm})$ & $<3$ & 3 to 6 \\
\hline $\begin{array}{l}\text { Alkalinity (Exchangeable Sodium } \\
\text { Percentage) }\end{array}$ & $<4$ & 4 to 8 \\
\hline $\mathrm{pH}$ & 6.1 to 7.8 & $\begin{array}{l}5.1 \text { to } 6.1 \\
7.9 \text { to } 8.4 \\
\end{array}$ \\
\hline Organic Matter (Percentage) & $>1.5$ & 0.5 to 1.5 \\
\hline
\end{tabular}

*U.S. Department of Agriculture (USDA) Forest Service, 1979

**Parameters are listed in order of relative importance.

A key component of site preparation is alleviation of soil compaction. Compacted soils are not conducive to plant growth. A sequence of ripping, disking, and harrowing will be used to alleviate soil compaction, increase water infiltration, and provide a firm seedbed for good contact between soil and seeds (Munshower, 1994; Ostler et al., 2002a). Soils will be ripped perpendicular to the slope at a depth of 12-18 in. Ripping typically creates large clods of soil, and a tractor-drawn tandem disk will be used to break up the soil clods. After disking, the site will be harrowed to create a firm seedbed. Disking and harrowing, like ripping, will be done with the contour of the area so as not to create channeling or drainage off the cover.

The cover will be constructed to allow access for revegetation equipment such as farm tractors, road graders, four wheel drive trucks, strawblowers, and tractor-drawn implements, such as drill seeders, disks, and chisel-tooth harrows or crimpers.

\subsection{SEEDING}

Plant species recommended for revegetation are native to the area (Table I-2) based on data from adjacent undisturbed areas (EG\&G/EM, 1992), visual surveys of the vegetation in the region, and a review of local literature (Beatley, 1976; Ostler et al., 2000). Most of the species have been successfully used at other revegetation projects in the area (NSTec, 2007), and most seed is available from commercial sources. The percentage of each species in the mix is based on the relative contribution of each species to the total perennial plant cover of adjacent native plant communities, the size of the seed, and performance of the species at the NTS. The final mix will depend on seed availability. Some seed may be treated by washing, chemical treatments, or mechanical treatments to break seed dormancy (Hansen, 1989; Ostler et al., 2002b). 
The site will be broadcast-seeded at a rate of 21.4 pure live seed (PLS) pounds per acre (lb/ac). Seeding will be done with a tractor-drawn seed drill having seedboxes that accommodate small, fluffy, and large seeds. Drag chains will be used behind the seed drill to cover the seed.

\section{TABLE I-2. RECOMMENDED SEEd MIX AND SEEDING RATES}

\begin{tabular}{|c|c|c|}
\hline SCIENTIFIC NAME & COMMON NAME & PLS* $1 \mathrm{~b} / \mathrm{ac}$ \\
\hline \multicolumn{3}{|l|}{ Shrubs } \\
\hline Ambrosia dumosa & White bursage & 2.00 \\
\hline Atriplex polycarpa** & Desert Saltbush & 0.05 \\
\hline Atriplex confertifolia & Shadscale & 1.00 \\
\hline Atriplex canescens** & Fourwing saltbush & 1.00 \\
\hline Encelia farionosa & Brittlebush & 0.50 \\
\hline Ephedra nevadensis & Nevada Ephedra & 3.00 \\
\hline Ericameria nauseosa & Rubber Rabbitbrush & 0.30 \\
\hline Eriognum fasciculatum & Buckwheat & 1.00 \\
\hline Grayia spinosa & Spiny Hopsage & 0.50 \\
\hline Hymenoclea salsola & Burrobush & 0.10 \\
\hline Krascheninnikovia lanata & Winterfat & 5.00 \\
\hline Larrea tridentata $^{* *^{+}}$ & Creosote & 2.00 \\
\hline Lycium andersonii $^{+}$ & Desert Thorn & 0.20 \\
\hline \multicolumn{3}{|l|}{ Grasses } \\
\hline Achnatherum hymenoides & Indian Ricegrass & 3.00 \\
\hline Elymus elymoides & Squirreltail & 1.00 \\
\hline \multicolumn{3}{|l|}{ Forbs } \\
\hline Baileya multiradiata & Marigold & 0.25 \\
\hline Sphaeralcea ambigua & Globe Mallow & 0.25 \\
\hline Penstemon palmeri & Palmer's penstemon & 0.25 \\
\hline & & Total $=21.40$ \\
\hline
\end{tabular}

*Pure Live Seed, or number of seeds per acre divided by percent germination

**Deep-rooted plants

${ }^{+}$Species should be considered for transplanting

\subsection{MULCHING}

The site will be mulched with grain straw at a rate of $4,000 \mathrm{lb} / \mathrm{ac}$. The mulch will be applied evenly over the surface with a strawblower. The mulch will then be crimped into the soil perpendicular to the slope with a tractor-drawn disk crimper to secure the straw and incorporate a portion of the straw into the soil, which will increase the amount of organic matter in the soil.

\subsection{IRRIGATION}

Irrigation is a critical component to ameliorate the harsh growing conditions due to sporadic and unpredictable precipitation. It ensures sufficient moisture for seed germination and growth during the first year. Plants typically survive harsh desert conditions if roots have penetrated deeper water sources, which can occur during the first year of growth. 
The Area 5 RWMS receives approximately 6.69 in. of precipitation annually, which is below the 9.84 in. suggested for successful reclamation (National Academy of Science, 1974). An initial period of supplemental irrigation will provide sufficient moisture for seed germination and plant establishment (Hall and Anderson, 1999; Winkel and Boone, 1999). If insufficient natural precipitation is received for several years after seeding, much of the seed will be lost to predation or poor viability (Ostler et al., 2002a; Plummer et al., 1968). Under these circumstances, the site would need reseeding to achieve revegetation success.

Prior to irrigating the site, the water source will be tested for quality. Four basic criteria are used to evaluate water quality (Ludwig et al., 1976):

1. Total soluble salt content (salinity hazard)

2. Relative proportion of sodium cations to other cations (sodium hazard)

3. Bicarbonate anion concentration as related to calcium plus magnesium cations

4. Concentration of elements that may be toxic

The irrigation system will be a solid set sprinkler-type system designed to produce an even distribution of water across the cover. Sprinkler heads are selected to apply water at the optimal rate, spray pattern, and droplet size while minimizing runoff and wind drift.

Supplemental irrigation occurs prior to, during, and after germination (Aldon et al., 1976; Danielson, 1967; Ries and Day, 1978). Irrigation prior to germination in late fall and early winter recharges the soil profile and encourages deep-rooting. Irrigation during late winter and early spring keeps surface soils moist to promote seed germination and seedling emergence. Irrigation during late spring and early summer aids plant establishment and survival over hot and dry summer months. The frequency of application is based on the amount of rainfall received and other climatic conditions.

\subsection{SCHEDULE}

Mid- to late November is the preferred period for seeding to ensure dormancy-breaking requirements for germination are met and seeds are in the ground prior to winter precipitation. Site preparation, delivery of seed and straw, and mobilization of reclamation equipment will take place prior to the seeding window. Soil amendments will be added to the soil during site preparation or seeding. Mulching and crimping will occur immediately after seeding. The irrigation system will be installed after revegetation is complete. Irrigation will then begin and continue into late June or as required.

\subsection{SPECIAL CONSIDERATIONS}

\subsubsection{Interim Soil Stabilization}

If cover construction is completed after the seeding window, revegetation may have to be rescheduled for the following fall or spring. A temporary means of soil stabilization may be required to minimize erosion. Interim soil stabilization may include applying a copolymer soil stabilizer, which typically has an effective life of 6 to 12 months depending on application rate and weather conditions. The site would be monitored following application of the copolymer to check the integrity of the soil stabilization. If the copolymer is not adequately controlling erosion, reapplication may be necessary. 
A chemical soil stabilizer may be more cost effective. However, if a more permanent stabilization of the soil is required, straw mulch followed by crimping may be appropriate. Surface soils are disked and ripped, and a layer of straw mulch is applied and crimped into the loosened soils.

\subsubsection{Transplants}

Many native plant species are difficult to establish using the direct seeding method. Two such species are Larrea and Lycium (Table I-1). The best method for establishing these species is to use transplants. The use of transplants requires more time. Seed from both species is collected from native populations of the species on or near the revegetation area. The seed is then used to grow plants under greenhouse conditions for approximately one year. After a hardening period, they are placed in the field, typically some time after seeding. Each transplant is watered as it is placed in the ground to ensure sufficient soil moisture for survival. Subsequent watering may occur using the irrigation system.

\subsubsection{Remediation}

In the unlikely event that plants do not become established, remedial action may be taken. Such action may involve additional site preparation, re-seeding, mulching, or use of transplants.

\subsection{MONITORING}

Monitoring should occur during the first 2 to 3 years to evaluate the success of revegetation and identify concerns such as erosion, poor seed germination, or poor plant establishment. Erosion is evaluated using a modified classification system used by the Bureau of Land Management (Table I-3). Monitoring focuses on erosion conditions and plant densities. The success of seed germination and plant establishment is estimated annually during the first 2 to 3 years by determining the density of plants that were seeded and those that were not seeded but have naturally invaded the site.

Long-term establishment of plants is monitoring in subsequent years, typically every 5 years or as requested. Plant density, plant cover, and other vegetative parameters are measured to provide a quantitative assessment of the success of revegetation. An undisturbed area, similar to the revegetation site, is also sampled as a reference site. 


\section{TABLE I-3. EROSION CONDITION ClASSIFICATION*}

\begin{tabular}{|c|c|c|c|}
\hline SURFACE LITTER & Pedestalling & RILLS < 9 IN. & RILLS > 9 IN. \\
\hline $1-$ Accumulating in place & 1 - No visual evidence & 1 - No visual evidence & 1 - No visual evidence \\
\hline 2 - Slight Movement & $\begin{array}{c}2 \text { - Slight pedestalling at } \\
>10 \text {-foot intervals }\end{array}$ & $\begin{array}{c}2 \text { - Rills in evidence at } \\
>10 \text {-foot intervals }\end{array}$ & 2 - Rills in evidence \\
\hline 3 - Moderate Movement & $\begin{array}{l}3 \text { - Small rocks and plants } \\
\text { pedestalling }\end{array}$ & $\begin{array}{l}3 \text { - Rills at } 10 \text {-foot } \\
\text { intervals }\end{array}$ & $\begin{array}{l}3 \text { - Rills at } 10 \text {-foot } \\
\text { intervals }\end{array}$ \\
\hline 4 - Extreme Movement & $\begin{array}{l}4 \text { - Pedestalling plants } \\
\text { and roots exposed }\end{array}$ & $\begin{array}{l}4 \text { - Rills at } 5 \text { - to } 10 \text {-foot } \\
\text { intervals }\end{array}$ & $\begin{array}{l}4 \text { - Rills at } 5 \text { - to } 10 \text {-foot } \\
\text { intervals }\end{array}$ \\
\hline $\begin{array}{l}5 \text { - Very little litter } \\
\text { remaining }\end{array}$ & $\begin{array}{l}5 \text { - Most plants and rocks } \\
\text { pedestalling and roots } \\
\text { exposed }\end{array}$ & $\begin{array}{l}5-\text { Rills at }<5 \text {-foot } \\
\text { intervals }\end{array}$ & $\begin{array}{l}5-\text { Rills at }<5 \text {-foot } \\
\text { intervals }\end{array}$ \\
\hline Rating & Rating & Rating & Rating \\
\hline
\end{tabular}

\begin{tabular}{|c|c|}
\hline Numerical Rating & Erosion Condition Class \\
\hline 0.0 to 4.0 & Stable \\
\hline 4.1 to 8.0 & Slight \\
\hline 8.1 to 12.0 & Moderate \\
\hline 12.1 to 16.0 & Critical \\
\hline 16.1 to 20.0 & Severe \\
\hline
\end{tabular}

*USDA, 1992 


\subsection{REFERENCES}

Aldon, E. F., H. W. Springfield, and W. E. Sowards, 1976. Demonstration Test of Two Irrigation Systems for Plant Establishment on Coal Mine Spoils. NCA/BCR Coal Conf. and Expo. III. Louisville, KY.

Anderson, D. C., 1987. Evaluation of Habitat Restoration on the Naval Petroleum Reserve \#1, Kern County, California. EGG 10282-2179. Santa Barbara, CA.

Anderson, D. C. and W. K. Ostler, 2002. Revegetation of Degraded Lands at U.S. Department Of Energy and U.S. Department of Defense Installations: Strategies and Successes. Las Vegas, NV.

Angerer, J. P, W. K. Ostler, W. D. Gabbert, and B. W. Schultz, 1995. Secondary Plant Succession on Disturbed Sites at Yucca Mountain, Nevada. 11265-1118 UC-702. Las Vegas, NV

Bainbridge, D. A., M. Fidelibus, and R. MacAller, 1995. Techniques for Plant Establishment in Arid Ecosystems. Restoration and Management Notes 13(2):198-202.

Beatley, J. C., 1975. Climates and Vegetation Patterns across the Mojave/Great Basin. Springfield, VA.

Beatley, J. C., 1976. Vascular Plants of the Nevada Test Site and Central Southern Nevada: Ecologic and Geographic Distributions. Springfield, VA.

Carpenter, D. E., M. G. Barbour, and C. J. Bahre, 1986. Old Field Succession in Mojave Desert Scrub.

Clary, R. F., Jr., 1983. Planting Techniques and Materials for Revegetation of California Roadsides. FHWA/USDA LPMC-2.

Danielson, R. E., 1967. Root Systems in Relation to Irrigation. Madison, WI.

Edgerton, Germeshausen, and Grier Energy Measurements, Inc., 1992. Yucca Mountain Biological Resources Monitoring Program, Progress Report FY91. Operations Report No.10617-2127. Santa Barbara, CA.

Edgerton, Germeshausen, and Grier Energy Measurements, Inc., 1993. Yucca Mountain Biological Resources Monitoring Program, Progress Report FY92. Operations Report No.10617-2195. Santa Barbara, CA.

Edgerton, Germeshausen, and Grier Energy Measurements, Inc., 1994. Yucca Mountain Biological Resources Monitoring Program, Progress Report Oct. 1992 - Dec. 1993. Operations Report No.11265-1073 UC-708. Las Vegas, NV.

EG\&G/EM, see Edgerton, Germeshausen, and Grier Energy Measurements, Inc.

Graves, W. L., B. L. Day, and W. A. Williams, 1978. Revegetation of Disturbed Sites in the Mojave Desert with Native Shrubs.

Hall, D. B. and D. C. Anderson, 1999. Reclaiming Disturbed Land Using Supplemental Irrigation in the Great Basin/Mohave Desert Transition Region after Contaminated Soils Remediation: The Double Tracks Project. Ogden, UT. 
Hansen, D. J., 1989. Reclamation and Erosion Control Using Shrubs. San Diego, CA.

Kay, B. L., 1979. Summary of Revegetation Attempts on the Second Los Angeles Aqueduct. Mojave Revegetation Notes No. 22. Davis, CA.

Ludwig, A. E., G. W. Hergert, and W. T. Franklin, 1976. Irrigation Water Quality Criteria. Colorado State University Extension Service.

May, M., 1975. Moisture Relationships and Treatments in Revegetating Strip Mines in the Arid West.

Munshower, F. F., 1994. Practical Handbook of Disturbed Land Revegetation. Boca Raton, FL.

National Academy of Science, 1974. Rehabilitation Potential of Western Coal Lands. Cambridge, MA.

National Security Technologies, LLC, 2007. Ecological Monitoring and Compliance Program Calendar Year 2006 Report. DOE/NV/25946-174. Las Vegas, NV.

NSTec, see National Security Technologies, LLC.

Ostler, W. K., D. J. Hansen, D. C. Anderson, and D. B. Hall, 2000. Classification of Vegetation on the Nevada Test Site. DOE/NV/11718--477. Las Vegas, NV.

Ostler, W. K., D. C. Anderson, D. B. Hall, and D. J. Hansen, 2002a. New Technologies to Reclaim Arid Lands User's Manual. DOE/NV/11718-477. Las Vegas, NV.

Ostler, W. K., D. C. Anderson, D. J. Hansen, and D. B. Hall, 2002b. Pre-Treating Seed to Enhance Germination of Desert Shrubs. DOE/NV/11718-715. Las Vegas, NV.

Plummer, A. P., D. R. Christensen, and S. B. Monsen, 1968. Restoring Big Game Range in Utah.

Ries, R. E. and A. D. Day, 1978. Use of Irrigation in Reclamation in Dry Regions. Madison, WI.

Romney, E. M., A. Wallace, and R. B. Hunter, 1980. The Pulse Hypothesis in the Establishment Artemisia Seedlings at Pahute Mesa, Nevada. Las Vegas, NV.

Trw Environmental Safety Systems, Inc., 1999. Reclamation Feasibility Studies at Yucca Mountain, Nevada. Las Vegas, NV.

USDA, see U.S. Department of Agriculture.

U.S. Department of Agriculture Forest Service, 1979. User Guide to Soils. General Technical Report INT-68. Ogden, UT.

Vasek, F. C., 1980. Early Successional Stages in Mojave Desert Scrub Vegetation.

Vasek, F. C., H. B. Johnson, and D. H. Eslinger, 1975b. Effects of Pipeline Construction on Creosote Bush Scrub Vegetation of The Mojave Desert.

Vasek, F. C., H. B. Johnson, and G. D. Brum, 1975a. Effects of Power Transmission Lines on Vegetation of the Mojave Desert.

Wallace A., E. M. Romney, and R. B. Hunter, 1980. The Challenge of a Desert: Revegetation of Disturbed Desert Lands. 
Wallace, A. and E. M. Romney, 1972. Radioecology and Ecophysiology of Desert Plants at the Nevada Test Site. USAEC Report TID-25954. Las Vegas, NV.

Webb, R. H., and H. G. Wilshire, 1980. Recovery of Soils and Vegetation in a Mojave Desert Ghost Town, Nevada. Las Vegas, NV.

Winkel, V. K. and J. L. Boone, 1999. Effects of Irrigation on Emergence and Survival of Native Plant Seedlings at Yucca Mountain, Nevada. B00000000-01717-5700-00080 Rev 00. Las Vegas, NV.

Winkel, V. K., K. W. Blomquist, J. P. Angerer, M. W. Fariss, and W. K. Ostler, 1999. Reclamation Feasibility Studies at Yucca Mountain, Nevada: 1992-1995. B00000000-01717-5700-00003 Rev 00. Las Vegas, NV. 
92-Acre Area and CAU 111 CADD/CAP

Section: Library Distribution List

Revision: 1

Date: November 2010

\section{LIBRARY DISTRIBUTION LIST}


92-Acre Area and CAU 111 CADD/CAP

Section: Library Distribution List

Revision: 1

Date: November 2010

THIS PAGE INTENTIONALLY LEFT BLANK 


\section{LIBRARY DISTRIBUTION LIST}

U.S. Department of Energy

National Nuclear Security Administration

Nevada Site Office

Technical Library

P.O. Box 98518, M/S 505

Las Vegas, NV 89193-8518

U.S. Department of Energy

Office of Scientific and Technical Information

P.O. Box 62

Oak Ridge, TN 37831-0062

Southern Nevada Public Reading Facility

c/o Nuclear Testing Archive

P.O. Box 98521, M/S 400

Las Vegas, NV 89193-8521

Manager, Northern Nevada FFACO

Public Reading Facility

c/o Nevada State Library \& Archives

Carson City, NV 89701-4285
1 (Uncontrolled, electronic copy)

1 (Uncontrolled, electronic copy)

2 (Uncontrolled, electronic copies)

1 (Uncontrolled, electronic copy) 
92-Acre Area and CAU 111 CADD/CAP

Section: Library Distribution List

Revision: 1

Date: November 2010

THIS PAGE INTENTIONALLY LEFT BLANK 